
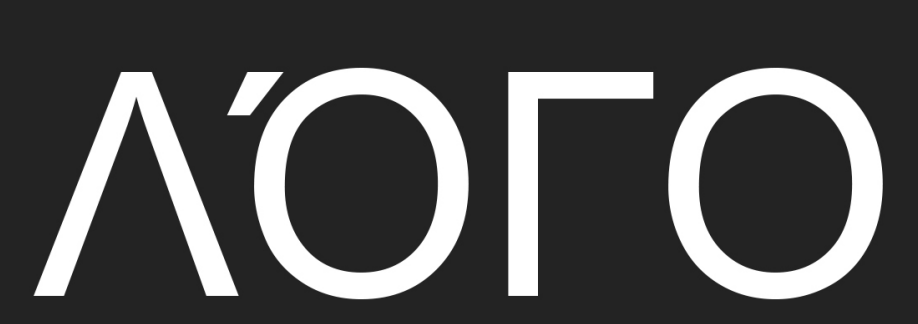

COLLECTION OF SCIENTIFIC PAPERS

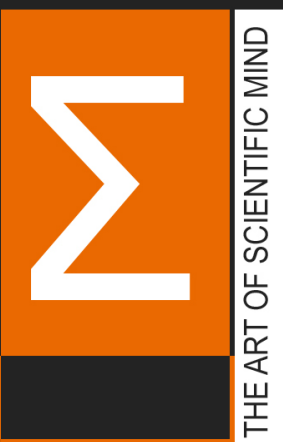

WITH PROCEEDINGS OF THE INTERNATIONAL SCIENTIFIC AND PRACTICAL CONFERENCE

\title{
SCIENTIFIC DISCOVERIES: PROJECTS, STRATEGIES AND DEVELOPMENT
}

OCTOBER 25, 2019 • EDINBURGH, SCOTLAND, UK 叉

\section{VOLUME 2}

DOI 10.36074/25.10.2019.v2 ISBN 978-617-7171-83-5

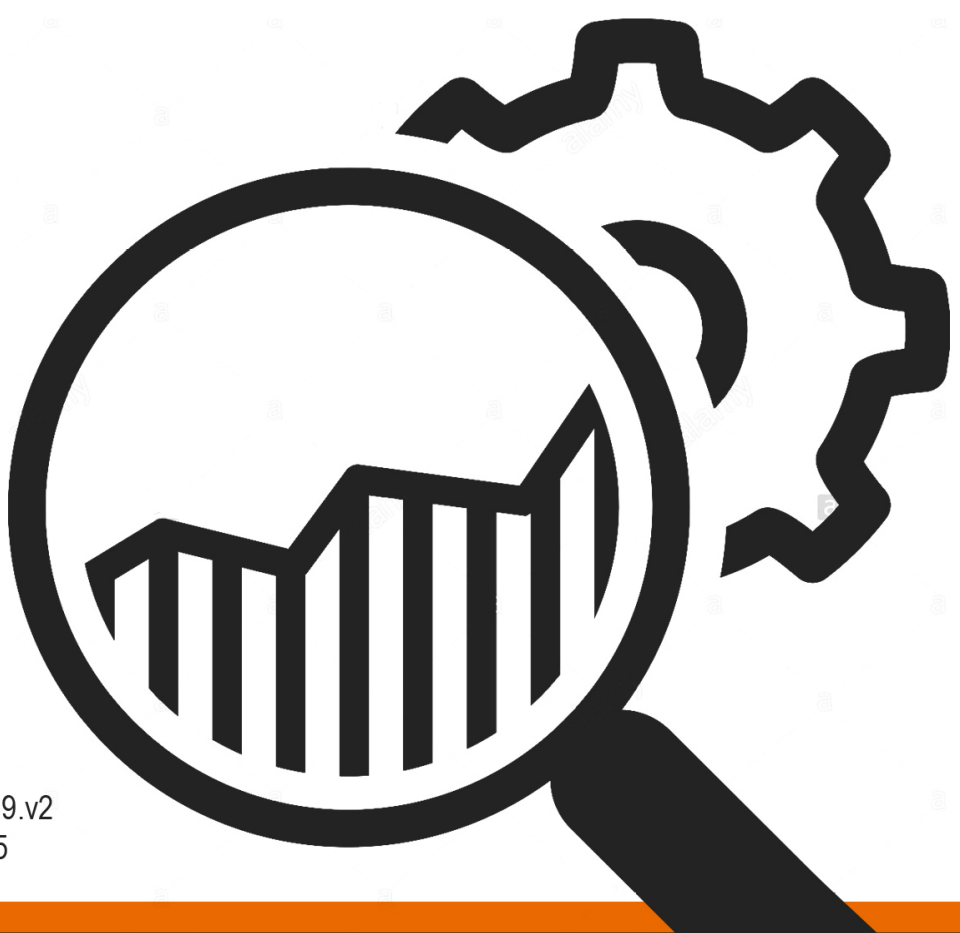



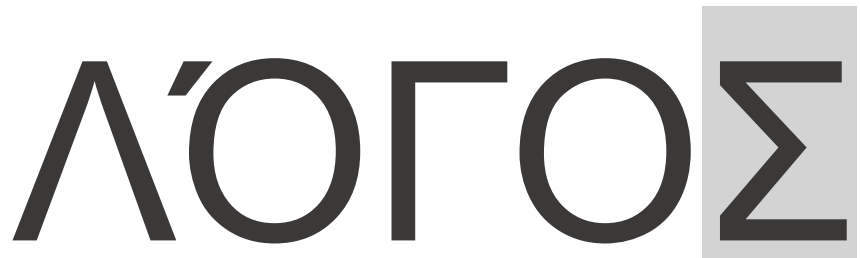

COLLECTION OF SCIENTIFIC PAPERS

WITH PROCEEDINGS OF THE INTERNATIONAL SCIENTIFIC AND PRACTICAL CONFERENCE

«SCIENTIFIC DISCOVERIES: PROJECTS, STRATEGIES AND DEVELOPMENT»

OCTOBER 25, 2019

\section{VOLUME 2}

Edinburgh • Scotland, UK 
S 30

Chairman of the Organizing Committee: Holdenblat $M$.

Responsible for the layout: Kazmina N.

Responsible designer: Bondarenko I.

S 30 Scientific discoveries: projects, strategies and development: Collection of scientific papers «^ОГО $\Sigma$ » with Proceedings of the International Scientific and Practical Conference (Vol. 2), October 25, 2019. Edinburgh, UK: European Scientific Platform.

ISBN 978-617-7171-83-5

DOI 10.36074/25.05.2019.v2

Papers of participants of the International Multidisciplinary Scientific and Practical Conference «Scientific discoveries: projects, strategies and development», held in Edinburgh, October 25, 2019, are presented in the collection of scientific papers.

The conference is included in the catalog of International Scientific Conferences, approved by ResearchBib and certified by Euro Science Certification Group (SCC-2000).

Conference proceedings are publicly available under terms of the Creative Commons Attribution 4.0 International License (CC BY 4.0).

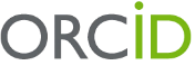

Connecting Research and Researchers

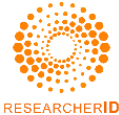

RESEARCHERID
Bibliographic descriptions of the conference proceedings are available for indexation by ORCID, Publons, Google Scholar, ets.

(C) Participants of the conference, 2019 


\section{SECTION VI. \\ MEDICINE}

\section{CONTENT}

ACTION OF ELECTROMAGNETIC FIELDS OF DIFFERENT SPECTRAL RANGES OF FREQUENCIES GENERATED IN PRODUCTION ENVIRONMENT WHEN USING MODERN TECHNOLOGICAL PROCESSES IN MACHINE-BUILDING INDUSTRY ENTERPRISES

Research group:

Dreval M., Goncharenko V., Gevorgyan S.

AUTOIMMUNE THYROIDITIS: PREVALENCE, INCIDENCE, FACTORS INFLUENCING INCIDENCE

Salun 0.

FEATURES OF PSYCHOLOGY OF LONELINESS AMONG YOUNG PEOPLE

Fadieieva A., Valentieva A.

HYGIENIC ASPECTS OF HEALTHY FOOD OF MEDICAL STUDENTS Stoian A., Hordiienko P.

MENTAL CONDITION OF FAMILIES OF PATIENTS WITH DEMENTIA Research group:

Kozhyna H., Zelenska K., Kaploukh O.

MODERN APPROACHES TO THE PSYCHOTHERAPEUTIC CORRECTION OF ORGANIC AFFECTIVE DISORDERS: CLINICAL VIEW, PSYCHOTHERAPY AND REHABILITATION

Strelnikova I.

OCCUPATIONAL MORBIDITY RESEARCH AT PUBLIC JOINTSTOCK COMPANY SUMY ENGINEERING SCIENTIFICPRODUCTION ASSOCIATION

Research group:

Dreval M., Fadieieva A., Valentieva A.

PREVALENCE OF TOOTH FORMATION DISORDERS (TFD) AMONG CHILDREN - INHABITANTS OF DIFFERENT REGIONS OF UKRAINE

Research group:

Liubarets S., Shapovalova H., Savychuk O.

ROLE OF THE COMPUTER CAPILLAROSCOPY IN THE ASSESSMENT OF EFFICIENCY OF THE INFERIOR TURBINATE 
4 • Scientific discoveries: projects, strategies and development $\bullet$ Volume 2

REDUCTION IN PATIENTS WITH RHINITIS MEDICAMENTOSA

Research group:

Shushlyapina N., Lupyr A., Cherniakova A.

THE LEVELS OF ANXIETY IN INTERNALLY DISPLACED PERSONS IN MODERN CONDITIONS

Research group:

Kozhyna H., Zelenska K., Kraskovska T.

TRADITIONAL AND MINIMALLY INVASIVE OPERATIVE METHODS OF TREATMENT OF PERFORATED GASTRODUODENAL ULCERS

Lisova Ye.

АСПЕКТИ ПОЄДНАНОЇ ХІМІОТЕРАПІЇ І ОНКОВІРОТЕРАПІЇ У ХВОРИХ З ТРИЧІ НЕГАТИВНИМ РАКОМ МОЛОЧНОЇ ЗАЛОЗИ Александрова К., Журавльова П.

ВПЛИВ СЕЛЕКТИВНОЇ ДЕКОНТАМІНАЦІЇ ШЛУНКОВОКИШКОВОГО ТРАКТУ НА ВИЖИВАНІСТЬ У ПАЦІЕНТІВ, ЯКІ ПЕРЕБУВАЮТЬ У ВІДДІЛЕННЯХ РЕАНІМАЦІЇ ТА ІНТЕНСИВНОЇ ТЕРАПІї

Александрова К., Журавльова П.

ДОСЛІДЖЕННЯ ВПЛИВУ БАГАТОКОМПОНЕНТНИХ ОРГАНІЧНИХ СУМІШЕЙ НА ОСНОВІ ГЛІКОЛІВ НА СТАН МЕТАБОЛІЧНИХ ПРОЦЕСІВ У ПРАЦІВНИКІВ ВО ККАПРОЛАКТАМ» ІНТЕГРАТИВНИМ МЕТОДОМ БІОХЕМІЛЮМІНЕСЦЕНЦІЇ

Сіренко О.В., Кучеренко Е.О.

ГАДЖЕТИ: КОРИСТЬ ЧИ ШКОДА?

Науково-дослідна група:

Коробчанський В.О., Нестеренко В.Г., Каднай О.С.

ГЛУТАМАТ НАТРІЮ ЯК ХАРЧОВА ДОБАВКА І ІЇ ВПЛИВ НА ЗДОРОВ'Я

Науково-дослідна група:

Волков І.І., Косілова О.Ю., Кателевська Н.М.

ОСОБЛИВОСТІ РОЗВИТКУ СИНДРОМУ ЕМОЦІЙНОГО ВИГОРАННЯ У ПРАЦІВНИКІВ ІНФЕКЦІИНИХ ЛІКАРЕНЬ Науково-дослідна група:

Кателевська Н.М., Дяченко І.О., Пелих І.М.

ОЦІНКА РІВНЮ ІНТЕРНЕТ-ЗАЛЕЖНОСТІ СТУДЕНТІВ ХАРКІВСЬКОГО НАЦІОНАЛЬНОГО МЕДИЧНОГО УНІВЕРСИТЕТУ Науково-дослідна група:

Герасименко О.І., Кателевська Н.М., Богачова О.С. 
ПРИНЦИПИ ЛІКУВАННЯ ГРИБКОВИХ УРАЖЕНЬ СЛИЗОВОЇ ОБОЛОНКИ ПОРОЖНИНИ РОТА У ДІТЕЙ 3 ГОСТРИМИ ФОРМАМИ ЛЕЙКЕМІЙ

Науково-дослідна група:

Легенчук О.В., Мозгова О.М., Воєвода О.О.

ПСИХО-ЕМОЦІЙНИЙ СТАН ПАЦІЄНТІВ-ПІДЛІТКІВ З ЦУКРОВИМ ДІАБЕТОМ I ТИПУ

Сухарєва Л.П., Кателевська Н.М.

\section{SECTION VII. PHARMACY}

ОПЫТ И ПЕРСПЕКТИВЫ ИСПОЛЬЗОВАНИЯ ЛЕКАРСТВЕННЫХ РАСТЕНИЙ ДЛЯ ЛЕЧЕНИЯ ИШЕМИЧЕСКОЙ БОЛЕЗНИ СЕРДЦА Научно-исследовательская группа:

Столетов Ю.В., Куценко Т.А., Уланова В.А., Белик Г.В.

\section{SECTION VIII.}

PSYCHOLOGY AND SOCIOLOGY

NEUROBIOLOGY OF POSTTRAUMATIC STRESS DISORDER Kyselova A., Chernishova E.

TENDENCIES OF EDUCATION DEVELOPMENT IN UKRAINE Yashnyk S.

ПСИХОЛОГІЧНИЙ СУПРОВІД ТВОРЧО-ОБДАРОВАНИХ ПІДЛІТКІВ В УМОВАХ РЕКРЕАЦІИНОГО ЗАКЛАДУ

Грек О.М.

ПСИХОЛОГИЧЕСКИЕ ОСОБЕННОСТИ ФОРМИРОВАНИЯ СОЦИАЛЬНО АДАПТИРОВАННОЙ АКТИВНОЙ ГАРМОНИЧНО РАЗВИТОЙ ЛИЧНОСТИ НА ПРИМЕРЕ СТАРШЕКЛАССНИКОВ Кернас А.В., Максимихина О.В.

ТЕОРЕТИКО-МЕТОДОЛОГІЧНИЙ АНАЛІЗ МЕТОДІВ АКТИВІЗАЦІЇ МИСЛЕННЯ СТУДЕНТІВ В ПРОЦЕСІ НАВЧАЛЬНОЇ ДІЯЛЬНОСТІ У 3BO

Бужинська С.М., Соколова В. 68

ХУДОЖНЯ ЛІТЕРАТУРА ЯК ЗАСІБ ОПТИМІЗАЦІЇ АДАПТАЦІЇ ВІИСЬКОВОСЛУЖБОВЦІВ ДО МИРНИХ УМОВ Казьмірук A.B. 
6 • Scientific discoveries: projects, strategies and development $\bullet$ Volume 2

\section{SECTION IX. \\ SOCIAL COMMUNICATION AND CULTUROLOGY}

THE ESSENCE OF THE POSTER AND FEATURES OF ITS COMPOSITE CONSTRUCTION AS A CARRIER OF SOCIALLY SIGNIFICANT INFORMATION

Ilchuk N.V.

ВПЛИВ КОМУНІКАЦІЙНИХ ВЛАСТИВОСТЕЙ НА БЕЗПЕКУ ЖИТТЄДІЯЛЬНОСТІ ЛЮДИНИ

Самохіна Є.А., Левченко І.В.

НАРОДНА ПІСНЯ ЯК КУЛЬТУРНИЙ ІДЕНТИФІКАТОР НАЦІЇ

Шершова Т.В.

\section{SECTION X. \\ PEDAGOGY}

BLENDED LEARNING IN ESP TEACHING

Nikitina $\mathbf{N}$.

FORMATION OF COMMUNICATIVE COMPETENCES IN THE PROFESSIONAL TRAINING PROCESS OF STUDENTS IN HIGHER EDUCATIONAL ESTABLISHMENTS

Antonivska M.

SMART-СЕРЕДОВИЩЕ ЯК СКЛАДОВА НАВЧАННЯ У ВНЗ

Лук'янова Ю.М., Комарь В.І.

IMPLEMENTATION OF THE CONCEPTUAL FOUNDATIONS OF MUSICAL EDUCATION OF PRIMARY SCHOOL CHILDREN BY MUSICAL FOLKLORE

Tsuranova O., Andreev N.

АКТУАЛЬНІ ПРОБЛЕМИ ВИЗНАЧЕННЯ ПОНЯТТЯ «КРАЄЗНАВЧА КОМПЕТЕНТІСТЬ» У ПЕДАГОГІЧНІЙ ЛІТЕРАТУРІ

Дубель І.М.

ВАЖЛИВІСТЬ ВОЛОДІННЯ ІНОЗЕМНОЮ МОВОЮ НА ШЛЯХУ ДО ЄВРОІНТЕГРАЦІЇ

Комарь В.І., Лук'янова Ю.М.

ДО ОНОВЛЕННЯ КОНЦЕПТУАЛЬНИХ ЗАСАД СЕРЕДНЬОЇ ОСВІТИ: РАЦІОГУМАНІСТИЧНА ПАРАДИГМА

Дічек Н.П. 
МІСЦЕ ТА РОЛЬ ПРОФІЛЬНОГО НАВЧАННЯ СТАРШОКЛАСНИКІВ У РОЗВИТКУ СУЧАСНИХ ЗАГАЛЬНООСВІТНІХ ШКІЛ

Загородня А.A.

ОСОБЛИВОСТІ ВИКЛАДАННЯ АНГЛІЙСЬКОЇ МОВИ ПРОФЕСІЙНОГО СПРЯМУВАННЯ КУРСАНТІВ І ПРАЦІВНИКІВ ОРГАНІВ ВНУТРІШНІХ СПРАВ (НА МАТЕРІАЛІ АНГЛІЙСЬКОЇ МОВИ)

Болкарьова О.В.

РЕЗУЛЬТАТИ ПЕДАГОГІЧНОГО ЕКСПЕРИМЕНТУ ПО ВПРОВАДЖЕННЮ МОДЕЛІ ФОРМУВАННЯ ГОТОВНОСТІ МАЙБУТНІХ ОФІЦЕРІВ НАЦІОНАЛЬНОЇ ГВАРДІЇ УКРАЇНИ ДО ВИКОНАННЯ ЗАВДАНЬ ЗА ПРИЗНАЧЕННЯМ

Хацаюк О.В., Курок О.І.

СТРУКТУРА МОТИВАЦІЙНОЇ СФЕРИ ЛІНГВОСАМООСВІТИ МАЙБУТНІХ УЧИТЕЛІВ ІНОЗЕМНИХ МОВ Шумський О.Л.

О ФОРМИРОВАНИИ КОММУНИКАТИВНО-РЕЧЕВЫХ УМЕНИЙ УЧЕНИКОВ НАЧАЛЬНЫХ КЛАССОВ

Сокаль М.А.

ОСОБЛИВОСТІ АНСАМБЛЕВОЇ ФОРМИ ВИКОНАВСТВА

Шумська О.О., Третецька М.В.

ПЕДАГОГІЧНІ УМОВИ ФОРМУВАННЯ БАЗОВИХ КОМПЕТЕНТНОСТЕЙ МАЙБУТНІХ СОЦІАЛЬНИХ ПРАЦІВНИКІВ У ПРОЦЕСІ ФАХОВОЇ ПІДГОТОВКИ

Стрельбицька С.М.

ПИТАННЯ ПРОФІЛЬНОГО НАВЧАННЯ У 90-ТИХ РОКАХ ХХ СТОЛІТТЯ

Загородня А.A.

ПІДГОТОВКА ВЧИТЕЛЯ АНГЛІЙСЬКОЇ МОВИ ДО НАВЧАННЯ ДІТЕЙ ДОШКІЛЬНОГО ВІКУ

Прохорчук В.А.

ПІДГОТОВКА ВЧИТЕЛЯ ДО РЕАЛІЗАЦІЇ КОМПЕТЕНТНІСНО ОРІЄНТОВАНОГО НАВЧАННЯ: СТАН ТА ПЕРСПЕКТИВИ

Левченко Ф.Г.

ПІДГОТОВКА МАЙБУТНІХ ВЧИТЕЛІВ ДО СУБ'ЄКТ-СУБ'ЄКТНОЇ ВЗАЄМОДІЇ З ДІТЬМИ МОЛОДШОГО ШКІЛЬНОГО ВІКУ

Блудова Ю.О., Єдименченко Ю.М. 
8 - Scientific discoveries: projects, strategies and development $\bullet$ Volume 2

ПІДГОТОВКА МАЙБУТНІХ ВЧИТЕЛІВ ДО ФОРМУВАННЯ ЕКОЛОГІЧНОЇ ГРАМОТНОСТІ МОЛОДШИХ ШКОЛЯРІВ У ПОЗАКЛАСНІЙ РОБОТІ

Толмачова І.М., Бєлкіна І.В.

ПРОПЕДЕВТИЧЕСКОЕ ИЗУЧЕНИЕ КАТЕГОРИЙ ТЕКСТА

Кон О.O.

ПСИХОЛОГІЧНІ АСПЕКТИ ВИКОРИСТАННЯ ІНФОРМАЦІЙНОКОМУНІКАЦІЙНИХ ТЕХНОЛОГІЙ В ОСВІТНЬОМУ ПРОСТОРІ

Тищенко М.А.

РЕАЛІЗАЦІЯ ТЕХНОЛОГІЇ ВRING YOUR OWN DEVICE HA ПРАКТИЧНИХ ЗАНЯТТЯХ 3 «ПРАКТИЧНОЇ ГРАМАТИКИ АНГЛІЙСЬКОї МОВИ»

Гурський І.Ю.

РОЗВИТОК МОВЛЕННЕВИХ КОМПЕТЕНЦІЙ У ПРОЦЕСІ ВИВЧЕННЯ ІНОЗЕМНОÏ МОВИ ЗА ПРОФЕСІЙНИМ СПРЯМУВАННЯМ

Демченко Н.C.

РОЛЬ ПЕДАГОГІЧНОЇ ПРАКТИКИ У ПІДГОТОВЦІ МАЙБУТНЬОГО ВЧИТЕЛЯ

Євтух М.Б.

САМОСТІЙНА РОБОТА У ПРОФЕСІЙНОМУ СТАНОВЛЕННІ МАЙБУТНЬОГО ВЧИТЕЛЯ МУЗИЧНОГО МИСТЕЦТВА

Корчагіна Г.С.

СПЕЦИФІКА ЗАСТОСУВАННЯ ІНФОРМАЦІЙНОКОМУНІКАЦІЙНИХ ТЕХНОЛОГІЙ ПРИ ОРГАНІЗАЦІЇ ОСВІТНЬОГО ПРОЦЕСУ

Корєхов А.O.

ФОРМУВАННЯ ЛЕКСИКО-НАРОДОЗНАВЧОЇ КОМПЕТЕНТНОСТІ МАЙБУТНЬОГО ВЧИТЕЛЯ ПОЧАТКОВОЇ ШКОЛИ

Гуськова А.B. 


\section{SECTION VI. \\ MEDICINE}

DOI 10.36074/25.10.2019.v2.01

\section{ACTION OF ELECTROMAGNETIC FIELDS OF DIFFERENT SPECTRAL RANGES OF FREQUENCIES GENERATED IN PRODUCTION ENVIRONMENT WHEN USING MODERN TECHNOLOGICAL PROCESSES IN MACHINE-BUILDING INDUSTRY ENTERPRISES}

RESEARCH GROUP:

Mariyana Dreval

Assistant Professor

Kharkiv National Medical University

Valeria Goncharenko

Student of 2nd medical faculty

Kharkiv National Medical University

Sofia Gevorgyan

Student of 2nd medical faculty Kharkiv National Medical University

UKRAINE

Introduction: The current problem that needs to be solved is the effect of adverse production factors on workers, which, when significant excesses during the execution of certain technological processes, can lead to occupational disease. Therefore, it is important to improve the regulatory framework and the development of preventive measures to protect the health of workers.

Relevance: The incidence of occupational diseases, high incidence rates with temporary disability among workers in the engineering industry, of course, depends on the presence of a complex of harmful factors that operate in the workplace when performing basic technological operations. The emergence of pathological conditions is facilitated, first of all, by the low level of development of production technologies themselves. In this regard, particularly relevant are clinical and epidemiological studies of working conditions and health of workers in the engineering industry.

Objective: Improve the regulatory framework and develop a strategy for preventive measures to protect the health of workers in the engineering industry. Materials and methods: Widespread use in industry, science and technology of technological processes using equipment that is the source of pulsed electromagnetic fields (IEMP), is accompanied by a constant increase in the number of workers and engineering staff who will be engaged in its operation and will be affected by the designated factor. Hygienic studies have revealed the main sources of magnetic fields. Thus, during the operation of contact welding machines in the workplace of the electric welder are formed IMP, the sources of which were 
elements of the welding circuit (welding electrodes, current supply rails, consoles, etc.) and welding products. In order to determine the duration of exposure to the body of working IMP, photomicronometric observations were made. The average duration of irradiation of electric welders during the change is $16.4-60.2 \%$ of working time and depends on the type and volume of welding work, as well as the type of equipment. The types of contact welding machines surveyed in most cases form IMP service personnel with a intensity of $0.7-30 \mathrm{kA} / \mathrm{m}$ with a pulse duration of $0.005-0.8 \mathrm{~s}$ and a repetition rate of $0.5-10 \mathrm{~s}$. Clinical studies are based on the results of a clinical examination of workers working with contact welding equipment at mechanical engineering enterprises (324 persons in the main group are electric welders). Analyzing the data, it was found that neurological complaints were made by $57 \%$ of the surveyed persons in the main group. The most numerous complaints of persons in the main group were mainly those characteristic of functional disorders of the nervous system. Thus, $40 \%$ of the surveyed noted general weakness, $25 \%$ headache mainly in the temporal-frontal areas. Increased irritability was noted by $35 \%$ of the surveyed, difficulty falling asleep with awakening at night and lack of feeling of rest after sleeping - 15\%, and "darkening in the eyes" when changing the position of the body $-7 \%$. Objective examination of electric welders draws attention to the phenomenon of irritation in the motor analyzer, as well as the reduction of abdominal reflexes, which are closed not only in the spinal cord, but also in suprasegmental levels. On the part of the blood of the main group, there were various shifts in the number of leukocytes in the peripheral blood.

Conclusions: Conducted hygienic studies of working conditions of workers in production conditions showed that at workplaces when performing work using technological processes, where electromagnetic fields are generated in the work area, levels that exceed the maximum permissible sources according to the document "State norms and rules" are recorded when working with sources of electromagnetic fields "DSNiP 3.3.6-096-2002.

Despite the vague nature of the pathologists found in electric welders, in our opinion, their work should be classified as so-called "harmful" ones, as well as the question of introducing preventive and periodic examinations of working on contact welding machines. This substantiates the relevance of research aimed at identifying the possibility of preventing diseases of professional etiology and developing measures for their prevention.

\section{AUTOIMMUNE THYROIDITIS: PREVALENCE, INCIDENCE, FACTORS INFLUENCING INCIDENCE}

Olga Salun

Assistant, Faculty of Medicine, Department of Family Medicine-General Practice Kharkiv National University by N.V. Karazin

UKRAINE

Autoimmune disease of the thyroid gland (AID), a common organ-specific autoimmune disease, is observed mainly in women aged 30-50 years. Thyroid autoimmunity can cause several forms of thyroiditis, ranging from hypothyroidism 
(Hashimoto's thyroiditis) and ending with hyperthyroidism (Graves' disease). The prevalence of autoimmune mediated hypothyroidism is about 0.8 per 100 , with $95 \%$ women. Graves' disease is about one-tenth more common than hypothyroidism, and is more common in young people. Both of these disorders have many common immunological features, and the disease can move from one state to another as the autoimmune process changes. [1]

According to modern concepts, AIT is a complex polygenic organ-specific disease whose development is caused by exogenous, endogenous and genetic factors [2]. Among the external factors that cause the development of AIT, a significant role is played by excess iodine. It is known that in high-iodine regions, the incidence of AIT is much higher (for example, in Japan), and in countries where iodine deficiency has been actively combated, the incidence of AIT has increased (for example, in Japan, Greece) [2]. Among endogenous factors, attention is drawn to acute respiratory viral diseases, chronic diseases of the nasopharynx. Recent studies have shown that gene mutations, including regulatory genes, cause the development of thyreopathies, including AIT [2]. To date, there is no doubt that AIT is a genetically driven disease. Confirmation of this thesis is the results of long-term observations of thousands of mono- and dizygotic twins in many countries of the world [27-30]. Recent studies have found that chromosomes 2 (2q33), 6 (6p21), 8 (8q24), 12 (12q22) and 13 (13q32) have loci associated with AIT. An important role in the development of AIT is also played by the cytotoxic T-lymphocyte associated 4 molecule (TLA) inhibitor genes and PTPN22 (Protein tyrosine phosphatase, nonreceptor type 22). The role of genetic factors is evidenced by the association of AIT with HLA system antigens. AIT is matched with the genes NLA-B8, NLA-DR3 and NLDR5; hypertrophic form - with the HLA-DR5 genes, atrophic - with the HLA-DR3 and HLA-B8 genes. The marker of the most significant hereditary risk of developing AIT is HLA DQw7. Specific clones of T lymphocytes capable of interacting with their own thyroid antigens may also be inherited [2]. Disorders of lymphocyte apoptosis as a factor that causes the development of autoimmune diseases of the thyroid gland attach great importance. It was found that in AIT the proportion of thyrocytes in the state of apoptosis exceeds $30 \%$, while in diffusely non-toxic goiter it does not exceed $1 \%$. An analysis of the literature has shown that information on the real incidence of AIT is rather scanty and controversial. Talking about the exact prevalence of AIT itself is not possible, since the independent clinical problem in modern foreign scientific literature is hardly discussed, only the most important result is evaluated - hypothyroidism [2,3]. However, this pathology is considered separately by domestic researchers. At the same time, there is quite a lot of information about the prevalence in the population of carriers of antibodies to thyroid tissue and the frequency of hypothyroidism. However, according to the available data, from 3 to $20 \%$ of the world population now suffer from AIT, which is the cause of the development of $70-80 \%$ of all cases of primary hypothyroidism $[3,5]$. In various countries, AIT occurs with a frequency of 0.1 to $1.2 \%$ in children and 6 to $11 \%$ in the adult population [2].

The leading thyroidologists in the world have noted a steady increase in the incidence of thyreopathy [1-4]. In Ukraine, as of January 1, 2011, it is $46.67 \%$ [1]. The reasons are the deterioration of the ecological situation, the increase of stressful situations of sociogenic nature, the improvement of diagnostics. Today, this problem is becoming more relevant and needs further research. In the group of organ-specific autoimmune diseases of the thyroid gland (thyroid), the most 
common is chronic autoimmune thyroiditis (AIT) [2]. The literature data indicate an increase in the incidence of AIT. For example, in Ukraine over the last 10 years it has increased by $68 \%$, and in terms of per 100 thousand population - by $82 \%$. The prevalence of AIT ranges from 0.1 to $1.2 \%$ in children and $6-11 \%$ in women over 60 years of age. Among working-age people, AIT is 4-8 times more likely to occur in women than in men. Recently, there has been a trend towards an increase in the incidence in the younger age groups. According to Watanabe (2002), the incidence of clinically expressed forms of AIT is $1 \%$. Subclinical thyroiditis and circulating antibodies (AT) to thyroperoxidase (TPO) are found in $10-15 \%$ of practically healthy euthyroid individuals [2].

Autoimmune thyroiditis can occur as an independent disease, or induce diseases such as type 2 diabetes, malignant thyroid cancer, adenomas. AIT, occurring in girls of puberty, increases the risk of infertility, and adolescents with this disease are prone to obesity.

From a biological point of view, such a rapid increase in the number of people with thyroid Hashimoto cannot be explained only by inherited changes in our genes, since it takes at least two generations to acquire and transmit gene mutations. Science has found that problems caused by our environment can really cause Hashimoto. Such problems can be attributed to changes in the purity of our environment, evolutionarily speaking, we have spent much of our human history struggling with the microorganisms that have tried to penetrate our bodies. Our immune system has evolved with our defense needs for tens of thousands of years, but in the last century, our environment has become increasingly hygienic, and our immune system has suddenly been left without an invader to fight. As a result, we have more allergies and autoimmune diseases [3,4]. Excess dietary iodine, which can worsen Hashimoto's in people with a genetic predisposition, but at the same time iodine helps people with Hashimoto's reduce goiter (thyroid enlargement) [5]. lodine controls the production of reactive oxygen species (ROS) in thyroid cells. Insufficient dietary intake of selenium. Several studies have touched upon this topic with greater or lesser success, but there is evidence that selenium, in combination with inositol, may be useful for people with low thyroid activity, at least to reduce the level of antibodies directed at the destruction of the thyroid gland [6]. Some anticancer drugs or drugs for multiple sclerosis, recurrent and / or chronic infections, mainly with hepatitis $C$ or a subset of herpes virus, but also with some bacterial infections. This causes prolonged inflammation, which activates many components of our immune system, including the part responsible for the emergence of autoimmunity $[7,8]$. Living in the vicinity of a petrochemical complex, exposure to certain synthetic pesticides, polychlorinated biphenyls (PCBs), Bisphenol-A (BFA), irradiation (accidental or for medical purposes) are related to environmental problems that may cause AIT.

Based on the above, we can draw the following conclusions:

1. This disease applies to all categories of people, from school age to people over 60, but has a peculiar pattern in women of puberty and young age.

2. The incidence has increased over the years.

3. No early diagnosis of the disease has been developed.

4. The specific cause of the disease has not been identified, many factors affect the development and complications.

5. AIT requires further study and development of early diagnosis of the disease. 


\title{
References:
}

1. Swain, M., Swain, T., \& Mohanty, B. K. (2005). Autoimmune thyroid disorders-An update. Indian journal of clinical biochemistry: IJCB, 20(1), 9-17. doi:10.1007/BF02893034.

2. Sheremet, M. I., Shidlovsky, V. O., Sidorchuk, L. P. (2014). Autoimmune thyroiditis. Current views on pathogenesis and treatment. ENDOKRYNOLOGIA, 19(3), 227-228.

3. Chervonsky, A. V. (2010). Influence of microbial environment on autoimmunity, Nature Immunology, (11), 28-35. doi:10.1038/ni.1801.

4. Kondrashova, A,, Seiskari, T,, Ilonen, J,, Knip, M. \& Hyöty, H. (2012). The 'Hygiene hypothesis' and the sharp gradient in the incidence of autoimmune and allergic diseases between Russian Karelia and Finland. APMIS. doi: https://doi.org/10.1111/apm.12023.

5. F. Aghini Lombardi, E. Fiore, M. Tonacchera, L. Antonangeli, T. Rago, M. Frigeri, A. M. Provenzale, L. Montanelli, L. Grasso, A. Pinchera, P. Vitti. (2013). The Effect of Voluntary lodine Prophylaxis in a Small Rural Community: The Pescopagano Survey 15 Years Later. The Journal of Clinical Endocrinology \& Metabolism, 98 (3), 1031-1039. https://doi.org/10.1210/jc.2012-2960.

6. Drutel, A. , Archambeaud, F. and Caron, P. (2013). Selenium and the thyroid gland: more good news for clinicians. Clin Endocrinol, (78), 155-164. doi:10.1111/cen.12066.

7. Caselli, E., Zatelli, M. C., Rizzo, R., Benedetti, S., Martorelli, D., Trasforini, G., ... Dolcetti, R. (2012). Virologic and immunologic evidence supporting an association between HHV-6 and Hashimoto's thyroiditis. PLoS pathogens, 8(10), e1002951. doi:10.1371/journal.ppat.1002951.

8. Eschler, D. C., Hasham, A., \& Tomer, Y. (2011). Cutting edge: the etiology of autoimmune thyroid diseases. Clinical reviews in allergy \& immunology, 41(2), 190-197. doi:10.1007/s12016-010-8245-8.

\section{FEATURES OF PSYCHOLOGY OF LONELINESS AMONG YOUNG PEOPLE}

\author{
RESEARCH GROUP: \\ Anastasiia Fadieieva \\ student of $2^{\text {nd }}$ medical faculty \\ Kharkiv National Medical University \\ Alina Valentieva \\ student of $2^{\text {nd }}$ medical faculty \\ Kharkiv National Medical University \\ Scientific adviser: Kateryna Zelenska \\ Ph.D., Assistant \\ Kharkiv National Medical University \\ UKRAINE
}

The question of loneliness among modern people is very relevant. It is known that the number of single people has doubled since the 1970s. Many countries are currently addressing this issue nationwide. It has even caused the emergence of a 
specialized minister of loneliness in the UK, as according to statistics, loneliness significantly reduces life expectancy.

Firstly, the main groups of people who are lonely need to be identified, usually these are the 2 main categories: young people under $35(15 \%)$ and older people after 55 (almost 60\%).

Objective: To study the causes of loneliness and anxiety among young people.

We surveyed 34 people between the ages of 18-35 years of both sexes who considered themselves lonely.

We used the following methods: directed clinical interview, anamnestic, psychodiagnostic (questionnaire proposed by J. Teylor and aimed at measuring anxiety level).

The main reasons that cause loneliness among young people are the fear of people of the opposite sex, stereotypical thinking, escaping into virtual reality, hyperbolized self-defense, which develops from excessive caution, a sense of inner conflict, thinking about the sand in the flow of people in the big city. Such feelings may arise because the metropolis can usually give a person only a lot of surface dating, and it takes a long time to find close friends. But is it possible to have long and in-depth communication with a person who has hundreds of his or her own affairs? In addition, the psychological environment of the city is quite aggressive, so most people try to wear masks and keep the limits of their own space, communication which is not only comfortable, but also empty and fuzzy. The problem is also that many young people try to compensate for their loneliness through online communication, which only aggravates the situation, as no correspondence can convey the full range of emotions of live communication.

We obtained the following results from the J. Teylor questionnaire: 4 people (11.76\%) had low anxiety (0-5 points); the average (with a tendency to low) - 16 people $(47.05 \%)$; medium (with a tendency to high) - 10 people $(29,43 \%)$; high level of anxiety - 4 people $(11,76 \%)$.

Ways of getting rid of young people will be: primary socialization, for some reason, which did not take place earlier, the educational activity, the opportunity to consult a psychologist at any time, since it is almost impossible to overcome this problem, help in understanding their problem.

As a conclusion, we can say that work on increasing loneliness in society should be carried out not only by people who have encountered this problem, but also at the national level. For this purpose it is necessary to take into account the peculiarities of age group, to provide centralized help, consultations, to give opportunities for new acquaintances and communication.

Also, lonely people have manifestations of anxiety of varying degrees of severity, so we should also pay attention to this aspect of life of people with loneliness. 


\section{HYGIENIC ASPECTS OF HEALTHY FOOD OF MEDICAL STUDENTS}

Anna Stoian

applicant for higher education of the Medical faculty Kharkiv national medical university

Polina Hordiienko applicant for higher education of the Medical faculty Kharkiv national medical university

Scientific adviser: Natalia Katelevska Ph.D. (Medicine), Associate professor of the Department of Hygiene and Ecology №1 Kharkiv national medical university

UKRAINE

Introduction. Nutrition is the main form of energy for a young student. In our time, nutrition plays an important role in maintaining the physical health of the body. Proper and rational nutrition contributes to improved performance and mental activity. Many students in the modern world consume a lot of harmful food. Malnutrition leads to chronic diseases, the emergence of pathologies in the digestive tract, and as a result - a decrease in the quality of study, level of performance, academic success. The introduction of nutrition among students is not only a necessary factor for maintaining optimal physical health, but also one of the main components of improving the level of learning.

Aim. To determine the impact of healthy eating on student youth for the development and enhancement of educational activities.

Study material. It is now proven that proper and rational nutrition has a significant impact on improving student learning. Healthy eating is a necessary factor for disease prevention, maintaining immunity, improving life, enhancing adaptation to the environment. In today's world, student youth are eating irregularly and incorrectly, at least 1-2 times a day. Student nutrition has certain characteristics that should be compared with the personal regime of the day and physical activity on the body, namely, on how well organized healthy nutrition of the student depends on the overall level of physical activity and quality of educational activity. The key to maintaining a normal physical state is to maintain a balanced diet and control the intake of essential components: carbohydrates, proteins, fats, vitamins. According to the physiological point of view, in the body of the student, nutrients - nutrients are split and absorbed into the blood. Their cleavage is the key to providing the body with the nutrients it needs to support its metabolism and meet certain energy and plastic needs.

In the XXI century. physiological theory is fundamental for determining the rational rates of need and consumption of biologically active substances for different populations, and especially for students. According to physiological theory, the organism must be secured according to energy expenditure and digestive mechanisms. Daily energy costs should be consistent with the energy value of the student's diet. There must be micronutrients in the student's daily diet. There is a 
need to properly calculate the caloric content of the diet and energy expenditure of the organism, depending on the individual characteristics: age, height, weight, physical endurance, training. It is worth noting that men typically consume up to 3,000 calories and women typically consume up to 2,600 calories per day. At the same time, it is necessary to compare the amount of rye consumption per day with energy costs, which are usually greater than the amount of calories that should be received [2].

The analysis of literary sources devoted to healthy nutrition allowed to distinguish the basic principles of healthy nutrition of student youth: 1) nutrition balance; 2) compliance of the caloric value of the diet with energy costs; 3) the distribution of food costs throughout the day, consistent with the student's daily schedule.

Also, the diet of student youth should have an anti-stress effect, to ensure optimal functioning of the nervous system, optimize fat metabolism. Eating disorders can be the basis for hypertension, excess body weight, and cardiovascular diseases, which cause the effects of reduced health and overall health. First of all, food can supply excess energy when unbalanced and poor nutrition, and is a source of lack of bioregulatory mechanisms and protective and adaptive reactions of the body. Today, the student body of today, because of stress, lack of financial resources and problems in personal life, consumes harmful food, namely: a lot of carbohydrates, fats, insufficient amount of drinking water, so there are disturbances in water-salt exchange and maintenance of electrolyte balance. Insufficiency of essential biologically active substances such as proteins, vitamins, trace elements is a prerequisite for the accumulation in the body of students of radionuclides that destroy the body. These principles make it possible to attribute healthy nutrition to the most important factor that has a direct impact on the development and improvement of learning [2].

Conclusion. Given the above, regarding the healthy diet of student youth and its impact on the overall level of education, it may be necessary to provide the necessary recommendations to maintain a healthy level of nutrition. Medical students in our world need to be a role model for the surrounding population. In today's society, students need guidance to support the principles of sound and healthy eating, which must be fully compared to the individual student's day regime, quantitative and qualitative indicators of learning and the level of daily energy costs. Modern youth should be encouraged to have a correct attitude to their state of health, the need for full correspondence between energy value and the composition of the diet, which should be enriched with nutrients. Balanced and healthy nutrition is the key to improving the academic success of student youth and further development of the modern specialist in future activities.

\section{References:}

1. Astarita, G, Langridge. J. (2013). An emerging role for metabolomics in nutrition science. J Nutrigenet Nutrigenomics, (6), 181-200. DOI: 10.1159/000354403

2. Cornelis, M. C., \& Hu, F. B. (2013). Systems Epidemiology: A New Direction in Nutrition and Metabolic Disease Research. Current nutrition reports, 2(4). DOI: 10.1007/s13668-013-0052-4. 


\section{MENTAL CONDITION OF FAMILIES OF PATIENTS WITH DEMENTIA}

RESEARCH GROUP:

Hanna Kozhyna

D.Sc. (Medicine), Professor, Head of the Department of Psychiatry, Narcology, Medical Psychology and Social Work Kharkiv National Medical University

Zelenska Kateryna Oleksiivna Ph.D. (Medicine), Associate Professor of the Department of Psychiatry, Narcology, Medical Psychology and Social Work Kharkiv National Medical University

Kaploukh Olha Mykolaivna Ph.D. student of the Department of Psychiatry, Narcology, Medical Psychology and Social Work Kharkiv National Medical University

UKRAINE

Topicality: Dementia is a disease in which the patient's cognitive and mental abilities are disturbed. It causes impairment of mental capacity, memory, ability to navigate time and space, as well as the ability to recognize people and objects. In this regard, the ability to carry out daily activities and contact with others is also gradually reduced. Among other things, the patient suffers from confused consciousness, anger, suspicion and even outbreaks of aggression. Subsequently, in addition to the cognitive impairment, physical capabilities are also affected [1].

Dementia is one of the main factors leading to the limitations of elderly people, and it is considered one of the most serious illnesses for the patient, his family and society [2].

Objective: To determine the mental state of the families of patients with dementia

Materials and Methods: We surveyed 59 families: 59 dementia patients and their families took part in the study. Patients were treated at KNP CHOR "Regional Clinical Psychiatric Hospital \# 3". The following psycho-diagnostic techniques were used in the study: "Structured Interview Scale for Determining Relation of Family Members to Sickness (Psychiatric Diagnosis) in a Relative" (VA Abramov et al., 2009), Questionnaire "Type of Attitude of Family to Psychotropic Drug Therapy" ( NB Lutova, OV Makarevich, 2011).

Results: According to the results of "Scale of a structured interview for determining the relation of family members to illness (psychiatric diagnosis) in a relative" we obtained $29(49,15 \%)$ families with adequate attitude to the illness of a beloved one, $11(18,64 \%)$ with a dramatizing attitude to the disease and 19 (32.21\%) with a negative (destructive) attitude to the disease. According to the questionnaire "Type of family attitude to therapy with psychotropic drugs": the hostile type was in $9(15.25 \%)$ families, the distracted type - $21(35.6 \%)$ families, manipulative type - 17 (28.81\%), supportive type - 12 (20.34\%). 
18 - Scientific discoveries: projects, strategies and development $\bullet$ Volume 2

Conclusions: The obtained results indicate that not all of the families are able to correctly perceive the illness of an elderly relative, so in the future we will develop a system of psychological support and correction of unwanted forms of attitude to the disease and attitude to treatment with psychotropic drugs.

\title{
References:
}

1. Shevchenko-Bitenskyi, K. V. (2019). Sotsialne funktsionuvannia patsiientiv $z$ haliutsynatornoparanoidnymy rozladamy pry zmishanykh dementsiiakh tiazhkoho stupenia vyrazhenosti [Social functioning of patients with hallucinatory-paranoid disorders in mixed dementia of severe severity]. Ukrainskyi visnyk psykhonevrolohii, (27, 3/100), 61-64.

2. Pinchuk, I. Ya., Kolodiezhnyi, O. V., Drevitska, O. O., Myshakivska, O. M. \& Zdoryk, I. F. (2017). Psykhiatrychni tsentry dennoho dohliadu - Perspektyvnyi napriam rozvytku psykhiatrychnoi dopomohy [Psychiatric Day Care Centers -A Prospective Area for the Development of Psychiatric Care]. Arkhiv psykhiatrii, (23, 1/88), 74-75.

DOI 10.36074/25.10.2019.v2.03

\section{MODERN APPROACHES TO THE PSYCHOTHERAPEUTIC CORRECTION OF ORGANIC AFFECTIVE DISORDERS: CLINICAL VIEW, PSYCHOTHERAPY AND REHABILITATION}

\author{
Iryna Strelnikova \\ Associate Professor \\ Kharkiv National Medical University
}

UKRAINE

In order to achieve this aim, in compliance with the principles of bioethics and deontology, 89 persons of both sexes, aged 22 - 49 years old, with organic affective disorders belonging to category F 06 ICD 10., were examined. The survey was conducted for clinical and psychopathological characteristics of organic affective disorders and the development of the principles of prevention and rehabilitation.

The results obtained that several number of factors are provoke the development of affective disorders in the examined patients. These factors related to residual-organic pathology combined genesis, stressors, information exposure, heavy loads, reducing social security and life standards of the most of Ukrainian people, the social tension in society, the need for quick response and decisionmaking capability, conflict in society, intrapersonal conflicts.

Target organs are the thymus, stomach, spleen and pancreas. They give a response to the occurrence of the above disease. This contributes to the launch of the complex pathogenesis of organic affective disorders. We studied and discussed the main types and clinical manifestations of organic affective disorders in detail.

The study showed that the clinical features of the structure of organic affective disorders determined the cause. Depending on etiopathogenetic factors there are following options of organic affective disorders: nosogenic, psychogenic, pharmakogenic and combined.

Was established that in the examined patients the depressive disorders, affective reaction, dysphoria, and obsessive-phobic disorders, rarely - hypomania 
fairly often. At the same time we observed the following options for depression: sadness, adynamic, hypochondriacally, anxiety and depression with depersonalization.

The level of mental stress, asthenic conditions, anxiety and depression in different groups of patients according to specific diagnostic scales, was studied in the present work. The above data have allowed developing a comprehensive system of pathogenically grounded psychotherapeutic correction of organic affective disorders.

The results showed that using of multifactorial social activities make the rehabilitation complex holistic for the patients. Using of rehabilitation complex is essential in order to achieve effective social and employment recovery in patients with organic affective disorders.

\section{References:}

1. Bittner, A, Goodwin, R. D. \& Wittchen, H. U., et al. (2004). What characteristics of primary anxiety disorders predict subsequent major depressive disorder? J Clin Psychiatry, 65(5), 618-626. DOI: 10.4088/jcp.v65n0505.

2. Fricchione, G. (2004). Generalized anxiety disorder. New Engl J Med, 351 (7), 675-682. DOI: 10.1056/NEJMcp022342.

3. Rouillon, F. (2001). Depression comorbid with anxiety or medical illness: The role of paroxetine. Int J Psychiat Clin Practice, (5), 3-10. DOI: 10.1080/136515001300225132.

\section{OCCUPATIONAL MORBIDITY RESEARCH AT PUBLIC JOINT- STOCK COMPANY SUMY ENGINEERING SCIENTIFIC- PRODUCTION ASSOCIATION}

RESEARCH GROUP:

Mariyana Dreval

Assistant Professor

Kharkiv National Medical University

Anastasiia Fadieieva

Student of 2nd medical faculty Kharkiv National Medical University

Alina Valentieva

Student of 2nd medical faculty Kharkiv National Medical University

UKRAINE

Relevance: Today, high levels of occupational morbidity persist in mechanical engineering companies, especially those that use outdated equipment. In this case, there are disturbances in the functioning of such systems as respiratory, neurosensory and musculoskeletal. 
Objective: To conduct a medical examination of the employees of Public JointStock Company Sumy Engineering Scientific-Production Association for the purpose of establishing their professional suitability or transfer to another job.

Materials and Methods: During the work 98 employees of different professions (boilers, blacksmiths, fellers, locksmiths) of different workshops and sections of Public Joint-Stock Company Sumy Engineering Scientific-Production Association were engaged.

Results: Occupational pathologies were identified in 65 individuals on the basis of a medical examination. Of these, 17 were affected by COPD stage I, and 40 were affected by COPD II. At the same time, the impairment was reported in the injured, i.e the disease was not diagnosed at the initial stage. Also, 62 people were diagnosed with sensorineural hearing loss II stage. 5 employees, III stage. 44 employees, IV stage with 13 employees. Among the affected with bronchopulmonary pathology at Public Joint-Stock Company Sumy Engineering Scientific-Production Association age distribution is as follows:

-30-39 years-2 affected;

$-40-49$ years -4 affected;

$-50-59$ years -38 affected;

-more than 60 years-14 affected.

Conclusions: In the course of the study, the level of occupational morbidity and its impact on the labor and viability of all age groups of Public Joint-Stock Company Sumy Engineering Scientific-Production Association.

DOI 10.36074/25.10.2019.v2.05

\section{PREVALENCE OF TOOTH FORMATION DISORDERS (TFD) AMONG CHILDREN - INHABITANTS OF DIFFERENT REGIONS OF UKRAINE}

ORCID ID: 0000-0002-0995-2812

RESEARCH GROUP:

associate professor of the Department of Pediatric and Preventive Dentistry Bogomolets National Medical University (NMU)

ORCID ID: 0000-0002-7240-6822

Hanna Shapovalova

assistant professor of the Department of Pediatric and Preventive Dentistry Bogomolets National Medical University (NMU)

ORCID ID: 0000-0003-1898-8208

Oleksandr Savychuk

professor of the Department of Pediatric and Preventive Dentistry Bogomolets National Medical University (NMU)

UKRAINE

Increasing the prevalence of hard tissues diseases of tooth of both carious and non-carious genesis among the pediatric population of Ukraine of all ages, including 
among the youngest segments of the population, gives this pressing medical problem also a significant social aspect $[3,4,5,8,11,13,15]$.

Resistance of hard tissues of the teeth is based on their structural full value and degree of mineralization, which in turn depends on the age of the child and the conditions of formation of its dental - jaw system (in the antenatal period and in early childhood) $[1,2,6,7,10,12]$. It is a study of the violation of the formation of hard tissues of the permanent teeth (significant caries factor, which has a stable permanent character) acquires special pathogenetic significance.

Purpose of the study: to substantiate the main directions of prevention of diseases of hard tissues of permanent teeth in children with defects of their development.

Objectives of the study: to study the prevalence and features of tooth formation disorders (TFD) in children - inhabitants of different regions of Ukraine.

Materials and methods of research. In order to study the prevalence of teeth forming disorders in children, an epidemiological survey of 2024 children aged 5 to 18 years in five regions of Ukraine was conducted: Western (I) - 254 people (12.55\%), Eastern (II) - 79 children (3.9\%), Southern (III) - 54 children (2.67\%), Northern (IV) 1470 inspected people (72,63\%), Central (V) - 167 children $(8.25 \%)$. Among the inspected there were 836 boys $(41.30 \%)$, 1188 girls $(58.70 \%)$. The average age of children examined was $12.59 \pm 2.93$ years.

The number of children for the epidemiological study was calculated on the basis of the analysis of the given statistics of the prevalence of TFD among the pediatric population in Europe and the number of infants from the total population of Ukraine in the last year before the start of the inspection.

The examinations of children were conducted at the Department of Pediatric Therapeutic Dentistry and Dental Disease Prevention of Bogomolets NMU; at the "Universum" Lyceum in Kyiv; in the Department of Radiation Endocrinology of the Pediatric Age of the Institute of Clinical Radiology of State Institution "National Research Center of the National Academy of Medical Sciences of Ukraine" and on the basis of the state institution "Children's specialized sanatorium "Source "of the Ministry of Health of Ukraine "(Truskavets, Lviv region).

Assessment of the nature of non-carious dental lesions was performed according to the International Classification of Dental Diseases (ICD-10) [9]. Among them, in accordance with the classification ICD-10, diagnosed pathology of hard tissues of the teeth belonging to the groups: "Violation of the formation of teeth" (K00.4).

For the differential diagnosis of hypoplasia and caries, the method of enamel vital coloring (Aksamit LA, 1973) and the transillumination method were used [9]. Clinical forms of SHE have been described according to the Yu classification. A. Fedorov and co-authors [9]: spotted, erosive, furrowed and mixed. The degree of molar-incisal hypomineralisation of enamel $(\mathrm{MIH})$, as a type of systemic enamel hypoplasia (SHE) was established according to the recommendations of Jalevik B. et al., 2001 [14]. The work also used epidemiological, clinical, radiological and statistical methods of study.

Research results. To study the prevalence of TFD, 1645 children with chronic diseases of various organs and systems under compensation were selected. The 
prevalence of TFD in children - inhabitants of different regions of Ukraine is presented at figure 1 .

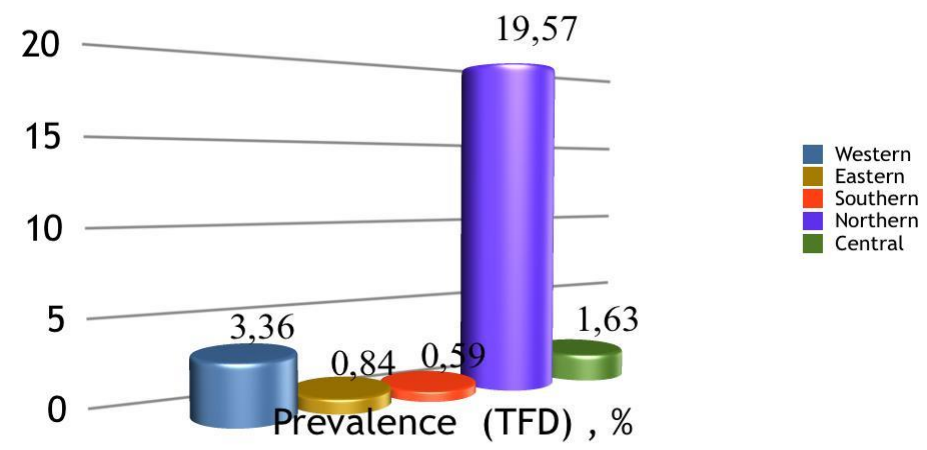

Fig. 1. The prevalence of TFD in children - inhabitants of different regions of Ukraine

According to the epidemiological study, cases of permanent tooth formation in children have been identified among residents of all regions of Ukraine. Accordingly, the prevalence of TFD among children - inhabitants of different regions of Ukraine was in the Western region - 26,77\% (68). In the Eastern and Southern Regions, the TFD incidence was slightly lower and amounted respectively to $21.52 \%$ (17 people) and $22.22 \%$ (12 people). The highest studied indicator was set among 396 children - inhabitants of the Northern region, which reached $36.30 \%$. The smallest prevalence of TFD cases was diagnosed in the inspected of residents of the Central region of Ukraine - 33 people (19.76\%).

Overall, TFD occurred in Ukraine among 647 inspected children and, accordingly, the TFD frequency averaged $31.97 \%$. Among all cases, TFD was most commonly diagnosed with an SHE of $80.22 \%$, and $\mathrm{MIH}$ was detected among $19.78 \%$ of persons.

The highest rates, both for the overall prevalence of TFD (36.30\%; 396 children) and for individual clinical forms, were diagnosed among inspected residents of the Northern Region (1091 children; group IV). Accordingly, the SHE (its chronological form) was diagnosed in 332 people, accounting for $30.43 \%$. It is worth noting that $\mathrm{MRH}$ was also detected in the children of this region, but accordingly, among the significantly smaller number of children, there are 64 people, which is $5.87 \%$.

In a inspected of children - inhabitants in the Western Region (I), where TFD was detected at a level of $26.77 \%$, where the main clinical form of TFD was SHE, which was diagnosed in 62 children, which was $24.41 \%$ of the total number of children examined (254 persons). MIH was detected among only 6 children inspected, which corresponds to $2.36 \%$.

In the Eastern (II) and Southern (III) regions, the SHE and MIH levels were slightly lower, accounting for 18.99 and $2.53 \%$ (II) and 20.37 and $1.85 \%$ (III), respectively. It was found that among the inspected residents of the Central Region (167), where the lowest percentage of children with TFD was diagnosed, $19.76 \%$ 
(33) and the lowest level of SHE was $14.97 \%$ (25). It should be noted that the prevalence of $\mathrm{MRH}$ among the inspected children - inhabitants of the Central region was not the lowest and amounted to $4.79 \%$ (8), which corresponded to the second place among the studied regions.

Conclusions. Analyzing the data obtained, we can conclude that the prevalence of TFD in SHE form was highest among children - inhabitants of the Northern Region of Ukraine (IV) with a tendency to decrease in the Western, Southern, Eastern and Central regions. The varying prevalence of TFD and SHE by region may be related to a range of factors, including the external environment, which is acted during the intra - jaw period of permanent tooth development during the first years of a child's life.

For the first time in Ukraine an epidemiological study of the prevalence of $\mathrm{MIH}$ among children - inhabitants of different regions of Ukraine was conducted. The $\mathrm{MIH}$ prevalence was found to be significantly lower in Ukraine's child population compared to the $\mathrm{MIH}$ and ranged from the highest level $-5.87 \%$ in the Northern region and to the lowest value $-1.85 \%$ among the residents of the Southern region.

Zonal tendency of decreasing $\mathrm{MIH}$ prevalence among different regions of Ukraine is revealed: Northern and Central regions with high prevalence $-5.87 \%$ and 4.79\%; Eastern and Western regions with an average level of $3.56 \%$ and $2.36 \%$; Southern region with low prevalence of $\mathrm{MIH}-1.85 \%$.

The established trends should be taken into account when drawing up regional programs for the prevention of major dental diseases.

\section{References:}

1. Булкина, Н. В., Пудовкина, Е. А. \& Захоревич, А. М. (2012). Ультрамикроскопическое исследование процессов деминерализации и реминерализации эмали зубов. Стоматология, (3), 11-14.

2. Годованець, О. І. \& Гончаренко, В. А. (2015). Особливості мінералізації емалі зубів у дітей, хворих на дифузний нетоксичий зоб. Профілактична та дитяча стоматологія, 2(13), 1417.

3. Калініченко, Ю. \& Сіротченко, Т. (2010). Взаємозв'язок та взаємовплив стоматологічного та соматичного здоров'я дітей та підлітків як сучасна медико-соціальна проблема. Здоровье ребенка, 3(24), 7-4.

4. Ковач, І. В. \& Воляк, Л. М. (2011). Строки прорізування постійних зубів у дітей із системною гіпоплазією емалі на тлі ендемічного зобу. Современная стоматология, 3(57), 92-95.

5. Лабій, Ю. А. (2016). Шляхи підвищення резистентності емалі зубів у дітей, хворих на системну гіпоплазію, що проживають в районах з різним антропогенним забрудненням (автореф. дис. ... канд. мед. наук). Івано-Франківський Національний медичний університет. Івано-Франківськ, Україна.

6. Острянко, В. І., Якубова, І. І. \& Тіньков, В.О.(2015). Дослідження складу незрілої емалі постійних зубів методом рентген-дисперсійного спектрального аналізу. Новини стоматології, 2(83), 82-88.

7. Павлова, Т. В. \& Бавыкина, Т. Ю. (2009). Сравнительная оценка минерального состава и ультрамикроструктуры тканей зуба в норме и при кариесе. Современные наукоемкие технологии, (12), 15-18.

8. Смоляр, Н. І., Безвушко, Е. В., Чухрай, Н. Л. \& Мельничук, Н. І. (2012). Профрілактична та дитяча стоматологія, 2(7), 43-45. 
9. Хоменко, Л. А., Кисельникова, Л. П., Смоляр, Н.И.& Чайковский, Ю. Б., Васильев, А. Ю., Остапко, Е. И. (2013). Терапевтическая стоматология детского возраста. Киев: ООО Книга Плюс.

10. Хоменко, Л. О., Остапко, О. І., Біденко, Н. В. \& Голубєва, І. М. (2016). Вплив навколишнього середовища на стоматологічне здоров'я дітей України. Медична наука України (Т. 12), (1-2), 51-58.

11. Хоменко, Л. О. (2007). Стоматологічне здоров'я дітей України, реальність, перспектива. Науковий вісник Національного медичного Університету імені О. О. Богомольця, (4), 1114.

12. Удод, А. А. \& Антипова, И. М. (2013). Структурно-функциональная кислотоустойчивость эмали зубов и ее прозрачность. Український стоматологічний альманах, (5), 104-105.

13. Liubarets, S. (2016). Dental status of children with the teeth formation disorders. Eureka: Health Sciences, (2), 18-24. https://doi.org/10.21303/2504-5679.2016.00089.

14. Jalevik, B, Noren, J. G., Klingberg, G. \& Barregard, L. (2001). Etiologic factors influencing the prevalence of demarcated opacities in permanent first molars in a group of Swedish children. European Journal of Oral Sciences, (109), 230-234. https://doi.org/10.1034/j.16000722.2001.00047.x.

15. Pliska, O., Opanasenko, O. \& Mozgova, O. (2018). Treatment of apical periodontitis of permanent teeth with immature roots. «Літні наукові дискусії»: Збір. наук. мат. XXI Міжн. наук.-практ. інтернет-конфр. el-conf.com.uа, 15 червня 2018 р., (Ч. 2, с. 8-11). Вінниця, Україна.

\section{ROLE OF THE COMPUTER CAPILLAROSCOPY IN THE ASSESSMENT OF EFFICIENCY OF THE INFERIOR TURBINATE REDUCTION IN PATIENTS WITH RHINITIS MEDICAMENTOSA}

RESEARCH GROUP:

Natalya Shushlyapina

$\mathrm{PhD}$, associate professor, associate professor of the

Department of Otorhinolaryngology

Kharkov National Medical Universit

Andrey Lupyr

$M D$, associate professor, associate professor of the

Department of Otorhinolaryngology

Kharkov National Medical Universit

Alexandra Cherniakova

$\mathrm{PhD}$ student of the Department of Otorhinolaryngology

Kharkov National Medical University

UKRAINE

Rhinitis medicamentosa is an urgent problem of modern otorhinolaryngology. This pathology makes up $1 \%$ of the entire ENT pathology and up to $12.5 \%$ of patients with diseases of the nasal cavity and paranasal sinuses. [1] According to 
the research of E. Mehuys et al., (2014), half of patients diagnosed with non-drug rhinitis use decongestans without doctor's prescription. This prevalence of the disease can be explained by the availability of this group of drugs for patients and the quick elimination of unpleasant symptoms after their use.

Prolonged use of vasoconstrictor drops leads to persistent hypertrophy of the inferior nasal concha, which can be eliminated only by surgery. Over the 130 years of the existence of turbinate reduction as an operation, more than 13 methods of its implementation have been proposed [2]. However, modern medicine puts forward clear requirements in the application of certain methods of surgical intervention: functionality, minimally invasiveness and the minimum duration of the rehabilitation period. [3]

Aim: to study and compare the morphofunctional state of the microcirculatory of the lower nasal concha in case of rhinitis medicamentosa after radiofrequency and laser turbinate reduction.

Materials and methods: the study included 30 patients ( 17 women and 13 men) with a diagnosis of rhinitis medicamentosa, the duration of the use of decongestants for more than 1 year. The age of patients ranged from 18 to 60 years. All patients were divided into two groups, depending on the type of surgical treatment. Group 1 - 17 patients with rhinitis medicamentosa who were made laser turbinate reduction using the "Lika-hirurg» surgical pulse-periodic semiconductor high-energy laser with a wavelength of $0.81 \square 0.03$ microns and a laser radiation power of 1 to $10 \mathrm{~W}$. The 2nd group included 15 patients with rhinitis medicamentosa who were made radiofrequency reduction of the inferior nasal concha using a high-frequency electrosurgical apparatus of the manufacturer EXHF-120 PX "Nadiya-4" (a radiosurgical scalpel in the cutting-coagulation mode with a power of 50-70 W). Assessment of the course of the postoperative period was evaluated by such criteria as: patient complaints before and after surgery, the quality of nasal breathing on the NOSE scale, instrumental and endoscopic examination of the nasal cavity, a study of the main functions of the nose with a study of the state of the local microvasculature before and after surgery. Structural changes in the microvasculature were evaluated by the results of computer capillaroscopy of the turbinates with a visual increase of 550 times (Biobase group WXH-8 1004C video capillaroscope, JOYMED TECH co., Ltd).

Results. Analysis of the obtained research data demonstrated that subjective improvement of nasal breathing, a significant decrease in the volume of the inferior nasal concha during an objective examination, and recovery of the mucous membrane occurred faster during radiofrequency turbinate reduction. This was confirmed by the study of microvasculature during capillaroscopy. The effectiveness of vaporization was confirmed by a change in the deep layers of the mucous membrane of blood vessels, especially venules, the middle and outer shells of blood vessels were "sealed", fragmentation of elastic fibers was noted. With laser turbinate reduction, with an increase in the laser radiation power, an increase in the depth of destruction occurred periodically up to the bone with an increase in the diameter of the crater and the zone of lateral damage.

Thus, among the considered types of methods for minimally invasive interventions on the inferior nasal turbinates with rhinitis medicamentosa, the 
method of monopolar radiofrequency reduction of the lower turbinates is more effective and less traumatic.

Video capillaroscopy is an accessible and informative method for diagnosing the state of microcirculation of the nasal cavity, which must be used to assess the quality of surgical interventions on the lower nasal concha. It is necessary to continue research in this area, taking into consideration not only local changes in microcirculation, but also the effect of vasotomy on the general microvasculature.

\section{References:}

1. Егоров, В. И., Козаренко, А. В. \& Казакова, Э. Ж. (2006) Эффрективность хирургического лечения вазомоторного ринита (различные методы, сроки: выполнения). Материалы XVII'съезда оторинолар: России. Нижний Новгород, (с. 273-274), 7-9 июня 2006. СанктПетербург.

2. Evan, M. Feldman (2010). Contemporary techniques in inferior turbinate reduction: survey results of the American society for aesthetic plastic surgery. Aestetic Surgery Journal, 672-679.

3. Nur Wahidah, B. Wahid \& Carl Shermetaro (2019). Rhinitis Medicamentosa. - Treasure Island (FL): StatPearls Publishing. Retrieved from https:/www.ncbi.nlm.nih.gov/books/NBK538318/.

DOI 10.36074/25.10.2019.v2.07

\section{THE LEVELS OF ANXIETY IN INTERNALLY DISPLACED PERSONS IN MODERN CONDITIONS}

\section{RESEARCH GROUP:}

Hanna Kozhyna

D.Sc. (Medicine), Professor, Head of the Department of Psychiatry, Narcology, Medical Psychology and Social Work Kharkiv National Medical University

Kateryna Zelenska Ph.D. (Medicine), Associate Professor of the Department of Psychiatry, Narcology, Medical Psychology and Social Work Kharkiv National Medical University

Tetiana Kraskovska

Ph.D. student of the Department of Psychiatry, Narcology, Medical Psychology and Social Work Kharkiv National Medical University

UKRAINE

Topicality. Mental health disorders in IDPs (internally displaced persons) are various and affect almost all areas of the psyche [1]. The lack of positive motivation to move and the physical impossibility of further stay at homeland, traumatization of the psyche due to causes of migration, as well as the difficulties of adaptation to a new place determine the formation of specific experience of internally displaced 
persons [2]. The most common of these are anxiety disorders. Therefore, the relevance of the selected study is aimed at identifying key symptoms with the further development of new models of psychotherapy interventions in this population.

Objective: To study the features of anxiety symptoms in IDPs and residents of Kharkiv region.

Materials and methods: the study was conducted on the basis of KNP CHOR "Regional Clinical Psychiatric Hospital №3". A comprehensive examination was conducted of 44 patients with anxiety disorders, both sexes, aged 20 - 55 years. The main group consisted of 19 sick IDPs, control - 25 patients who permanently reside in Kharkiv region. We have used the following psychodiagnostic techniques: the Hospital Anxiety and Depression Scale (HADS) (Zigmond A.S., Snaith R.P., 1983); Spielberger - Yu.L. Hanina (State - TraitAnxietylnvertory - STAI, 1985).

Results: The following data was obtained for the HADS: subclinical anxiety was reported in $5(26.31 \%)$ displaced persons and $9(37.5 \%)$ locals, subclinical depression in $7(36.84 \%)$ and $13(54.17 \%)$ respectively; clinical manifestations of anxiety were $14(73.69 \%)$ and $15(62.5 \%)$, respectively, clinical manifestations of depression were $12(63.16 \%)$ and $11(45.83 \%)$, respectively. On the Self-Esteem Scale: low anxiety was observed in $3(15.78 \%)$ displaced persons and $5(20.83 \%)$ in locals; moderate anxiety in $5(26.31 \%)$ and $12(50 \%)$, respectively; expressed anxiety - $11(57.91 \%)$ and $8(29.17 \%)$ respectively.

Conclusions. The obtained results indicate that the severity of anxiety and depressive symptoms is higher in IDP patients, therefore more attention should be paid to psychotherapeutic interventions. The obtained data allow us to develop in future and implement a comprehensive system for the treatment of IDPs with anxiety disorders.

\section{References:}

1. Martsenkovskyi, D. I. (2018). Vikovyi polimorfizm posttravmatychnykh stresovykh rozladiv ta depresii u ditei vnutrishno peremishchenykh osib z okupovanykh terytorii [Age-related polymorphism of post-traumatic stress disorders and depression in children of internally displaced persons from the occupied territories]. Arkhiv psykhiatrii, $(24,1 / 92), 15-20$.

2. Shpylovyi. Ya. V. (2017). Klinichnyi zmist i vyrazhenist depresyvnykh i tryvozhnykh fenomeniv v strukturi nevrotychnykh tryvozhno-depresyvnykh rozladiv riznoho psykhogenezu u zhinok (vymushenykh pereselentsiv ta druzhyn viiskovosluzhbovtsiv - uchasnykiv ATO) [Clinical content and severity of depressive and anxiety phenomena in the structure of neurotic anxiety-depressive disorders of different psychogenesis in women (IDPs and wives of ATO participants)]. Ukrainskyi visnyk psykhonevrolohii, (25, 2/91), 88-91. 


\title{
TRADITIONAL AND MINIMALLY INVASIVE OPERATIVE METHODS OF TREATMENT OF PERFORATED GASTRODUODENAL ULCERS
}

\author{
Yelyzaveta Lisova \\ student of the Medical faculty \\ Kharkiv National Medical University
}

Scientific adviser: Vadym Lesnoy Viktorovych

Ph. D., Assistant of the Department of Surgery № 2

Kharkiv National Medical University

UKRAINE

Introduction. Peptic ulcer of the stomach and duodenum is one of the most important health problems. Among all the complications of gastric and duodenal ulcers, ulcer perforation remains one of the most severe and requires immediate surgical treatment. This complication occurs on average in $15 \%$ of all patients with peptic ulcer [1].

In spite of the emergence of modern antiulcer drugs and the success of conservative treatment of peptic ulcer, the incidence of ulcer perforation has no tendency to decrease. Until now, mortality in perforated ulcers remains high, ranging from 4 to $14 \%$. A perforated gastric or duodenal ulcer is an absolute surgical indication. The most common operation is suturing the perforation with double-row sutures. The active introduction of mini-accesses and video-laparoscopic techniques in urgent surgery has expanded both the diagnostic and therapeutic capabilities of surgeons $[2,3]$.

The purpose of this work was to study the results of modern treatment of perforated pyloroduodenal ulcers.

Research materials and methods. The case histories of 52 patients (random sampling) who were hospitalized in the surgical department from 2018 to 2019 were analyzed. There were $12(23 \%)$ women and $40(77 \%)$ men. The age of patients ranged from 24 to 78 years. The average age of patients is 43 years.

At the time of hospitalization, patients complained of: intense pain on the right flank - $46(88,5 \%)$ patients, spreading pain to the right supraclavicular region - 24 $(46,2 \%)$; heartburning, nausea - $20(38,5 \%)$.

Terms from the onset of symptoms of perforation to hospitalization were: up to 6 hours $-30(57,7 \%), 6-12$ hours $-20(38,5 \%), 12-24 \%$ hours $-2(3,8 \%)$ patients. From the anamnesis of life it is revealed that only $6(11,5 \%)$ patients were registered at the gastroenterologist because of a peptic ulcer; at $18(34,6 \%)$ patients perforation of an ulcer was the first manifestation of a peptic ulcer.

At the physical examination it is verified: board-like muscle tension in the epigastrium along the right flank - $46(88,5 \%)$ patients, a positive Spizharny's sign (disappearance of hepatic dullness) $-40(77 \%)$, a positive Blumberg's sign -50 $(96,2 \%)$.

At X-ray study of the abdominal organs in vertical position, free gas under the right diaphragm dome was found at $39(75 \%)$ patients that demanded carrying out a pneumogastrography to $13(25 \%)$ patients. 
Research results. The operation of choice at $30(57,7 \%)$ patients with perforation of a chronic gastroduodenal ulcer was laparotomy, excision of the ulcerated substrate by Judd-Horsley method, pyloroduodenoplasty, debridement, drainage of the abdominal cavity.

In $8(15,4 \%)$ patients with diagnostic laparoscopy, perforation sizes up to $1 \mathrm{~cm}$ were established. Laparoscopic suturing of perforated ulcers, debridement and abdominal drainage were performed.

Simple ulcer suturing, debridement and abdominal drainage were performed in $6(11,5 \%)$ patients with perforated gasrtoduodenal ulcer, due to unstable hemodynamics and concomitant pathology in the decompensation stage.

Stomach resection by Balfour's method $(3,8 \%)$, ulcer excision with suturing $(9,6 \%)$, tamponade by Oppel $(1,9 \%)$ were realized in eight patients with perforative gastroduodenal ulcers.

A perforated duodenal ulcer was diagnosed in $44(84,6 \%)$ patients, and a stomach ulcer in $8(15,4 \%)$. The postoperative period after the open surgical interventions was complicated in $5(9,6 \%)$ patients. Complications such as suppuration of a postoperative wound $-2(3,9 \%)$ cases, $1(1,9 \%)$ case of a suture failure of the ulcer, $2(3,9 \%)$ intraabdominal abscesses were noted. Complications were eliminated by minimally invasive methods: intraabdominal abscesses were punctured under ultrasound control; in case of failure of sutures of pyloric part of stomach was performed a stenting of this part. The average duration of hospitalization was $6 \pm 1,2$ days $(p>0,05)$ in patients with laparoscopic method, and $9 \pm 1,5$ days with traditional treatment. The case of fatality in the study group is 1 $(1,9 \%)$ due to severe endogenous intoxication which caused multiple organ failure; ulcer malignancy was histologically confirmed.

Conclusions. This study showed that the use of videoendoscopic methods of surgical treatment can reduce the intensity of the pain syndrome and duration of hospitalization. Minimally invasive suturing methods can be used depending on the size of the perforated hole. This tactic allows avoiding sutures failure in the postoperative period and conversion to laparotomy during operations. Laparoscopic suturing of an ulcer is the operation of choice in case of a perforated ulcer of the pyloroduodenal canal size up to $1 \mathrm{~cm}$ in the absence of other associated ulcer complications, duration of peritonitis up to 6 hours, with no contraindications to pneumoperitoneum application.

\section{References:}

1. Chang, Y. C. (1999). Abdominal wall-lifting laparoscopic simple closure for perforated peptic ulcer. Hepato-gastroenterology (46), (28), 2246-2248. [PubMed: 10521974].

2. Lau, H. (2004). Laparoscopic repair of perforated peptic ulcer: a meta-analysis. Surgical Endoscopy, 18(7), 1013-1021. https://doi.org/10.1007/s00464-003-8266-y.

3. Шишов, Д. Ю. (2012). Ближайшие результаты традиционного и лапароскопического ушивания перфоративных язв желудка и двенадцатиперстной кишки. Журнал МедиАль, 1(4). 


\title{
АСПЕКТИ ПОЄДНАНОÏ ХІМІОТЕРАПІЇ І ОНКОВІРОТЕРАПІЇ У

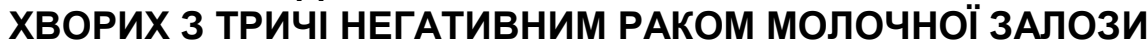

\author{
Александрова Катерина Володимирівна \\ Харківський національний медичний університет
}

Журавльова Поліна Володимирівна

Харківський національний медичний університет

Науковий керівник: Гаврилов Андрій Юрійович

асистент кафедри онкології

Харківський національний медичний університет

УКРӒ̈HA

Актуальність. Наразі рак молочної залози (РМЗ) $€$ одним 3 найпоширеніших видів онкології згідно ВООЗ. Тяжкість перебігу даної патології ускладнюється пізньою діагностикою, що унеможливлює проведення радикальних методів терапії. Тричі негативний рак молочної залози (ТНРМЗ) виявляється в $20 \pm 1,3 \%$ випадків і являє собою особливу форму даної онкології, оскільки характеризується відсутністю естрогенових, прогестеронових рецепторів і білка HER2, що робить неможливим проведення гормональної терапії і примушує до пошуку більш раціонального методу лікування [1].

Метою є дослідження перспективи імунотерапії ТНРМЗ онколітичними вірусами в комбінації з неоад'ювантною хіміотерапією для досягнення більш високої 3-річної та 5-річної виживаності.

Матеріали та методи. Були проведені систематичний огляд літератури (дані Hinari, Pubmed, Medscape з 2014 по 2019 р.), обробка та ретроспективний метааналіз емпіричних даних щодо дослідження онковіротерапії ТНРМЗ in vitro на клітинних лініях і культурах клітин, експериментах in vivo і мишачих моделях пухлин; а також результатів гістологічного і цитологічного аналізів до і після проведеної терапії [1, 2]. Також було проведено власне дослідження, засноване на спостереженні 118 клінічних випадків пацієнтів з діагнозом РМЗ з 2013 по 2018 р. Основним параметром дослідження була відповідь ракових клітин на проведену онковіротерапію з хіміотерапією порівняно $з$ класичною полі хіміотерапією [3].

«Класичними» схемами поліхіміотерапії РМ3 є патерни з 2-х або 3-х компонентів. У більшості випадків $(92 \pm 1,7 \%)$ використовувалися схеми: CMF (циклофоссрамід, метотрексат, 5-фрторурацил), FEC (5-фрторурацил, епірубіцин, ціклофосфрамід), доцетаксел у поєднанні з паклітакселом [1,2].

Результати. Аналіз клінічних досліджень показав, що виживаність у пацієнтів з ТНРМЗ з класичною схемою поліхіміотерапії нижче виживання у пацієнтів з іншими видами РМЗ з аналогічним видом терапії на $17 \pm 0,2 \%$ в перші 3 роки і на 24 0,4\% в наступні 5 років після лікування [3]. Дані результати показують високу летальність серед хворих тричі негативним раком молочної залози і безперечно вимагають пошуку більш проспективного методу терапії, на даному етапі - вивчення властивостей онколітичних вірусів. Була доведена ефективність віротерапії за допомогою реовірусе 3 серотипу, 
мутантного вірусу герпесу першого типу, а також більш перспективного варіанта - віруса Мараба (MG1), рекомбінантна модифрікація якого використовувалася в $72 \%$ досліджень [1, 2]. Для онковіротерапії в дослідженні in vivo використовувалося внутрішньопухлинне i системне введення; результати показали: більш висока ефективність спостерігалася в першому випадку, загибель пухлинних клітин за результатами гістологічного і цитологічного дослідження перевершувала системне введення на $11,3 \%$.

Також, результат дослідження пухлинного субстрату на мишах показав високу дієвість комбінації віротерапії з монохіміотерапією, ніж класичний варіант поліхіміотерапії для ТНРМ3 [1].

Висновки. Так як РМЗ в більшій мірі виявляється на вже серйозних стадіях пухлинного процесу, онковіротерапія може вважатися досить ефективною, оскільки при пізніх стадіях онкологічного процесу на рівні макроорганізму буде пригнічена імунна відповідь, що для вірусу буде платформою для продуктивної реплікації. Діскутабельним питанням залишається ризик побічних ефектів у вигляді розвитку самого захворювання властивого заданоvе вірусу, що потребує більш детального вивчення питання з боку генної інженерії; вивчення з боку можливого запровадження подвійної онковіротерапії, де разом 3 онколітичним вірусом буде вводитися конкурентоспроможний апатогенний вірус. Всесвітнє співтовариство все ще не прийшло до єдиної консенсусу в питаннях віротерапії онкологічних захворювань і дана тема має потребу у поглибленому вивченні механізмів дії і проведенні додаткових клінічних випробувань.

\section{Список використаних джерел:}

1. Marie-Claude Bourgeois-Daigneault \& Lauren Elizabeth St-Germain [et al.] (2016). Combination of Paclitaxel and MG1 Oncolytic Virus as a Successful Strategy for Breast Cancer Treatment. Breast Cancer Res. 18(83).

2. Rodríguez Stewart, R. M. \& Berry, J. T. L. [et al.] (2019). Enhanced Killing of Triple-Negative Breast Cancer Cells by Reassortant Reovirus and Topoisomerase Inhibitors. Journal of virology. 11(19). https://doi.org/10.1128/JVI.01411-19.

3. Сивак, Л. А., Лялькин, С. А., Майданевич, Н. Н., Климанов, М. Ю., Аскольский, А. В. \& Касап, Н. В. (2013). Трижды негативный рак грудной железы: современный взгляд на проблему. Клиническая онкология № 3 (11). 


\title{
ВПЛИВ СЕЛЕКТИВНОЇ ДЕКОНТАМІНАЦІЇ ШЛУНКОВО- КИШКОВОГО ТРАКТУ НА ВИЖИВАНІСТЬ У ПАЦІЄНТІВ, ЯКІ ПЕРЕБУВАЮТЬ У ВІДДІЛЕННЯХ РЕАНІМАЦІЇ ТА IHТЕНСИВНОÏ ТЕРАПIÏ
}

\author{
Александрова Катерина Володимирівна \\ Харківський національний медичний університет \\ Журавльова Поліна Володимирівна \\ Харківський національний медичний університет
}

Науковий керівник: Саркіс-Іванова В.В. асистент кафедри кафедри гігієни та екології №1 Харківський національний медичний університет

УКРАЇ̈А

Актуальність. Одна з найважливіших функцій нормальної мікрофлори кишківника - участь в колонізаційної резистентності, під якою розуміють захисні здатності анаеробів кишківника перебувати в конкурентних та антагоністичних відносинах зі сторонніми мікроорганізмами та запобігати їх розмноженню та розповсюдженню. У деяких відділеннях інтенсивної терапії та реанімації проводять досить нову процедуру - selective decontamination of the digestive tract (SDD) [1]. Процедура спрямована на визначення резистентних бактерій в шлунково-кишковому тракті і їх знищення. Єдиного наукового консенсусу з даного питання до сих пір не існує, бо за даними одних дослідників ця процедура знижує смертність у відділеннях інтенсивної терапії та зменшує використання антибіотиків з групи резерву, за даними інших - це лише нераціональне використання антибіотиків, ресурсів та коштів. Наразі вивчення питання впливу SDD на функції організму, перебіг патологій та реконвалесценцію пацієнтів $є$ надзвичайно актуальним $[1,2]$.

Mema. Дослідження ефективності впливу селективної деконтамінації шлунково-кишкового тракту на виживаність у пацієнтів, які знаходяться на ШВЛ у відділеннях реанімації та інтенсивної терапії.

Memoдu. Збір емпіричних даних та огляд літератури, щодо проведеного проспективного, контрольованого, радомізованого клінічного дослідження, в якому 445 пацієнтів отримували або профілактичні неабсорбуючі антибіотики ( $n=220)$, або плацебо $(n=225)$. Місцеві антибіотики (тобраміцин, колістин сульфат і амфотерицин В) або плацебо вводили через назогастральную трубку і наносили на ротоглотку протягом всього періоду штучної вентиляції [1, 2]. Основними параметрами були рівень смертності у відділенні інтенсивної терапії та рівень смертності протягом 60 днів після рандомізації.

Результати. Всього в реанімаційному відділенні за даними дослідження померло 142 пацієнтів, які перебували на ШВЛ: 75 (34 \%) у групі лікування та 67 (30 \%) у групі плацебо [2]. Смертність протягом 60 днів після рандомізації була однаковою у двох групах. Пневмонія розвинулася у 59 пацієнтів (13\%) у відділенні інтенсивної терапії протягом 30 днів після участі в дослідженні (33 у групі плацебо та 26 у групі лікування). Пневмонія, набута у відділенні інтенсивної терапії через грамнегативні бактерії, була менш частою у групі лікування, ніж у групі плацебо. Загальна сума витрат на антибіотики була в 2,2 рази вищою для групи лікування $[1,2]$. 


\section{Висновки.}

1. Селективна деконтаминація не покращує виживаності пацієнтів, які знаходяться на ШВЛ, хоча значно збільшує витрати на отримання пацієнтів в відділеннях інтенсивної терапії.

2. Селективна деконтаминація безсумнівно знижує відсоток зараження на госпітальну пневмонію.

3. Метод селективної деконтамінації потребує впровадження оптимізованих схем з використанням пробіотиків, с метою зменшення витрат, підвищення виживаності пацієнтів та удосконалення результатів подальших досліджень.

4. Результати клінічних досліджень застосування селективної деконтамінації в лікуванні пацієнтів відділень інтенсивної дуже контраверсійні, бо існують різні схеми використання IIB, у зв'язку з чим це питання потребує подальшого вивчення.

\section{Список використаних джерел:}

1. Evert de Jonge, Marcus J Schultz, Lodewijk Spanjaard \& Jozef Kesecioglu (2003). Effects of selective decontamination of digestive tract on mortality and acquisition of resistant bacteria in intensive care: a randomised controlled trial. The Lancet, (362),1011-1016. https://doi.org/10.1016/S0140-6736(03)14409-1.

2. Gastinne, H., Wolff, M., Delatou, F. \& Faurisson, F. (1992). A Controlled Trial in Intensive Care Units of Selective Decontamination of the Digestive Tract with Nonabsorbable Antibiotics. The New England Journal Of Medicine (326), 594-599.

DOI 10.36074/25.10.2019.v2.08

ДОСЛІДЖЕННЯ ВПЛИВУ БАГАТОКОМПОНЕНТНИХ ОРГАНІЧНИХ СУМІШЕЙ НА ОСНОВІ ГЛІКОЛІВ НА СТАН МЕТАБОЛІЧНИХ ПРОЦЕСІВ У ПРАЦІВНИКІВ ВО «КАПРОЛАКТАМ» ІНТЕГРАТИВНИМ МЕТОДОМ БІОХЕМІЛЮМІНЕСЦЕНЦІї

Сіренко Олена Віталіївна

канд. мед. наук, доцент, доцент кафедри клінічної лабораторної діагностики Харківська медична академія післядипломної освіти

Кучеренко Ела Олексіївна канд. мед. наук, доцент, доцент кафедри клінічної лабораторної діагностики Харківська медична академія післядипломної освіти УКРАÏHA

Однією з важливих задач превентивної медицини є використання методів лабораторної діагностики, які дають змогу оцінити стан здоров'я людини та своєчасно коригувати виниклі метаболічні порушення. Відомо, що пусковим моментом багатьох патологічних станів, які відносять до «екологічної патології», є порушення метаболічних процесів та гомеостазу, що негативно 
впливає на відновлення та синтез структурно-функціональних одиниць організму [1]. Доцільність використання такого високоінформативного та неінвазивного методу як біохемілюмінесценція (БХЛ) для діагностики функціонального стану організму людини відома [2]. Даний цитобіофрізичний метод дослідження заснований на реєстрації змін інтенсивності світіння клітини та її ультраструктур у відповідь на зсуви у стані біохімічного гомеостазу при впливі несприятливих чинників навколишнього середовища [2]. Метод БХЛ $€$ інтегративним тестом для визначення структурно-функціонального стану клітини, внутрішньоклітинних метаболічних процесів при впливі хімічних патогенів [3].

3 метою виявлення донозологічних метаболічних зсувів у стані здоров'я працівників підприємства ВО «Капролактам» (м. Дзержинськ, Росія), які контактують з багатокомпонентними органічними сумішами на основі гліколів та проміжними продуктами їх синтезу, використовували метод БХЛ.

Методи та матеріали. Були обстежені 122 працівника виробничих цехів та 57 співробітників інженерно-технічної групи (ITP) у якості контрольної групи. Дослідження проводили, коли термін існування виробництва та трудовий стаж працівників дорівнював 4 роки. Групу обстежених склали чоловіки віком від 20 до 60 років. Вплив БКОС на основі гліколів на метаболічні процеси, у тому числі, вільнорадикальні, оцінювали шляхом вимірювання інтенсивності індукованої $0,5 \% \mathrm{H}_{2} \mathrm{O}_{2}$ БХЛ сечі працівників, для чого зразки біоматеріалу розміщували у темновій камері і термостатували у біостаті при $37^{\circ} \mathrm{C}$, після чого реєстрували власний та індукований спалахи світіння протягом 1,5-3 хвилин на вітчизняному медичному біохемілюмінометрі БХЛМЦ 1-01 [5]. При проведенні первинного розвідувального статистичного аналізу для перевірки нормальності розподілу кількісних показників, що вивчалися, з використанням критерію Колмогорова-Смірнова була встановлена необхідність застосування непараметричних методів статистичного дослідження. На підставі цього факту перевірка гіпотези про парну міжгрупову різницю проводилася за допомогою U-критерію Манна-Уітні (U, z). Критичне значення рівня значущості (p) приймалося рівним 0,05. Для кількісних показників параметри описової статистики наводилися у вигляді медіани та квартилей (Me $(25 ; 75)$.

Результати та обговорення. Реєстрація інтенсивності БХЛ сечі працівників, які безпосередньо контактували 3 багатокомпонентними органічними сумішами, виявила суттєве перевищення показників індукованого світіння у порівнянні з групою ITP, а найбільша інтенсивність хемілюмінесценції визначена у віковій групі від 31 до 40 років (табл. 1).

Таблиця 1

Показники індукованої БХЛ сечі працівників ВО «Капролактам» $(\mathrm{Me}(25 ; 75)$

\begin{tabular}{|c|c|c|c|c|c|}
\hline \multirow{3}{*}{ Професія } & \multirow{3}{*}{$\mathrm{N}$} & \multicolumn{4}{|c|}{ Вік (років) } \\
\hline & & $20-30$ & $31-40$ & $41-50$ & $51-60$ \\
\hline & & \multicolumn{4}{|c|}{ Біохемілюмінесценція, $\left(\mathrm{J}^{\circ}\right)$ імп/с. } \\
\hline Контроль & 57 & $\begin{array}{c}906 \\
(897 ; 916)\end{array}$ & $\begin{array}{c}954 \\
(753 ; 1110)\end{array}$ & $\begin{array}{c}854 \\
(569 ; 1002)\end{array}$ & $\begin{array}{c}587 \\
(456 ; 854)\end{array}$ \\
\hline
\end{tabular}


October 25, $2019 \bullet$ Edinburgh, Scotland, UK • 35

Продовження табл. 1

\begin{tabular}{|c|c|c|c|c|c|}
\hline \multirow{3}{*}{ Професія } & \multirow{3}{*}{$\mathrm{N}$} & \multicolumn{4}{|c|}{ Вік (років) } \\
\hline & & $20-30$ & $31-40$ & $41-50$ & $51-60$ \\
\hline & & \multicolumn{4}{|c|}{ Біохемілюмінесценція, $\left(\mathrm{J}^{\circ}\right)$ імп/с. } \\
\hline $\begin{array}{c}\text { Апаратники: } \\
\text { перегонки }\end{array}$ & 21 & $\begin{array}{c}1206 \\
(985 ; 1456) \\
U=258,5 \\
z=-3,83 \\
p<0,001\end{array}$ & $\begin{array}{c}1292 \\
(987 ; 1452) \\
U=297 \\
z=-3,40 \\
p=0,001\end{array}$ & $\begin{array}{c}998 \\
(874 ; 1120) \\
U=399,5 \\
z=-2,24 \\
p=0,025\end{array}$ & $\begin{array}{c}375 \\
(258 ; 456) \\
U=239 \\
Z=-4,05 \\
p<0,001\end{array}$ \\
\hline синтезу & 18 & $\begin{array}{c}1293 \\
(1096 ; 1369) \\
U=6 \\
z=-6,29 \\
p<0,001\end{array}$ & $\begin{array}{c}1400 \\
(1236 ; 1525) \\
U=143,5 \\
z=-4,59 \\
p<0,001\end{array}$ & $\begin{array}{c}1130 \\
(1023 ; 1236) \\
U=270,5 \\
z=-3,01 \\
p=0,003\end{array}$ & $\begin{array}{c}257 \\
(208 ; 300) \\
U=95 \\
z=-5,19 \\
p<0,001\end{array}$ \\
\hline окиснення & 10 & $\begin{array}{c}1156 \\
(1078 ; 1236) \\
U=3,5 \\
z=-4,95 \\
p<0,001\end{array}$ & $\begin{array}{c}1226 \\
(1187 ; 1265) \\
U=132 \\
z=-2,69 \\
p=0,007\end{array}$ & $\begin{array}{c}1127 \\
(1025 ; 1187) \\
U=136 \\
z=-2,62 \\
p=0,009\end{array}$ & $\begin{array}{c}333 \\
(320 ; 357) \\
U=60 \\
z=-3,96 \\
p<0,001\end{array}$ \\
\hline гідратації & 24 & $\begin{array}{c}1236 \\
(1124 ; 1365) \\
U=0,000 \\
z=-7,08 \\
p<0,001\end{array}$ & $\begin{array}{c}1250 \\
(1196 ; 1365) \\
U=258 \\
z=-4,40 \\
p<0,001\end{array}$ & $\begin{array}{c}1232 \\
(1114 ; 1310) \\
U=281 \\
z=-4,17 \\
p<0,001\end{array}$ & $\begin{array}{c}293 \\
(222 ; 455) \\
U=193 \\
z=-5,08 \\
p<0,001\end{array}$ \\
\hline навантаження & 9 & $\begin{array}{c}1106 \\
(1089 ; 1178) \\
U=38,5 \\
z=4,3 \\
p<0,001\end{array}$ & $\begin{array}{c}1274 \\
(1225 ; 1345) \\
U=105,5 \\
z=-2,82 \\
p=0,005\end{array}$ & $\begin{array}{c}1050 \\
(1000 ; 1109) \\
U=138,5 \\
z=-2,21 \\
p=0,027\end{array}$ & $\begin{array}{c}320 \\
(298 ; 350) \\
U=48,5 \\
z=-3,89 \\
p p<0,001\end{array}$ \\
\hline Майстри зміни & 11 & $\begin{array}{c}951 \\
(899 ; 970) \\
U=201 \\
z=-1,87 \\
p=0,061\end{array}$ & $\begin{array}{c}1036 \\
(994 ; 1113) \\
U=209 \\
z=-1,74 \\
p=0,082\end{array}$ & $\begin{array}{c}841 \\
(767 ; 857) \\
U=305 \\
z=-0,142 \\
p=0,887\end{array}$ & $\begin{array}{c}583 \\
(567 ; 619) \\
U=291 \\
z=-0,367 \\
p=0,714\end{array}$ \\
\hline Електрики & 7 & $\begin{array}{c}869(820 ; 913) \\
U=131 \\
z=-1,47 \\
p=0,146\end{array}$ & $\begin{array}{c}975 \\
(910 ; 1042) \\
U=173,5 \\
Z=-0,576 \\
p=0,584\end{array}$ & $\begin{array}{c}815 \\
(782 ; 835) \\
U=183 \\
z=-0,355 \\
p=0,736\end{array}$ & $\begin{array}{c}519 \\
(491 ; 523) \\
U=146 \\
z=-1,15 \\
p=0,263\end{array}$ \\
\hline Слюсарі КІП & 12 & $\begin{array}{c}858 \\
(771 ; 957) \\
U=286 \\
z=-0,887 \\
p=0,375\end{array}$ & $\begin{array}{c}958 \\
(898 ; 1023) \\
U=314 \\
z=-0,444 \\
p=0,657\end{array}$ & $\begin{array}{c}723 \\
(654 ; 743) \\
U=254 \\
z=-1,39 \\
p=0,166\end{array}$ & $\begin{array}{c}406 \\
(363 ; 434) \\
U=136,5 \\
z=-3,26 \\
p=0,001\end{array}$ \\
\hline $\begin{array}{c}\text { Слюсарі з } \\
\text { ремонту } \\
\text { обладнання }\end{array}$ & 10 & $\begin{array}{c}969 \\
(895 ; 991) \\
U=168 \\
z=-2,059 \\
p=0,039\end{array}$ & $\begin{array}{c}1103 \\
(1051 ; 1134) \\
U=156 \\
z=-2,27 \\
p=0,023\end{array}$ & $\begin{array}{c}661 \\
(604 ; 742) \\
U=184,5 \\
z=-1,77 \\
p=0,077\end{array}$ & $\begin{array}{c}411 \\
(365 ; 423) \\
U=106 \\
z=-3,15 \\
p<0,002\end{array}$ \\
\hline
\end{tabular}

[авторська розробка]

Обробка отриманих даних БХЛ сечі працівників ВО «Капролактам» різних вікових груп виявила статистично значуще збільшення інтенсивності світіння зразків біоматеріалу у апаратників перегонки віком 20-30 та 31-40 років, у середньому на $34,3 \%$ ( $<<0,001)$, а у віковій групі $41-50$ років тільки на $16,9 \%$ $(p<0,025)$ у порівнянні з аналогічними результатами контрольної групи. У той 
же час, визначено зниження показників БХЛ сечі у працівників віком 51-60 років на 36,1\% ( $<<0,001)$. Показники БХЛ сечі апаратників синтезу перевищували ITP у віковій групі 20-30 років та $31-40$ років у середньому на $44,8 \%$ ( $<<0,001)$, а у віковій групі 41-50 років, як у апаратників синтезу, так і окиснення, - у середньому на $32,0 \%$ ( $<<0,01)$. Зміни інтенсивності світіння сечі працівників були визначені на тлі зниження інтенсивності БХЛ у апаратників синтезу та окиснення у віковій групі 51-60 років на 56,2\% (p<0,001) та на 43,3\% (p<0,001) відповідно, у порівнянні 3 даними ITP. У апаратників гідратації та навантаження вікової групи 20-30 років визначали збільшення інтенсивності БХЛ на $36,4 \%(p<0,001)$ та на 22,1\% (p<0,001) відповідно, як і у віковій групі 41 50 років, коли значення показників збільшувалися на $44,3 \%(p<0,001)$ і на $23,0 \%$ ( $<<0,001)$ відповідно, на тлі зниження інтенсивності світіння зразків біоматеріалу у віковій групі $51-60$ років на $20,1 \%(p<0,001)$ та на 45,5\% $(p<0,001)$ відповідно.

Визначене зменшення інтенсивності БХЛ у віковій групі від 50 до 60 років може свідчити про особливості змін метаболізму, пов'язані саме з віком, та виснаження механізмів адаптації у працівників, які безпосередньо контактували з органічними сумішами [4].

\section{Висновки:}

1. Вплив багатокомпонентних органічних сумішей та проміжних продуктів їх синтезу призводив до інтенсифікації індукованої БХЛ сечі працівників ВО «Капролактам» різних вікових груп, що проявлялося перевищенням контрольних показників у апаратників перегонки віком 20-30 та 31-40 років у середньому на $34,3 \%$ ( $p<0,001)$, у апаратників синтезу - у середньому на $44,8 \%$ ( $p<0,001)$, у апаратників гідратації та навантаження вікової групи 20-30 років - на 36,4\% $(p<0,001)$ та на 22,1\% $(p<0,001)$ на тлі зниження інтенсивності БХЛ сечі у працівників віком 51-60 років, що може свідчити про надмірну активацію вільнорадикальних процесів в організмі при впливі хімічних речовин.

2. Дослідження біоматеріалу хемілюмінесцентним методом $\epsilon$ інформативним, неінвазивним, економічним, який доцільно використовувати при обстеженні великих контингентів населення, що контактує зі шкідливими хімічними речовинами, для своєчасного виявлення метаболічних порушень.

\section{Список використаних джерел:}

1. Cederbaum, A. I. (2015). Molecular mechanisms of the microsomal mixed function oxidases and biological and pathological implications. Redox. Biology. (4). 60-73. Вилучено 3 http://www.ncbi.nlm.nih.gov/pubmed/25498968.

2. Жуков, В. И., Зайцева, О. В. \& Антюфеева, О. И. (2005) Связь параметров динамики биохемилюминесценции со степенью кумуляции ксенобиотиков. Экспериментальная и клиническая медицина, (2), 51-55.

3. Щербань, М. Г., М'ясоєдов, В. В. \& Шевченко, О. О. (2010) Методичні аспекти використання методології оцінки ризику здоров'ю населення при впливі факторів навколишнього середовища в Україні та Росії. Вісник ХНУ ім. В.Н.Каразіна, $(898,19), 97-104$.

4. Данилова, Л. А. (2014). Анализы крови, мочи и других биологических жидкостей человека в различные возрастные периоды. Санкт-Петербург: СПЕЦЛИТ.

5. Сіренко, О. В., Жуков, В. І., Кучеренко, Е. О. (2009). Спосіб доклінічної оцінки інтоксикації організму від впливу ксенобіотиків (Пат. UA №46608 України, МПК G01N 33/48; № u 2009 07866). Заявл. 27.07.2009; Опубл. 25.12.2009, Бюл. № 24. 


\section{ГАДЖЕТИ: КОРИСТЬ ЧИ ШКОДА?}

НАУкОВО-ДОслІДНА ГРУПА:
Коробчанський Володимир Олексійович
директор НДІ гігієни праці та професійних захворювань, профресор кафедри
гігієни та екології № 1 ХНМУ
Харківський національний медичний університет
Нестеренко Валентина Геннадіївна
канд. мед. наук, асистент кафедри гігієни та екології № 1
Харківський національний медичний університет
Каднай Олексій Сергійович
здобувач вищої освіти І медичного факультету
Харківський національний медичний університет
УКРАїнА

Сучасне життя вимагає швидкого прийняття рішень та опрацювання великої кількості інформації одночасно. В цьому допомагають електронні прилади такі як: телефон, смартфон, електронна книга, планшет, комп'ютер, тощо.

Діти віддають перевагу використанню гаджетів в порівнянні зі звичайними книжками. Значно легше та швидше знайти будь-яку інформацію в інтернеті, ніж в паперовій книжці. Але чи так це безпечно, як здається на перший погляд?

Електронні носії інформації значно спрощують життя сучасних дітей в питаннях пошуку інформації для навчання та розваг. Діти вже не потребують використання паперових носіїв інформації таких як книга або періодичне видання. Але ця легкість та доступність великої кількості інформації не така позитивна, як здається. Гаджети мають негативний вплив на розвиток нервової системи, опорно-рухового апарату та на формування зорового апарату дітей. Діти віддають перевагу гаджетам, а не активному способу життя. Інформація, що знаходиться в мережі не завжди (а в деяких випадках зовсім) відповідає віку дітей. Сьогодні близько 45\% школярів не мають достатньої інформації щодо безпечного використання мережі інтернет [1]. Школярі середньої школи не мають часу для достатньої фізичної активності протягом дня. В результаті цього маємо порушення осанки у школярів, проблеми з зоровим апаратом та проблеми адаптації.

У сучасних школах, де навчання проводиться з використанням комп'ютерів, наявні такі захворювання школярів, як хвороби ендокринної системи $(26,4 \%)$, хвороби органу зору (18,2\%), хвороби опорно-рухового апарату $(13,2 \%)$. Встановлено залежність стану здоров'я підлітків від їх способу життя: тривалості сну, кратності харчування впродовж дня, заняття спортом та усвідомлення підлітками важливості профілактичних заходів [2]. За час навчання у школі вдвічі зростає частка дітей зі скаргами на головний біль під час уроків, на біль у спині - у 2,7 рази ( $p<0,001)$; зростає частка дітей 3 захворюваннями кістково-м'язової системи в 1,8 рази $(p<0,001)[3,4]$.

Більшість школярів не можуть відмовитися від використання електронних приладів навіть на короткий час. Вони не пов'язують погіршення зору 3 
використанням екранів. Діти не завжди мають повний обсяг інформації зі здоров'язберігаючих технологій, тому не можуть використовувати їх якісно.

В цих умовах батьки мають постійно контролювати умови використання гаджетів, інформацію та час, що дитина проводить з ними.

\section{Список використаних джерел:}

1. Уэйкфилд, Дж. (2015). Сколько времени дети проводят перед экраном. Вилучено $з$ https://www.bbc.com/ukrainian/ukraine_in_russian/2015/03/150329_ru_s_children_screens.

2. Алиманова, М. А. (2010). Суточный бюджет времени учащихся начальных классов с разным уровнем двигательной активности. Гигиена и санитария.

3. Баранович, Н. А. (2009). Качество жизни современных школьников: проблемы и пути решения.

4. Березин, И. И., Кретова, И. Г. \& Русакова, Н. В. (2010). Сравнительная оценка условий обучения в средних образовательных учреждениях разного типа. Гигиена и санитария.

DOI 10.36074/25.10.2019.v2.09

\section{ГЛУТАМАТ НАТРІЮ ЯК ХАРЧОВА ДОБАВКА I Iї ВПЛИВ НА ЗДОРОВ'Я}

НАУКОВО-ДОСЛІДНА ГРУПА:

Волков Ігор Ігорович

здобувач вищої освіти медичного факультету Харківський національний медичний університет

Косілова Ольга Юріївна канд. мед. наук, асистент кафедри гігієни та екології №1 Харківський національний медичний університет

Кателевська Наталія Миколаївна канд. мед. наук, доцент кафедри гігієни та екології №1 Харківський національний медичний університет УКРӒ̈̈А

Активне застосування штучних харчових добавок, які знайшли своє широке застосування у сучасній харчовій промисловості, викликає неоднозначне ставлення наукової спільноти, щодо безпеки по відношенню до здоров'я людини. Окреме питання стосується інтенсивного використання глутамату натрію, який був винайдений у 1907 року в Японії вченим Кікуне Ікедою із спеціально оброблених водоростей Комбу [1]. Ця харчова добавка мала особливий, м'ясний смак, за що і отримала японську назву «Умамі». 3 того часу глутамат натрію став незамінною складовою японської кухні, фраст-фуду, різнотипових м'ясних виробів і снеків. В Європі добавці був присвоєний номер E621, за класифрікацією її віднесли до підсилювачів смаку і аромату. Окрім того, глутамат внесений до таблиць кодексу міжнародних стандартів харчових продуктів, що відомий під назвою Codex Alimentarius. 
Дана харчова добавка здатна активувати специфічні глутаматні рецептори на поверхні язика людини. Це рецептори mGLUR-4, mGLUR-1, T1R1, T1R3 [2]. Вважається, що це еволюційне пристосування для вирізнення продуктів із високим вмістом білку серед інших. Підтвердженням цього $є$ наявність невеликої кількості глутамату у добре приготованому м'ясі.

За походженням глутамінова кислота відноситься до групи замінних амінокислот. Вона може надходити як із навколишнього середовища, так i синтезуватись в організмі самостійно. Ендогенна глутамінова кислота $€$ нейромедіатором, вона здатна активувати численні рецептори нервової системи хребетних, у тому числі NMDA-рецептори що беруть участь в генезі психічних захворювань [3]. Під час декарбоксилювання глутамінової кислоти утворюється ГАМК, який виконує функцію гальмівного нейромедіатору.

Сировиною для глутамату натрію $€$ проміжні продукти харчової галузі. Зокрема, використовуються різні цукри, продукти бродіння. Найбільш новим є способ синтезу добавки за допомогою непатогенних Corynebactrium glutamicum, які потребують цукрової патоки і середовища з високим вмістом азоту.

Глутамат, що отриманий із водоростей за біологічними властивостями абсолютно тотожній добавці із інших джерел. В Codex Alimentarius максимальна доза у фінальному продукті встановлена на рівні 10 г/кг [4]. Експерименти на щурах показали, що летальною є вміст добавки 16 г/кг ваги. Зрозуміло, що метаболізм людини і щурів відрізняється, тому не слід достеменно опиратись на відповідні значення.

Особливості впливу глутамату на організм людини обумовлено дією глутамінової кислоти, що здатна подразнювати шлунково-кишковий тракт. Так, разове вживання глутамату у дозі більше 20 грамів викликає розлад шлунку [5]. Нітроген, що міститься в добавці, здатний викликати надмірне навантаження нирок. Дози вище 0.8 г/кг викликають понаднормове підвищення вмісту аміаку в плазмі.

На території України згідно законодавства діють «Санітарні правила і норми по застосуванню харчових добавок». Згідно них, глутамат натрію-1 заміщений може використовуватись у необхідній кількості за технологічної необхідності [6]. Слід звернути особливу увагу на той фракт, що граничну концентрацію вмісту глутамату натрію у продуктах харчування не встановлено. Виробник лише зобов'язується вказувати склад продукту, в тому числі і добавки. Окремою проблемою $є$ використання добавки як способу маскування неякісної сировини. Також, глутамат натрію може бути фактором розвитку алергічних і псевдоалергічних реакцій (неімунного типу) [7]. Ці явища мають дозозалежний характер. Також існують відомості, що значне перевищення дозування глутамату є причиною психічних захворювань.

Окреме занепокоєння викликає факт широкого використання глутамату дитячій харчовій промисловості, де частка ковбасних продуктів і снеків має бути мінімальною. При недодержанні цього правила, відбувається модифікація раціону. Інакше кажучи, дитина починає надавати перевагу смаку, а не якості. Через адаптацію смакових рецепторів до високого вмісту солоного і «м'ясного» смаку, домашня їжа стає більш «прісною», що в подальшому формує нездорові харчові звички та порушення нормального обміну речовин.

3 метою дослідження наявності E621 в продуктах харчування, був проведений огляд продукції трьох найбільших супермаркетів міста Харків 
(Україна). Було досліджено м'ясні вироби 11 торгових марок та 5 виробників снеків. Взагалі досліджено біля 90 найменувань продукції. У результаті цього, наявність глутамату у складі м'ясних виробів заявлена майже у $85 \%$ ковбас і $94 \%$ снеків. Що не може не викликати питань щодо доцільності та безпечності цієї добавки.

Таким чином, глутамат натрію як добавка нині $\epsilon$ незамінним при виробництві м'ясної продукції. При цьому, безпечність Е621 та вплив цієї речовини вимагає подальшого дослідження.

\section{Список використаних джерел:}

1. Ikeda, K. (2002). New Seasonings. Chemical Senses, 27(9), 847-849.

2. Cosme, F. (2017). Is wine savory? Umami taste in wine. SDRP Journal of Food Science \& Technology, 1(3), 100-105.

3. Iwasaki, K., Kasahara, T. \& Sato, M. (1985). Gustatory effectiveness of amino acids in mice: Behavioral and neurophysiological studies. Physiology \& Behavior, 34(4), 531-542.

4. Report of the nineteenth session of the codex committee on food. (2011). Retrieved from https://www.who.int/foodsafety/codex/34thCAC.pdf.

5. Xu, L. (2004). Effect of glutamate on inflammatory responses of intestine and brain after focal cerebral ischemia. World Journal of Gastroenterology, 11(5), 733.

6. Про затвердження Санітарних правил і норм по застосуванню харчових добавок. (1998). Вилучено 3 https://zakon.rada.gov.ua/laws/show/z0715-96.

7. Макарова, С. Г., Намазова-Баранова, Л. С., Вишньова, Є. А., Ерешко, О. А., \& Гордєєва, І. Г. (2017). Гастроінтестинальна харчова алергія у дітей. Питання сучасної nediampiї, 16 (3), 202-212.

\section{ОСОБЛИВОСТІ РОЗВИТКУ СИНДРОМУ ЕМОЦІЙНОГО ВИГОРАННЯ У ПРАЦІВНИКІВ ІНФЕКЦІЙНИХ ЛІКАРЕНЬ}

НАУКОВО-ДОСЛІДНА ГРУПА:

Кателевська Наталія Миколаївна канд. мед. наук, доцент кафедри гігієни та екології №1

Харківський національний медичний університет

Дяченко Ірина Олексіївна канд. мед. наук., доцент кафедри гігієни та екології №1

Харківський національний медичний університет

Пелих Іван Миколайович

здобувач вищої освіти I медичного фракультету Харківський національний медичний університет

УКPAÏHA

Профресія лікаря пов'язана з постійним емоційним напруженням, що безперервно впливає на психічний стан та $€$ фрактором, який здатен спровокувати розлади фрізичного та психічного здоров'я. Одним з найбільш 
розповсюджених розладів нервового стану є емоційне вигорання. В залежності від важкості, напруженості, інтенсивності роботи медичного працівника розвиток емоційного вигорання може носити різноманітний характер. Основні проблеми даного стану пов'язані 3 недостатніми знаннями відносно виникнення, лікування та профілактики синдрому емоційного вигорання $[1,2]$. Особливо гостро ці питання постають при аналізі фракторів ризику виникнення та розвитку емоційного вигорання у медичного персоналу спеціалізованих лікарень, зокрема, інфекційних.

Ціль роботи: проаналізувати особливості розвитку синдрому емоційного вигорання серед медичного персоналу спеціалізованих медичних закладів, на прикладі інфекційних лікарень

Методи дослідження. Аналіз особливостей розвитку синдрому емоційного вигорання серед медичного персоналу інфекційних лікарень проведено за допомогою тестових методик визначення рівня емоційного вигорання та «здатності до співчуття» [3].

Опитування проводилось на базі Харківської обласної клінічної інфекційної лікарні. Тест пройшли 112 осіб, з них 54 - лікарів та 58 медичних сестер.

За результатами тесту $(34,82 \pm 4,50) \%$ працівників знаходяться у фазі емоційного вигорання. Психо-емоційний стан осіб даної групи характеризується роздратованість, небажанням працювати, проявляється агресія. При цьому явище деперсоналізації виявлено у $(23,21 \pm 3,98) \%$ анкетованих осіб. Психо-емоційний стан медичних працівників також характеризується байдужістю, формальним та недбалив виконанням своїх обов'язків, відсутністю співчуття до хворого, чіпляння на людей «ярликів». В той же час, кількість лікарів, які задоволені своєю професією за результатами тесту становить $(41,07 \pm 4,65) \%$.

Порівняно з лікарями у молодшого медичного персоналу стан байдужості

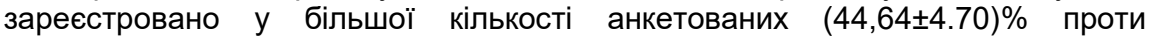
$(23,21 \pm 3,98) \%$. Аналіз характеру роботи свідчить про менш вигідні фрінансові умови праці та специфічний характер роботи із хворими. Особливої уваги потребує той факт, що частіше синдром емоційного вигорання та більш виражена його ступінь виражени у медичних працівників, які за розподілом обов'язків частіше контактують з особами хворими на ВІЛ, туберкульоз та інші тяжкі захворювання.

Таким чином, можно зробити висновок про значний вплив особливостей внутрішньолікарняного середовища, умов праці та особливостей контингенту хворих на формування синдрому емоційного вигорання у медичного персоналу спеціалізованих лікарень. При цьому особливого значення набуває стратегія щодо своєчасного виявлення первинних змін психо-емоційного стану медичних працівників, що можуть передувати формування синдрому емоційного вигорання, та корекція відповідних станів. Особливу увагу слід приділяти молодшому медичному персоналу, як контингенту, що працює у більш несприятливих умовах, щодо ризиків виникнення стресу та психоемоційних розладів.

\section{Список використаних джерел:}

1. Shanafelt, T. D., Hasan, O. \& Dyrbye, L. N., et al. (2015). Changes in burnout and satisfaction with work-life balance in physicians and the general US working population between 2011 and 2014. Mayo Clin Proc, (90), 1600-1613. 
2. Imo, U. O. (2017). Burnout and psychiatric morbidity among doctors in the UK: a systematic literature review of prevalence and associated factors. Psychiatrist, (41), 197-204.

3. Водоп'янова, Н. Є. \& Старченкова, Е. С. (2005). Синдром вигорання. Діагностика $і$ профрілактика. СПб.: Пітер: Пітер принт.

4. Kwarta, P., Pietrzak, J. \& Miskowiec, D., et al. (2016). Personality traits and styles of coping with stress in physicians. Pol Merkur Lekarski, (40), 301-307.

5. Salvagioni, D. A. J., Melanda, F. N. \& Mesas, A. E., et al. (2017). Physical, psychological and occupational consequences of job burnout: a systematic review of prospective studies. PLoS ONE, (12), 9-16.

DOI 10.36074/25.10.2019.v2.11

\section{ОЦІНКА РІВНЮ ІНТЕРНЕТ-ЗАЛЕЖНОСТІ СТУДЕНТІВ ХАРКІВСЬКОГО НАЦІОНАЛЬНОГО МЕДИЧНОГО УHIBEРСИТЕТУ}

НАУКОВО-ДОСЛІДНА ГРУПА:

Герасименко Ольга Ігорівна канд. біол. наук, доцент кафедри гігієни та екології №1 Харківський національний медичний університет

Кателевська Наталія Миколаївна канд. мед. наук, доцент кафедри гігієни та екології №1 Харківський національний медичний університет

Богачова Ольга Сергіївна канд. мед. наук, асистент кафедри гігієни та екології №1 Харківський національний медичний університет УКPÄ̈HA

Актуальність. Активне використання інтернет-технологій сучасною молоддю являється невід'ємною характеристикою повсякденного життя. Звертаючи увагу на можливості, що надаються сучасними портативними та мобільними пристроями, розповсюдженістю та доступністю мережі Інтернет, особливості контенту Інтернет мереж, а також інтересу осіб молодого віку до соціальних мереж, виникає цілком обґрунтоване занепокоєння щодо можливості формування інтернет-залежності у даного контингенту. Окремі види інтернет-діяльності, а саме інтернет-ігри, вже визнані як патологічний стан [4]. Як зазначають вчені, надмірна увага, що приділяється використанню Інтернету, здатна не тільки впливати на психо-емоційний стан особливості та призводити до погіршення соціальної адаптації, а й призводити до формування як психічних, так і психосоматичних захворювань [1-3]. Тому своєчасне виявлення станів, що передують розвитку інтернет-залежності у осіб груп ризику, до яких відносяться студенти, є актуальним питанням сьогодення. 
Мета дослідження. Оцінка рівня поширеності інтернет-залежності серед студентів Харківського національного медичного університету та виявлення основних характеристик використання Інтернету.

Методи дослідження. Матеріалом для дослідження служив аналіз тестування 94 анкет-тестів на інтернет-залежність. Дослідження проводилось в Харківському національному медичному університеті за участю студентів 2 курсу медичного факультету. Для опитування використовувалася тестова методика Кімберлі Янг (адаптована та перекладена за В.О. Лоскутовою).

Результати дослідження. Розподілення студентів за кількістю набраних балів було наступним чином: більша кількість респондентів $(91,49 \%)$ не мають проблем з інтернет-залежністю, тому можуть вільно подорожувати по "Всесвітньому павутинню". Проте, 8,51 \% обстежених знаходяться на межі між умовно "здоровими" та "залежними" від мережі.

Аналіз відповідей на запитання тесту показав, що 26,60 \% опитаних часто, а $43,62 \%$ іноді проводять он-лайн значно більше часу, ніж планували. Водночас $45,74 \%$ іноді та $11,70 \%$ студентів часто нехтують домашніми справами, надаючи перевагу спілкуванню в Інтернеті. Така негативна тенденція служить передумовою формування залежності з централізацією використання інтернету за рахунок іншої діяльності. Про такі наслідки говорить результат відповіді на запитання щодо погіршення успіхів в роботі або навчанні у опитаних, а саме: 44,68 \% іноді відмічають такі наслідки, у 8,51\% вони регулярні, а у 7,45 \% - часті. Захоплення Інтернетом також не найкращим чином може впливати на самопочуття і працездатність людини, які в свою чергу залежать від повноцінного відпочинку організму. Досить велика кількість студентів віддають перевагу он-лайн розвагам замість повноцінного сну, а саме: по 7,44 \% часто та регулярно, 6,38 \% - завжди, 35,11\% - іноді. Через порушення психофрізіологічних норм з'являється втомлюваність, знижується розумова та фізична працездатність, страждає фрізичне здоров'я.

Висновки. За результатами дослідження було встановлено наявність специфічних особливостей, які за відсутності відповідної корекції здатні призводити до формування Інтернет залежності. Окремого занепокоєння викликає факт встановлення студентів, які за даними анкетування знаходяться у групі осіб на межі між умовно "здоровими" та "залежними" від інтернетмережі. Що обумовлює необхідність активного впровадження заходів 3 профрілактики інтернет-залежності та проведення відповідної корекції режиму використання Інтернету.

\section{Список використаних джерел:}

1. Cerniglia, L., Zoratto, F., Cimino, S., Laviola, G., Ammaniti, M. \& Adriani, W. (2017). Internet Addiction in adolescence: Neurobiological, psychosocial and clinical issues. Neurosci. Biobehav. Rev., (76), 174-184.

2. Kıng, D. L., Delfabbro, P. H., Kaptsıs, D. \& Zwaans, T. (2014). Adolescent simulated gambling via digital and social media: An emerging problem. Computers in Human Behavior, (31), 305-313.

3. Odaci H., \& Kalkan, M. (2010). Problematic Internet use, loneliness and dating anxiety among young adult university students. Computers \& Education, 55(3), 1091-1097.

4. Saunders, J. B. (2017). Substance use and addictive disorders in DSM-5 and ICD 10 and the draft ICD 11. Curr. Opin. Psychiatry, (30), 227-237. 


\title{
ПРИНЦИПИ ЛІКУВАННЯ ГРИБКОВИХ УРАЖЕНЬ СЛИЗОВОЇ ОБОЛОНКИ ПОРОЖНИНИ РОТА У ДІТЕЙ 3 ГОСТРИМИ ФОРМАМИ ЛЕЙКЕМІЙ
}

\begin{abstract}
НАУКОВО-ДОСЛІДНА ГРУПА:
Легенчук Оксана Володимирівна

Національний медичний університет імені О.О.Богомольця

Мозгова Олена Миколаївна

Національний медичний університет імені О.О.Богомольця

Воєвода Олена Олександрівна

Національний медичний університет імені О.О.Богомольця

УКРАЇHA
\end{abstract}

Вступ. В останні роки відмічають значне зростання грибкових уражень слизової оболонки порожнини рота $/ 25 \%-54 \%$ / серед хворих дітей на гострі лейкемії $[1,2]$. У дітей 3 гострими лейкеміями спостерігається розвиток не тільки поверхневих мікозів, але й глибоких фрорм ураження [3]. Переходу цих умовно-патогенних грибів у патогенні у хворих лейкеміями сприяють, насамперед, зміни імунної реактивності організму, порушення факторів гуморального та клітинного імунітету [4, 5]. Антибіотики, високодозна хіміотерапія індукують колонізацію та сприяють збільшенню вмісту грибів на слизовій оболонці порожнини рота.

Таким чином, інфекція, яку провокують гриби, відіграє значну роль у клінічному перебігу дітей з гострими лейкеміями. Вона може проявлятися на всіх етапах хіміотерапії госторого лейкозу, а також на фоні підтримуючого лікування, так як і в цьому періоді зберігається глибокий імунодефріцит $[6,7]$.

За даними літератури, при гострих лейкеміях інвазивні мікози виникають у 3-36\% хворих, при трансплантології кісткового мозоку - у 11-17\%. Основний відсоток мітотичної інфекції при нейтропеніях (більш ніж 70\%) обумовлений не тільки дріжжеподібними грибами, але й пліснявими [8].

Необхідно відмітити, що у останні роки відмічається ріст резистентності грибів практично до багатьох протигрибкових препаратів, тому призначення цих препаратів з метою лікування та профрілактики повинно базуватися на визначенні чутливості штамів грибів до протигрибкових препаратів $[9,10,11$, 12].

Тому, метою роботи є визначення чутливості різних видів грибів роду «Candida» та «Aspergillsus» до деяких протигрибкових препаратів у дітей 3 гострими формами лейкемій, та виявлення серед них найбільш ефрективних для лікування кандидозу.

Об єкт і методи дослідження. Нами було клінічно обстежено 29 дітей, віком від 3-х до 18-ти років з гострими формами лейкемій, які знаходились на лікуванні у відділенні дитячої гематології Київського обласного онкологічного диспансеру, Київській міській дитячій лікарні «ОХМАТДИТ» та у відділенні дитячої гематології Радіаційного центру м. Києва. Під час обстеження діти знаходились на різних етапах лікування, у яких було діагностовано кандидоз слизової оболонки порожнини рота. Діагноз був підтверджений як клінічними, 
так і лабораторними методами дослідження. Контрольну групу складали 25 дітей у віці від 3-х до 18-ти років, з гострими фрормами лейкемій. Гематологами призначалися препарати протигрибкової дії з метою профрілактики та лікування кандидозних уражень на фоні інтенсивної хіміотерапії без попередніх досліджень визначення чутливості грибів до цих протигрибкових препаратів.

3 метою визначення чутливості дріжджоподібних грибів та грибів роду «Aspergillsus» у виділених хворих на гострі лейкемії до протигрибкових засобів використовували систему Fungitest $®$ («Sanofi Diagnostics Pasteur», Франція). Для цього по дві ізольовані колонії грибів роду «Candida», вирощенні протягом 24 год., на селективному середовищі Сабуро, бактеріологічною петлею вносили у стерильний флакон з 10,0мл дистильованої води і перемішували до утворення гомогенної суспензії. Таким чином, отримували перший калібрований інокулят, який відповідав стандарту еквівалента мутності Мас Farland №1 (близько 10 дріжджоподібних клітин на 1 мл). Інокулятом слугувало розведення 1/10 цієї суспензії (20 краплин суспензії із пас терки $/ 1$ мл/ на 9 мл стерильної дистильованої води), тобто 10 дріжджоподібних клітин на 1 мл.

Для грибів роду «Aspergillsus» відбирається інокулят після 5-ої доби калібровочною петлею із спорилірованої культури, який вносили у 10 мл дистильованої води. Спориліровану культуру вирощували на агарі Сабуро + хлорамфенікол при $37^{\circ} \mathrm{C}$ (зелена культура). Потім розведену грибкову культуру в кількості 100 мкл вносили в комірки мікропланшети системи Fungitest, на поверхню якої за допомогою пінцету накладували антифугальні диски. На казитоновому середовищі розміщували диски з слідуючими препаратами: амфотеріцин В, ністатин, еконазол, клотримазол, міконазол, кетоконазол. Чутливість до 5-фрлюороцитозину тестується на напівсинтетичному середовищі: диски 1 мкг та 5-фрлюороцитозин 10 мкг. Мікропланшети інкубували в термостаті при $37^{\circ}$ С протягом 24 год. Інтерпретацію результатів проводили за допомогою визначення діаметру зони росту інгібіції в мм. Таким чином, визначали чутливі, проміжні та резистентні препарати до грибів [13].

При визначенні чутливості грибів роду "Candida» до препарату рослинного походження настою богульника болотного брали 2 столові ложки трави, які заливали 1 стаканом окріпу (200мл) та кип`ятили 15-20 хв. Потім настій проціжувався та досліджувалась антимікотична дія настою. Дослідження проводили згідно модифікації методики ДФУ (2001), при якій настій богульника болотного розводили у два рази м'ясопептонним бульйоном та добавляли суміш «Candida albicans» в концентрації $10^{3}$. У кількісному відношенні це виражалось: 5мл настою богульника + 5 мл МПБ +0,1 мл суміші «Candida albicans». В якості контролю замість настою богульника болотного використовували стерильний фізіологічний розчин [14].

Результати дослідження та їх обговорення. За даними наших досліджень, у 86\% дітей з гострими формами лейкемій діагностовано кандидоз різного ступеню тяжкості. При аналізі історій хвороб у даного контингенту дітей нами було виявлено, що в процесі лікування лікарями - гематологами призначались протигрибкові препарати - флюконазол, ністатин, амфотерицин, ффунгізон. При опитуванні ми виявили, що 17-ми дітям був призначенний дифлюкан (флюконазол) по 1 табл. 3 рази на день після їжі, амфотерицин-В (фунгізон) приймали 16 дітей та ністатин - 13 дітей, 10 дітей приймали 5- фрлюороцитозин. Дві дитини не приймали протигрибкових 
препаратів (знаходились на етапі ремісії). Вони не мали вираженої клінічної картини кандидозу, але при мікробіологічному методі дослідження у них були виявлені гриби Candida albicans - 1500 колоній утворюючих одиниць (КУО), Candida tropicalis - 4000 КУО на один тампон. Тому визначення чутливості штамів грибів до протигрибкових препаратів у цих дітей не проводилось.

При вивченні чутливості штамів грибів до препарату дифрлюкан (фолюконазол) було визначено, що із 17-ти дітей, що приймали цей препарат, у 14 хворих штами грибів були чутливі до нього, а у трьох - не чутливі. При призначенні амфотерицину - В (фунгізон) із 16 - ти дітей тільки у однієї дитини штами грибів були чутливі до дії цього препарату, а у 15-ти хворих - не чутливі. При визначенні чутливості штамів грибів до ністатину із 13-ти дітей, яким він призначався, штами грибів були чутливі у двох із них. У одної дитини, яка приймала 5-фрлюороцитозин, штами грибів були не чутливі до цього препарату. У одної дитини, яка не приймала протигрибкові препарати, штами грибів були чутливі до флюконазолу, ністатину, клотримазолу, фуунгізону, кетоконазолу та міконазолу, а не чутливі до 5-фрлюороцитозину, еконазолу. У другої дитини чутливі до фрлюконазолу, ністатину, фрунгізону, кетоконазолу та міконазолу, 5-флюороцитозину, не чутливі до еконазолу та клотримазолу. При аналізі результатів чутливості штамів грибів до протигрибкових препаратів ми визначили, що із 29 хворих дітей штами грибів були чутливі до флюконазолу у 22 дітей, 5 - флюороцитозину - 26 хворих, ністатину - 18 , еконазолу - 19, клотримазолу - 20, амфотерицину - 21, кетоконазолу 29 i міконазолу у 26 дітей (табл. 1).

Чутливість виділених штамів грибів до деяких протигрибкових Таблиця 1 препаратів у дітей з гострими лейкеміями

\begin{tabular}{|c|c|c|}
\hline \multirow{2}{*}{ Препарат } & \multicolumn{2}{|c|}{ Чутливість штамів грибів } \\
\cline { 2 - 3 } & Чутливі & Нечутливі \\
\hline Флюконазол & 22 & 7 \\
\hline 5-фрлороцитозин & 26 & 3 \\
\hline Ністатин & 18 & 11 \\
\hline Еконазол & 19 & 10 \\
\hline Клотримазол & 20 & 9 \\
\hline Амфотерицин & 21 & 0 \\
\hline Кетоконазол & 29 & 3 \\
\hline Міконазол & 26 & 8 \\
\hline
\end{tabular}

Таким чином, за нашими даними, ми вважаємо обов 'язковим визначення чутливості виділених штамів грибів до протигрибкових препаратів, що $\epsilon$ важливим при проведенні профілактики та лікування кандидозу у даного контингенту дітей. Найбільш доцільним, на наш погляд $є$ призначення кетоконазолу, міконазолу, 5-фрлюороцитозину, амфотерицину. Найменша чутливість була виявлена до клотримазолу, еконазолу та ністатину.

Перспективи подальших досліджень полягають у необхідності подальшого вивчення особливостей клінічного перебігу різних форм кандидозів у дітей з гострими формами лейкемій.

\section{Список використаних джерел:}

1. Павлова, М. Л. (2012). Лейкозы у детей (клинико-радиологические исследования). Высшая школа, 384. 
2. Казначеев, К. С. (2012). Мукозиты ротовой полости у детей с острым лейкозом. Вопросы детской диетологии, Т.10, (1), 69-72.

3. Борис, С. П., Попруженко, Т. В., Морейко, Ю. Е. \& Гущина, Л. М. (2013). Оральный мукозит у детей при лечении острого лимфобластного лейкоза методом трансплантации гемопоэтических стволовых клеток. Мед.журн., (3), 55-55.

4. Попруженко, Т. В., Углова, Т. А. \& Борис, С. П. (2011). Современное состояние химиотерапевтического орального мукозита. Соврем. стоматология, (2), 14-20.

5. Попруженко, Т. В., Борис, С. П. \& Красько, О. В. (2017). Факторы иммунитета в патогенезе химиотерапевтического орального мукозита у детей. Медицина, (1), 47-49.

6. Бабий, И. Л. \& Калашникова, Е. А. Болезни слизистой оболочки, кандидозные поражения полости рта у детей, (Ч. 1). Здоров'я дитини, 3(12).

7. Борис, С. П., Попруженко, Т. В. \& Красько, О. В. (2016). Факторы риска развития химиотерапевтического мукозита у детей и подростков, связанные с особенностями организма пациентов и основного заболевания. Современная стоматология, (4), 66-70.

8. Алиева, М. Д., Полякова, В. Г., Менткевича, Г. Л. \& Маяковой, С. А. (2012). Детская онкологи. М.: Издательская группа РОНЦ.

9. Легенчук, О. В., Мозгова, О. М. \& Волкова, С. В. (2017). Індивідуальні засоби гігієни порожнини рота у дітей з гострими формами лейкемій. Вісник проблем біології та медицини 2017, Bun. 4, T. 3, (141), 349-352.

10. Ковач, И. В., Хотимская, Ю. В., Хотимский, Б. Л. \& Гаспарян, О. Р. (2016). Гигиенический статус детей, больных острыми формами лейкемии. Современная стоматология, (4), 2830.

11. Борис, С. П. \& Попруженко, Т. В. (2014). Бактериальная микрофлора полости рта и химиотерапевтический мукозит при лечении острого лимфобластного лейкоза у детей. Интегративная медицина в челюстно-лицевой хирургии и стоматологии: сб. тр. науч.практ. конф. с междунар. участием «Паринские чтения 2014» (с. 382-384), 10-11 апр. 2014 г. Минск, Беларусь.

12. Савичук, Н. О. (2012). Эффективность методов комплексной терапии хронической кандидагерпетической инфекции полости рта у детей. Современная стоматология, (4), 79-79.

13. Drouhet, E. and al. (2013). Standardization of the antifungal sensitivity tests. Report of the French Society for Medical Mucology, Mucology. Bull. Soc. Fr. Mycol. Med., 10(1), 131-134.

14. Drouhet, E. \& Dupont, B. (2014). Sensitivity of fungi to antifungal compounds. Bull. Soc. Fr. Mycol. Med., (7), 165-170.

\section{ПСИХО-ЕМОЦІЙНИЙ СТАН ПАЦІЄНТІВ-ПІДЛІТКІВ 3 ЦУКРОВИМ ДІАБЕТОМ I ТИПУ}

Сухарєва Лілія Павлівна

здобувач вищої освіти медичного факультету Харківський національний медичний університет

Кателевська Наталія Миколаївна канд. мед. наук, доцент кафедри гігієни та екології №1 Харківський національний медичний університет

УКРАÏHA

Актуальність. Психо-емоційний стан пацієнтів-підлітків має важливе значення при виборі стратегії лікування цукрового діабету I типу. В багатьох 
випадках негативний емоційний фон значною мірою погіршує стан пацієнтів. Окремого занепокоєння викликає ставлення оточуючих до молодих людей, які страждають на сахарний діабет. Так, постає питання обмеження соціальних контактів, дискримінації з боку однолітків, зайва увага до неможливості підтримувати загальносуспільні тенденції стилю життя молоді. Крім того, підліткам з цукровим діабетом вимушено доводиться звикати до необхідності переходу до «дорослої» системи медичної допомоги та постійного амбулаторного контролю [1].

Як свідчать наукові дані, проблема цукрового діабету наразі $€$ однією 3 найбільш значущих. За світовими даними на це захворювання страждає понад 371 млн осіб. Тобто біля 7\% населення земної кулі. Кожного року діагноз цукрового діабету I типу реєструється у 70 тис. підлітків віком від 14 років. Кожного року зростання кількості людей, що захворіли на цукровий діабет становить 3\%. За прогнозами вчених за 6 років кількість осіб, які страждають від даного захворювання, збільшиться у два рази [2].

Особливості психо-емоційного стану молодих осіб, які мають даний діагноз, здебільшого формуються однолітками, для яких $є$ типовим упереджене ставлення до цього контингенту хворих.

Мета роботи. Аналіз психо-емоційних особливостей пацієнтів-підлітків 3 цукровим діабетом I типу, а також виявлення факторів ризику, що здатні призводити до психо-емоційних розладів.

Матеріали та методи. Дослідження було проведено за допомогою тестових методик оцінювання якості життя з використанням опитувальника PedsQL. Y досліджуванні прийняло участь 30 молодих осіб віком від 14 до 18 років, яким встановлено діагноз цукрового діабету I типу.

Результати дослідження. Аналіз відповідей дозволили встановити, що лише 30\% осіб досліджуваної групи не відчувають підвищеної тривожності. При цьому зниження настрою і фрізичної активності спостерігається у 45\% анкетованих, 30\% - звертають увагу на негативну реакцію однолітків. У $20 \%$ осіб, які прийняли участь в анкетуванні, відчувається погіршення самопочуття після спілкування з однолітками.

Висновок. Психо-емоційний стан є важливим фактором, здатним впливати на соматичний стан, молодої особи, яка хвора на цукровий діабет I типу. При цьому стан підвищеної тривожності займає пріоритетну позицію серед несприятливих психосоціальних чинників навколишнього середовища. Таким чином, постає питання своєчасності та доцільності впровадження поетапної системи психокорекції з метою поліпшення якості життя пацієнтів з діабетом I типу та підвищення ефективності лікування.

\section{Список використаних джерел:}

1. Bernstein, C. M., Stockwell, M. S., Gallagher, M. P., Rosenthal, S. L. \& Soren, K. (2013). Mental health issues in adolescents and young adults with type 1 diabetes: Prevalence and impact on glycemic control. Clinical Pediatrics (Philadelphia), (52), 10-15.

2. Davidson, M., Penney, E. D., Muller, B. \& Grey, M. (2004). Stressors and self-care challenges faced by adolescents living with type 1 diabetes. Appl Nurs Res, (17), 72-80. 


\section{SECTION VII. \\ PHARMACY}

\section{ОПЫТ И ПЕРСПЕКТИВЫ ИСПОЛЬЗОВАНИЯ ЛЕКАРСТВЕННЫХ РАСТЕНИЙ ДЛЯ ЛЕЧЕНИЯ ИШЕМИЧЕСКОЙ БОЛЕЗНИ СЕРДЦА}

НАУЧНО-ИССЛЕДОВАТЕЛЬСКАЯ ГРУППА:

Столетов Юрий Витальевич

кандидат биологических наук

Национальный фрармацевтический университет

Куценко Татьяна Александровна

кандидат фрармацевтических наук

Национальный фрармацевтический университет

Уланова Вера Анатольевна

кандидат фармацевтических наук

Национальный фрармацевтический университет

Белик Галина Владимировна

кандидат фрармацевтических наук

Национальный фармацевтический университет

УКРАИНА

Проблема лечения заболеваний сердечно-сосудистой системы, в том числе, ишемической болезни сердца (ИБС) и наиболее её частого проявления стенокардии, является актуальной в настоящее время. Последствия, которые вызывает данное заболевание, могут привести, как к потере работоспособности, так и смерти больного. Исходя из важности проблемы на сегодня имеется огромный арсенал лекарственных средств для лечения ИБС. Базовыми препаратами являются антиангинальные средства, которые представлены современными и эфрфективными лекарствами.

Большинство из этих препаратов, в том числе, самые эффективные из них нитраты и препараты нитратоподобного действия, селективные блокаторы медленных кальциевых каналов, блокаторы бета-адренорецепторов, имеют много побочных эфффектов $[1,2,3,4,5]$.

С учетом того, что эти препараты больному приходится применять длительно, их побочное действие существенно осложняет проведение эффрективной фрармакотерапии. Поэтому врачу время от времени приходится проводить замену препаратов, которые вызывают осложнение, на другие более безопасные.

Перспективными объектами в плане выхода из сложившейся ситуации могут стать препараты на основе лекарственных растений. Известно, что лекарственные растения достаточно широко используются для лечения ИБС в народной медицине $[2,4,6,7,12,16]$. Однако, следует обратить внимание, что такие растения, как боярышник кроваво-красный, валериана 
лекарственная, ландыш майский, некоторые виды наперстянок, пустырник обыкновенный довольно давно, также применяют и в официальной медицине для лечения ИБС. При этом, согласно данным литературы и интернетресурсов, мало востребованными остаются многие другие лекарственные растения, которые обладают необходимыми для лечения ИБС фармакологическими эфффектами [7, 8, 9, 10, 16]. Лекарственные растения, естественно не претендуют на полную замену синтетических базисных лекарственных препаратов, но они могут быть хорошим дополнением для них. Также трудно переоценить, какое значение имеет применение препаратов растительного происхождения для профилактики ИБС.

Целью нашей работы стал анализ имеющихся данных литературы и интернет ресурсов для выяснения возможности более широкого использования лекарственных растений для профилактики и лечения ИБС.

Как хорошо известно, ИБС - хронический патологический процесс, обусловленный недостаточностью кровоснабжения миокарда, в подавляющем большинстве случаев является следствием атеросклероза и/или тромбоза, реже функционального спазма, коронарных артерий. Исходя из особенностей патогенеза данного заболевания, основными задачами, которые необходимо решать при лечении ИБС, являются следующие:

-улучшение кровоснабжения миокарда и других тканей и органов;

-нормализация содержания в крови липидов (холестерина), триглицеридов, липопротеидов высокой плотности, липопротеидов низкой плотности, липопротеидов очень низкой плотности;

-снижение артериального давления и регуляция сосудистого тонуса;

-поддержание нормальных показателей свертывания крови;

-оптимизация энергетических и пластических процессов в миокарде;

-обеспечение оптимального водного и солевого баланса;

- успокаивающее (седативное) воздействие на ЦНС при необходимости;

-профилактика осложнений.

В ходе проведения анализа данных литературы и интернет-ресурсов нами было найдено достаточно много лекарственных растений, которые можно применять для лечения ИБС. Лекарственные растения и особенности их фармакологической активности представлены в таблице 1.

Таблица 1

Лекарственные растения и их фармакологические эфффекты, которые используют для лечения ИБС

\begin{tabular}{|c|c|c|c|c|c|c|c|c|}
\hline \multirow[b]{2}{*}{$\begin{array}{l}\text { Растение, его } \\
\text { сырье }\end{array}$} & \multicolumn{8}{|c|}{ Фармакологические эффекты } \\
\hline & 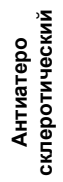 & 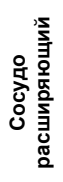 & 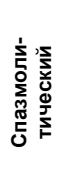 & 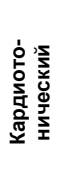 & 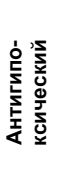 & 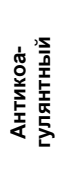 & 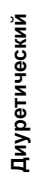 & 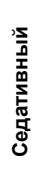 \\
\hline $\begin{array}{l}\text { Адонис весенний, } \\
\text { трава }\end{array}$ & & & & + & & & + & + \\
\hline $\begin{array}{l}\text { Аир болотный, } \\
\text { корневище }\end{array}$ & & + & & & & & + & + \\
\hline
\end{tabular}


Продовження табл. 1

\begin{tabular}{|c|c|c|c|c|c|c|c|c|}
\hline \multirow[b]{2}{*}{$\begin{array}{c}\text { Растение, его } \\
\text { сырье }\end{array}$} & \multicolumn{8}{|c|}{ Фармакологические эффекты } \\
\hline & 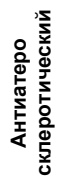 & 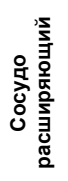 & 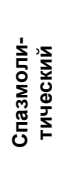 & 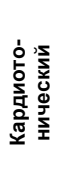 & 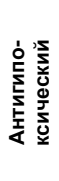 & 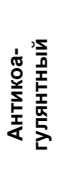 & 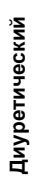 & 焉 \\
\hline $\begin{array}{l}\text { Арника горная, } \\
\text { соцветия }\end{array}$ & + & + & & & + & & & + \\
\hline $\begin{array}{l}\text { Багульник } \\
\text { болотный, побеги }\end{array}$ & & + & & & & & & + \\
\hline $\begin{array}{l}\text { Барвинок малый, } \\
\text { трава }\end{array}$ & & + & + & & & & & + \\
\hline $\begin{array}{l}\text { Белокопытник } \\
\text { обыкновенный, } \\
\text { листья }\end{array}$ & & & + & & & + & + & \\
\hline $\begin{array}{l}\text { Береза белая, } \\
\text { листья, почки, сок }\end{array}$ & + & + & + & & + & & + & \\
\hline $\begin{array}{l}\text { Бессмертник } \\
\text { песчаный, цветы }\end{array}$ & + & & + & & & & + & + \\
\hline $\begin{array}{l}\text { Боярышник крова- } \\
\text { красный, цветы, } \\
\text { плоды, листья }\end{array}$ & + & + & + & + & + & + & + & + \\
\hline $\begin{array}{l}\text { Брусника } \\
\text { обыкновенная, } \\
\text { листья, плоды }\end{array}$ & + & + & + & & + & & + & \\
\hline $\begin{array}{l}\text { Бузина черная, } \\
\text { цветы }\end{array}$ & & + & & & + & & + & \\
\hline $\begin{array}{l}\text { Валериана } \\
\text { лекарственная, } \\
\text { корневище } \\
\text { корнями }\end{array}$ & & + & + & & & & + & + \\
\hline $\begin{array}{l}\text { Вереск } \\
\text { обыкновенный, } \\
\text { трава }\end{array}$ & & & + & & & & + & + \\
\hline $\begin{array}{l}\text { Донник } \\
\text { лекарственный, } \\
\text { трава }\end{array}$ & & + & + & & + & + & & + \\
\hline $\begin{array}{l}\text { Душица } \\
\text { обыкновенная, } \\
\text { трава }\end{array}$ & + & & + & & & & + & + \\
\hline $\begin{array}{l}\text { Желтушник серый, } \\
\text { трава }\end{array}$ & & + & + & + & & & + & \\
\hline $\begin{array}{l}\text { Земляника лесная, } \\
\text { листья, плоды }\end{array}$ & + & + & + & & & + & + & \\
\hline $\begin{array}{l}\text { Календула } \\
\text { лекарственная, } \\
\text { цветы }\end{array}$ & & & + & & & + & + & + \\
\hline $\begin{array}{l}\text { Каштан конский, } \\
\text { плоды }\end{array}$ & + & + & + & & & + & & \\
\hline $\begin{array}{l}\text { Ландыш майский, } \\
\text { цветы }\end{array}$ & & & + & + & & & + & + \\
\hline $\begin{array}{l}\text { Лимонник } \\
\text { китайский, плоды, } \\
\text { листья }\end{array}$ & & & & + & + & & & \\
\hline
\end{tabular}


- Scientific discoveries: projects, strategies and development $\bullet$ Volume 2

Продовження табл. 1

\begin{tabular}{|c|c|c|c|c|c|c|c|c|}
\hline \multirow[b]{2}{*}{$\begin{array}{l}\text { Растение, его } \\
\text { сырье }\end{array}$} & \multicolumn{8}{|c|}{ Фармакологические эффекты } \\
\hline & 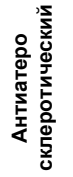 & 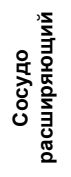 & 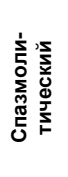 & 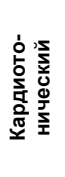 & 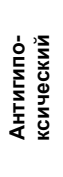 & 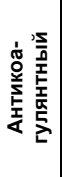 & 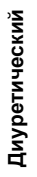 & 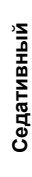 \\
\hline $\begin{array}{l}\text { Липа } \\
\text { сердцевидная, } \\
\text { цветы }\end{array}$ & & & + & & + & & + & \\
\hline $\begin{array}{l}\text { Мелисса } \\
\text { лекарственная, } \\
\text { трава }\end{array}$ & & + & + & & + & & & + \\
\hline $\begin{array}{l}\text { Наперстянка, } \\
\text { листья }\end{array}$ & & & & + & & & + & \\
\hline $\begin{array}{l}\text { Одуванчик } \\
\text { лекарственный, } \\
\text { листья, корни }\end{array}$ & + & & & & + & & + & + \\
\hline $\begin{array}{l}\text { Пустырник } \\
\text { обыкновенный, } \\
\text { трава }\end{array}$ & & + & + & + & & & + & + \\
\hline $\begin{array}{l}\text { Рябина } \\
\text { обыкновенная, } \\
\text { цветы, плоды }\end{array}$ & + & + & & & + & & + & \\
\hline $\begin{array}{l}\text { Солодка голая, } \\
\text { корни }\end{array}$ & & + & + & & + & & + & + \\
\hline $\begin{array}{l}\text { Сушеница } \\
\text { топяная, трава }\end{array}$ & & & + & & + & & + & + \\
\hline $\begin{array}{l}\text { Хвощ } \\
\text { трава }\end{array}$ & + & & + & & + & & + & \\
\hline $\begin{array}{l}\text { Черника } \\
\text { обыкновенная, } \\
\text { плоды, листья }\end{array}$ & & & + & & + & & + & \\
\hline $\begin{array}{l}\text { Чистотел } \\
\text { большой, трава }\end{array}$ & & + & + & & + & & + & \\
\hline
\end{tabular}

Выше мы указали основные задачи, которые необходимо решать при лечении ИБС. Ими необходимо руководствоваться при подборе лекарственных растений и составлении фитосборов. При этом необходимо учитывать основные виды действия лекарственных растений (табл.1).

Антиатеросклеротическое действие лекарственных растений направлено на выведение из организма холестерина и атерогенных липопротеидов. В конечном итоге это приводит к снижению атерогенных факторов в сыворотке крови, а вероятность атеросклероза и темпы его прогрессирования снижаются. Известно большое количество растений с антиатеросклеротическим действием. Например, чеснок, трава тысячелистника, корни одуванчика и др. (табл.1).

Сосудорасширяющее действие, как правило, приводит к гипотензивному эфффекту. Оно может использоваться при сочетании ИБС и гипертонии. Как видно из данных таблицы, способностью расширять сосуды обладают многие лекарственные растения. Из них наиболее известны трава сушеницы топяной, донника лекарственного, плоды рябины черноплодной и боярышника и 
некоторые другие. Спазмолитическое действие чаще всего не дает выраженного гипотензивного эффекта. Растения, которые обладают данным действием (табл.1) можно использовать для уменьшения спазма артерий, например, мозговых, коронарных, нижних конечностей. Следствием действия таких растений является улучшение регионарного кровоснабжения, в том числе и сердца, что важно для лечения ИБС [2, 4, 12, 13, 15].

Кардиотоническое действие лекарственных растений можетприменяться, когда по целому ряду причин сила сердечных сокращений падает. Например, при атеросклерозе или рубцах после инфаркта миокарда. Как видно из таблицы, имеется достаточное количество растений, которые обладают кардиотоническим действием. Это горицвет весенний, ландыш майский, боярышник кроваво-красный и другие. Нужно помнить, что использовать лекарственные растения с кардиотоническим действием необходимо под наблюдением врача $[2,4,11,16]$.

Антигипоксическое действие оказывают многие растения. Данное действие повышает устойчивость организма к кислородному голоданию и уменьшает его отрицательное воздействие на органы и ткани. Использование таких растений (таблица 1) в сборах повышает их эффективность и может быть использовано при лечении ИБС и сопутствующего ей атеросклероза [2, 4, 11].

Антикоагулянтное действие лекарственных растений используют чаще всего для профилактики тромбоэмболических осложнений, которые часто встречаются при ИБС. Из лекарственных растений наиболее известен донник лекарственный, действующим веществом которого являются кумарины. Также известно, что в листьях боярышника кроваво-красного содержатся эти соединения. Кора ивы белой содержит спирт салигенин, который в организме окисляется в салициловую кислоту. Салицилаты в свою очередь, обладают антиагрегантным действием [2, 4, 14, 15, 16].

Диуретическое действие является одним из наиболее распространенных эффектов лекарственных растений, многие из которых безопасны для организма. Кроме того, они не так интенсивно, как большинство синтетических препаратов, выводят из организма ионы калия, которые необходимы для нормальной работы сердца. Диуретическое действие лекарственных растений не так сильно, как у классических препаратов, но достаточно стабильно. Использование фитосборов (табл.1) поможет больному стабилизировать повышенное артериальное давление, уменьшить отечность $[2,4,12,15,16]$.

Седативное действие, которое оказывают лекарственные растения отличается также стабильностью и мягкостью. Сборы лекарственных растений показаны в тех случаях, когда отмечаются нарушения сна, стрессовые ситуации и другие состояния, которые способствуют активации ЦНС и могут негативно сказаться на работе сердечно-сосудистой системы [2, 4, 12].

Подводя итог, можно отметить, что возможности фитотерапии велики, но не безграничны. Широкие возможности выбора, взаимозаменяемость и хорошая переносимость позволяют применять фитосборы длительное время. Этим они выгодно отличаются от синтетических средств [2, 7, 13, 14, 15, 16]. 
Биологически активные вещества растений действуют верно, но относительно медленно. Они не могут с такой же быстротой купировать боли при стенокардии, как нитроглицерин. Однако, фритотерапия эфффективна в начальной стадии заболевания или при умеренной клинической симптоматике. Большое значение она имеет для профилактики. Фитотерапия способна помочь основной терапии, в период завершения курса лечения может обеспечить преемственность лечения. При комбинации с синтетическими препаратами способствует уменьшению дозировок последних и нивелируют часть побочных эффектов.

Выводы:

1. Имеется большое количество лекарственных растений, которые благодаря наличию необходимых фармакологических эффектов можно применять для лечения ИБС.

2. Лекарственные растения в отличие от синтетических препаратов, применяемых для терапии ИБС, имеют меньше побочных эфрфектов и обладают хорошей переносимостью.

3. С учетом того, что лекарственные растения имеют широкий спектр фармакологической активности целесообразно проводить лечение сборами лекарственных растений.

4. Преимущества фритосборов состоят в том, что они могут включать различные комбинации растений и вариантов этих комбинаций очень много.

5. Нецелесообразно проводить фитотерапию сборами малого состава. Как правило, результативны сборы состоящие из 8-10 растений.

6. Лечение фитосборами необходимо проводить длительно, при этом лечение одним сбором не должно превышать 2-3 месяцев.

7. При лечении фритосборами больной должен придерживаться необходимой диеты и комплекса других оздоровительных мероприятий.

8. Углубленное изучение и введение применяющихся при ИБС в народной медицине лекарственных растений в клиническую практику (включая, возможно, создание на их основе новых фритопрепаратов) является перспективным и целесообразным.

\section{Список использованных источников:}

1. Бут, Г. (2004). Еще раз об атеросклерозе. Ліки України, (11), 9-11.

2. Гажев, Б. Н., Виноградова, Т. А., Мартынов, В. К. \& Виноградов, В. М. (1996). Лечение атеросклероза и ишемической болезни сердца. СПб: ИКФ «МиМ экспресс».

3. Гоменюк, Г. А., Даниленко, В. С., Гоменюк, И. Г. \& Гоменюк, Т. Г. (2006). Энциклопедия практичной фитотерапии (Практическое применение 4260 рецептов лекарственных растений). Київ: ДСГ Лтд.

4. Кукеса, В.Г.(ред.). (1999). Фитотерапия с основами клинической фармакологии. М.: Медицина.

5. Дроговоз, С. М., Гудзенко, А. П., Бутко, Я. А. \& Дроговоз, В. В. (2010). Побочное действие лекарств: учебник-справочник. Харьков.

6. Блехер, Л. Б. \& Колосова, Т. И. (1992). Лечебное применение лекарственных растений и приготовление препаратов в домашних условиях. Санкт-Петербург.

7. Лавренова, В. К. \& Лавренова, Г. В. (2009). Современная энциклопедия лекарственных растений. М.: Олма Медиа Групп. 
8. Носов, А. М. (2000). Лекарственные растения. М.: ЭКСМО-Пресс.

9. Яковлева, Г. П. \& Блинова, К. Ф. (ред.). (1996). Растения для нас. Справочное пособие. Изд-во «Учебная книга».

10. Задорожный, А. М. (авт.-сост.). (2001). Травы и здоровье. лекарственные растения. Махаон: Гамма Пресс 2000.

11. Рыжская, В. (сост.). (2010). 100 самых популярных лечебных растений. Донецк: Мультипресс.

12. Чекман, И. С. \& Липкин, Г. Н. (1993). Растительные лекарственные средства. Киев: Колос. ИТЭМ.

13. Сас, І. А., Грицик, Л. М., Нейко, О. В. \& Грицик, А. Р. (2014). Розповсюдження, заготівля та раціональне використання лікарських рослин. Івано-Франківськ: ЛІК.

14. Ефремов, А. П. \& Шретер, А. И. (1996). Травник для мужчин. М.: Асадаль.

15. Носаль, М. А. \& Носаль, И. М. (1991). Лекарственные растения и способы их применения в народе. Львів.

16. Тайс, Б. \& Тайс, П. (1994). Лекарственные травы - путь к здоровью. (Р. Орлова, пер. с нем.). Санкт-Петербург. 


\section{SECTION VIII. \\ PSYCHOLOGY AND SOCIOLOGY}

DOI 10.36074/25.10.2019.v2.13

NEUROBIOLOGY OF POSTTRAUMATIC STRESS DISORDER

Alina Kyselova
student of the Department of Psychology in English (BA program)
SWPS University of Social Sciences and Humanities
REPUBLIC OF POLAND
Ekaterina Chernishova
student of the Department of Medicine
Dnipropetrovsk Medical Academy

UKRAINE

Introduction.

In our modern world people often deal with traumatic events: the loss of a home pet, the loss of a job, robbery, a car accident, natural disasters, severe illness, the death of a beloved person, etc. If we look at statistic data one out of two persons will be exposed to a life-threatening event during lifetime [1]. Unfortunately, but after experiencing such horrible events people tend to develop Post-Traumatic Stress Disorder (PTSD).

It is associated with an extreme response to a severe stressors, such as recurrent memories which are linked to the traumatic event, and avoidance of stimulus associated with trauma, negative thoughts and emotions, etc. Interestingly, after patients are diagnosed with PTSD there are some changes in their brain which are linked to the main symptoms of this disorder. And in this article, we would like to present a brief description of symptoms of PTSD and neurobiological picture of this disorder.

Methods and materials.

To write this article we reviewed NNN scientific articles, chapters from textbooks and Internet sources which are related to the main topic of this article.

Discussion and results.

According to Diagnostic and Statistical Manual of mental disorders all symptoms which are connected with PTSD are grouped into four categories:

1. Intrusively re-experiencing the traumatic event. Psychologists and psychiatrists mention that patients with PTSD usually have dreams or even nightmares about the traumatic situation night after night. Some of them can experience intrusive and painful memories, which are often evoked by small sensory cues. These sensory reminders can bring on a wave of psychophysiological arousal. The most common symptoms from this category are (at least one symptom must be present to be diagnosed with PTSD):

- recurrent, involuntary, and intrusive distressing memories of the trauma, or in cases of children, repetitive play regarding the trauma;

- recurrent distressing dreams linked to the event; 
- dissociative reactions, like a flashbacks, in which patient feels and/or act as if the trauma was recurring, or in cases of children, reenactment of trauma during play;

- prolonged or intense distress and/or physiological reactivity in response to reminders of the trauma.

2. Avoidance. Patients usually avoid stimuli which are linked to traumatic event. They try to avoid thinking about this event and all reminders (both internal and external) of trauma.

3. Negative alterations in cognitions and mood. These symptoms always develop after the trauma. Patients think that there is nothing what can bring joy in their life. In addition, some of them can start to blame themselves about the event (namely, they think that they are bad). On the other hand, some patients can develop a belief that other people are untrustworthy. The most common symptoms from this category are (at least two symptoms must be present to be diagnosed with PTSD):

- inability to remember some important characteristics of the trauma;

- persistent excessive blame of self or others linked to the traumatic event;

- persistent and/or exaggerated negative belief or expectations concerning one's self, other people, and/or the whole world;

- persistent negative emotional state. Children who are younger than 7-yearold, can experience negative emotions more frequently;

- decreased interest in favorable activities;

- feeling of detachment from other people. In cases of children who are younger than 7-year-old, social withdrawal is present;

- persistent inability to experience positive emotions.

4. Increased arousal and reactivity. Patients with PTSD usually feel continuously on a guard, and monitor the environment for a danger. The most common symptoms from this category are (at least two symptoms must be present to be diagnosed with PTSD):

- irritability and/or aggression;

- hypervigilance;

- reckless and/or self-destructive behavior;

- sleep problems;

- problems with concentration;

- exaggerated startle response.

Unfortunately, but if symptoms occur soon after the traumatic event, they will not disappear and become chronic.

If we look at the brain structure, we see the connection between PTSD and the function of the hippocampus. Due to the fact that it plays an essential role in autobiographical memories in time, context and space, it is not a big surprise that patients with PTSD have some changes associated with this part of the brain. It was shown that those patients have a smaller volume of the hippocampus in comparison to people without this disorder. In addition, people who are not diagnosed with PTSD but have a smaller volume of the hippocampus, have more chances to develop this disorder in the future.

Interestingly, patients who have PTSD have intense memories concerning smells, sounds, and other sensory stimuli. However, they have problems with 
organizing all those memories in a one narrative story. Moreover, it was shown that patients have deficits on neuropsychological tests of verbal memory, and on the other hand, they do not have any problems with solving tests linked to visual memory.

Focusing on the amygdala, we cannot see significant structural changes, but the activity of it is increased. This changes in activity leads to increased reaction to different stressful stimuli, even if it is neutral.

As the medial prefrontal cortex, there is a decreased reactivity which is correlated with the severity of symptoms (namely, problems with controlling of stress responses and decreased emotional reactions). Finally, there are some changes in sensorimotor cortex which are linked to the reactivity from this part of the brain (namely, hyperarousal during the influence of the traumatic stimulus).

Focusing on neurochemical changes which occurs after PTSD, some abnormal regulations in catecholamine, serotonin, amino acids, peptide and opioid neurotransmitters are found. According to recent studies, patients with have increased levels of dopamine (DA) and norepinephrine (NE) which can be responsible for the physiological effects which are linked to PTSD (e.g.s increased pulse and blood pressure, startle response and levels of arousal). On the other hand, patients have decreased level of serotonin which can influence the dynamic connection between amygdala and hippocampus (namely, abolishing its capacity to reduce anxiety and contributing to increased vigilance, impulsivity and intrusion of memories). In addition, according to several studies, there is a decreased level of gamma-Aminobutyric acid (GABA) among PTSD patients which clearly explain restricted ability to deal with stress and anxiety. On the other hand, the level of glutamate, the primary excitatory neurotransmitter which is responsible for the consolidation of memories, is increased and namely that can explain some memory problems among patients with PTSD. Finally considering corticotropin (CRH) and norepinephrine (NE) the increased levels of both chemicals is noticeable which explain exaggerated stress responses, numbing, analgesia, disassociation, and so on.

\section{Conclusion.}

In conclusion, we would like to say that PTSD is a very severe problem in our modern word, and the changes which occur after the traumatic event can lead to a very significant changes on the level of the brain and neurochemistry. That is why it is very important to understand those changes and take them into account when scientists develop new medications which are aimed to decrease the severity of the symptoms.

\section{References:}

1. Sakellariou M. O. \& Stefanatou A. (2017). Neurobiology of PTSD and implications for treatment: An overview. Curr Res Integr Med, 2(1), 50-53. Retrieved from https://www.pulsus.com/scholarlyarticles/neurobiology-of-ptsd-and-implications-for-treatment-an-overview.html.

2. Stanford University. (2019). Biology may make certain PTSD patients unresponsive to behavioral therapy. Retrieved from https://neurosciencenews.com/unresponsive-ptsd-biology-10994/.

3. Kelmendi, B., Adams, T. G., Yarnell, S., Southwick, S., Abdallah, C. G., \& Krystal, J. H. (2016). PTSD: from neurobiology to pharmacological treatments. European journal of 
psychotraumatology, $\quad 7, \quad 31858$ doi:10.3402/ejpt.v7.31858. Retrieved from https://www.ncbi.nlm.nih.gov/pmc/articles/PMC5106865/.

4. Lanius, R., \& Olff, M. (2017). The neurobiology of PTSD. European journal of psychotraumatology, 8(1), 1314165. doi:10.1080/20008198.2017.1314165. Retrieved from https://www.ncbi.nlm.nih.gov/pmc/articles/PMC5475317/.

5. Barlow, D. H. \& Durand, V. M. (2015). Abnormal Psychology: an Integrative Approach (7th ed). USA: Cengage Language.

6. Kring, A. M. \& Johnson, S. L. Abnormal Psychology (13th ed.).

7. Davison, G. C. \& Neale, J. M. (2017). USA: Wiley Custom.

8. Howard, S. \& Crandall, M. (2007). Post-traumatic stress disorder. What happens in the brain? Washington Academy of Science, 93(4). 1-17.

9. Sherin, J. E. \& Nemeroff, C. B. (2011). Post-traumatic stress disorder: The neurobiological impact of psychological trauma. Dialogues in Clinical Neuroscience, 13(3), 263-278.

10. Bowirrat, A., Chen, T. H. \& Blum, K., et al. (2010). Neuro-psychopharmacogenetics and neurological antecedents of posttraumatic stress disorder: Unlocking the mysteries of resilience and vulnerability. Current Neuropharmacology, 8(4), 335-358.

11. O'Doherty, D. M., Chitty, K. M. \& Saddiqui, S., et al. (2015). A systematic review and meta-analysis of magnetic resonance imaging measurement of structural volumes in post-traumatic stress disorder. Psychiatry Research: Neuroimaging, 232(1), 1-33.

12. Sartory, G., Cwik, J. \&Knuppertz, H. (2013). In search of the trauma memory: A meta-analysis of functional neuroimaging studies of symptom provocation in post-traumatic stress disorder (PTSD). PLOS ONE, 8(3).

13. Stark, E. A., Parsons, C. E. \& Van Hartevelt, T. J., et al. (2015). Post-traumatic stress influences the brain even in the absence of symptoms: A systematic, quantitative meta-analysis of neuroimaging studies. Neuroscience and Bio-behavioral Reviews, (56), 207-221.

\title{
DOI 10.36074/25.10.2019.v2.14
}

\section{TENDENCIES OF EDUCATION DEVELOPMENT IN UKRAINE}

\author{
Svetlana Yashnyk \\ D.Sc. (Pedagogy), Professor of the Department of Psychology \\ National University of Life and Environmental Sciences of Ukraine
}

UKRAINE

Ukraine, as a European country, chooses European standards of life and human development. The pragmatics of time requires careful study of all components of the modern educational space because reforming Ukrainian education is not so much a political and economic problem, but the question of preserving society and national culture based on dialogue, which is of particular importance today. Therefore, the innovative goal of 21 st-century education is to ensure the sustainable development of civilization. We need organizational and pedagogical changes, a new dimension, scale, that is, a new function of education through the expansion and updating of existing ones. Thus, a new global goal, the image of the desired model of sustainable development of innovative education in change through an 
expansion of its functions, is crystallized - the educational provision for the sustainable development of civilization. The stated Objective is in line with the Agenda for Action of the 21st Century, where the emphasis is on "reorienting education to sustainable development." Issues of the problem of educational development are the subject of research of such national scientists as V. Andrushchenko, M. Yevtukh, V. Kremen, S.Nikolaenko, and others.

In practice, the provisions of the educational paradigm are embodied in practical approaches to education, which determine the directions of innovative educational projects, namely: An anthropocentric approach that aims to form an independent creative personality. The highest value is the holistic person, not the social machine cog. The content of education is the development of creativity and the production of self-presentation. Within this approach, there are different interpretations and accents: (1) romantic - focuses on the education of creative foundations; (2) pragmatic - focuses on personal growth; (3) personal - emphasizes the forms of development of human psychophysical qualities and the need to achieve harmony with the world. This approach to education is most widely represented - it has many manifestations in educational practice (Waldorf schools, Montessori schools) [9].

Theocentric approach, which emphasizes the purpose of education to attain unity with the primordial world, to approach the Higher, final instance, which carries the objective truth of justice, goodness, common culture and freedom. The highest value in the context of this approach is enlightenment and grace. The content is to study and understand the sacred texts, on the one hand, and on the other, the technique of communicating with the Higher Mind or achieving enlightenment. This approach is more common in the East, especially in the Taoist and Buddhist traditions [7].

The traditionalist approach focuses on the reproduction of traditions, accepted attitudes, and life forms in a particular society or ethnic group. The purpose is to introduce into the tradition and create the continuers and keepers of the traditions of previous generations, the tradition is of the highest value. The content of education under this approach includes the development of languages, rituals, crafts, and mythology of a particular ethnic group. This approach, which was widespread in the traditional societies of Europe in the Middle Ages, is now practiced in public schools and educational institutions targeting ethnic groups [6].

The social approach focused on the training and education of citizens of the state, from which the purpose - to provide the state machine functionaries, and the labor market - skilled workers, and the highest value - the development of the state and social career. The content of education is an explanation of social functions and patterns of their distribution, learning how to work in a functional place. This approach is dominant because it is actually supported by the state and the labor market [5].

The mental-activity approach, which aims at reproducing and developing the ability of society to preserve and create forms of thought and activity, involves the inclusion of man through education in the world of thinking and activity. This approach argues that it is not the individual that generates thinking and activity, but the collective thinking and activity that engenders man. The highest values are the creation of new forms of thinking and activity, the preservation and reproduction of the world of mental activity. Content is the development and practice of essential intellectual functions - thinking, understanding, expression, reflection in the forms of 
mental activity, mental communication, and clear thinking through the assimilation and deployment of the method [8].

According to O.O. Savchenko, in the world of educational practice, the selection of reproductive-conservative and progressive-humanitarian educational paradigms as basic ones has become entrenched. According to the first of them, a holistic scientific picture of the world and man, which relies on the comprehension of the results of all sciences, must be at the heart of education. According to the second, the image of the world and man is the product of the creative activity of the human communities inherent in their cultural and historical foundations. The reproductiveconservative paradigm of education, which is the consequence of penetration into the educational process of scientific rationality, in some way ignores the desire of the individual to independently and independently search for the meaning of phenomena and things of human existence itself. In the context of such a paradigm, life is considered utilitarian enough: live to learn, study to master the profession, work to have the means to live. Proponents of the progressive humanistic focus on education place the personality with its characteristics, strengths, and weaknesses, with its needs. For a person, they believe, the moment becomes the correspondence of his personal qualities to his activity. Development and selfdevelopment, self-realization, life-giving are all at the heart of the humanistic model of education, the purpose of which is to ascend the individual to a higher level of activity and independence. They understand personality activity as emotional force, tempo rhythm of action, self-orientation and self-actualization, power of reason, as well as the presence of needs, experiences, creative activity, motives, conscious aspirations, and social roles [2].

Thus, the progressive-humanistic paradigm of education implies the transition from utilitarian-pragmatic goals of education as a set of knowledge, skills, and skills for successful implementation of industrial activity, to a humanistic goal - to the subject, to his personal development. Thus, the purpose of education, the realization of which involves not only the assimilation of the socio-cultural experience of humanity but also the process of self-formation of the individual, its self-realization through the production of experience (knowledge) having a dual nature - individual-personal and socio-cultural experience of humanity.

The philosophy of humanism in a new way assesses social problems, gives the personal meaning of the content of the whole educational process, helps education in determining the person, and his role in the system of world culture. The primary way of structuring knowledge is a cultural approach to education, based on the integration of disciplines, creating a holistic reflection of the era, culture, understanding the relationship between culture and civilization, understanding each area of knowledge in the formation of culture.

So, in the modern world, the content of education and approaches to the educational process are changing. Education ceases to be interpreted as achieving a certain level of knowledge and is viewed from the standpoint of "continuity in life," which aims to develop the individual, the formation of his spirituality and culture, planetary thinking [1, 2, 3, 4]. Instead of the traditional-classical approach - routine assimilation of large volumes of standardized information, modern education uses a competent approach - based on mastering the means of continuous selfacquisition of new knowledge, which develops the ability and ability to adapt to complex, fast-paced and unforeseen situations. The competency approach 
determines the result-oriented orientation of education, which, in our opinion, is its indisputable advantage over traditional approaches.

\section{Список використаних джерел:}

1. Євтух, М. Б. \& Яшник, С. В. (2017). Інноваційна діяльність в освіті: становлення гуманістичної парадигми. Науковий вісник Національного університету біоресурсів $i$ природокористування України. Серія «Педагогіка, психологія, фрілософія», 86-94.

2. Савченко, О. О. (2008). Західна парадигма освіти на початку XXI століття (соиіальнофілософрський аналіз). Харків.

3. Яшник С. В. (2011). Аксіологічне переосмислення сучасного освітнього простору. Науковий вісник Національного університету біоресурсів та природокористування України, (159), Ч. 4, 266-272.

4. Яшник, С. В. (2014). Компетентістний підхід до розробки галузевих стандартів вищої освіти у підготовці фахівців лісогосподарської галузі. Проблемы современного педагогического образования. Серія: Педагогика и психология, (45). Ч. 5, 332-342.

5. Archer, L. (2003). Higher Education and Social Class: Issues of Inclusion and Exclusion. RoutledgeFalmer.

6. Bresnick, D. (1978). Black/white/green/red: The politics of education in ethnic America (Educational policy, planning, and theory). Longman.

7. Burgess, H. W. (2007). Models of Religious Education: Theory and Practice in Historical and Contemporary Perspective. Evangel Publishing House.

8. Luqueer, F. L. (2007). Hegel as educator (1896). Kessinger Publishing, LLC.

9. Spindler, G. D. (1997). Education and cultural process: anthropological approaches. Waveland Press.

\section{ПСИХОЛОГІЧНИЙ СУПРОВІД ТВОРЧО-ОБДАРОВАНИХ ПІДЛІТКІВ В УМОВАХ РЕКРЕАЦІЙНОГО ЗАКЛАДУ}

Грек Олена Миколаївна

канд. психол. наук, доцент, доцент кафедри психології розвитку та соціальних комунікацій ДЗ «Південноукраїнський національний педагогічний університет імені К.Д.Ушинського»

УКРAÏHA

В сучасних умовах розвитку суспільства значна роль відводиться підтримці та розвитку внутрішнього потенціалу особистості школярів, та особливої актуальності набуває проблема розвитку дитячої обдарованості. До проблеми дитячої обдарованості зверталися такі науковці, як Д.Б. Богоявленська, Л.А. Венгер, Дж. Гілфорд, В.М. Дружинін, О.Л. Кульчицька, Н.С. Лейтес, В.О. Моляко, Я.О. Пономарьов, П. Торренс та ін. В роботах вчених розкриті сутність, структура та види творчої обдарованості, а також особливості ії розвитку у дітей та підлітків. Так, Н.С. Лейтес обдарованість розглядає як своєрідне поєднання здібностей, яке визначає діапазон видів діяльності, в яких обдарована людина може досягти великих результатів, ніж інші. В.О. Моляко вважає однією 3 основних якостей творчої особистості $€$ прагнення до 
оригінальності, до нового, заперечення звичного, а також високий рівень знань, умінь аналізувати явища, порівнювати їх, стійкий інтерес до певної роботи, порівняно швидке і легке засвоєння теоретичних і практичних знань у цій галузі, систематичність і самостійність у роботі [1]. Серед характеристик творчо-обдарованих підлітків науковці виділяють високий рівень розвитку будь-яких здібностей в одній або декількох сферах, таких як академічна, інтелектуальна, соціальна, творча, художня та ін., розвинене творче мислення та його структурні компоненти (продуктивність, оригінальність, гнучкість), достатньо високий рівень розвитку креативності, вміння створювати нові творчі продукти, досить високий темп навчання, допитливість, уява та прагнення до рішення проблем, почуття гумору, а також можливості виходити за межі досягнутого рівня розвитку (за Д.Б.Богоявленською, Н.С.Лейтес, B.О. Моляко). Серед критеріїв, які виокремлюють творчо-обдарованого підлітка серед ровесників $є$ наявність у нього специфічних стратегій діяльності, сформованість якісно своєрідного індивідуального стилю діяльності, особливий тип навченості, яскраво виражений інтерес до тих чи інших сфер діяльності, надзвичайно висока захопленість предметом, висока критичність до результатів власної праці, прагнення до досконалості [2]. Проте, як зазначають вчені, якщо творчо-обдарований підліток не знаходить свого міста у суспільстві та не може адаптуватися, то його потенціал може стати проблемою [3]. На нашу думку, особливо це стосується творчо-обдарованих підлітків, які відпочивають у рекреаційних закладах.

В сучасній науці робляться спроби розробки та впровадження програм психологічного та соціально-педагогічного супроводу творчо-обдарованих школярів в умовах навчальних закладах. Проте, наші дослідження свідчать про необхідність розробки програм психологічного супроводу творчообдарованих школярів, зокрема підлітків, в умовах рекреаційного закладу. Як зазначає О.І. Гуренко, соціально-педагогічний супровід творчо-обдарованих підлітків має здійснюватися такими суб'єктами, як батьки, соціальні педагоги, психологи, вчителі шкіл та позашкільних навчальних закладів та цей супровід відбувається в три етапи (підготовчий, безпосередня діяльність, підсумковий) [4]. Спираючись на особливості відпочинку школярів у рекреаційних закладах (21 день) нами було розроблено програму психологічного супроводу творчообдарованих підлітків в умовах рекреації (на прикладі дитячого центру «Молода гвардія»). Програма психологічного супроводу творчо-обдарованих підлітків в умовах рекреації включає такі етапи: 1. Діагностичний етап діагностика творчо-обдарованих підлітків за визначеними методиками; 2. Індивідуально-консультаційний етап - надання психологічної допомоги творчо-обдарованим підліткам в адаптації до умов закладу; 3. Корекційнорозвивальний етап - проведення психологічного тренінгу з розвитку творчообдарованих підлітків; 4. Заключний етап - діагностика та визначення змін наприкінці зміни у творчо-обдарованих підлітків. Напрямками роботи психологічного тренінгу 3 творчо-обдарованими підлітками $\epsilon$ : створення сприятливої психологічної атмосфери в колективі, розвиток креативності та творчого мислення, спостережливості, пізнавального інтересу; розвиток товариськості; розвиток адекватної самооцінки; розвиток навичків спілкування та міжособистісної взаємодії. 
Проведено апробацію розробленої програми психологічного супроводу творчо-обдарованих підлітків в умовах рекреаційного закладу. В дослідженні приймали участь 100 творчо-обдарованих підлітків, які відпочивали у ДП УДЦ «Молода гвардія». Повторна діагностика розвитку структурних компонентів творчості та індивідуальних характеристик у досліджуваних після проведення програми супроводу дозволила виявити статистично значущі різниці між оцінками в роботах творчо-обдарованих підлітків експериментальної групи за показниками візуальної продуктивності, оригінальності, гнучкості, товариськості та самооцінки (на рівні $р<0,05$ ). Отже, доведена ефективність використання розробленої програми психологічного супроводу творчообдарованих підлітків в умовах рекреаційного закладу.

\section{Список використаних джерел:}

1. Богоявленская, Д. Б. \& Богоявленская, М. Е. (2005). Психология одаренности: понятия, виды, проблемы, (Вып. 1). Москва: МИОО.

2. Гуренко, О. И. (2014). Социально-педагогическое сопровождение творчески одаренных подростков в общеобразовательной школе. Поддержка одаренности - развитие креативности: материалы международного конгресса, (1), 59-64. Вилучено із https://elibrary.ru/download/elibrary_21963924_99156472.pdf.

3. Моляко, В. О., Біла, I М. \& Ваганова, Н. А. (2012). Психологічне дослідження творчих периептивних процесів на різних вікових рівнях. В. О. Моляко (ред.). Кіровоград: Імекс-ЛТД.

4. Ушаков, Д. В. (ред.) (2000). Психология одаренности: от теории к практике. Москва: ИП $\mathrm{PAH}$.

DOI 10.36074/25.10.2019.v2.15

\section{ПСИХОЛОГИЧЕСКИЕ ОСОБЕННОСТИ ФОРМИРОВАНИЯ СОЦИАЛЬНО АДАПТИРОВАННОЙ АКТИВНОЙ ГАРМОНИЧНО РАЗВИТОЙ ЛИЧНОСТИ НА ПРИМЕРЕ СТАРШЕКЛАССНИКОВ}

Кернас Андрей Вячеславович

канд. психол. наук, с.н.с., руководитель отдела Естественных наук и психологической гармонизации развития личности, Научно-технический

центр Академии связи Украины

Максимихина Оксана Валентиновна педагог отдела Естественных наук и психологической гармонизации развития личности, Научно-технический центр Академии связи Украины

УКРАИНА

В настоящее время проблема фрормирования социально адаптированной активной гармонично развитой личности продолжает оставаться одной из наиболее важных проблем современной психологии и педагогики.

15 (или 14-16) лет - переходный период между подростковым и юношеским возрастом. Это время приходится на 9-й класс, если иметь в виду 11-летнюю 
общеобразовательную школу. В 9-м классе решается вопрос о дальнейшей жизни: что делать - продолжить обучение в школе, пойти в училище или работать? По существу, от старшего подростка общество требует профессионального самоопределения, хотя и первоначального. При этом он должен разобраться в собственных способностях и склонностях, иметь представление о будущей профессии и о конкретных способах достижения профессионального мастерства в избранной области. Это сама по себе сложная задача. Еще более она усложняется в наше время - переломный исторический период, когда рушатся выработанные предыдущими поколениями стереотипы, ценности, в частности, представление о значимости образования и престижности той или иной профессии [3].

В то же время, как отмечает Ю.Б.Гиппенрейтер, опыт, который имеет непосредственное отношение к личности, - это система представлений о нормах и ценностях жизни человека, о его общей направленности, поведении, отношениях к другим людям, к себе и обществу в целом и т.п. Они зафиксированы в очень различных формах - в философрских и этических воззрениях, в произведениях литературы и искусства, в сводах законов, в системах общественных наград, поощрений и наказаний, в традициях, общественных мнениях... вплоть до родительских указаний ребенку на то, «что такое хорошо», и то «что такое плохо» [1].

Понятно, что в различных культурах, в разные исторические времена эти системы норм, требований, ценностей были различны и порой отличались очень сильно. Однако смысл их от этого не меняется. Он может быть выражен с помощью таких понятий, как «объективное предбытие» или «социальные планы» (программы) личности [1].

Общество организует специальную активность, направленную на реализацию этих «планов». Но в лице каждого индивида оно встречает отнюдь не пассивное существо. Активность общества встречается с активностью субъекта. Процессы, которые при этом разыгрываются, и составляют самые главные, порой драматические, события в ходе формирования и жизни личности [1].

В свою очередь В.П.Кутишенко обращает внимание на то, что главным в становлении личности старшеклассника является открытие собственного внутреннего мира, которое проявляется в форме переживания своей индивидуальной целостности и неповторимости. Внутренний мир приобретает для него особую ценность. Осуществляется интенсивное развитие самосознания. Вместе с осознанием своей уникальности приходит ощущение одиночества. Отсюда растет потребность в общении, потребность сопоставления себя с образом типичного ровесника. Осознание своей уникальности предшествует пониманию глубокой связи с другими людьми [4].

Далее В.П.Кутишенко обращает внимание на то, что у старшеклассника появляются важные личностные качества: осознанность, самостоятельность, независимость. Он ставит перед собой и активно решает сложные жизненные проблемы. Рефлексия собственного жизненного пути, стремление к самореализации приводит к появлению новых социальных потребностей: занять свое место среди других, выделяться, быть особенным, играть определенную роль в обществе. Возникает ответственность не просто за 
себя, а за себя в общем коллективном деле, за общее дело и за других людей. Итак, новообразованием этого возраста является самоопределение себя в человеческом обществе, осознание своих возможностей и стремлений, своего назначения в жизни [4].

Таким образом, на основании проведенного теоретического анализа научной и научно-методической литературы, мы сделали выводы о целесообразности составления комплексной методики психологопедагогических приемов, по своему целевому назначению направленных на преодоление сложностей, связанных с социальной адаптацией старшеклассников, выработкой их активной жизненной позиции, установкой на самореализацию и успех, формирование идеального «Я» личности старшеклассника.

Исследование проводилось в течение 2 календарных месяцев на базе Отдела естественных наук и психологической гармонизации личности Научнотехнического центра Академии связи Украины.

В исследовании приняли участие 25 старшеклассников в возрасте от 14 до 16 лет, из которых 14 девушек и 11 юношей.

При составлении плана практической работы и отбора набора психологопедагогических приемов мы руководствовались целесообразностью эффективности и относительной простотой (с учетом возрастных особенностей старшеклассников).

Как известно, содержание взаимодействий служит средством для понимания процессов взаимодействия. Изучение групповых процессов и групповой динамики дает информацию о межличностных отношениях и поведении членов группы в реальной жизни. Развитие межличностных умений и социально-психологической компетентности предполагает понимание групповых процессов, поощряющих самовосприятие [2].

Согласно Т.Зайцевой, большинство эффективных изменений происходит в групповом, а не индивидуальном контексте. Для того, чтобы выявить и изменить свои не адаптивные установки и выработать новые формы поведения, люди должны учиться видеть себя такими, какими их видят другие [2].

Соглашаясь с мнением автора в том, что работа в группе не является весьма эфффективной и позволяет выявить явные недостатки личности, в то же время для нас представлялась очевидной целесообразность проведения также и индивидуальной работы, направленной на исправление негативных качеств личности, препятствующих социальной адаптации личности и ее гармоническому развитию.

Таким образом, в ходе проведения формирующего эксперимента нами осуществлялась параллельно практическая работа по двум направлениям: групповые занятия и индивидуальные занятия.

Краткое описание разработанной нами комплексной методики приводится ниже.

1. Инструктаж. Целью было рассказать участникам эксперимента о важности строгого безукоснительного выполнения всех заданий.

2. Анкетирование с целью выяснения самовосприятия и самоидентичности старшеклассников. На этом же этапе проводились беседы. 
3. Проведение групповых занятий гетеротренинга. Цель - средствами рационального внушения сформировать правильную самоидентификацию себя в социуме.

4. Проведение комплекса групповых игровых занятий, в ходе которых перед участниками ставились следующие задания:

1) Участники эксперимента разбивались на небольшие группы по 3-4 человека, садились за стол и общались между собой. Каждый рассказывал о себе, о ближайших планах на будущее, своих увлечениях, о том, как юноша или девушка самоидентифицирует себя внутри школьного коллектива, в кружке по интересам или спортивной секции, которую он или она посещает. Во время проведения беседы остальные участники эксперимента оставались пассивными наблюдателями. После завершения беседы необходимо было высказать свое мнение о конкретном человеке, реальности его планов и соответствии его восприятия себя реальному взгляду со стороны. Высказывались как активные участники, так и пассивные наблюдатели;

2) Ставилось задание изобразить ситуацию: человек пришел устраиваться на работу и проходит собеседование с работодателем;

3) Человек проходит собеседование при поступлении в учебное заведение.

5. Занятие физической культурой и спортом.

6. Курс безопасности жизнедеятельности.

7. Проведение индивидуальных психологических и педагогических консультаций.

8. Повторное проведение анкетирования и бесед с целью получения данных и их сопоставления с первоначальными.

По итогам проведенного исследования можно сделать выводы о положительном влиянии предлагаемой нами методики психологопедагогических приемов, направленных на социальную адаптацию и гармоническое развитие личности старшеклассников.

\section{Список использованных источников:}

1. Гиппенрейтер, Ю.Б. (2002). Введение в общую психологию. М.: «ЧеРо», при участии издательства «Юрайт».

2. Зайцева, Т. В. (2002). Теория психологического тренинга. Психологический тренинг как инструментальное действие. СПб.: Речь; М.: Смысл.

3. Кулагина, И. Ю. \& Колюцкий, В.Н.(2004). Возрастная психология: Полный жизненный цикл развития человека. М.: ТЦ Сфера.

4. Кутішенко, В.П.(2010). Вікова та педагогічна психологія (2-ге вид.). Київ: Центр учбової літератури. 


\section{ТЕОРЕТИКО-МЕТОДОЛОГІЧНИЙ АНАЛІЗ МЕТОДІВ АКТИВІЗАЦІЇ МИСЛЕННЯ СТУДЕНТІВ В ПРОЦЕСІ НАВЧАЛЬНОЇ ДІЯЛЬНОСТІ У ЗВО}

Бужинська Світлана Миколаївна

канд. псих. наук, доцент, доцент кафедри педагогіки, психології, початкової освіти та освітнього менеджменту Комунальний заклад «Харківська гуманітарно-педагогічна академія» Харківської обласної ради

Соколова Валерія студентка 2 курсу Комунального закладу «Харківська гуманітарно-педагогічна академія» Харківської обласної ради УКРАЇ̈A

Проблема активізації мислення студентів на сьогоднішній день набуває все більшої актуальності. I це закономірно, оскільки навчання - провідний вид діяльності студентів, в процесі якого вирішуються головні завдання, поставлені перед вищим навчальним закладом: підготувати студентів до вирішення пізнавальних задач, до активної участі в науково-технічному, соціальному процесі тощо.

Метою роботи $є$ теоретичне дослідження активізації мислення як чинника ефективності навчальної діяльності студентів.

Активізація мислення студентів під час навчальної та пізнавальної діяльності полягає у застосуванні такого змісту, форм, методів, прийомів і засобів навчання та психологічних методик, які сприятимуть підвищенню їх пізнавального інтересу, активності, творчості, а отже, і в самостійності одержанні знань, формуванні вмінь та навичок та використання їх на практиці. Активізація мислення, це дія яка веде за собою активізацію і розумової діяльності, внаслідок чого відбувається прискорення процесу мислення [5].

Щодо досліджень у даній області, то в даний час науковцями проведені фрундаментальні дослідження когнітивних стилів, в рамках яких розглядалися стильові особливості мислення (А. В. Либин, 1996; В.А.Колга, 1976; Г. А. Уіткін, 1974; Дж. А. Келлі, 1955; Дж. Каган, 1966; Дж. С. Клейн, 1959; І. П. Шкуратовой, 1994; М. А. Холодної, 2004; П. Хольцмана, 1959; Р. В. Гарднер, 1959 та ін.). Були вивчені когнітивні стилі, що розкривають різні характеристики мислення: швидкість прийняття рішень - імпульсивність / рефрлексивність (Дж. Каган, 1966), широта-вузькість використовуваних понять - вузька / широка категоризація (Д. Блок, 1981), рівень розвитку понять конкретна / абстрактна концептуалізація (Д. Хант, О. Харві, Х. Шродер, 1961).

Різноманітні засоби активізації мислення студентів було також обґрунтовано в працях багатьох українських педагогів, зокрема Б. Грінченка, В. Помогайби, О. Білецького, О. Музиченка, О. Потебні, С. Русової та ін.

Студентство це особлива соціальна категорія, специфічна спільнота людей, організовано об'єднаних інститутом вищої освіти. Студенти відрізняються від інших груп населення високим освітнім рівнем, високою 
пізнавальною мотивацією, найвищою соціальною активністю і досить гармонійним поєднанням інтелектуальної і соціальної зрілості [1].

Розвиток особистості студента під час навчання у ЗВО на різних курсах має свою специфіку. Діяльність студента у ЗВО специфічна за своєю метою, умовами, мотивами в порівнянні з навчанням в школі. Разом з тим вона $€$ основним шляхом формування особистості майбутнього спеціаліста з вищою освітою [1].

Ядром навчально-пізнавальної активності студентів $є$ розумова діяльність та мислення, які розглядаються як цілісна система розвитку особистості і сполучна ланка між процесом пізнання об'єктивної реальності і розвитком особистості студента.

Існують вікові відмінності в динаміці розвитку стилів мислення. Науковцями виділено сенситивні (досягають піку в розвитку) і критичні (мінімальні значення) періоди в розвитку кожного стилю мислення студентів $[4,5]$.

Мислення студентів характеризується тим, що воно є цілеспрямованим і продуктивним процесом. Цілеспрямованість його виявляється в розв'язанні нових задач, у розкритті безпосередньо не даних і істотно важливих для людини зв'язків і відношень речей. Втрачаючи свою пізнавальну цілеспрямованість, мислення стає непродуктивним. Продуктивність же його характеризується створенням відповідних дійсності розумових образів, знань, які глибше й повніше відображають цю дійсність, ніж чуттєве її пізнання, як наслідок - дають відповіді на питання, які постають перед людиною в її житті [4].

Активізація пізнавальної діяльності студентів тісно пов'язана з активізацією їх мислення. У психологічному значенні поняття активність $€$ сутнісною ознакою діяльності, в якій суб'єкт змінює свою поведінку і свої психічні властивості. Активізація навчально-пізнавальної діяльності - це підвищення рівня усвідомленого пізнання об'єктивно-реальних закономірностей у процесі навчання [4].

Активізація $€$ постійно протікаючим процесом спонукання студентів до енергійного, цілеспрямованого учіння і мислення, подолання пасивної і стереотипної діяльності, спаду і застою в розумовій роботі. Головна мета мисленнєвої активізації - формування мисленнєвої активності студентів, підвищення якості навчально-пізнавальної діяльності [5].

У студентів потрібно сформувати також мотиви навчання, головним з яких $\epsilon$ інтерес до якогось предмету чи явища, з метою активізувати їх мислення [4].

Також, необхідною умовою повноцінного засвоєння знань $€$ опора на активну розумову діяльність студентів, яка спрямована на переробку засвоюваного матеріалу. 3 цією метою в психології та педагогіці розроблено ряд прийомів активізації розумової діяльності студентів у процесі засвоєння ними знань [4].

Методи активізації продуктивної мисленнєвої діяльності - це спеціальні практичні психолого-педагогічні прийоми, спрямовані на підвищення ефективності протікання розумового процесу, та його продуктивності. Розробка методів обумовлена тими чи іншими теоретичними підходами до розуміння продуктивної природи мислення, його механізмів [2]. Зупинимось докладніше на характеристиці цих методів.

Методи психологічної активізації продуктивної розумової діяльності спрямовані на усунення інерції мислення, яка може перешкоджати всебічному глибокому розгляду проблеми. Ці методи дозволяють значно збільшити число 
висунутих ідей і підвищують продуктивність розумової діяльності. Найбільш відомим 3 них $\epsilon$ метод «мозкового штурму» («мозкової атаки»), запропонований А. Осборном (США) [2].

Прийоми використання аналогій та стимулювання творчого мислення також відносяться до методів психологічної активізації продуктивної розумової діяльності. Найбільш цікавим методом, що використовує аналогії, $\epsilon$ «синектика» - метод вирішення проблем в групі при широкому використанні різних типів аналогій. Цей метод був запропонований У. Гордоном (США) [2].

3 «синектикою» перегукується метод подолання інерційного ефекту мислення (Дж. Мендел). Головна мета якого полягає у руйнуванні стереотипів розумового процесу, формуванні здатності побачити нове у вже відомому. На відміну від "синектики» цей метод призначений для індивідуального застосування і містить рекомендації щодо організації творчого процесу на тривалий термін, а не тільки на обмеженому відрізку часу [2].

Область використання аналогій досить широка. Зокрема, прийоми аналогії можуть бути використані для [2]: виявлення тенденцій розвитку різних об'єктів і галузей науки і техніки; прогнозування розвитку суспільних і особистих потреб і засобів для їх задоволення; перевірки і демонстрації на моделі задуму рішення задачі; тренування пам'яті та розвитку уяви; активізації мислення тощо. Описані методи психологічної активізації мислення доцільно використовувати спільно з іншими методами стимулювання розумової діяльності.

Таким чином, узагальнюючи вищесказане, можемо дійти до висновку, що застосування викладачем у процесі навчання студентів методів активізації мислення сприяють реалізації таких принципів сучасних концепцій викладання, як [3]: проблемності: вихідним пунктом процесу навчання повинна бути постановка проблеми з реального життя, яка пов'язана з інтересами й потребами тих, хто навчається; погодженості та системності цілей навчання: навчання, що має за мету зміну поведінки та охоплює всі аспекти ділової компетентності; орієнтованості на наявний досвід: ефрективне навчання можливе лише за опори на наявний досвід, що вимагає гнучкості концепції навчання та дає змогу враховувати досвід студентів; націленості на самонавчання: за результати навчання у першу чергу відповідальність несуть студенти, а викладач лише допомагає; професійної орієнтованості: орієнтація на практичне використання отриманих умінь $€$ ключовим елементом концепції навчання; зворотного зв'язку: студенти постійно отримують оцінку успішності своїх дій.

\section{Список використаних джерел:}

1. Алексюк, А. М. (1998). Педагогіка вищої освіти України (с. 520-521). Київ: Либідь.

2. Булавенко, С. Д. (2012). Методи активізації мислення. Психологія в школах України, 1(86), 20-24.

3. Пономарьова, Г. Ф. \& Степанець, І. О. (2010). Активізація навчально-пізнавальної діяльності студентів ВНЗ на заняттяя із педагогіки. Харків: ФОП Шейніна О. В.

4. Садова, Т. А. (2008). Активізація пізнавальної діяльності студентів як умова підвищення якості навчального процесу. Наука і освіта, (1-2), С. 27-30.

5. Щепіна, Н. В. Активізація навчально-пізнавальної діяльності студентів ВНЗ як наукова проблема. Вилучено 3 http://www.nbuv.gov.ua. 


\title{
ХУДОЖНЯ ЛІТЕРАТУРА ЯК ЗАСІБ ОПТИМІЗАЦІЇ АДАПТАЦІї ВІЙСЬКОВОСЛУЖБОВЦІВ ДО МИРНИХ УМОВ
}

\author{
Казьмірук Анна Василівна \\ студентка факультету психології, \\ Національний педагогічний університет імені М.П. Драгоманова \\ Науковий керівник: Ставицька С.О. \\ доктор психологічних наук, професор, завідувачка кафедрою загальної \\ і соціальної психології та психотерапії \\ Національний педагогічний університет імені М.П. Драгоманова \\ УКPAЇHA
}

Під час в'єтнамської війни загинуло 58 тисяч американців, тоді як упродовж наступних десяти років після закінчення війни вчинили самогубство ще 60 тисяч ветеранів. Америка, усвідомивши глибину ситуації з запізненням, стала створювати центри реабілітації для військових та членів їхніх родин. Війна в Афганістані закінчилась у 1989 році, але багато з тих, хто на ній побував, до цього часу відчуває себе чужинцем у суспільстві. За попередніми підрахунками громадських активістів, реабілітація після закінчення АТО буде потрібна «близько шістьом мільйонам українців. Близько 100 тисяч з них - учасники бойових дій, близько 500 тисяч - члени їхніх сімей, більше півмільйона вимушені переселенці і близько п'яти мільйонів чоловік - ті, хто проживає в зоні конфллікту чи на прифрронтових територіях» [1].

Проблеми особливостей переживання людиною психотравмуючих ситуацій, пошуку ресурсів для повноцінної життєвої адаптації вивчали багато психологів. Зокрема, К.А. Абульханова-Славська, А.Бондаренко, В.Н. Дружинін, А.Г. Караяні та І.В. Сиромятніков, М.І. Козлов, Л.А. Пергаменщик, М. Лаад та Е. Хадомі, А.А. Налчаджян, С.Л. Соловйова та ін.

Актуальність дослідження зумовлена тим, що у зв'язку з подіями на сході України більшість військовослужбовців, повертаючись додому, важко адаптуються до мирних умов, що призводить до збільшення відсотку соціальних проблем, а саме: алкоголізм, самогубство, домашнє насилля тощо. Оскільки напрацювання способів допомоги учасникам бойових дій в Україні потребує вдосконалення, то наше дослідження може оптимізувати цей процес.

3 метою виявити приклад конструктивної адаптації колишніх військових ми дослідили три романи («Час жити і час помирати» Е.М.Ремарк, «До зустрічі там, на горі» П. Леметр, «Американський снайпер» К.Кайл), де відображені історії життя солдатів у різних умовах.

Аналізуючи роман Е.М.Ремарка «Час жити і час помирати» [2] та образ його головного героя Ернста Гребера ми виявили, що способів конструктивної адаптації автор не подає. 3 огляду на це ми припустили, що П`єр Леметр як сучасний письменник, ознайомлений із тим фрактом, що людина після війни може повернутись до повноцінного життя, опише у своєму романі «До зустрічі там, нагорі» [3] конструктивну адаптацію військовослужбовців до умов мирного середовища. Проте, знаючи про здобутки нашого часу, він однаково зображує неможливість людини пристосуватися через ті чи інші причини (як-от неприйняття солдата соціумом або самим себе) на прикладі головних героїв твору (Альбера Майяра та Едуара Перикура). Але на відміну від Е.М.Ремарка, 
П. Леметр пише і про категорію людей, які, потрапивши у психотравматичні обставини, посттравматичного синдрому не мають (Анрі д’Онле-Прадель).

Адаптація кожного військовослужбовця до мирних умов проходить порізному та залежить від багатьох чинників. С. Епштейн виділяє чотири базові установки особистості, які можуть оптимізувати це явище: 1) про доброзичливість навколишнього світу; 2) про його справедливість; 3) довіру до людей навколо; 4) про власну значимість.

Навіть якщо людина має просто позитивні ілюзії стосовно даних характеристик власного «Я» і навколишнього світу, це допомагає їй пристосуватися до ситуації, що склалася. Таким чином Ернст Гребер, Альбер Майяр та Едуар Перикур не змогли адаптуватися до незвичних для них після війни умов, оскільки всі чотири установки порушувалися. У романі Е.М.Ремарка «Час жити і час помирати» Гребер отримав тимчасову відпустку з фронту, але бойові дії тривали, суспільство перебувало у постійній напрузі та бідності, тобто про доброзичливість оточення і мови не йшло. Аналогічні умови бачимо й у творі П.Леметра «До зустрічі там, нагорі»: будівлі розтрощені, знищені, люди хапаються за будь-яку можливість заробити хоч трохи на прожиття, навіть якщо це означає порушити закон - ніхто не думає про ветеранів, які відчувають себе соціально незахищеними і непотрібними, вони не мають значення. У таких ситуаціях зникає довіра до оточення. Звичайно, Гребер мав близькі стосунки з Елізабет та Польманом, але чого варті двоє людей, коли навколо стільки потенційних зрадників і боягузів? Альбер та Едуар трималися разом лише через почуття провини, обов язку та безвиході, один одному вони довіряли лише на побутовому рівні.

Абсолютно інші умови спостерігаємо в художній автобіографії «Американський снайпер» [4], де вперше під час нашого дослідження зустрічаємо приклад конструктивної адаптації військового до мирного середовища. Це твір-сповідь Кріса Кайла, «морського котика», який був учасником бойових дій на Близькому Сході.

Слід визнати, що значно вплинули на пристосування Кайла декілька факторів. По-перше, Кріс, на відміну від Ернста, Альбера та Едуара служив за контрактом. Практикуючий військовий психолог Тарас Мацевко [5] стверджує, що із більшістю контрактників усе нормально, не виникає проблем у контексті психологічної стійкості, оскільки вони давно служать та свідомо зробили свій вибір. 3 мобілізованими трохи важче, бо хоч вони і мають базові знання, які отримали під час служби в армії у мирні часи, та все ж цивільні.

По-друге, солдатам, які брали участь у Першій та Другій Світових війнах, доводилося повертатися у країни, які «плювали їм в лице» [4]. Кріс же перебував у повністю мирному середовищі, що було вдячним йому. Іноді люди підходили до нього просто щоб сказати: «Чорт забирай, то це ви врятували наші шкури» [4]. Це доводить, що ветеранам потрібно, «щоб до них ставилися як до людей, якими вони є насправді: як до рівних, як до героїв, як до людей, які й далі мають надзвичайну цінність для суспільства» [4].

Кріс Кайл визнає, що повернення додому однаково було шоком: одного дня - війна, наступного - мир [4]. Психологи підраховують: для того, щоб людина нормально відновилася після участі у війні, їй потрібно бодай три місяці сприятливих умов. Тобто банального відпочинку без сильних психологічних навантажень, щоб мати змогу адаптуватися до нових реалій [6]. Коли Кайл тільки повернувся додому, то був випаленим, цілковито пригніченим і емоційно 
спустошеним [4]. Йому потрібен час на те, щоб побути вдома наодинці із самим собою, пройти «декомпресію» [4], «зняти свій плащ супергероя» [4].

Навіть незважаючи на сприятливі для пристосування умови, сформовану життєстійкість та довоєнну підготовку, був період, коли Кріс почав зловживати алкоголем, впав у депресію, бо йому було шкода себе [12]. Вийти із цього стану допоміг нещасний випадок - аварія, що наче його розбудила. На відміну від персонажів романів Е.М.Ремарка, період алкоголізації проходив у Кріса в усвідомленні, а також був недовготривалим.

Часом Кріс перевіряв Таю: розповідав про різні речі, просто щоб побачити, чи дасть вона собі з ними раду; не поспішав і випробовував ґрунт. Для нього було важливим знати, що вона не змінить свого ставлення до нього [4]. Психотерапевт Галина Дичковська констатує, що солдати приходять із війни зміненими, а дружини за ними не встигають і часто впадають у претензійність та образи. I наводить цікавий приклад: «Коли в 30-х роках набула популярності система «Анонімних алкоголіків», вони зіштовхнулися з дивною ситуацією. Якщо раніше сім'ї, де чоловік пив, якось трималися, то після того, як чоловіки кидали пити, - почали масово розпадатися. Бо чоловік змінився! I тоді «АА» запустили паралельну програму для сімей алкоголіків. Щоб люди змінювалися паралельно. І сім'ї отримували шанс. Із сім'ями військових треба працювати так само» [6]. Із часом Кріс і Тая виробили деякі нові звички [4], що безумовно посприяло міцності їхнього шлюбу.

Консультант Корпусу Миру Френк Пьюселік ділиться важливим етапом свого процесу адаптації: «Я, наприклад, перестав ображатися.(...) Я навчився «читати» людей, розпізнавати відтінки їхніх настроїв, чути співрозмовника. А ще навчився по-справжньому довіряти. I вважаю це безцінним даром війни» [7]. До аналогічних висновків приходить і Кріс: «Мені спочатку довелося подолати ту свою ображеність. Я мав пережити різні добрі та погані речі, перш ніж досяг точки, від якої справді міг рухатися далі» [4]. Тобто Кайл відчуває у собі зміни, усвідомлює, що вже не той, яким був, коли вперше пішов на війну [4], але це спрямовує у позитивне русло, тоді як Ернст стверджує: «Тепер ми - старі, але без досвіду старості. Старі, цинічні, позбавлені віри, інколи сумні. Не часто, але сумні» [2].

Оскільки процес реінтеграції колишнього військового у суспільство складний та тривалий, важливу роль у ньому відіграє оточення. Якщо воно налаштоване доброзичливо (за С. Епштейном), то лише оптимізує адаптацію солдата. Завдяки спілкуванню із своєю сім єю Кріс усвідомив, що є не тільки «морським котиком», а ще й чоловіком і батьком [4]. Окрім сім'ї про нього турбувалися друзі в Сан-Дієго і в Техасі, із розумінням та повагою ставилися сусіди [4]. Його бойовий побратим Раян, після того, як осліп внаслідок рикошету кулі, став своєрідним прикладом для наслідування. Кріса приваблював його могутній дух. У бою Раян був воїном. Тепер він став іще більшим воїном у житті [4]. Кріс називає Раяна плакатним типажем людини, яка подолала інвалідність, і пригаду як одного вечора товариш сказав, що радий, що таке сталося з ним, а не з кимось іншим. Звичайно, спершу він злився, але тепер чує, що умиротворений і живе повноцінним життям. Раян відчуває, що може дати собі раду і бути щасливим, хай там що [4]. Крім того, він написав лист, що заохочує кожного робити хоч щось для інших [4].

Ще одним позитивним прикладом для наслідування, підняття бойового духу була мати загиблого «морського котика» Марка Лі, Деббі. Вона після 
смерті сина стала, по суті, прийомною матір'ю для решти взводу. Дуже хоробра жінка, вона присвятила себе допомозі іншим воїнам, які покидали поле бою. Деббі надихала і Кріса.

Реінтегровуватися в суспільство, а також усвідомлювати свою цілісність, можливість дбати про сім ю і в чомусь малому піклуватися про інших [4]. Кріс почав завдяки спілкуванню з Маркусом Латреллом, який отримав поранення під час бойових дій в Афрганістані, а реабілітувався на ранчо своєї матері. Він стверджував, що одужував там удвічі швидше, ніж у госпіталі, бо відкритий простір і можливість вільно пересуватися природним чином сприяли цьому процесу. Це стало одною з тих речей, що надихнуло Маркуса на створення своєї фундації, а для Кріса одним із провідних принципів у тому, як він намагався вносити свою малу лепту [4]. Ще один патріотично налаштований друг Кайл, який підтримує військовослужбовців, дозволив їм використовувати його Босоноге ранчо для проведення різних заходів орієнтованих на поранених солдат [4]. Під час служби у ветерана може сформуватися насторожене і, відповідно, трохи зверхнє ставлення до цивільних, так як «вони не знають, що таке війна, а я їх захищав», тому найефективнішим способом психологічної реабілітації є співпраця «рівних». У такому випадку ветерани, які вже повернулися й соціалізувалися, працюють із «новачками», що і продемонстровано у художній автобіографії «Американський снайпер». Кріс розповідає про те, як вони привозили невеличкі групки інвалідів війни, і там вони полювали, стріляли на стрільбищі або просто тусували - просто гарно проводили час [4]. Результат не заставив на себе чекати, як згадує Кайл: «Ми лише починали, але зразу ж досягли достатніх успіхів, щоби госпіталі стали радо з нами співпрацювати» [4]. Отже, Кріс Кайл конструктивно адаптувався до мирних умов.

В одному із своїх інтерв'ю Френк Пьюслік розповідає: «У культурах різних племен $€$ особливе розуміння сутності воїна. Воїн - це захист племені. I з того моменту, як воїн пішов на війну, він перестає бути звичайною людиною назавжди. На війні ти - монстр, ти переступив межу. Заради людей, але переступив. I повернутися назад за цю межу вже неможливо. Тому перед поверненням із війни додому, воїн повинен був пройти обряд очищення під наглядом шамана. Обряд болючий. Щоб внутрішній монстр вийшов, а воїн став «людиною мудрості», якого суспільство поважатиме за те, що він урятував інших, ризикуючи собою» [1]. Щоб успішно адаптуватися до мирних умов військовослужбовець, перш за все, повинен реабілітуватися. Підхід роботи з травмою полягає у тому, що спочатку цю травму потрібно усвідомити («витягнути» із підсвідомого у свідоме), а тоді пропрацювати, конструктивно пережити, тобто проаналізувати почуття, емоції, можливі виходи із ситуації та зробити висновки.

Процес адаптації може ускладнюватися різними кризами - періодами, які ведуть до психологічної перебудови, виникненню психологічних утворень. Результати переживання особистісної кризи людиною можуть як підвищити її життєстійкість, відобразитися позитивно на її осмисленні життєвої ситуації та поведінці, так і спричинити стагнацію і деградацію особистості. В.В. Козлов виділяе основні паттерни переживань кризових станів: відчуття несправедливості, відчуття відчаю, невпевненість у собі, почуття самотності, страх, зміна системи цінностей [8]. Оптимізувати вихід особистості із кризового стану може арт-терапія, зокрема, застосування літератури. 
Для процесу адаптації важлива наявність сформованої життєстійкості, основою якої $€$ сенс життя. А.Н. Фомінова стверджує, що сенс життя розширюється, наповнюється при залученні особистості у культурний простір, у якому вона може черпати життєві сили [9]. Тож література, образи ідеальних героїв, гумористичні твори, високохудожні фільми світового кінематографу безперечно відіграють велику роль у знаходженні людиною життєвої опори.

Ми пропонуємо використовувати художню автобіографрію Кріса Кайла «Американський снайпер» під час індивідуальної і групової роботи із колишніми солдатами як твір, що може слугувати зразком позитивного наслідування для колишніх військових з метою допомогти їм пристосуватися до позафронтового середовища.

Тож ми розробили власний алгоритм проведення інтерактивного заняття, в основі якого лежить удосконалення рефлексії та комунікативних навичок, і зазначаємо основні його тези.

Після вступу і мотиваційної частини проводимо діагностику емоційного стану учасників (наприклад, за допомогою проективної методики Джона і Дайан Лампен «Дерево». Дерево із чоловічками - це спектр усіх можливих емоційних станів. Учасникам пропонується вибрати того чоловічка, який найбільше відповідає його емоційному стану на початку заняття, пояснити свій вибір та розмалювати кольором, що, на його думку, найбільше підходить для цього настрою (такий елемент арт-терапії використовуємо для зниження тривоги та напруги)).

Далі робота із текстом, під час якої зачитуємо вибрані уривки із твору (варто ретельно підійти до вибору тексту, оскільки він повинен торкатися учасників заняття своєю проблематикою, бути для них емоційно насиченим). Після цього обговорення та моделювання подібних ситуацій. Напрацювання можливих варіантів розв'язання. В кінці заняття проводимо повторну діагностику емоційного стану, щоб порівняти результати на початку і наприкінці. Під час зворотного зв'язку підбиваємо підсумки, обговорюємо висновки, до яких прийшли учасники, найбільш вражаючих моментів (акцент робимо на позитивних аспектах зустрічі).

Для роботи з текстом ми пропонуємо наступні уривки.

І. Кріс розповідає про початок надмірного вживання алкоголю і про те, що призвело до припинення цих дій [4].

Приклад запитань для обговорення:

- Чи знайома Вам така ситуація? За яких умов та при яких емоційних станах така поведінка можлива?

- Які думки та емоції намагається заглушити та людина, яка вживає наркотичні речовини (алкоголь, наркотики, знеболювальне тощо)?

- Які ще способи виходу із цієї ситуації Ви знаєте? Які із щойно названих способів можна назвати конструктивними, екологічними як для самої людини, так і для оточення?

- Що необхідно людині, щоб вона використовувала конструктивні способи виході із ситуації? Що Ви можете зробити для того, щоб зменшити кількість алкоголю у Вашому житті?

- Чи потрібна для цього група підтримки? Хто може входити до її складу?

II. Спогади Кріса і Таї про те, як вони усвідомлюють, що у їхній сім'ї назрівають проблеми, і вирішують розв'язати їх шляхом обговорення [4].

Запитання для обговорення: 
- Чому, на Вашу думку, можливе погіршення стосунків у сім'ї?

- Якими можуть бути наслідки, якщо залишити все так, як $€$ ?

- Які стосунки у своїй сім'ї Ви хотіли б мати? Чия це ініціатива?

- Хто, на Вашу думку, у сім'ї більш готовий до змін?

- Де Ви можете отримати допомогу? Який досвід можете передати іншим?

III. Кріс описує те, як почав допомагати пораненим ветеранам адаптуватися до мирних умов [4].

- Чи реальна ця ситуація для Вас?

- Чи хотіли б Ви брати участь у подібних заходах?

- Чи хотіли б Ви допомагати іншим адаптуватися до мирних умов після перебування на фронті? Який досвід можете передати іншим?

- Чи маєте Ви ідеї, які можна було б реалізувати?

На нашу думку, ці та подібні епізоди можуть допомогти в усвідомленні проблеми, збагатити життєвий досвід учасників та показати, як можна пережити кризу, оптимізувати процес адаптації. Крім того, бійці можуть ототожнювати себе із головним героєм твору, на початку якого вони знаходяться у рівних з ним умовах, і особисте зростання персонажа мотивуватиме читача до самовдосконалення.

Висновки. Художня література $є$ одним із ефективних способів зцілення від травми та повернення до повноцінного життя, так як дозволяє усвідомити та систематизувати життєвий досвід, поглянути на ситуацію збоку. Образи героїв, з якими боєць може себе ототожнити, відіграють велику роль у знаходженні людиною життєвої опори, а також сприяють її особистісному росту та розвитку.

\section{Список використаних джерел:}

1. Сырчина, М. \& Пьюселик, Ф. (2015). Правило номер один - не лезть солдату в душу, не просить поделиться своїми чувствами. Вилучено з http://fakty.ua/201633-frenk-pyuselikpravilo-nomer-odin---ne-lezt-soldatu-v-dushu-ne-prosit-podelitsya-svoimi-chuvstvami.

2. Ремарк, Е. М. (1974). Час жити і час помирати. (Ю. Петренко, пер. з нім.). Київ: Дніпро.

3. Леметр, П. (2013). До свидания там, наверху. 2013. Вилучено з http://newslab.ru/article/628870.

4. Кайл, К. (2017). Американський снайпер. (А. Поритка, пер. з англ.). Львів: Видавництво Старого Лева.

5. Слюсарчук, Т. (2014). Солдатів треба тренувати у бойових умовах, тільки контрольованих.

Вилучено

http://zaxid.net/soldativ_treba_trenuvati_u_boyovih_umovah_tilki_kontrolovanih_n1322609.

6. Шовкун, Л., Лиховій, Д. \& Лиховій Б. (2016). Війна за ветерана. Як суспільство і держава борються за психологічну адаптацію учасників АTO. Вилучено 3 http://novynarnia.com/2016/12/30/viyna-za-veterana-yak-suspilstvo-y-derzhava-boryutsya-zapsihologichnu-adaptatsiyu-uchasnikiv-ato.

7. Сырчина, М. (2015). Я понимаю, как победить врага, но не знаю, как жить среди своих. Вилучено 3 http://fakty.ua/198584-ya-ponimayu-kak-pobedit-vraga-no-ne-znayu-kak-zhit-sredisvoih-foto.

8. Козлов, В. В. \& Лукин-Григорьев, В. В. (2000) Кризис как фрундаментальная категория жизни. В. В. Козлов (ред.). Ярославль: МАПН.

9. Фоминова, А. Н. (2012). Жизнестойкость личности. Москва: Прометей. 


\title{
SECTION IX. \\ SOCIAL COMMUNICATION AND CULTUROLOGY
}

\author{
DOI 10.36074/25.10.2019.v2.16
}

\section{THE ESSENCE OF THE POSTER AND FEATURES OF ITS COMPOSITE CONSTRUCTION AS A CARRIER OF SOCIALLY SIGNIFICANT INFORMATION}

\author{
Nataliia Ilchuk \\ student \\ National Academy of Culture and Arts Management \\ UKRAINE
}

In modern conditions of society development and information technologies

aimed on perception of information by individuals, their content varies systematically. At the same time, the focus is not on information, but on communications and communication tools that help effectively to convey information to the subject of perception. Therefore, in this context, mass communication through media channels becomes significant [1], and therefore advertising becomes a separate communication tool.

In order to attract consumer's attention, advertisers use not only quality content, but also a range of artistic images and attributes. Increasingly, various advertising techniques are forming large-scale campaigns. In fact, advertising is one of the easiest, laconic and promptly way of communicating a large amount of information to an audience. Therefore, advertising includes both informational and artistic component.

Advertising is a method of transmitting information that is usually intended to give the consumer a definite impression about product, service or idea. There must be a clear logical connection between the idea and its decoration, which is accessible to the average person. The presented information must be objectively interesting and understandable to a wide audience, and the facts must be accurate, verified and true.

Promotional activities take different forms of expression and distribution - vertical and horizontal, as well as mixed. The horizontal form of creation and distribution extends within one homogeneous social group and aims at drawing attention to the same social relations. Instead, the vertical form is directed to supply information within a certain hierarchical structure.

A prime example of a mixed form of information distribution is a poster. The poster is primarily designed to convey information both between participants in one homogeneous group, between homogeneous groups, and different by hierarchical criteria structures. That is why the poster, as an information carrier and communication tool has the most universal character to spread socially significant information.

The poster is one of the oldest advertising and informational means of attracting attention. It incorporates the best achievements of machine and book graphics, 
photography and typography and is an integral part of the visual culture, a powerful mass media and an influence tool on people's minds [2].

The word "poster" appeared at the end of the XIX century as a tracing paper from the German "das plakat"; instead, in England and the United States, the name "poster" came from the word "post"; in France, the word "affiche" - the "poster" took the root [3]. In order to understand the essence of the poster, its importance in the present communication relations, the author proposes to correct the following historical stages of the poster development:

Stage I- Origin of the poster:

1. The beginning of the XV century - thanks to the invention of Johann Gutenberg in 1445 in the city of Mainz, book printing appeared, and therefore books, images of saints, reproductions of paintings, as well as flyers of $15 \mathrm{~cm}$ by $23 \mathrm{~cm}$ which became known as "flying leaves" [4]. Traditionally, the first line was capitalized, the text was usually framed by an engraved ornament with addition of a drawing - this design was used when making posters and functioned until the middle of the XIX century [5].

2. In 1798, the Bavarian Aloise Senerfeld introduced a new technology, which allowed to increase the size of posters and reduce the cost of their production [5]. But such changes did not qualitatively affect its artistic performance.

Stage II - Poster as a self-sufficient artistic object:

1. In 1866 the french Jules Scheuer, the graphic designer and stage decorator, founded a small lithograph in Paris [6]. It was then that the basic principles of the modern poster were formulated - expressiveness (first of all, due to the contrast and bright colors), the ability to perceive the image and text "on the go", laconic and concentration of attention on one main figure. It was J. Shere's posters that first received the author's signature, which made it possible to identify the work as a copyright object [6].

2. The activities of Henri de Toulouse-Lautrec in the 90's of the XIX century, played a key role in the development of the poster. The main works of $\mathrm{H}$. de Toulouse-Lautrec were billboards that were advertising. His first poster was presented in 1889 by "Moulin Rouge" with the dancer La Goule ("Insatiable") and gained public resonance [7].

Stage III - Creation of thematic posters, appearance of a social poster:

1. At the beginning of $X X$ century and during the First World War, a large-scale of propaganda poster was acquired that was used not only for campaigning but also for conscription, military loan signatures, aid to the wounded, and other purposes, often unrelated to one purpose or aim. It is from this kind of poster that the history of the social poster, as a separate subspecies of social advertising, began.

2. In the events of 1917, in particular during the preparation of the so-called "October Revolution", posters began to perform a propaganda function in place of advertising agitation. Thus, the history of the political poster began. Artists of the time, such as Casimir Malevich, Alexander Rodchenko, Shtenberg brothers and El Lisitsky, tried to embody in their works the social changes that were taking place in society.

3. Second World War was a precondition for change in the context of posters within the framework of Soviet policy - the mobilization of all available resources. The history of the Soviet poster began with the work of a group of artists who worked 
under the "TASS Window" project [9]. One week after the outbreak of the war, one of the most famous posters of the war "Motherland calls!" by artist I. Toidze appeared [9].

4. Throughout the existence of the Soviet Union, social advertising displayed virtually every aspect of society - agitated, supported, called for a sense of obligation. The social poster fostered a sense of the common cause among Soviet citizens, instilled Soviet ideals and was widely distributed in all public places.

Visual-graphic expressiveness, embodied in the artistic image of a social poster has great importance for the perception of meaning, it is the carrier of the artistic and aesthetic value of the poster [10]. It is these elements that are crucial for the art of social poster research in the context of design history, theory and methodology.

Therefore, analyzing the historical aspects of the development of the poster as a carrier of social information, we can conclude that today the concept of "poster" should be considered more broadly than it was accepted in the beginning and in the middle of the last century. Poster - a kind of graphics, a work of art, a kind of printed graphics. Laconic, noticeable, often color image with short text, usually made on a large piece of paper that is made for advertising, information, educational purposes [3].

Also, in the author's opinion it is worth considering the types of poster according to their content and thematic direction. You can identify the following types of poster: propaganda (agitation and political), advertising (trade, industrial and entertainment), cultural poster, social.

As was already mentioned, the "propaganda poster" played a significant role in the history of the poster, a concept still relevant today. The propaganda poster is divided into two subspecies: agitation and political [2]. The agitation poster - is one of the most effective forms of political advertising and agitation, it embodies political goals and slogans, covers a variety of topics - the fight for peace, exposure of enemies and more [2].

A separate subspecies of posters, which often use elements of several subspecies - is an advertising poster, among which you can identify trade and industrial and entertaining (movie poster, theater, circus, sports, musical posters, art and cultural events) [2]. A fundamental element of an advertising poster is a sign for goods and services (trademark), trade name or logo. It is these promotional poster elements that are most informative in that they identify the end provider or product for the consumer.

It is also important to pay attention to the cultural poster. This type of poster focuses on issues related to the self-determination of national and ethnic groups, national values, historical and cultural monuments, historical heritage, prominent figures of the past and present; forms a positive image of the future for the younger generation, promotes its cultural and spiritual growth [2].

One of the most important posters for informing society is a social poster that describes and presents in an accessible form basic social norms, universal values. It is the social poster that reflects social behaviors, the specificity of relationships in society, social problems, and general rules of behavior. Also in social posters attention is drawn to such major problems of society as: health of nation, demographic issues, cancer prevention, including children, social support for people with disabilities, promotion of donation, and more. In fact, a social poster is designed 
and created to meet the demand of society as a whole, not to meet the commercial needs of particular groups or individuals.

As was noted, posters have different types and execution techniques. Depending on the style of the poster and its content (commercial, social, cultural), the main object intended to be promoted and the composition that underlies. The poster composition focuses on many aspects of the visual process and is the basis for building an artistic image, fills the idea with content, defines the methodological principles of work [11].

The composition of the poster is not only an expression of the harmonious integrity of the work, but also a means of construction - a composition where all the elements are in the correct relation to each other and interconnected. For all types of images, a mandatory completed composition is required, which will cause the consumer to have an associative series [12].

The poster refers to the front, that is the plane composition. Plane composition is a standalone element that is independent of the objects surrounding it, the boundaries of the image separate it from the environment [12]. In addition, we note that the image format also plays a large role in the consumer's perception of this form of visual communication. The rectangular, elongated vertical format gives the feeling of height, the tendency to go up, the horizontal format - minimizes the sense of clarity and perception, reduces the effect of the image [12].

The composition can be closed (locked), limiting by its form of imagination and perception of the person and open, where all the elements are interconnected in such a way that creates the effect of dynamism and movement [12]. A closed composition is always static, for an open composition, the principle of repetition of a certain element with change in size, color or saturation is most often used [12]. It should also be taken into account that the free space surrounding the composition can be active, that is, to be defined as an independent element of the composition.

The general laws of composition can be defined as follows: the laws of unity, equilibrium, subordination, modification, as well as the law of harmonization [12]. The law of unity is manifested on the basis of the principles of functionality and structure, the law of subordination is realized through the principle of scale and contrast, the law of equilibrium - symmetry, the law of modifications - plasticity and tonality, the law of harmonization is formed on the basis of compositional principles of rhythm and proportionality [12]. Compositional principles, in turn, are revealed through compositional means.

It is necessary to pay attention to the significant factors that, on the one hand, give the composition of the work characteristic features (symmetry, asymmetry, dynamic, static image), and on the other hand - act as artistic means of the composition in the process of creating an artistic image (proportions and scale, meter and rhythm, contrast and nuance, tone and color, etc.) [13]. Symmetry, the simplest and most understandable means of compositional construction of a work, is often used in the design and implementation of the poster. The composite construction of the poster by means of symmetry is considered classical and is predominantly found in the vertical position, which makes the right and left parts of the composition a mirror image [14]. Symmetry requires a clear arrangement of equal parts of the image and the font relative to the axis passing through the center 
of the plane of the sheet. However, the horizontal axis of symmetry is also used, the upper and lower parts of the composition are arranged relative to the axis [14].

Asymmetry is the visual equilibrium of unequal elements of a composition [13]. In contrast to the symmetrical scheme of composition construction, which is dominated by static, calm and steady rhythm of the image, the asymmetry is the basic principles of dynamics, contrast and active rhythmic organization [13].

Important means of the composition include the rhythm, which is simple and complex. A complex rhythm is a regular repetition of several elements or systems that are united by a proportional dependence of rise or fall, when a more complex group of elements of a composition becomes a rhythmic accent [15]. The complex rhythm expresses the dynamics, internal intensity of the visual movement of the elements, accentuates the viewer's attention on the most significant, reveals the main thing among the general [15].

Exploring the concepts and basic principles of composition, it is necessary to mention the contrast. Contrast is the principle of combining elements that are opposite in appearance to the composition [11]. Such a technique as a contrast is necessary for enhancing meaningful accents, giving emotionality to an artistic image, for creating an active dynamic rhythm [11]. Compositional relations, which approach the repetition of different elements, quantities, characteristics of planespatial form are called nuances that can be manifested in form, size, movement, structure, lightness, texture, color [16].

The color of the poster is important value. Operating appropriate combinations of colors, their tone, saturation, contrast the poster sheet is designed as clearly as possible, it is active in the area and at the same time easy to perceive. Color decision of the composition of the poster depends on the peculiarities of his perception and maximum artistic expression. Color may be conditional, may emphasize attention to the sheet, and may have a symbolic meaning [17].

A separate tool that is intended to draw the viewer's attention to the text of the poster is the font. For maximum expressiveness of the text in the poster, the following criteria can be defined - the legibility (readability) of the font, which stands out against the general background, as well as a limited number of words (from 4 to 7) [17].

In summary, the following requirements for text design can be identified, which will provide the best perception of information by the viewer [18]: lettering and letter size (lettering should be simple, letter size - correspond to the area of the sheet); correct color matching to enhance the emotional impact of the text on the reader; background color (font color and background should be contrasting; the sharper the font on the background, the easier it is to perceive); rational length of the line (the line spacing between letters and lines should facilitate the eye perception of individual word groups and move to the next line; the length of the line should correspond to the area of the sheet and the selected font size); line length uniformity.

In view of the above, it can be concluded that a poster is a form of presentation of socially relevant information, but instead, the filling of the poster must comply with the general rules of composition. Properly formulated task, adherence to the compositional rules allows the most effective communication of information to all 
social groups, regardless of their social status or place of residence. It is through compositional techniques that the purpose of the social poster is achieved.

\section{References:}

1. Zrazhevskaya, N. I. (2012). The phenomenon of media culture in the field of social communications (author. diss. ... Ph.D. in Soc. Communication). Kyiv.

2. Andreykanich, A. I. (2013). Ukrainian Culture: Past, Present, Ways of Development. Poster: its types and genres (Vol. 1), (19).

3. Rudenko, E. V., Pavlenko, A. F., Bystryakova, V. N., Kugay, T. A. \& Basanets, O. P. (2017). Technical aesthetics, design and ergonomics. The role of social poster in the development of society, 3(24)

4. Lublinsky, V. (1972). Book in the history of human society. Moscow.

5. Stankevich, N. (2009). Advertising poster from ancient times to the beginning. Twentieth Century Natalia Stankevich. Art Studies 09: Scientific Collection (p. 111-118). Lviv: SKIM.

6. Weill, A. (1997). Three Centuries of French Poster. Interpress Grafik, (4), 16-18

7. Perryusho, A. (2013). Life of Toulouse-Lautrec. St. Petersburg: Ogiz.

8. Grinberg, T. E., Petrushko, M. V. \& Kumylganova, I. A. (2004). Advertising: cultural context. M.: RIP-holding.

9. Evangulova, O. S., Allenov, M. M., Plugin, V. A. \& Sarabyanov, D. V. (1979). History of Russian and Soviet art. D. V. Sarabyanova (Ed.). Moscow.

10. Ismailova, M. S. (2015). Typography as a tool for solving functional and aesthetic aspects in design. Bulletin of Kharkiv State Academy of Design and Arts, (6), 61-70.

11. Shorokhov, E. V. (1986). Composition. M.: Enlightenment.

12. Babka, G. S. (2013). Principles of composite construction in poster. Retrieved from: http://intkonf.org/ru/2013/suchasnist-nauka-chas-vzaemodiya-ta-vzaemovpliv-18-20-11-2013-r/607babka-g-s-printsipi-kompozitsijnoji-pobudovi-u-plakati.

13. A social poster of cultural, historical and topical significance. Retrieved from http://mir.zavantag.com/kultura/507172/index.html.

14. Shevchenko, V. I. Poster composition - a means of constructing the integrity of the artistic form of the visual image. Retrieved from http://librar.org.ua/sections_load.php?s=art\&id=411.

15. Kudin, P. A., Lomov, B. F. \& Mitkin, A. A. (1987). Psychology of perception and poster art. M.: Poster.

16. Bogdanova, L. O. \& Korovkin, G. A. (2017). Summary of lectures in the discipline "Composition". Kharkiv: KhNUMG n. a. O. M. Beketov.

17. Abizov V. A. \& Gryshchenko V. V. (2011). Fine arts. Main factors that determine the development of a modern poster, (1), 71-75.

18. Glazunova, V. V. (1970). Trade advertising: Textbook. The allowance for the merchandiser. Separate technical school of trade. M.: Economics. 


\section{ВПЛИВ КОМУНІКАЦІЙНИХ ВЛАСТИВОСТЕЙ НА БЕЗПЕКУ ЖИТТєДІЯЛЬНОСТІ ЛЮДИНИ}

Самохіна Євгенія Анатоліївна

канд. с.-г. наук, доцент кафедри ТВіППТ та кінології

Сумський національний аграрний університет

Левченко Ірина Володимирівна

канд. с.-г. наук, доцент кафедри ТВіППТ та кінології

Сумський національний аграрний університет

УКРӒ̈HA

Під час переходу людства від індустріальної до інформаційної цивілізації, інформація стала однією з головних складових історичного прогресу.

Інформація - відомості про навколишній світ, процеси, що відбуваються в ньому, які сприймаються людиною або спеціальним пристроєм для ії потреб.

Комунікація - це процес обміну інфрормацією (фактами, ідеями, поглядами, емоціями тощо) між двома або більше особами, спілкування за допомогою вербальних і невербальних засобів із метою передавання та одержання інформації. Без інтенсивного обміну інформацією, постійного інфрормаційного зв'язку з оточуючим середовищем взагалі неможлива нормальна життєдіяльність людей. Проте зараз основну частину інформації люди одержують з різних періодичних видань, телепрограм, радіопрограм, за допомогою мережі Інтернет на різних гаджетах та в соцмережах.

На сьогоднішній день досить актуальними проблемами $\epsilon$ питання взаємозв'язку здоров'я людини та інформаційних технологій. Саме завдяки інфрормаційних і психоемоційних навантажень порушується соматичне та психічне здоров'я населення. За даними 2017 року в Україні налічується приблизно 53 \% осіб, які користуються мережею Інтернет. Це становить 3,5 \% від загальної кількості користувачів у Європі. 96 \% дітей користуються Інтернетом, який став для них природною частиною життя. Сучасних дітей і молодь Інтернет приваблює різноманітним спілкуванням, угамуванням інфрормаційного голоду, пошуком нових фрорм самовираження, анонімністю й віртуальною свободою, почуттям спільності та приналежності до групи. Через перевагу віртуального світу з'являється соціальна неадаптованість та залежна поведінка. Крім цього комунікаційні технології діють негативно на психіку та здоров'я людей, а особливо дітей, також погіршується зір і сон.

Негативним впливом комунікаційних технологій є:

- зомбування особистості (має психотропний вплив. Електромагнітні поля та хвилі електронних приладів вливають на людину таким чином, що викликають зміну людських реакцій на життєві ситуації, що виникають у процесі життєдіяльності;

- маніпулювання суспільною свідомістю (воно спричиняе зміну світосприйняття, спосіб мислення, з'являються нові види відхилень від нормального розвитку);

- поширення слухів (вони являються причиною появи панічних настроїв у суспільстві). 
- дестабілізація суспільства, безпосередній вплив на суспільні процеси (до даної групи відносять спроби порушення життєвонеобхідного комплексу програмно-технічних засобів суспільства, що досягається за допомогою такого виду інформаційної зброї, як «погрози, передані через Інтернет».

Таким чином, визначити однозначно, позитивним чи негативним $€$ вплив соціальних мереж на людину $є$ практично неможливим. 3 одного боку, формується глобальна електронна спільнота, яка може подолати часову та просторову ізольованість окремих культур та народів. 3 іншого боку, формується реальна небезпека уніфрікації культур, руйнування етнічної самобутності. Таким чином, постіндустріальний розвиток світу призводить до необхідності адаптації традиційної культури до вимог сучасних глобальних зв'язків, що дозволить народам зберегти свою самобутність. У різних країнах йде пошук компромісу між формами модернізації і власною самобутністю культур, між співвідношенням їх диференціації і інтеграції.

\title{
Список використаних джерел:
}

1. Яким, Р. С. (2013). Безпека життєдіяльності людини. Львів: Видавництво «Бескид Біт».

2. Щербина, В. (2002). Сітьова кіберкомунікація як соціальний феномен. Соціологія: теорія, методи, маркетинг, (1), 112.

\section{НАРОДНА ПІСНЯ ЯК КУЛЬТУРНИЙ ІДЕНТИФІКАТОР НАЦІЇ}

\author{
ORCID ID: 0000-0003-1993-4236 \\ Шершова Тетяна Вікторівна \\ Національна академія керівних кадрів культури і мистецтв
}

Науковий керівник: Дячук В.П.

кандидат культурології, доцент

Національна академія керівних кадрів культури і мистецтв

УКPÄ̈HA

Українська ідентичність формується в умовах позитивного сприйняття громадянами своєї держави, країни та нації загалом. В умовах політичного конфлікту, який існує між Україною та Росією, існують суттєві розбіжності ціннісних та геополітичних орієнтацій населення. Парадоксально звучить, проте, українці, які виїжджали за кордон, створювали громади, будували українські школи, церкви, намагаючись зберегти національну культуру, відчуваючи себе частиною вільної, української нації, у той час, як деякі українці, проживаючи на території України, пропагують проросійську позицію [2].

Сучасне культуротворче становище демонструє загострення уваги до національних першоджерел та їх відродження. Окрема увага приділяється особистості, яка виступає носієм національного світогляду та здатна зберегти й передати нащадкам культурну пам'ять, яка втілена в народнопісенному виконавстві. Осмислення структури та особливостей народної пісні дозволять 
ідентифікувати культуру окремого регіону та України загалом у глобалізованому суспільстві.

Людина завжди шукала та продовжує шукати сенс власного буття, підтвердження своєї значимості. Ці пошуки часто завершуються глибинними розчаруваннями щодо власних сил, що призводить до заперечення особистості в соціумі. Тому в науковому просторі продовжуються пошуки створення цілісного світоглядно-ціннісного підґрунтя для духовної та творчої самореалізації особистості, що є досить складним процесом в динамічному соціокультурному середовищі. Культурна самоідентифікація можлива лише за умови визнання основних світоглядних цінностей як власного способу буття. Проте протягом життя ці цінності змінюються і людина змушена пристосовуватися до більш зручного для неї середовища, в якому опинилася. Звідси випливає, що культурна самоідентифікація, яка мала б ставити акценти на духовні цінності, перетворилася на інформаційно-знакову систему, в якій переважають стратегії й алгоритми замість образів, символів та категорій.

На культурну ідентифікацію впливають різні її джерела: етнічні, гендерні, національні, релігійні, індивідуальні та територіальні у зв'язку з чим втрачається сенс соціокультурного підґрунтя - відчуття краси, духовності, моралі та творчості. Людина живе у світі ілюзії вибору, коли вважає, що сама обирає систему цінностей, символічні вираження культури. Насправді всі її дії передбачені знаково-інформаційним оточенням. Пристосування до реальності, прийняття існуючої кодифікації формують сучасну самоідентифікацію особистості. Виходом з даної ситуації може бути лише переосмислення культури, яке полягатиме у розумінні сучасної знаковоінформаційної цивілізації та можливості обирати реальність, сприятливу для кожного індивіда.

Українська народна пісня - цілюще джерело та найцінніше надбання в історії нації. Ії мелодії зачаровують та торкаються найпотаємніших глибин людської душі. У народних піснях відображено багатовікову історію українського народу, його життя та побут, боротьбу за визволення. Народна пісня є одним із об'єктів культурної пам'яті, спадщиною, відгуком минулого, яке здатне охарактеризувати культуру певного регіону.

Одним із основних завдань фольклористики є збереження, осмислення та узагальнення багатовікового традиційного культурного досвіду нації, завдяки чому переосмислюється духовна глибина та етногенетична спрямованість фольклору. Відродження української культури потрібно починати з її першоджерел - традицій, обрядів, звичаїв, народної пісні. Фольклор, у цьому відношенні, є потужним ідентифікатором нації. Він, разом із мовою та історією, $€$ визначальним показником національної та етнічної свідомості та акумулятором народної пам'яті. Незважаючи на розмаїття народнопісенних творів, спостерігаємо «вражаючу «бідність» репертуару більшості народних хорових колективів», яка «зумовлена, в значній мірі, недостатньою увагою фахівців до музичного фольклору свого регіону, місцевості, не професіональним підходом і як результат, - кризовий стан сучасного народнопісенного виконавства» [3]. 
Збереження та відродження національних традицій - це збереження цілісності держави, активізація ії̈ потенціалу, зміцнення позицій у світовому співтоваристві, особливо зараз, коли відбувається процес глобалізації.

Саме культурна комунікація здатна покращити міжнародні відносини, збагатити духовний розвиток суспільства, вплинути на економічну, політичну й соціальну сфери, зміцнити та утвердити національну ідентичність та примножити світові культурні надбання.

Народна пісня є вагомим фрактором впливу на етнічну свідомість українців, який здатний піднести моральний і духовний рівень суспільства та нації, оскільки саме в народній пісні закладене історичне минуле, почуття патріотизму та моральні якості. Вона виступає своєрідною народною пам'яттю, засобом передачі культури, традицій та звичаїв своїм нащадкам.

І. Огієнко влучно охарактеризував українську народну пісню: «У який бік життя не поглянемо, скрізь побачимо, як оригінально, своєрідно складав свою культуру народ український. Скрізь, на всьому поклав цей народ свою ознаку, ознаку багатої культури й яскравої талановитості. Візьмемо його пісню: її утворив народ такою, як ніхто з інших народів» [1].

Народна пісня $є$ основою української культури, його духовною спадщиною, вагомою часткою світогляду народу, показником національної свідомості. Мова, історія та фольклор становить основу етнокультури та виступає акумулятором народної пам'яті. Саме у фольклорі зберігаються традиції, норми поведінки, історична пам'ять та спадкова інформація.

Отже, роль української народної пісні - як засобу етнонаціональної соціокультурної ідентичності при подоланні кризових явищ, вихованні патріотичних почуттів та консолідації нації $є$ визначальною. Вона інкультурує особистість, допомагає зберегти національну спадщину, змінює самоусвідомлення українців, підвищує їхню роль і самооцінку у суспільстві та посилює символічну впевненість у цінності власного буття. Перетворення системи культурних образів, оперування категоріальним апаратом і знаковоінформаційними системами складають світоглядно-цілісний фундамент самоідентифрікації особистості.

В складних умовах війни з Росією ми повинні розуміти, що лише доповнюючи один одного, гуртуючись, ідентифікуючи себе з українством, ми зможемо зберегти українську націю. I саме українська народна пісня є вагомим культурним ідентифікатором нації.

\section{Список використаних джерел:}

1. Огієнко, І. (1991). Українська культура : коротка історія культурного життя українського народу. К:: Абрис.

2. Панченко, О. (2014). Українська Австраліана : Полтавщина, Галичина, Боснія. К: Видавництво імені Олени Теліги.

3. Скопцова, О. (2016). Науково-педагогічне осмислення українського народного пісенного виконавства. Педагогічні науки, (66-67), 59-65. 


\section{BLENDED LEARNING IN ESP TEACHING}

\section{Natalya Nikitina \\ National Technical University of Ukraine «Igor Sikorsky Kyiv Polytechnic Institute»}

UKRAINE

The concept of Blended learning is everywhere now. We meet it at any level and any field of education. This instrument gives wide opportunities to combine the work in the class with on-line and distance learning. Today it becomes possible because smart-phone with the internet is available on each desk. Participants of educational process are not ready to decline the real communication in the class and totally move into the digital world. So, blended learning is the formula for realization of real and on-line learning in adequate proportions.

Blended Learning is an educational concept in which a student gains knowledge both online and in person with a teacher. This approach makes it possible to control the time, place, pace and way of studying the material. Blended education allows you to combine traditional techniques and current technology.

Blended learning is a multipurpose device which begins to appear in XX century. The first official reference was made in 1999 by Interactive Learning Center. The center proposed: "... We start to provide online learning software using our own Blended Learning methodology." [1] The first became Boeing who in 1980s started to improve the skills of employees on the job by listening to CDs and watching videos. Since that time a lot of things and the concept itself rather changed. First of all, it is due to the development of computer te

chnologies. Secondly, some changes have appeared due to development of language teaching technologies.

So what is blended learning? There are different models of blended learning implemented in modern schools and institutions. The Face-to-Face Driver includes material which is implied from teacher to student in the class. Digital learning is used for training of obtained knowledge.

Online Driver - most information is in Internet, but the support by teacher is available any time. The next one is flex model - the main part of the program is presented online. The teacher acts as a coordinator, tracking topics that are difficult to understand, and then discussing them in-person in a group or individually. Rotation model - it is an alternation of on-line and off-line (class work) work. The parts of activities are equal. In self-blend model only the most interesting and difficult parts are explained on-line or with the use of computer technology. Online Lab - all experiments are made on-line but on the territory of educational institution and under the guidance of teacher.

So the main part of studying time is still in the class. Students obtain the main, fundamental knowledge in the class. On-line teacher can give additional information on the topic. The discussion can be led in the chat or in any on-line possible way. 
The main task of the teacher is to distribute available time between class work, individual tasks, on-line teaching and on the tutorial work. Here teacher should understand the aims and coals absolutely clear. It is necessary to distinguish the classwork - what should and must be done in the real classroom with the face-toface explanation and what can be mastered at home with on-line support.

The main advantages of blended learning lie in motivation - people nowadays spend more time in gadgets and it is easier for him to get new knowledge and information with the help of electronic devices, therefore, it is easier to motivate them; possibility to save money and time - with the help of on-line technologies students can obtain knowledge sitting at home and without wasting the time and money for the road.

Moreover, blended teaching gives an opportunity to teacher to evaluate, control, estimate, and adjust the teaching material for each student individually. And of course one more huge advantage is accessibility. The participants of on-line part can be anywhere at the moment of teaching-learning.

This model helps students to immerse into the language environment. They watch films or any video material, listen to audio files and information - all this material is authentic. The teacher's role is to be a tutorial, to explain unknown information, correct all kinds of mistakes.

In conclusion, teacher to implement the blended learning model has to make some necessary steps. First of all, definitely, teacher should make a strong decision to use such model. If he only wants to try it will not work, because this model needs a huge preparatory work. Second, the program of the subject must be clear written in accordance with aims, available materials and time distribution. Then, teacher need to decide what part of educational material will be given in the class and which one individually, on-line, etc. the next step is groundwork and search information in internet.

Such kind of foreign language teaching gives wide opportunities for teacher to present any information (lexical, grammatical, etc.) in more effective, useful, impactful, innovative, interesting, understandable way. Students like to work with blended learning model because it is more comfortable, interesting, convenient way to understand the information.

\section{References:}

1. Blended Learning: 5-step transition to blended learning [Blended Learning: perekhod $k$ smeshannomu obucheniyu za 5 shagov]. (2013). Retrieved form https://zillion.net/ru/blog/375/blended-learning-pieriekhod-k-smieshannomu-obuchieniiu-za-5shaghov. [In Russian]. 


\title{
FORMATION OF COMMUNICATIVE COMPETENCES IN THE PROFESSIONAL TRAINING PROCESS OF STUDENTS IN HIGHER EDUCATIONAL ESTABLISHMENTS
}

\author{
Maryna Antonivska \\ teacher \\ Kyiv National University of Culture and Arts \\ UKRAINE
}

Modern society trends in social, cultural, economic and political plans have led to the formation of multicultural society. Multicultural educational society is such an educational space in which live and study students of different ethno-linguistic, religious and socio-economic affiliation [1].

Modern language education requires interdisciplinary integration, orientation on the intercultural aspect of language proficiency.

The transition to the information society needs the development of personality communicative abilities that can simplify it joining the world community. The current stage of societies' development is characterized by increasing openness to the outside world. Nowadays is forming a social order for proficient knowledge of foreign languages. Foreign language learning is aimed at comprehensive development of information-communicative, cognitive, socio-cultural, professional and general cultural competence of students [2].

They should be able to navigate the scientific, methodological and reference literature in a foreign language, using scientific and technical information to study good domestic and foreign experience. These tasks can solve a person-centered, contextual and competency-based approaches to a foreign language learning process. Foreign language acts as a means of forming thoughts. While looking for the necessary information, students turn to various information and educational servers.

Cultural competence implies knowledge of cultural technologies and symbolic objects, the ability to use knowledge in daily practice. There are two aspects of cultural competence: individual and institutional. Individual competence is the student's understanding of the distinctive features of culture and their impact on psychological, world-view and social characteristics. Institutional competence implies cultural awareness and the ability to work in multicultural situations.

An urgent problem is the existence of many mixed forms of culture, caused by the rejection of the norm - social, ethical, linguistic. The scale of new information coming from outside the cultural environment is very intense. In the cultural complex of modern society, there are contradictions between conventional, transmitted from generation to generation and institutionally regulatory elements, which reduces the effectiveness of socio-cultural regulation. With radical social transformations, the need for socialization is increasing, and the importance of topics related to intercultural communication is increasing. The ability to communicate, despite cultural barriers, affects our lives.

Intercultural communication has a number of features that make it more complex than intercultural and interpersonal communication. In order to understand these 
special issues, it is necessary to get a better understanding of the basic components of the communication process [3]. People communicate using two modalities: verbal and non-verbal. The verbal modus includes a language with a set of phonemes, morphemes, vocabulary, syntax and grammar, semantics and pragmatics.

Verbal language is a semantic system that incorporates these components and provides an exchange of ideas, thoughts, and feelings. The non-verbal system includes all non-verbal behavior. Culture influences verbal language. Each language is a unique character system that shows what culture considers important. Culture also influences non-verbal actions.

In foreign language competence, modern researchers understand the set of skills and abilities to perform linguistic actions and operations in a foreign language. Components of foreign language competence are cultural, national, linguistic and technological aspects. It is established that the system can achieve its goal if all its components create unity. For the development of foreign language competence, there must be a certain set of pedagogical conditions, which includes the use of a system of communicative-oriented foreign-language situations with a professional orientation, the use of pedagogical possibilities of dialogue, the provision of educational process with image-schematic clarity.

At the disposal of the teacher there are large reserves to stimulate the interest of students to master a foreign language, which increases the level of foreign language competence of the future specialist.

The main task of education policy is to ensure the modern quality of education, to match its current and perspective needs of the individual and society. The effectiveness of the process of multicultural education by means of a foreign language is conditioned by observance of some principles:

- the principle of didactic correspondence, which is manifested in the selection of material for educational purposes;

- the principle of dialogue of cultures, which is manifested in the construction of didactic model based on contrastive comparative study of cultures.

\section{References:}

1. Sinahatullin, I. (2006). New millennium: role and place of foreign language in multicultural society. State education.

2. Hutorskyi, A. (2003). Key competences as a component of erson-oriented education. Moscow: Linguist.

3. Nunan, D. (1988). The Learner-Centred curriculum. Cambridge: Cambridge University Press. 


\section{SMART-СЕРЕДОВИЩЕ ЯК СКЛАДОВА НАВЧАННЯ У ВНЗ}

ORCID ID: 0000-0002-8745-072X

викладач кафедри іноземних мов

Сумський національний аграрний університет

ORCID ID: 0000-0002-8447-2691
Комарь Віра Іванівна

викладач кафедри іноземних мов

Сумський національний аграрний університет

УКРАÏHA

Зараз система вищої освіти, як і суспільства в цілому, характеризується динамічними змінами в освітніх технологіях. Розвиток інформаційнокомунікативних технологій та Інтернету обумовлює необхідність впровадження у навчальний процес вищих навчальних закладів smart-технологій, які відкривають новий шлях розвитку суспільства XXI століття - Smart-економіки, Smart-освіти, Smart-суспільства. Становлення Smart-суспільства можна назвати глобальною тенденцією. Smart - це здатність об'єкта взаємодіяти, що характеризує інтеграцію у ньому двох чи більше елементів, які раніше не могли бути поєднані, за допомогою Інтернет. Середовище Smart-навчання - e конвергенція ІКТ та інфрраструктури Інтернет [6].

Smart-навчання - це об'єднання навчальних закладів, викладачів і студентів для спільної освітньої діяльності за допомогою Internet-технологій на базі загальних стандартів і технологій [1].

Головна мета Smart-навчання - створення єдиного освітнього електронного середовища, що забезпечує високий рівень конкурентоспроможних робітників за рахунок розвитку в студентів знань i навичок сучасного суспільства XXI століття: співпрацю і комунікацію; соціальну відповідальність; здатність критично мислити; оперативно і якісно вирішувати проблеми. Smart-навчання повинно бути легко керованим, щоб забезпечити організацію освіти, гнучкість навчального процесу та інтегрованим із зовнішніми джерелами [2].

Необхідність розвитку інтегрованого інтелектуального освітнього середовища ґрунтується на достатньому ступені розвитку Smart-технологій та інтенсивності проникнення їх в повсякденне життя. Зазначимо переваги електронного навчання (E-learning): a) можливість у будь-який час і будь-якому місці отримати сучасні знання, що перебувають у будь-якій доступній точці світу; б) доступність вищої освіти особам з особливостями психофрізичного розвитку; в) зручний час і місце для навчання; г) міцне засвоєння знань; ґ) постійний контакт з викладачем; д) індивідуальний графік навчання; е) економія часу та грошей.

Навчальний процес у Smart-середовищі об'єднує: інноваційні та традиційні технології; сучасні програмні засоби; інформаційні ресурси; взаємодію учасників освітнього процесу у відкритій моделі асинхронного індивідуального навчання; бази даних і знань та ін; програмні оболонки, засоби комунікації.

Smart-навчання - це гнучке навчання в інтерактивному освітньому середовищі за допомогою контенту з усього світу, що знаходиться у вільному 
доступі, який дозволяє розширити межі навчання, причому не тільки з точки зору кількості студентів, а й з точки зору часових та просторових показників: навчання стає доступним усюди і завжди [4].

Система Smart-навчання орієнтована насамперед на організацію взаємодії між викладачем та учнями, хоча підходить і для організації традиційних дистанційних курсів, а також підтримки очного навчання. Викладач, маючи власний логін та пароль, має можливість у зручний для себе час оновлювати навчальні матеріали, які знаходяться на сторінці, перевіряти контрольні завдання, доводити до відома студентів необхідну інформацію. Студент може використовувати всі навчальні матеріали для самостійного опрацювання.

Smart-навчання є складовою Smart-освіти, повинно бути легко керованим, забезпечувати організацію освітнього процесу, гнучкість навчального процесу та інтегрованим із зовнішніми джерелами. Smart-освіта - це навчання, яке сприяє розвитку творчості, співпраці, здатності до вирішення завдань, а також навичок спілкування студентів.

Така система навчання, заснована на використанні хмарних сервісів, дозволяє інтегрувати окремі освітні послуги і ресурси, забезпечує більшу зручність для роботи користувачів, збереження даних. 3 цією метою під час уроків розробляється освітній контент з його класифікацією за предметами і темами, що об'єднані в метадані для кращого управління контентом [3].

Створення Smart-середовища, яке засноване на використанні хмарних сервісів, є досить складним процесом. До складу такого середовища входить Smart-підручник.

Наведемо вимоги до технології створення Smart-підручника:

- використання хмарних сервісів та розширених можливостей мультимедійних засобів;

-інтерактивність освітніх інструментів;

- рейтинг знань;

- підписка на доступ і використання;

- групова робота співавторів і читачів в інтернет-просторі;

- створення контенту через особистий кабінет учня.

- забезпеченість навігації по курсу, анотацією;

- структурованість бази даних на сервері та навчального матеріалу;

• наявність посилань на відповідні розділи курсу;

- надання необхідної навчальної інформації;

- можливість вибору інформації в самому курсі;

- посилання до інших корисних джерел.

Отже, використання Smart-середовища надає можливість крім забезпечення засвоєння знань, формування навичок та умінь, мотивувати до навчання, в процесі здійснення інтерактивного навчання, тобто включати в себе мультимедійні фрагменти, зовнішні електронні ресурси, анімації, до яких учень може мати доступ за допомогою Smart-засобів. Важливе значення тут набуває розробка методик навчання, які використовують Smart-технології, оскільки застосування сучасних знань потребує наявності чіткої структури навчання та належного інформаційного наповнення.

Таким чином, впровадження нових технологій в сферу освіти веде за собою перехід від старої схеми репродуктивної передачі знань до нової, креативної 
форми навчання. Одна з головних задач сучасної освіти - це створення стійкої мотивації у студентів до отримання знань, інша - пошук нових форм та інструментів освоєння цих знань за допомогою творчих рішень у студентів.

\title{
Список використаних джерел:
}

1. Биков, В. Ю. (2009). Моделі організаційних систем відкритої освіти. Київ: Аттікас.

2. Розумна освіта для розумного суспільства: Блог ВДПУ ім. М. Коцюбинського. Вилучено 3 http://smarteducatoin.blogspot.com/2016/06/smart-education.html.

3. Гуржий, А. М. (ред.). (2016). Информационно-коммуникационные технологии в профрессионально-техническом образовании. Винница: Нилан лтд.

4. Ахметова, Г. К., Караев, Ж. А. \& Мухамбетжанова, С. Т. (2013). Методика организации повышения квалифрикации педагогов в условиях внедрения системы электронного обучения. Алматы: АО НЦПК «Өрлеу».

5. Положення про електронні освітні ресурси (Наказ Міністерства освіти і науки, молоді та спорту України), № 1060, від 01.10.2012, (редакція від 19.07.2019). (2019). Вилучено 3 http://zakon2.rada.gov.ua/laws/show/z1695-12\#n13.

6. Ташетова, C. C. Smart-образование: тенденции и новые возможности развития педагога системы повышения квалификации. Вилучено 3 http://www.zkoipk.kz/kz/2016smart3/2469conf.html.

7. Тихомиров, В. П. Мир на пути к Smart Education: новые возможности для развития образования. Вилучено 3 http://www.slideshare.net/PROelearning/smart-education-7535648.

\section{IMPLEMENTATION OF THE CONCEPTUAL FOUNDATIONS OF MUSICAL EDUCATION OF PRIMARY SCHOOL CHILDREN BY MUSICAL FOLKLORE}

\begin{abstract}
Oksana Tsuranova
$\mathrm{PhD}$ in Musical Art, Docent

Public Institution "Kharkiv Humanitarian Pedagogical Academy»

Nikolay Andreev

$\mathrm{PhD}$ of pedagogical sciences, Docent Public Institution «Kharkiv Humanitarian Pedagogical Academy»

UKRAINE
\end{abstract}

The revival of national culture and education, which occurred due to sociohistorical transformations in our country, caused the activation of various kinds of musical activity in the aspect of its socio-artistic and educational role in the system of aesthetic means of forming the national consciousness of youth.

The Music Arts Program is the main normative document that defines the content of music education and education in a comprehensive school. It is based on a certain pedagogical concept and determines the method of realization of educational tasks and achievement of the set goal. It reflects the traditions of folk and achievements of modern pedagogy, advanced pedagogical experience. The 
content of the program is aimed at the purposeful use of musical folklore in the education of pupils.

The aim is to study the level of motivation for the influence of folk art on the formation of national consciousness of pupils.

Nowadays the problem of using folklore in musical education of children has become quite acute. Modern elementary school art education envisages the following forms of music education: passive and active listening to music both through various technical means and directly at concerts; musical perception; singing as the main type of musical performance of children; children's musical creativity (playing musical instruments for children, creative tasks in singing and listening to music, rhythmic and musical movements). Each of these forms implies the presence of musical material, which is based on the background of Ukrainian folk art - folklore.

Folklore has absorbed the aesthetic, utilitarian, moral, legal, ideological experience of hundreds of generations. In a broad sense, folklore is a kind of concentrate of the spiritual history of mankind from ancient times to the present. Therefore, one of the important ways of spiritual revival of Ukraine is the involvement of pupils in ukrainian literary and musical folklore.

The essence of the concept of musical education of children on the basis of the Ukrainian national culture lies in the attitude to musical folklore as an integral part of the spiritual life of the Ukrainian people; in recognition of the leading role of folklore in the musical education of children; in the appeal to folk music creativity through the prism of its vital connections with the spiritual, material and practical world of man; in consideration of Ukrainian musical folklore in dialectical unity with the folklore of other peoples; in the study of professional music through the prism of its folklore sources; in revealing the aesthetic content of folk music based on the students' understanding of the essence and features of musical art.

At the same time, it is important not to miss the sensitive period - the younger school age, when children are particularly susceptible to pedagogical influence. Their artistic taste is not developed enough, it is just forming. And if, from an early age, the child listens and sings folk songs, the hearing gradually learns their melodic and rhythmic features, they become familiar, close.

The lullabies, jokes and calendar-rite songs are of great pedagogical importance. Familiarizing pupils with ancient calendar rites contributes to the cultivation of their spiritual culture. Such interesting samples of folklore reflect the best features of the Ukrainian people, in particular, hard work, optimism, respectful attitude of people towards each other. Purposeful involvement of children in this field of culture will help them to cultivate such socially important moral qualities as mutual aid and benevolence.

The conducted researches prove that the pupils are mostly acquainted with the Ukrainian folklore. But the teacher of music art should constantly be in search of new methods and techniques in the lessons on improving the knowledge of children, stimulate their interest in Ukrainian folk art, direct the interests of pupils to the importance of learning Ukrainian songs, dances, rituals, and focus their attention on the great spiritual importance of folklore.

The search for new methods of interest of pupils in oral folk art at the lessons of musical art should be combined with their visual information: trips to the theater, 
holding thematic concerts with the participation of pupils, school theatrical events based on Ukrainian folk rites, the creation of folk groups.

Thus, if musical education in primary school is realized through the means of musical folklore, then Ukrainian folk music will be revealed to children as an integral part of people's life, a holistic phenomenon of their spiritual culture, which will undoubtedly affect the formation and development of musical taste, thinking, speech, imagination, emotional sensitivity and aesthetic development.

\title{
References:
}

1. Ivanitsky, A. (2004). Ukrainian musical folklore. Textbook for higher education institutions. Vinnitsa: NEW BOOK, 320. [In Russian].

2. Pecherskaya, E. (2001). Elementary Music Classes. Kyiv: Lybid. 272. [In Russian].

3. Rostovsky, O. (2001). Methods of teaching music in elementary school. Ternopil: The Educational Book - Bogdan. 216. [In Ukrainian].

DOI 10.36074/25.10.2019.v2.17

\section{АКТУАЛЬНІ ПРОБЛЕМИ ВИЗНАЧЕННЯ ПОНЯТТЯ «КРАЄЗНАВЧА КОМПЕТЕНТІСТЬ У ПЕДАГОГІЧНІЙ ЛITEPATУPI}

\author{
Дубель Ігор Миколайович \\ аспірант кафедри педагогіки \\ Криворізький державний педагогічний університет \\ Науковий керівник: Євтух Микола Борисович \\ д-р. пед. наук, професор, дійсний член (академік) НАПН України \\ Інститут педагогіки НАПН України \\ УКРАÏHA
}

Проблема компетентнісного підходу як методологічної основи освітнього процесу у вищій школі набула актуальності внаслідок реалізації положень Болонської декларації в системі вищої освіти і науки України у 2004-2005 роках. Загальна стратегія переходу вітчизняної системи до компетентнісної моделі була затверджена через Постанову Кабінету Міністрів України «Про утворення Міжвідомчої комісії з підтримки Болонського процесу в Україні», Закон України «Про вищу освіту» від 2014 року, наказ Міністерства освіти України «Про затвердження порядку проведення моніторингу підготовки, перепідготовки та підвищення кваліфікації фахівців у сфері європейської та євроатлантичної інтеграції» та ін. Міжнародна комісія з питань освіти XXI ст., створена при Раді Європи, визначила політику держави в галузі компетентно орієнтованої освіти як постійний процес збагачення особистості знаннями та вміннями, процес розвитку відносин між окремими людьми, групами й народами. Вона виокремила такі основні принципи цієї політики: 
- навчатися жити разом, розвиваючи знання про інших, про їхню історію, традиції і спосіб мислення; оволодівати культурою спілкування;

- збагачувати свій загальнокультурний рівень як своєрідну перепустку до неперервної освіти, основу, яка необхідна для того, щоб навчатися протягом усього життя;

- навчатися жити з посиленням особистої відповідальності, здатності до самооцінювання, самоорганізації [1].

Саме у контексті цих рекомендацій ми вважаємо за доцільне здійснити подальший аналіз поняття «краєзнавча компетентність» (надалі - КК), його значення у процесі підготовки студентів географічних факультетів ВН3.

Питанням визначення краєзнавчих компетентностей займалися такі вчені як В. Кубійович, Г. Карпов, П. Тронько, О. Гончаров, О. Топузов, Л. Жванко, А. Байцар, М. Мирош, Я. Івах, Г. Подибайло, Є. Панкова, О. Лиховид, Г. Попович.

Вивчаючи поняття «краєзнавча компетентність» у педагогічній та методичній літературі, ми бачимо, що більшість авторів трактують його із точки зору освітньої, географрічної, туристичної, історичної чи літературної діяльності. Наприклад, Г. Сорокіна зазначає: «Під краєзнавчою компетентністю фахівця туристичної галузі ми розуміємо наявність у майбутніх фахівців краєзнавчих знань та досвіду краєзнавчої роботи, необхідних для ефективної професійної діяльності робітників в туристичній сфері» [2]. Л. Вішнікіна та О. Топузов подають більш широке визначення: «Краєзнавчу міжпредметно-інтегральну компетентність визначаємо як таку, що відповідає здатності учня застосовувати географічні знання, вміння, навички, способи діяльності та ставлення щодо краєзнавчих проблем, які належать до певного кола різних навчальних предметів й освітніх галузей, і формується у процесі навчання географії. До таких компетентностей також належать, зокрема, природничо-математична, країнознавча, краєзнавча, туристична, картознавча, демографічна, економічна тощо» [3].

С. Шемшурина у своїй дисертаційній праці виводить наступне тлумачення: «Краєзнавча компетентність розглядається як сукупність знань, умінь, навичок і досвіду, необхідних для продуктивної пізнавально-краєзнавчої діяльності та виявляється в усвідомленні цінностей рідного краю» [4].

На думку А. І. Алейник, «краєзнавча компетентність - це занурення учня у всебічне вивчення їм рідного краю, засвоєння краєзнавчого матеріалу, природознавчого, соціального, етнокультурного змісту і вираз до нього емоційно-ціннісного ставлення» [5].

Очевидно, що дослідники одностайні в думці про те, що краєзнавча компетентність - це знання, уміння і навички (ЗУН) краєзнавчого змісту, засвоєні і застосовувані учнем/студентом в його діяльності. Детально вивчаючи кожне із вище запропонованих визначень, зазначаємо, що найбільш універсальним воно є у Г. Сорокіної, яка акцентує саме на ЗУН та майбутній професійній діяльності студентів у сфері туризму. Однак, на нашу думку, воно $\epsilon$ дещо специфічним (з точки зору підготовки туристів) та позбавленим важливих деталей, які ми знаходимо у Л. Вішнікіної та О. Топузова: крім визначення КК як ЗУН, вони наголошують на їі міжпредметно-інтегральній природі, відкриваючи набагато ширше поле для дослідження та тлумачення. 
Але незважаючи на це, автори розглядають КК як одну із компетентностей, отримуваних у процесі навчання географії. Тобто таке тлумачення також $€$ певною мірою вузькоспецифічним. Якщо ж намагатися вивести якомога загальне визначення, то слід звернути увагу на варіант, запропонований С. Шемшуриною: не відмовляючись від тлумачення КК як ЗУН для професійної діяльності, вона зачіпає і аксіологічний ракурс проблеми. Про емоційноціннісну, соціокультурну складову КК говорить і А. І. Алейник, віддаючи перевагу чуттєво-образному сприйняттю учня під час навчання.

Згадані нами перші два визначення краще підходять, на нашу думку, під час фахової підготовки студентів у ВН3, а останні два - при шкільному навчанні та гуртковій роботі з учнями (що не зменшує їх важливості при дослідженні поняття «краєзнавча компетентність»). Відповідно, ми можемо зробити проміжний висновок: поняття «краєзнавча компетентність» потребує більш конкретного витлумачення як міждисциплінарно-аксіологічного феномена, який наразі недостатнім чином описаний у педагогічній літературі.

На основі вищезазначеного аналізу, у нашому дослідженні ми пропонуємо застосовувати власне визначення краєзнавчої компетентності як інтегрального науково-соціокультурного набору знань, умінь навичок, здобутих під час фахового навчання, який дозволяє оперувати методами та засобами профресійної діяльності задля ефективного вирішення аксіологічних, практичних і теоретичних завдань краєзнавства.

Також необхідно зазначити, що подальше теоретичне уточнення поняття «краєзнавчі компетентності» буде однозначно зумовлювати потребу пошуку ефрективних дидактичних механізмів для їх практичного набуття студентами профрільних спеціальностей.

\section{Список використаних джерел:}

1. Свириденко, Т .І. (2010). Модель моніторингу професійної компетентності викладача ВНЗ ІII рівнів акредитації. Теорія та методика управління освітою. Електронне наукове фахове видання Університету менеджменту освіти, (4), 1-12. Вилучено із: http://tme.umo.edu.ua/docs/2/09svipcm.pdf.

2. Сорокіна, Г. О. (2013). Туристсько-краєзнавча практика як необхідна умова фахової підготовки фахівців туристичної галузі. Вісник Луганського національного Університету ім. Тараса Шевченка. Частина III, (277), 130-135. Вилучено із: http://tourlib.net/statti_ukr/sorokina3.htm.

3. Вішнікіна, Л. \& Топузов, О. (2017). Структура предметної географічної компетентності учнів (рекомендації для вчителів географії). Українська професійна освіта, (1) 103-110.

4. Шемшурина, С.А.(2011). Формирование краеведческой компетенции подростков в дополнительном образовании. (автореф. дис. канд. пед. наук). Удмуртский. государственный университет, Ижевск, Российская Федерация.

5. Алейник, А. И. (2013). Развитие познавательного интереса младших школьников в образовательном процессе на основе краеведческого материала. Белгород: БелГУ. 


\section{ВАЖЛИВІСТЬ ВОЛОДІННЯ ІНОЗЕМНОЮ МОВОЮ НА ШЛЯХУ ДО ЄВРОІНТЕГРАЦІЇ}

ORCID ID: 0000-0002-8447-2691

Комарь Віра Іванівна

викладач кафедри іноземних мов Сумський національний аграрний університет

ORCID ID: 0000-0002-8745-072X

Лук'янова Юлія Миколаївна

викладач кафредри іноземних мов

Сумський національний аграрний університет

УКРАÏHA

Актуальність теми обумовлена тим, що у сучасному європейському середовищі багато уваги приділяється важливості іноземної мови, що зумовлює необхідність появи фрахівцівіз різних спеціальностей з високим рівнем володіння іноземною мовою.

Згідно результатів онлайн-дослідження українського каналу новин 112.TSN, що було проведено в 2015 році: близько 89\% українців вчили англійську мову, проте лише $18 \%$ володіють нею на рівні вище середнього. Порівняно з країнами Європи, Україна відстає в готовності населення спілкуватися іноземною мовою. Дані Євробарометра "Європейці та їх мови" показують, що більше половини жителів країн $€ С$ знають щонайменше дві мови, а 38\% європейців вільно володіють англійською [1].

Тож питання мовної компетенції стоїть дуже гостро. Необхідність володіння англійською мовою зумовлено багатьма причинами такими як трудова міграція, міжнародні освітні проекти та конкурентоздатність фахівців на світовому рівні. Хоча мовами міжнародного спілкування в $€ C \in$ фрранцузька, німецька, іспанська, італійська, все ж англійській мові надається перевага, оскільки саме вона широко використовується в країнах $Є С$.

Дуже багато риторики присвячено різноманіттю мов, однак англійська займає все більше простору в європейських інституціях, в корпоративному світі і в засобах масової інформації та багатьох видах міжнародної діяльності [2].

Слід зазначити, що ЄС є прикладом загального поширення англійської мови к мови міжнародного спілкування в європейському суспільстві. Отже володіння англійською мовою $€$ надзвичайно важливим показником професійної спроможності фахівця на ринку праці європейських країн.

Мовне й культурне різноманіття, яке $є$ невід'ємним поняттям активного європейського громадянства, є компонентом європейської ідентичності [3]. Мовна ситуація в країнах ЄС змінюється від мовної політики Європейського Союзу.

Одна з цілей мовної політики полягає в тому, щоб кожен європейський громадянин володів двома іноземними мовами на додаток до їх рідної мови. Українці, в свою чергу, розуміють необхідність знати мови - 2/3 респондентів запевнили, що планують їх вивчати. Найбільш популярною серед іноземних мов $є$ англійська - її планує вивчати половина опитаних, а 97\% хотіли б, щоб його вивчали діти" [1]. 
Сьогодні професійно-орієнтоване викладання мов визначено основним напрямком рефрормації процесу освіти. Таке викладання базується на потребі студентів у розумінні мовної специфіки у контексті майбутньої професії.

У той же час іноземна мова як академічна дисципліна має базуватися на професійному розвитку студента, тому що вона $є$ прямо залученою у процес здобуття наступних фрахових компетенцій здобувача вищої освіти:

- здатність використовувати набуті професійні навички;

- критично-аналітичне мислення;

- здатність приймати відповідальні рішення;

- незалежність та креативність; - концентрація на ефрективності та якості виконання поставлених завдань;

- комунікативна культура;

- здатність до кооперації та менеджменту [4].

Резюмуючи вищенаведене, можна запропонувати такі шляхи щодо успішного оволодіння іноземною мовою: 1- викладання дисципліни «Іноземна мова» потребує якнайбільшої інтеграції з усіма базовими дисциплінами; 2навчити студентів використовувати іноземну мову як засіб підвищення професійних знань та як інструмент фахової діяльності; 3- викладання має включати використання різноманітних методів, що забезпечать засвоєння лінгвістичних навичок у контексті професійних знань майбутнього фахівця. Тож запровадження таких пропозицій у закладах вищої освіти $€$ вимогою сьогодення на шляху до євроінтеграції.

\section{Список використаних джерел:}

1. Скільки українців володіють англійською мовою. (2015). Вилучено 3 http://tvoemisto.tv/news/skilky_ukraintsiv_volodiyut_angliyskoyu_movoyu_infografika_75095.ht $\mathrm{ml}$.

2. Special Eurobarometer 386: EUROPEANS AND THEIR LANGUAGES. (2012). Retrieved from https://web.archive.org/web/20160106183351/http://ec.europa.eu/public_opinion/archives/ebs/e bs_386_en.pdf.

3. Hartmut Behr \& Yannis A. Stivachtis. (2015). Revisiting the European Union as Empire. Retrieved from

https://books.google.com.uabooks?hl=uk\&lr=\&id=xMgBCgAAQBAJ\&oi=fnd\&pg=PA134\&dq=eng lish+language+european+union\&ots=zqGrv2q|OF\&sig=tPA3j|Yth7eQWQ77BTrxCH85dig\&redir_ esc=y\#v=onepage\&q=english\%20language \%20european\%20union\&f=false.

4. Полозова, В. П. \& Правдина, М.В.(2013). Иноязычная подготовка студентов технического ВУЗа: вопросы интеграции. Вестник Нижегородской государственной сельскохозяйственной академии, 184-188. 


\title{
ДО ОНОВЛЕННЯ КОНЦЕПТУАЛЬНИХ ЗАСАД СЕРЕДНЬОЇ ОСВІТИ: РАЦІОГУМАНІСТИЧНА ПАРАДИГМА
}

\author{
Дічек Наталія Петрівна \\ д-р. пед. наук, профресор, завідувач відділу історії та фрілософії освіти \\ Інститут педагогіки НАПН України
}

УКРАÏHA

У добу незалежності розвиток освіти було визнано умовою і засобом входження України до кола розвинених країн світу, пріоритетом її державної політики [7; 8]. На жаль, як зазначає академік НАПН України В.Андрущенко, належного розуміння і всебічної підтримки і від владних структур, і від громадянського суспільства ця стратегія не набула [1], хоча розвиток особистості і формування громадянина, здатного самостійно і вільно мислити й діяти, проголошувався всіма офіційними документами, які приймалися владою. Згідно з ними після 1991 р. в нашій державі розпочалося оновлення теоретико-методологічних засад освіти, зокрема й середньої. У цьому процесі спостерігалося кілька ключових тенденцій, серед них: забезпечення й розширення культурно-національного складника освіти як стрижневого напряму її змін; спрямування змісту й технологій навчання у річище гуманізації; європоцентричність трансформаційних процесів; прискорення впровадження в освітню галузь інформаційно-комунікативних технологій й ін. Згадані тенденції були представлені у Національній доктрині розвитку освіти України у XXI столітті [9].

Як свідчать дані, у розробленні Доктрини взяли участь десятків тисяч освітян, науковців, практичних політиків, діячів науки і культури, пересічних громадян, які надсилали свої пропозиції, брали участь в дискусіях і обговореннях її проекту [1]. Окрім окреслення шляхів розвитку освіти в контексті «постсоціалістичних перетворень», в умовах демократизації життя й ринкових перетворень, в ній наголошувалося на актуалізації знання у світовому глобалізаційному просторі і необхідності «збереження і розвитку інтелектуального потенціалу нації» [9].

У напрямі узасаднення шляхів гуманізації й індивідуалізації шкільної освіти, забезпечення поступу інтелектуального потенціалу нації важливу роль відіграли теоретичні напрацювання доктора психологічних наук, членакореспондента НАПН України, професора Г.Балла, який обґрунтував концепцію раціогуманізму. На наше переконання, її положення заслуговують на подальше розроблення і впровадження, особливо у контексті сучасного зростання міжкультурної комунікації та розвитку інформаційного суспільства.

Пояснимо, що поняття «гуманізм» учений розглядав як світоглядну орієнтацію, в основі якої «віра у широкі можливості гармонійного розгортання продуктивних можливостей людини» [5], а поняття «раціоналізм» як характерну для людини якість, тому раціоналізм, писав він, є одним з аспектів гуманізму. Раціогуманізм Г.Балл тлумачив як принцип, згідно з яким у світоглядній площині інтелектуальна культура і наука, як її осердя, мають бути визнаними одними з найпосутніших надбань людства, а в антропологічній 
площині - як багатство, що має бути використане (у гармонічній взаємодії $з$ іншими складниками культури) для розширення знань про людину та їх використання на ії користь [там само]. Зміст гуманізації освіти за Баллом полягає у сприянні особистісному розвитку учня, забезпеченні гармонізації цього розвитку [2].

Ще на початку 1990-х років Г.Балл, досліджуючи психологічні аспекти побудови змісту і форм освіти в незалежній Україні на гуманістичних засадах [4], писав, що лише гуманістична ідея висуває на передній план діалогічну стратегію психологічних впливів (діянь), що використовуються з педагогічною метою. Натомість авторитарна ідея надає перевагу імперативній стратегії впливів, а в ліберальній пріоритетну позицію посідає маніпулятивна стратегія [4]. Варто підкреслити, що Георгій Олексійович був активним прихильником діалогічної стратегії в освіті, вважав, що діалогічний підхід до навчання потрібний і для формування здатності змінювати форму і зміст освіти, і для полегшення спілкування учнів з широким інформаційним середовищем, де циркулюють різноманітні погляди, до яких треба ставитися свідомо, критично, а також і для стимулювання учнівської творчості [6].

Враховуючи й характерні для традиційної української ментальності риси індивідуалізму й волелюбності у поєднанні з поетичною спрямованістю свідомості, християнською мораллю й інтенсивним культурним обміном 3 іншими етносами, вчений виснував, що у «довгочасній перспективі $\epsilon$ сприятливі передумови для розвитку соціокультурних й освітніх систем відповідно до гуманістичних й діалогічних засад» [4]. Для цього слід поєднувати традиції з різнобічним використанням науково-технічних і культурних надбань сучасності.

Г. Балл обґрунтував визначення особистості як поєднання різноманітних за змістом та ступенем складності груп її виявів, наголошуючи, що учня (особу) необхідно вивчати не лише з метою попередження можливих негативних ефектів, а й для передбачення максимально можливого сприяння «продуктивному розкриттю і подальшому збагаченню своєрідних індивідуальних можливостей кожного учня» [3]. Таке сприяння може бути успішним лише за умови ретельної уваги до індивідуальних особливостей учня у педагогічному керівництві його діяльністю, у її психологічному супроводі, у професійній орієнтації тощо» [4]. Він наголошував, що сутнісний зміст «спрямованих педагогічних впливів», має полягати у «прилученні кожного учня (студента) до культури (і загальнолюдської, і національної, і професійної) в єдності її нормативно-репродуктивних і діалогічно-творчих складників, у сприянні розвиткові учня як носія (і не лише носія, а активного носія - суб'єкта) культури [3]. Саме у широкому прилученні молодої людини до культури він власне вбачав головну місію особистісно орієнтованої освіти.

Окреслюючи провідні напрями гуманізації освіти, вчений виділяв: гуманізацію її цілей (формування вільного, розвиненого, високоморального, творчо активного, соціально зрілого фахівця); гуманізацію змісту освіти (на основі реалізації принципу історизму, який передбачає репрезентацію еволюції людських знань про природу, суспільство і мислення; включення знань про становлення i розвиток загальнолюдських цінностей та гуманістичних поглядів мислителів і вчених як творців духовної культури людства; гуманізацію методів навчання (гуманістичний підхід до організації 
навчально-пізнавальної діяльності суб'єктів навчального процесу, розроблення особистісно орієнтованих технологій навчання і виховання) [6].

\section{Список використаних джерел:}

1. Андрущенко, В.П.(2014). Освітня політика в умовах входження України в Європейський простір. Вилучено з http://dspace.khntusg.com.ua/bitstream/123456789/942/1/3.pdf.

2. Балл, Г. О. (2002). Принципи гуманізації в загальноосвітній та професійній підготовці учнівської молоді. В Балл, Г. О.. Бастун, М. В., Гордієнко, В. І., Красильникова, Г. В., Красильников, С. Р., Крюкова, Д. Ф., ..., Помиткін, Е. О. Психологія особистісно орієнтованої професійної підготовки учнівської молоді (с. 30-53). Київ-Тернопіль.

3. Балл, Г. О. (2006). Гуманізація освіти у контексті категорій «особистість» $i$ «культура». В Психология в рациогуманистической перспективе: Избр. Труди (с. 306-317). Киев: Изд. «Основа».

4. Балл, Г. О. \& Волинець, А. Г. (1995). Ідейні підвалини розбудови освітніх систем та критерії ефективності їх функціонування. Псих. проблеми навчання, виховання, активності та розвитку особистості: матер. звітної наук. сесії Ін-ту психології (с. 51-59), 10-11 лютого 1994. Київ, Україна.

5. Балл, Г. А. Рациогуманизм как мировоззренческий и методологический принцип. Глобальна біоетика: сучасні виміри, проблеми, рішення: матер. III Міжнар. симпозіуму з біоетики. (с. 22-24), 2004. Київ, Україна.

6. Балл, Г. О. (1996). Про реалізацію гуманістичних принципів у розбудові освіти й пед. діяльності. В Психол. аспекти гуманізації освіти: кн. для вчителя (с. 2-22). Київ-Рівне.

7. Державна національна програма «Освіта»: Україна XXI століття. (1993). Освіта, (44-46), 113.

8. Про освіту (Закон України). 2145-VIII. (2014). Вилучено 3 https://zakon.rada.gov.ua/laws/show/2145-19.

9. Національна доктрина розвитку освіти України у XXI столітті. Вилучено 3 repository.Idufk.edu.ua/.../1/natsionalna\%20doktryna.pdf.

DOI 10.36074/25.10.2019.v2.19

\section{МІСЦЕ ТА РОЛЬ ПРОФІЛЬНОГО НАВЧАННЯ СТАРШОКЛАСНИКІВ У РОЗВИТКУ СУЧАСНИХ ЗАГАЛЬНООСВІТНІХ ШКІЛ}

Загородня Алла Анатоліївна канд. пед. наук, доцент, провідний науковий співробітник відділу історії та фрілософії освіти Інституту педагогіки НАПН України

УКРАЇНА

3 метою професійного самовизначення та всебічного розвитку особистості, відповідно до «Концепції профрільного навчання» (2013) та «Концепції Нової української школи» (2016), одним із пріоритетних завдань реформування сфери загальної середньої освіти в Україні є організація профільного навчання старшокласників, створенням умов для розвитку творчої особистості, здатної 
ефективно працювати та навчатися упродовж усього життя. Як наслідок, за останнє десятиліття в освітньому просторі системи загальної середньої освіти активно почали функціонувати ліцеї, гімназії, колегіуми, де профільність старшої школи втілюється на практиці.

Профільне навчання ми розглядаємо як вид диференційованого навчання, який передбачає врахування освітніх потреб, нахилів та здібностей учнів і створення умов для навчання старшокласників відповідно до їхнього професійного самовизначення, що забезпечується за рахунок змін у цілях, змісті та структурі організації навчання [3].

На думку Л. Покроєвої профрільне навчання - це засіб диференціації та індивідуалізації навчання, який враховує інтереси, нахили та здібності учнів, створює умови для навчання відповідно до їх професійної орієнтації [4]. На переконання Р. Бєссонова, профільне навчання слід розглядати як освітній процес в профільних класах ліцеїв та гімназій, що зорієнтований на соціальнопрофесійне самовизначення старшокласників шляхом диференціації навчання на підставі врахування здібностей і інтересів [1].

Впроваджуючи європейські стандарти загальної середньої освіти, Україна пішла шляхом профілізації школи, у зв'язку з чим перед переходом у старші класи середньої школи 10-12 кл. кожен учень має самостійно визначитися зі своєю майбутньою професією і обрати той чи інший профіль навчання згідно зі своїми здібностями та уподобаннями. Оскільки цей вибір передбачає поглиблене вивчення циклу споріднених предметів за відповідним напрямом, як: суспільно-гуманітарний, фрілологічний, художньо-естетичний, природничоматематичний, технологічний та спортивний.

Базові шкільні предмети $€$ обов'язковими до вивчення незалежно від обраного профілю навчання, а от профільні предмети шкільної програми вивчатимуться на різних рівнях в залежності від обраного профілю: базовому, де зміст винесеного до вивчення шкільного матеріалу зводиться до мінімуму (наприклад, математика у фрілологів); академічному - предмети не $є$ профільними, але споріднені й тому вивчатимуться у ЗВО (фізика у хімікобіологічному профілі); профрільної підготовки - поглиблене вивчення предметів з орієнтацією на майбутню професію (фізика і математика у фрізикоматематичному профрілі).

Для глибокого розуміння сутності, місця та ролі профрільного навчання у розвитку сучасних загальноосвітніх шкіл, з'ясовуємо його цілі та зміст. Складовими цілей профільного навчання $€$ формування в учнів соціальнопедагогічних, організаційно-методичних та універсальних компетенцій необхідних для успішної самореалізації індвіда в суспільстві [2, с. 9].

Серед головних чинників реалізації змісту профільного навчання слід виокремити наступні: наскрізний процес навчання який фрормує цінності; набуття компетентностей для життя; пріоритет національних та культурних цінностей; оволодіння саморефлексією; загальнокультурна грамотність; свобода прояву творчості; орієнтація на потреби учня (дитиноцентризм) та ін. [5].

Підсумовуючи вищевикладене, зазначимо, що організація профрільного навчання в старших класах середньої загальноосвітньої школи надає можливість забезпечити отримання якісного рівня знань 3 профрільних 
предметів на рівні сучасних вимог, задовольнити потреби учнів у їх професійному самовизначенні, а також підготувати конкурентоспроможного випускника, майбутнього фахівця здатного гідно працювати в сучасних умовах.

\section{Список використаних джерел:}

1. Бєссонов, Р. (2017). Інтенсифікація і оптимізація процесу навчання учнів профільних класів. Педагогіка, (1), 28-33.

2. Вольянська, С. (2006). Організація профрільного навчання в загальноосвітній школі в умовах регіону. (автореф. дис. ... канд. пед. наук). Харків. держ. пед. ун-т ім. Г. Сковороди. Харків, Україна.

3. Загородня, А. (2018). Диференціація змісту навчання у старшій школі як ефективна умова реалізації особистісно-орієнтованої парадигми освіти. Педагогічна освіта: теорія $i$ практика: зб. наукових праць (Серія: Педагогіка), (25), 59-65.

4. Покроєва, Л. (2007). Структура, моделі профрільного навчання. Організація профільного навчання в старшій школі. Н. Мурашко (упоряд.). Київ: Шк. світ.

5. Самодрин, А. (1998). Організація діяльності профільно-диференційованої школи. Рід. шк., (6), 60-63.

\section{ОСОБЛИВОСТІ ВИКЛАДАННЯ АНГЛІЙСЬКОЇ МОВИ ПРОФЕСІЙНОГО СПРЯМУВАННЯ КУРСАНТІВ І ПРАЦІВНИКІВ ОРГАНІВ ВНУТРІШНІХ СПРАВ (НА МАТЕРІАЛІ АНГЛІЙСЬКОÏ МОВИ)}

Болкарьова Олександра Вікторівна

старший викладач кафедри українознавства та іноземних мов Дніпропетровський державний університет внутрішніх справ

УКРӒ̈НА

Культура спілкування відіграє значущу руль у спілкуванні та є предметом дослідження багатьох наук - фрілософських, педагогічних, психологічних. У сучасних умовах встановлення та підтримка міжнародних контактів, розвиток будь яких сфрер діяльності, залучення України до проведення міжнародних масових культурних і спортивних заходів можливо за наявності високого рівня знання іноземної мови. Саме тому, проблема підвищення ефективності та вдосконалення професійної підготовки курсантів i працівників органів внутрішніх справ стає актуальною.

Спілкування відбувається в межах конкретних професійних потреб 3 використанням іноземної мови, зокрема англійської. Для досягнення висого рівня викладання іноземної мови викладач має враховувати особливості слухачів, використовувати спеціальні навчальні техніки та прийоми, що дозволяють оптимально підібрати метод відповідно до рівня знань, потреб та інтересів курсантів/працівників. Важливим стає використання різних методів навчання, таких як:

- метод конкретної ситуаціях (розвиває здібність розуміти, аналізувати, самостійно приймати рішення); 
- метод тренування чуйності (розвиває вміння управляти власним стилем поведінки та прийнятність до емоційного стану інших людей);

- метод занурення (долає вікову та особисту інерційність психологічних процесів;

- метод мозкового штурму (групове розв'язання творчої проблеми, активізую творчу думку;

- метод багатомірної матриці (реалізує принцип системного аналізу);

- метод інверсії (розвиває діалектику мислення);

- метод діалогового спілкування (формує діалогічне розуміння особистістю у вільному культурному спілкування з іншими людьми і з собою);

- метод ділової гри / поліцейський квест (забезпечує максимальне емоційне залучення учасників у події, допускаючи можливості повернути їх хід).

Розвиваючи культуру мовлення через призму іноземної (англійської мови) можливим стає використання різноманітних інтерактивних технологій, як кооперативне навчання (робота в парах, малих групах), колективно-групове навчання (обговорення проблеми, мікрофон, мозковий штурм, аналіз ситуації, вирішення проблем, дерево рішень), ситуативне моделювання (імітаційні ігри, спрощене судове рішення, квест-технології), опрацювання дискусійних питань. Саме таке різноманіття забезпечує зацікавлення та оволодіння мовної компетенції курсантів/працівників 3 отриманням високих результатів. Мовленнєва взаємодія курсантів може проходити як за співучастю викладача, так і без неї, з використанням найрізноманітніших форм: пари, тріади, невеликі групи, вся група. Курсанти оволодівають усіма чотирма видами мовленнєвої діяльності на усіх рівнях при обмеженому використанні рідної мови. Об'єктом оцінки є не тільки правильність, але й швидкість виконання. Для досягнення комунікативної компетенції, комунікативних вмінь, сформованих на основі мовних знань, вмінь і навичок, викладач іноземної мови має використовувати новітні методи навчання, що об'єднуються комунікативними та пізнавальними цілями. Інноваційні методи навчання іноземних мов, які базуються на гуманістичному підході, спрямовані на розвиток і самовдосконалення особистості, на розкриття ії резервних можливостей і творчого потенціалу, створюють передумови для ефективного поліпшення навчального процесу у вищих навчальних закладах. Вивчення іноземної мови у вищому навчальному закладі спрямоване насамперед на оволодіння комунікативною компетенцією, під якою розуміють "сукупність знань про спілкування в різноманітних умовах і з різними комунікантами, а також знань вербальних та невербальних засад інтеграції, умінь їх ефективного застосування в конкретному спілкуванні вролі адресанта і адресата" [2] Проблемам дослідження мовленнєвої підготовки курсантів присвячені праці В. Лукашевича, В. Синьова, О. Бандурки та ін.; культуру мовлення розглянуто в працях В. Клименко, А. Токарської, Т. Гороховської.

Т.В. Гороховська, зокрема, розглядає й трактує культуру професійного мовлення як складову професійної культури, як інтегровану якість особистості, що проявляється в досконалому володінні нормами літературної мови та вмінні їх правильно, точно, виразно, комунікативно доцільно застосувати в процесі передачі своєї думки у фаховому писемному та усному спілкуванні, позитивному ставленні фахівця до мовленнєвої діяльності як складової успішної професійної самореалізації [1]. Досліджуючи й аналізуючи психолого- 
педагогічні засади й умови процесу формування культури професійного мовлення майбутніх працівників ОВС, Т.В. Гороховська виділяє три головні компоненти культури професійного мовлення курсантів:

1) мотиваційний (передбачає інтеріоризацію загальнокультурних, національних, мовних, професійних цінностей суспільства в особистісні, перетворення їx у відповідні професійні якості, що проявляються в повсякденній поведінці як складові елементи культури професійного мовлення на емоційно-чуттєвому рівні);

2) когнітивний (спрямований на оволодіння курсантами необхідною мовленнєвою інфрормацією);

3) діяльнісний (потребує оволодіння необхідними прийомами, що відповідають чотирьом формам мовленнєвої діяльності: говоріння, читання, слухання, письмо) [1].

Мотивація навчального процесу є центральною у педагогічному аспекти, оскільки від нього залежить більна частина позитивного отримення результату. Аналіз психологічних і педагогічних наукових джерел засвідчує, що проблеми формування навчальної мотивації розглядали у своїх працях як вітчизняні, так і зарубіжні дослідники [3]. Формування мотивів до вивчення іноземної мови у різних контекстах у сучасній українській педагогічній науці активно досліджували викладачі Національної академії Прикордонних військ України ім. Богдана Хмельницького [4], Вінницького державного педагогічного університету ім. Михайла Коцюбинського та інших вищих навчальних закладів освіти України [5].

\section{Список використаних джерел:}

1. Гороховська, Т. В. (2007). Формування культури професійного мовлення майбутніх працівників органів внутрішніх справ (автореф. дис ... канд. пед. наук). Нац. акад. держ. прикордон. служби України ім. Б. Хмельницького. Хмельницький, Україна. Вилучено 3 http://www.nbuv.gov.ua/ard/2007/07gtvovs.zip.

2. Ніколаєва, С. В. (ред.). (2003). Загальноєвропейські рекомендації з мовної освіти: вивчення, викладання, оцінювання. Київ: Ленвіт.

3. Ильин, Е. П. (2000). Мотивация и мотивы. СПб: Питер.

4. Сінкевич, С. В. (2001). Чинники, що впливають на формування ціннісного ставлення курсантів ВУЗів до вивчення іноземної мови. Морально-психологічне забезпечення службової та навчально-виховної діяльності: матеріали міжвузівської науковотеоретичної конференції (Ч. II), (17), 22-25. Хмельницький, Україна: Вид-во Національної академії.

5. Яцишин, О. М. (2002). Роль професійно спрямованого навчання іноземної мови у формуванні мотивації учбової діяльності студентів. Наукові записки Тернопільського державного педагогічного університету, (9). 28-31. 


\title{
РЕЗУЛЬТАТИ ПЕДАГОГІЧНОГО ЕКСПЕРИМЕНТУ ПО ВПРОВАДЖЕННЮ МОДЕЛІ ФОРМУВАННЯ ГОТОВНОСТІ МАЙБУТНІХ ОФІЦЕРІВ НАЦІОНАЛЬНОЇ ГВАРДІЇ УКРАЇНИ ДО ВИКОНАННЯ ЗАВДАНЬ ЗА ПРИЗНАЧЕННЯМ
}

\author{
Хацаюк Олександр Володимирович \\ заслужений тренер України, суддя НК з боротьби самбо \\ заступник начальника кафедри фізичної підготовки та спорту \\ Національна академія Національної гвардії України
}

Курок Олександр Іванович доктор історичних наук, професор ректор, професор кафедри дошкільної педагогіки і психології Глухівський національний педагогічний університет імені Олександра Довженка УKPAÏHA

Високий рівень бойової готовності військовослужбовців, виконання ними службово-бойових завдань за призначенням залежить від індивідуального рівня їх професійної підготовленості. Вона забезпечується постійним процесом навчання та виховання, який організовується із урахуванням вимог керівних документів, бойового досвіду, дотримання дидактичних принципів навчання та врахування вимог сьогодення. Тому визначення сучасних моделей професійної підготовки військовослужбовців із урахуванням вище зазначеного являється приорітетним напрямом наукових досліджень [1]. Використання новітніх педагогічних технологій (методик) із акцентованим впливом сучасних технічних засобів навчання під час практичних занять зі спеціальної фрізичної підготовки (СФП) та інших форм фізичної підготовки 3 курсантами Національної академії Національної гвардії України (НАНГУ) під час їх професійного становлення - забезпечує набуття ними необхідного ступеня готовності до виконання завдань за призначенням та $€$ актуальним напрямком наукових досліджень [2].

Мета дослідження - розробити модель формування готовності майбутніх офріцерів Національної гвардії України (НГУ) до виконання завдань за призначенням засобами спеціальної фізичної підготовки у вищих військових навчальних закладах (BВН3) та провести аналіз результатів педагогічного експерименту щодо її впровадження.

Розроблена нами змістово-функціональна модель формування готовності майбутніх офріцерів НГУ до виконання завдань за призначенням засобами СФП у ВВН3 містить: цільовий, організаційно-змістовий та результативно-оцінний блоки. 3 метою визначення ефективності розробленої вище зазначеної змістово-функціональної моделі проведено педагогічний експеримент (20162019 р.р.), у якому прийняли участь курсанти чоловічої статті командноштабного фракультету НАНГУ (n=121, вік досліджуваних 19-22 роки). Експериментальну роботу було запроваджено у двох групах: контрольній групі $(К г, n=60)$ та експериментальній групі $(E г, n=61)$. Під час педагогічного 
експерименту досліджувані курсанти Кг використовували традиційну методику розвитку та удосконалення необхідних військово-прикладних навичок (необхідних фрізичних якостей) спрямованих на підвищення готовності до виконання завдань за призначенням передбачених робочою програмою навчальної дисципліни «СФП» (цілеспрямований вплив на групи не здійснювався).

В Ег були створені передумови для впровадження змістово-функціональної моделі формування готовності майбутніх офіцерів НГУ до виконання завдань за призначенням засобами СФП у ВВНЗ (НАНГУ) із акцентованим використанням сучасних технічних засобів навчання. Багаторазове та систематичне відпрацювання спеціальних вправ та прийомів рукопашного бою в умовах отримання цілеспрямованої комплексної термінової інформації про основні параметри військово-прикладних рухів дозволило курсантам Ег підвищити рівень індивідуальної спеціальної фізичної підготовленості.

Висновки. За результатами проведених досліджень запропоновано змістово-функціональну модель формування готовності майбутніх офріцерів НГУ до виконання завдань за призначенням. У вище зазначеній змістовофункціональній моделі інтегровано: цільовий блок (мета, завдання, підходи, компоненти готовності, педагогічні умови), організаційно-змістовий блок (навчально-методичне забезпечення, інтерактивні методи навчання, кадрове забезпечення), результативно-оцінний блок (критерії, кваліфікаційні рівні (ступені), методики, методи, засоби, способи форми).

Аналізуючи результати отримані під час педагогічного експерименту, встановлено, що всі умови проведення експерименту були витримані. Експериментальна робота позитивно вплинула на підвищення рівня спеціальної фізичної підготовленості і готовності військовослужбовців до виконання завдань за призначенням. Зазначено, що ці зміни більшою мірою відбулися у курсантів Ег у порівняні з Кг, і ці зміни є статистично достовірними.

Слід зауважити, що незадовільний рівень спеціальної фрізичної підготовленості у курсантів, як Ег, так і Кг не помічено. Достовірність отриманих результатів підтверджена методами перевірки за допомогою критерію $X^{2}$.

Отже, мета розробки та впровадження змістово-функціональної моделі формування готовності майбутніх офріцерів НГУ до виконання завдань за призначенням засобами СФП у ВВНЗ досягнута.

\section{Список використаних джерел:}

1. Хацаюк, О. В., Гаркавий, О. А., Стаднік, А. В. \& Ананченко, К. В. (2018). Організація фрізичної підготовки у навчальних закладах НГУ. Харків: НАНГУ.

2. Хацаюк, О. В. \& Каратаєва, Д. О. (2008). Удосконалення техніки рукопашного бою правоохоронців МВС України із використанням сучасних технічних засобів навчання. (Шифрр «Модель - РБ», номер державної реєстрації 0108U007536). Наук. Дослід. Роб. Харків: АВB MBCУ. 


\title{
СТРУКТУРА МОТИВАЦІЙНОЇ СФЕРИ ЛІНГВОСАМООСВІТИ МАЙБУТНІХ УЧИТЕЛІВ ІНОЗЕМНИХ МОВ
}

\author{
Шумський Олександр Леонідович \\ Запорізький національний університет
}

УКРАÏHA

У сучасному світі, що стрімко розвивається, зростає роль самоосвіти, стаючи пріоритетом у становленні особистості. Для вчителя іноземних мов цей процес включає, перш за все, постійну роботу з підтримання та підвищення рівня володіння мовою, що вивчається, шляхом лінгвістичної самоосвіти через збагачення іншомовних знань і розвиток мовленнєвих навичок та вмінь, які, за відсутності постійної іншомовної практики, мають тенденцію до деавтоматизації. Більшість учених дотримуються одностайної думки про те, що мотивація - це один 3 ключових чинників, що впливають на темп і успішність вивчення іноземної мови. Саме мотивація забезпечує первісний стимул до вивчення іноземної мови, а в подальшому виступає рушійною силою для підтримання тривалого і часто трудомісткого самоосвітнього процесу.

Виходячи з того, що лінгвосамоосвітня діяльність студентів-майбутніх учителів іноземних мов, маючи різні джерела стимулювання її активності, $€$ полімотивованою, її мотиваційну основу, на наш погляд, мають складати групи мотивів, обумовлені специфікою та особливостями означеної діяльності, а саме: мотиви самоосвіти, соціальні мотиви, мотиви досягнення. До групи мотивів самоосвіти ми відносимо пізнавальні та лінгвоавтодидактичні мотиви. На наш погляд, доцільним $\epsilon$, в першу чергу, звернути увагу на пізнавальні мотиви, які в контексті лінгвосамоосвіти полягають в орієнтації на оволодіння новими іншомовними знаннями та закономірностями їх використання, в розумінні не лише необхідності їх засвоєння, але й у прагненні їх розширення, поглиблення і систематизації 3 метою як розширення кругозору, так і використання в професійних цілях. Лінгвоавтодидактичні мотиви, що спонукають до лінгвосамоосвітньої діяльності, спрямовані на засвоєння способів набуття іншомовних знань і прийомів саморозвитку мовленнєвих умінь та навичок, а також на самостійне вдосконалення стратегій для підтримання і підвищення рівня своїх мовних знань, умінь та навичок за рахунок неперервної лінгвосамоосвіти. Соціальні мотиви дозволяють виявити внутрішні протиріччя та визначити цілі власного саморозвитку особистості. У цю групу ми включаємо такі мотиви, як: соціально-професійний, інструментальний, (або прагматичний), мотиви, а також мотиви обов'язку, самореалізації та самоствердження. Одним 3 найбільш значущих для лінгвосамоосвітньої діяльності видів мотивації є мотивація досягнення, до якої може бути застосовано критерій успішності і яку слід розуміти як мотивацію, спрямовану на найкраще виконання діяльності, на досягнення високих результатів або, щонайменш, прагнення перевершити свої попередні показники [1].

Важливим для визначення мотиваційної сфери лінгвосамоосвіти $є$ виявлення мотиваційних орієнтацій, як комплексу спонук, об'єднаних спільною 
спрямованістю на самоосвітню діяльність. На наш погляд, найбільш релевантними задачам лінгвосамоосвітньої діяльності щодо її продуктивності $€$ мотиваційні орієнтації на процес і результат цієї діяльності [2].

Слід зазначити, що в процесі лінгвосамоосвітньої діяльності відбувається розширення спектру мотивів та зміни у їх співвідношенні в мотиваційній сфері особистості студента. Зокрема, модифікується ієрархія мотивів та підвищується ступінь їх усвідомленості.

\section{Список використаних джерел:}

1. Маркова, А. К. (1996). Психология профрессионализма. Москва: Знание.

2. Dweck, C. S. (1999). Self-theories: their role in motivation, personality, and development. Philadelphia: Psychology Press, Taylor and Francis Group.

DOI 10.36074/25.10.2019.v2.20

\section{О ФОРМИРОВАНИИ КОММУНИКАТИВНО-РЕЧЕВЫХ УМЕНИЙ УЧЕНИКОВ НАЧАЛЬНЫХ КЛАССОВ}

Сокаль Марія Анатоліївна

канд. фрілолог. наук, доцент, завідувач кафедри слов'янського мовознавства ДЗ «Південноукраїнський національний педагогічний університет імені К. Д. Ушинського

УКРАÏHA

Одна из важнейших задач современной школы - формирование и развитие коммуникативных умений учащихся. Младший школьный возраст оптимальный период наиболее активного обучения социальному поведению, искусству общения в детском коллективе и со взрослыми, т. е. усвоения коммуникативных, в том числе речевых умений. Речевой аспект в обучении родному языку всегда признавался прогрессивной методикой (Ф. И. Буслаев, К. Д. Ушинский, И. И. Срезневский и др.), но пути его реализации во многом оставались нерешенными. Новое в современных приемах обучения речевому общению обусловлено достижениями в области лингвистики, психологии, лингводидактики.

Необходимость формирования коммуникативной компетентности учеников В структуре языкового компонента начального образования признана приоритетной и получила законодательное закрепление. Однако, как показывают лингводидактические исследования, обобщающие опыт работы в начальной школе, проблема формирования речевого общения далека от разрешения. Необходимы рациональные методики, которые базировались бы на принципе активной коммуникации. Недостает системы упражнений и заданий для повышения коммуникативной культуры; слабо отражены интегративные и межпредметные связи, достижения новых отраслей лингвистической науки, занимающихся изучением коммуникации (психолингвистики, в том числе нейролингвистики, прагматики, 
коммуникативной лингвистики и др.); не в полной мере осуществляется дидактическая идея «от практики к теории и опять к практике», «от простого к сложному»; работа по усовершенствованию коммуникативно-речевых умений проводится эпизодически, в ней не всегда реализуется личностноориентированный подход и т. д. В то же время овладение коммуникативноречевыми навыками, позволяющими ясно и убедительно выражать свои мысли, отстаивать свою точку зрения, понимать собеседника, налаживать контакты и под. - необходимое условие социализации ребёнка. Это требование времени предполагает совершенствование преподавания языка, в том числе и в начальной школе.

Для успешного решения вопросов формирования коммуникативноречевой активности младшеклассников, учителю важно отчетливо представлять, во-первых, содержание работы по развитию коммуникативных способностей учеников, т.е. то, какими знаниями и умениями следует их вооружить; во-вторых - способы организации обучения: виды соответствующих упражнений, приёмы работы и т. д.

Изучение языковой теории все шире входит в практику обучения в начальной школе. Появляются элементы семантики, теории текста, рассматривается необходимость введения раздела «Словообразование» и др. Методисты полагают, что ребенок станет работать эффективней, если будет иметь общее представление о речи и речевой деятельности. В 6-7летнем возрасте, уже обладая речевым опытом, дети в состоянии обобщить его на элементарном уровне под руководством учителя. «Изучение знаний о языке вносит определенную структуризацию в рече-языковую компетенцию каждого ребенка (понятно в разной мере), обеспечивает развитие не существующих прежде языковых способностей, поднимает речь к высшим уровням её проявления. Однако, чтобы обеспечить такие сдвиги и достичь развитости речеязыковой компетентности детей нужно найти варианты решения этой проблемы»[1].

К примеру, могут быть обобщены представления детей о речевом действии (акте). Речевой акт предполагает наличие того, кто обращается с речью - «отправителя», и того, кому адресуется речь - «получателя». Опираясь на эти представления, достаточно немного углубиться в анализ реальных речевых ситуаций (в одних случаях собеседники рядом, тогда один их них говорит, а другой слушает, а в других - они далеко друг от друга, тогда один пишет, а другой читает), как становятся доступными понятия «устная» и «письменная речь». Именно эти понятия делают оправданным, мотивированным для детей особое выделение задач обучения грамоте: говорить и слушать они уже в какой-то мере умеют, а читать и писать ещё нет. Так формирование навыка чтения, графических и орфографических навыков оказывается органично включённым в решение более широкой задачи, связанной с обучением речевой деятельности. «Коммуникативная направленность заданий обеспечит развитие собственно речевых умений: ориентацию в условиях и содержании высказывания, форме его изложения, группировку собранного материала, определение последовательности частей текста, выделение слов, важных для высказывания, совершенствование собственного текста» [2]. 
112 - Scientific discoveries: projects, strategies and development $\bullet$ Volume 2

Обобщению, доступному младшекласснику, поддаются процессы порождения и восприятия внешней речи.

Для анализа и синтезирования детьми процесса порождения речевого высказывания можно предложить им ряд проблемных заданий. Например, ученик нарушил дисциплину и теперь его родителей вызывают в школу. Необходимо сообщить об этом дома. Сделать это, как известно, нелегко, и ученикам предлагается помочь герою. Вот приходит он из школы и видится по очереди с мамой, старшим братом, бабушкой, любимой собакой. В чем же ему придётся признаться? («Родителей вызывают в школу», - отвечают дети). Кому он будет объяснять это долго, а кому - коротко? Кому пожалуется на учителя, а у кого попросит прощения, кому даст обещание исправиться? Кому и вовсе ничего не скажет, а просто тяжело вздохнёт? и т. д. Получив разные варианты признания (можно сделать их аудиозапись), анализируем с учениками, как рождались высказывания мальчика. Вначале ему нужно было сказать правду родным (это мотив речи). Какую правду? «Родителей вызывают в школу» - это смысл его признания, назовём его стержнем. Затем появились сами признания. Они разные (зависят от особенностей адресата). Но что было в каждом из них? Какое главное сообщение? («То, что является стержнем», - отвечают дети). Значит, модель порождения речевого высказывания будет такой: мотив - смысл (стержень) - варианты. Учащиеся убедились, что все варианты высказывания идут от стержня. Предлагаем ученикам визуализировать данную модель (возможные варианты: солнце и лучи; стебель, головка ромашки и ее лепестки; брызги от камня, упавшего в воду; дерево с толстыми, основательными ветвями и тоненькими, ранимыми молодыми побегами и под.).

Эту модель, отражающую основные этапы порождения высказывания, можно использовать как опору для построения как одной фразы, так и различных текстов. Порядок работы с моделью следующий: (1) побуждение к речевой деятельности при помощи естественных или искусственных ситуаций, заданий учителя; (2) фиксирование основного смысла будущего высказывания - определение «стержня»; (3) составление речевого высказывания с учётом факторов его вариантности.

Надежной основой обучения речевой деятельности является применение коммуникативных заданий с игровыми моментами, к которым можно отнести ролевые игры, упражнения с элементами театрализации (диалоги, инсценировки, основанные на исполнение различных ролей в воображаемых, но обязательно приближенных к реальному общению ситуациях). Использование таких коммуникативных упражнений помогает ученику увидеть взаимоотношения людей через личный опыт, успешно стимулирует его речетворчество. Искусственные речевые ситуации, ориентированные на реальную коммуникацию, позволяет преодолеть формальный подход к обучению. Ситуативные упражнения способствуют укреплению межличностных контактов, реализации продуктивного интерактивного общения между членами классного коллектива. Учитель, продумывая содержание учебных речевые ситуаций, имеет прекрасную возможность индивидуализировать учебный процесс, ориентируясь на уровень коммуникативных умений и особенности личности говорящего. 
В целом, «как спонтанное, так и управляемое в процессе речевой работы приобретение ребёнком рече-языковой компетенции... необходимо не только развивать далее, но и обязательно использовать во время выделения и осознания детьми существенных признаков языковых явлений» [1]. Вводя элементарные речеведческие понятия, мы помогаем ученикам осмыслить их речевую практику, уяснить значение речи в жизни каждого человека и постепенно совершенствовать определённые умения, необходимые в общении.

\title{
Список використаних джерел:
}

1. Калмикова, Л. О. (2017). Перспективність і наступність в навчанні мови й розвитку мовлення дітей дошкільного $i$ молодшого шкільного віку: психолінгвістичний $i$ лінгвометодичний виміри. Київ: Видавничий Дім «Слово».

2. Нечаєва, Л.ІІ\& Гоцуляк, Д.І. (2011). Дидактичні матеріали для розвитку комунікативних умінь молодших школярів. Тернопіль: Підручники і посібники.

\section{ОСОБЛИВОСТІ АНСАМБЛЕВОЇ ФОРМИ ВИКОНАВСТВА}

\author{
Шумська Ольга Олександрівна \\ Харківська гуманітарно-педагогічна академія \\ Третецька Марія Володимирівна \\ Харківська гуманітарно-педагогічна академія
}

УКРАÏHA

Ансамблеве виконавство $€$ важливою складовою процесу виховання музиканта. Гра в ансамблі, як правило, сприймається студентами з великою захопленістю і натхненням, що пов'язано зі специфікою цього виду виконавства - музичний твір озвучується в спільній творчості кількох учасників. Навчальна ансамблева діяльність сприяє розвитку необхідних виконавських якостей у музиканта, адже передбачає не тільки ґрунтовне володіння власною партією, але й володіння специфічною ансамблевою виконавською технікою, об'єднаною в конкретних художньо-звукових образах і художньому трактуванні музичного твору [1].

Оволодіння практичними основами ансамблевого виконавства неможливо без вироблення найважливішого ансамблевого досвіду - синхронності звучання. Синхронність $є$ результатом найважливіших якостей ансамблю єдиного розуміння і відчування партнерами темпу і ритмічного пульсу» [2, с. 129]. Отже, в ансамблі існує потреба в координації виконавських намірів учасників, об'єднання їх загальним задумом.

Гра в ансамблі вимагає від кожного учасника серйозного перегляду звичних уявлень про силу і тембр звучання кожної партії і співвіднесення їх, при необхідності, з тембрами оркестру. Підкреслимо, що гра в ансамблі краще розвиває такі навички студента: дисциплінує ритміку (вчить рахувати паузи, «порожні» такти, вчасно вступати; допомагає подолати такі недоліки, як невміння тримати один темп, млявий або занадто карбованим ритм; розвиває 
тонкість «ритмічного слуху». Тому в процесі навчальних ансамблевих занять студенти привчаються до узгодження виконавських намірів між учасниками ансамблю: досягнення синхронності і правильного співвідношення звучання партій, дотримання загального темпу і метроритму, спільності динамічних нюансів і штрихів, синхронності фразування і педалізації.

У процесі ансамблевих занять відбувається більш інтенсивний розвиток музичного слуху, почуття ритму, музичної пам'яті і рухово-моторних навичок. Так, виконання в ансамблі допомагає студентам краще сприймати гармонійну вертикаль і складні гармонії, яскравіше використовувати окремі елементи звукових конструкцій за рахунок різних динамічних нюансів, штрихів і тембрових фарб. Виконуючи свою партію в ансамблі, виконавець знаходиться в суворих метроритмічних рамках, що сприяє виробленню необхідного почуття метричної пульсації і навичок дотримання певного темпоритму. Дуже важливо, що гра в ансамблі навчає слухати партнера. Отже, ансамблісти, спілкуючись у різних музичних ситуаціях, повинні вміти співвідносити і штрихи, і особливості фразування, і загальний динамічний план, що визначаються їх загальним виконавським задумом.

Таким чином, навчання в класі ансамблевого виконавства - одна з дуже важливих складових процесу професійної підготовки майбутнього педагогамузиканта. Оскільки отримані в процесі навчання музично-слуховий досвід, а також досвід колективної творчості мають практичне значення не тільки для успішного оволодіння виконавською технікою ансамблевої гри, але й дозволяють майбутньому педагогу-музиканту набути навичок, актуальних для сучасної музично-педагогічної діяльності.

\section{Список використаних джерел:}

1. Матвійчук, Л.Д.(2008). Методичні основи ансамблевого виконавства. Київ: Національна музична академія України імені П. І. Чайковського.

2. Пляченко, Т. М. (2009). Методика роботи з музично-інструментальними колективами. Кіровоград: Імекс-лТД.

\section{ПЕДАГОГІЧНІ УМОВИ ФОРМУВАННЯ БАЗОВИХ КОМПЕТЕНТНОСТЕЙ МАЙБУТНІХ СОЦІАЛЬНИХ ПРАЦІВНИКІВ У ПРОЦЕСІ ФАХОВОЇ ПІДГОТОВКИ}

Стрельбицька Світлана Михайлівна викладач кафедри психіатрії, наркології та психології Одеський національний медичний університет УКРӒ̈HA

Динамізм сучасного суспільства в соціально-економічній, політичній, культурно-ціннісній сферах змінив багато життєвих пріоритетів. Це знайшло відображення в зростаючих вимогах до підготовки майбутніх випускників ЗВО, їх конкурентоздатності в умовах сучасного нестабільного ринку праці. У зв'язку з чим, актуальними стали освітні тенденції засновані на компетентнісному 
підході, як одному з напрямів модернізації професійної освіти. Відтак, стратегічним завданням вищої освіти України стала підготовка компетентного фахівця, здатного та готового ефективно використовувати на практиці отримані у ЗВО знання, уміння та навички, діяти за межами навчальних ситуацій, вирішувати типові та проблемні завдання, які виникають в майбутній професійній діяльності. Формування базових компетентностей майбутніх фахівців, зокрема соціальних працівників відноситься до числа найбільш актуальних проблем підготовки сучасного фахівця.

Ефективність формування базових компетентностей майбутніх соціальних працівників обумовлена обов'язковою наявністю педагогічних умов. Перш ніж визначити педагогічні умови для успішного формування базових компетентностей майбутніх соціальних працівників, розглянемо тлумачення категорії «умова» в науковій літературі. Згідно із визначенням, у енциклопедичних словниках, поняття «умова» розглядається як категорія, що виражає відношення щодо предмета до оточуючих його явищ, без яких він існувати не може. Сам предмет виступає як щось зумовлене, а умова як зовнішнє предмета різноманіття об'єктивного світу [6]. Сукупність певних умов конкретного предмета формує середовище його існування, завдяки впливу якого, забезпечується реалізація закономірних зв'язків і відношень.

Учені окремо виділяють ще й поняття «педагогічні умови», спрямовані на вирішення проблем, які виникають при здійсненні цілісного педагогічного процесу. Визначення умов набуває «педагогічного» забарвлення в дослідженнях різних учених (В. Бауэр, М. Зверева, Б. Куприянов, З. Курлянд), знайшовши своє відображення в численних трактуваннях терміна «педагогічні умови». Зокрема, при розгляді поняття «педагогічні умови» в дослідженнях зустрічаються такі його тлумачення: «змістова характеристика одного 3 компонентів педагогічної системи, в якості, якого виступають зміст, організаційні форми, засоби навчання та характер взаємин між тими, хто навчається» [3]; «становище, в якому компоненти освітнього процесу представлено в найкращій взаємодії, що дає викладачеві змогу плідно працювати, керувати освітнім процесом, а тим, хто навчається, успішно працювати» [1]; «планомірна діяльність, яка дозволяє уточнити закономірності освітнього процесу і перевірити ефективність цього процесу» [4].

Ґрунтуючись на означених підходах, вважаємо, що педагогічна умова - це обставина, яка зумовлює чи від якої залежить цілісний продуктивний процес підготовки до формування базових компетентностей майбутніх соціальних працівників. В свою чергу, педагогічні умови формування базових компетентностей майбутніх соціальних працівників - це сукупність обставин і засобів, які сприяють організації освітньо-виховного процесу з урахуванням потреб, інтересів, можливостей майбутніх фахівців, результатом якого будуть сформовані базові компетентності в процесі фахової підготовки.

Виділяючи педагогічні умови, спрямовані на формування базових компетентностей майбутніх соціальних працівників у процесі фахової підготовки, виходили з таких позицій: мету і зміст формування базових компетентностей студентів у процесі вивчення фахових дисциплін необхідно визначати через зміст і характер майбутньої професійної діяльності; наявність потенціалу спеціальних дисциплін для інтегрування професійної підготовки 
майбутніх соціальних працівників; важливість позитивної мотивації для формування базових компетентностей майбутніх фахівців соціальної сфери. Мета з якою виділяються педагогічні умови, сутнісні характеристики запланованого результату і особливості середовища, в якому здійснюється процес досягнення мети, в свою чергу, визначають вибір конкретних педагогічних умов.

Першою педагогічною умовою формування базових компетентностей майбутніх соціальних працівників є стимулювання позитивної мотивації до професійної діяльності майбутніх соціальних працівників, яка передбачає формування усталеного позитивного мотиву та спрямованості студентів на оволодіння базовими компетентностями, зацікавленість і мотивацію досягнення результату, й базується на їхній здатності до виконання професійної діяльності. Зауважимо, що професійна здатність майбутніх фахівців до конкретної професійної діяльності визначається не тільки рівнем розвитку здібностей, але і рядом інших особистісних властивостей, характером мотиваційної сфери - змістом мотивів, інтересів і ціннісних орієнтацій і спрямованістю і ступенем активності. Мотивація являє собою ті внутрішні сили організму, які спонукають випускників до майбутньої професійної діяльності, скеровані на задоволення потреб суб'єкта, викликані внутрішніми і зовнішніми умовами та визначають спрямованість діяльності. Спрямованість і сила мотивації визначають здібності і рівень творчої особистості, окреслюють траєкторію її активності, тим самим визначають розвиток майбутнього фахівця в професійному відношенні, ступінь його внеску в колективний результат і якість майбутньої діяльності. Більш того, мотивація $€$ процесом формування у майбутніх фахівців необхідних позитивних стимулів, які $€$ зовнішнім спонуканням до професійної діяльності, що розвивається на основі усвідомлення своїх особистісних потреб, так і потреб інших людей. При стимулюванні позитивної мотивації у випускників з'являється можливість не тільки задовольняти свої власні потреби, але й одночасно досягати мети майбутньої професії, яку він здобуває у ЗВО.

Стимулювання завжди $є$ ефективним методом впливу на студента через його мотивацію. Результатом стимулювання позитивної мотивації до професійної діяльності у майбутніх соціальних працівників виникають професійні мотиви насамперед задоволеність або незадоволеність своєю професією та самореалізація особистості у майбутній професійній діяльності. Для майбутніх соціальних працівників мотивація до досягнення максимального рівня професійної здатності й $є$ важливим чинником успішності професійної діяльності. При цьому фахова підготовка повинна бути спрямована на те, щоб природні потреби досягнення успіху та виконання поставлених завдань трансформувалися в професійну мотивацію вирішення соціальних проблем клієнта.

Другою педагогічною умовою є відображення у змісті фрахових дисциплін специфіки соціальної роботи. Зазначимо, професійна підготовка майбутніх соціальних працівників передбачає вивчення низки фахових дисциплін, спрямованих на формування їхніх базових компетентностей, а саме: «Вступ до спеціальності», «Історія та теорія соціальної роботи та допомоги», «Психологія спілкування», «Соціально-правовий захист населення», 
«Акмеологія», «Психологія здоров'я». Зокрема, «Вступ до спеціальності» служить основною науковою дисципліною, з якої починається систематичне відкриття та розуміння соціальними працівниками суті своєї майбутньої професійної діяльності, чітке уявлення свого професійного вибору, затвердження себе в якості людини, чиї головні життєві потреби, орієнтації і цінності визначаються поняттями соціальне служіння, соціальна робота й соціальна допомога. У процесі вивчення дисципліни «Історії та теорії соціальної роботи та допомоги» у студентів формується цілісне та ціннісне ставлення до історичної практики захисту й підтримки соціально незахищених верств населення, виробленої у світовому просторі, системні знання теорії, методології та технології соціальної роботи як області пізнання та практичної діяльності, спрямованої на задоволення потреб людини та забезпечення соціальних змін у суспільстві. За допомогою вивчення дисципліни «Психологія спілкування» у майбутніх соціальних працівників формуються уміння застосовувати техніки і прийоми ефективного спілкування в професійній діяльності; використовувати прийоми саморегуляції поведінки в процесі міжособистісного спілкування. Після вивчення дисципліни «Соціальноправовий захист населення» у майбутніх фрахівців з'являється система знань з соціального захисту в Україні, навичок та вмінь працювати з нормативноправовими актами, опановувати методики правового аналізу правових норм у роботі соціальних правозахисників тощо. Результатом вивчення дисципліни «Акмеологія» у майбутніх соціальних працівників формується уявлення про шляхи професійного становлення й особистісного розвитку. В результаті вивчення дисципліни «Психологія здоров'я» у майбутніх соціальних працівників з'являється система поглиблених медичних, психологічних знань і навичок для успішної професійної діяльності, профрілактики фізичного, психічного соціального здоров'я, потреби у здоровому способі життя.

Третьою педагогічною умовою в дослідженні є реалізація рефрлексійного складника підготовки соціальних працівників у процесі виробничої практики. У сучасному процесі професійної підготовки майбутніх соціальних працівників особливу роль має практичний складник освітнього процесу. Для досягнення цієї мети в освітньому процесі впроваджена виробнича практика студентів. Виробнича практика $€$ одним 3 найважливіших складників професійної підготовки майбутніх фрахівців. У сучасній педагогічній науці поняття «виробнича практика» займає одне 3 ключових місць і $€$ обов'язковим складником процесу фахової підготовки майбутніх соціальних працівників. Виробнича практика дозволяє студентам реалізувати на практиці свої сили в обраній професії, навчитись застосовувати в професійній діяльності знання, вміння та навички [5]. Саме завдяки виробничій практиці забезпечується соціалізація майбутніх соціальних працівників в професійному середовищі та формується компетентний фахівець з соціальної роботи. Більш того, будучи центральною ланкою в системі підготовки майбутніх соціальних працівників, виробнича практика допомагає студентам глибше усвідомити правильність здійснення свого професійного вибору, перевірити засвоєння теоретичних знань, умінь і навичок отриманих в процесі навчання.

Виробнича практика має істотний вплив на фрормування професійних ціннісних орієнтацій майбутніх соціальних працівників, у ході якої відбувається 
включення студентів у професійну діяльність, студенти отримують можливість самореалізуватися і самоствердитись в особистісно-значущій діяльності та відносинах, що сприяє закріпленню їхнього особистого професійного досвіду. Крім того, студенти під час практики навчаються професійній взаємодії, усвідомлюють соціальну цінність соціальної роботи, оцінюють проблемне поле майбутньої професії. Виробнича практика надає можливість соціальним працівникам осмислити майбутню професію, розвинути професійну допитливість, сформувати початковий інтерес у науково-дослідній сфері.

Осмислення соціальними працівниками майбутньої професії відбувається за допомогою професійної рефлексії, посилення якої проходить шляхом урахування саме потенціалу виробничої практики. Професійна рефлексія забезпечує майбутнього соціального працівника розумінням власного внутрішнього світу, самоорганізацією внутрішніх станів і осмисленістю професійної діяльності. Саме професійна рефлексія сприяє становленню особистості майбутнього професіонала в процесі навчання у ЗВО.

У психолого-педагогічних дослідженнях висвітлено різні підходи до розуміння професійної рефлексії. У загальному вигляді професійна рефлексія розглядається як: здатність до здійснення індивідуального творчого внеску в професію, знаходження свого індивідуального призначення в ній (О. Анісімов); співвіднесення себе, можливостей свого «Я» з тим, що вимагає обрана професія, в тому числі з наявними про неї уявленнями (Б. Вульфов,); якісна характеристика суб'єкта діяльності, що перетворює світ, носія свідомості та самосвідомості, що усвідомлює специфіку свого професійного «Я» (Н. Кузьміна); процес і результат фіксування фахівцем стану свого професійного розвитку, саморозвитку та їх причин, спрямованість свідомості на власні думки і почуття, оцінку результатів професійної діяльності (В. Орлов); процес, спрямований на усвідомлення себе як особистості й профеесіонала, усвідомлення своїх дій, поведінки, професійного іміджу (Н. Пов'якель).

Особливе значення для майбутніх соціальних працівників проблема професійної рефлексії набуває в умовах їхньої професійної взаємодії, яка передбачає центрацію на суб'єкт-суб'єктні відносини, оскільки професійна рефлексія у майбутніх соціальних працівників проявляється в процесі їхньої міжособистісної взаємодії у комунікативних відносинах [7].

Зазначимо, що професійна рефлексія майбутніх соціальних працівників це співвіднесення себе, можливостей свого «Я» з тим, чого вимагає обрана ними професія. Аналіз досліджень професійної рефлексії студентів майбутніх соціальних працівників дозволив дійти висновку про те, що рефлексія передбачає: 1) аналіз студентом освітньо-професійної діяльності; 2) осмислення діяльності на заняттях у ЗВО у штучно чи природно створених умовах; 3) усвідомлення діяльності щодо саморозвитку та самовдосконалення себе як майбутнього фахівця.

Використання рефлексії під час проходження виробничої практики - це здатність майбутніх соціальних працівників аналізувати результати своєї діяльності, встановлювати межі власної діяльності при вирішенні освітніх завдань, коригувати власні дії. Іншими словами, здатність думати про те, як я мислю, знати, що знаю, і знати, як знаю. Рефлексія в майбутній професійній діяльності містить у собі потенціал розвитку, який за певних умов дозволяє 
піднімати ії на новий рівень. Для майбутніх фрахівців соціальних працівників професійна рефлексія у професії виконує складну функцію саморегуляції, що дозволяє досліджувати ситуацію, проектувати і оцінювати професійну діяльність до і після її здійснення, закріплювати успішні дії для реалізації конкретної мети, здійснювати корекцію невдалих дій і здійснювати їх саморозвиток.

Науковий пошук та вивчення сучасного стану сформованості базових компетентностей майбутніх соціальних працівників у освітньому процесі закладу вищої освіти, сприяли висновку, що для фрормування базових компетентностей майбутніх соціальних працівників у процесі фахової підготовки необхідно реалізувати наступні педагогічні умови: стимулювання позитивної мотивації до професійної діяльності майбутніх соціальних працівників; відображення у змісті фахових дисциплін специфіки соціальної роботи; реалізація рефлексійного складника підготовки соціальних працівників у процесі виробничої практики.

Проведене дослідження не вичерпує всіх аспектів окресленої проблеми і тому, відповідно до сучасних тенденцій розвитку системи вищої освіти, потребує в майбутньому подальших наукових розвідок

\section{Список використаних джерел:}

1. Бауэр, В. В. Педагогические условия самореализации будущего учителя в процессе педагогической практики. Проблемы и перспективы развития образования: материалы междунар. науч. конф., 2011, (c. 40-41). Пермь: Меркурий.

2. Вербицкий, А. А. \& Ильязова, М. Д. (2011). Инварианты професссионализма: проблемы формирования. М.: Логос.

3. Зверева, М. В. (1987). О понятии «дидактические условия». Новые исследования в педагогических науках. Педагогика, (1), 29-32.

4. Сластенин, В. А. (1993). Социальный педагог и социальный работник: личность и профессия. Теория и практика социальной работы: отечественный и зарубежный опыт, (с. 165-175). Москва-Тула: СОЮЗ-Просвещение.

5. Стрельбицька, С. М. Виробнича практика як умова формування базових компетентностей майбутніх соціальних працівників. В Корнещук, В. В. (ред.). Актуальні дослідження в соціальній сфрері: матеріали одинадиятої міжнародної науково-практичної конфреренції (м. Одеса, 17 травня 2018 р.), (с. 194-196). Одеса: ФОП Бондаренко М. О..

6. Фролов, И. Т. (ред.). (1981). Философский словарь. М.: Политиздат.

7. Strelbitskaya, S. M. Professional reflexion as a necessary condition for formation future social works specialists' competence at the university. Modern Tendencies in the Pedagogical Science of Ukraine and Israel: the way to integration: VII International Conference, (№7, p. 344-349). Israel: Ariel University Ariel. 


\title{
ПИТАННЯ ПРОФІЛЬНОГО НАВЧАННЯ У 90-ТИХ РОКАХ ХХ СТОЛІТТЯ
}

\author{
Загородня Алла Анатоліївна \\ канд. пед. наук, доцент, провідний науковий співробітник \\ відділу історії та фрілософії освіти \\ Інститут педагогіки НАПН України
}

УКРАЇ̈А

Впровадження профільного навчання у старших класах середньої школи $є$ одним із пріоритетних напрямів оновлення змісту сучасної освіти, серед ключових завдань якого: підвищення якості сучасної освіти, гуманізація навчання, задоволення освітніх потреб, самоактуалізація особистості, утвердження унікальності, неповторності і самоцінності індивідуальності школяра, що дозволяє за рахунок зміни у структурі, змісті й організації освітнього процесу враховувати інтереси та здібності учнів, створювати умови для їхньої освіти відповідно до професійних інтересів та життєвих планів. Різноманітні аспекти профілізації середньої освіти у старших класах середньої школи вивчали українські та зарубіжні науковці, а саме: висвітленням загальних теоретичних питань профілізації навчання опікувалися О. Бугайов, С. Броневщук, М. Бурда, Г. Бунтовська, М. Гузик, О. Корсакова, С. Логачевська, Х. Лійметс, Н. Огурцов, А. Пінський, Л. Рожина, П. Сікорський, B. Фірсов, Н. Шиян, R. Aldrich, J.Bastian, A.Combe, L. Cremin, M. Curtis, D. Dean, P. Gordon, H.Gudjons, T. O'Brien, G. Walford та ін.; проблемі становлення та розвитку профрільної школи присвячені праці Л. Березівської, Н. Бібік, Л. Бондар, Н. Дічек, В. Кизенка, О. Локшиної, І. Лікарчук, В. Лугового, Ю. Мальованого, В. Огнев'юка, О. Сухомлинської та ін.; проблеми загальнопедагогічної та загальнодидактичної специфіки профрільного навчання знайшли відображення у дослідженнях С. Вольянської, І. Лікарчука, М. Сметанського та ін.

Основними нормативно-правовими документами в яких висвітлено стратегічні завдання реформування системи освіти та сфрери загальної середньої освіти є: Державна національна програма «Освіта. Україна XXI століття» (1993); Закони України: «Про освіту» (1991), «Про загальну середню освіту» (1999); «Концепція загальної середньої освіти» (12-річна школа) (2001); «Концепція профільного навчання в старшій школі» (2003), Галузева Програма впровадження профільного навчання на 2008-2010 рр. (2008) [1].

Профрільне навчання - це вид диференційованого навчання, який передбачає врахування освітніх потреб, нахилів та здібностей учнів і створення умов для навчання старшокласників відповідно до їхнього професійного самовизначення, що забезпечується за рахунок змін у цілях, змісті та структурі організації навчання [1]. У «Національній доктрині розвитку освіти в Україні на 2012-2021 рр.» профілізація трактується як один із шляхів забезпечення рівного доступу дітей до освіти [2]. 
Мета профрільного навчання полягає у забезпеченні рівних можливостей для доступу учнівської молоді до здобуття загальноосвітньої профрільної та початкової допрофесійної підготовки;

гарантування неперервної освіти впродовж усього життя; виховання особистості, здатної до самореалізації, професійного зростання й мобільності в умовах рефрормування сучасного суспільства [3].

\section{Список використаних джерел:}

1. Загородня, А. А. (2018). Диференціація змісту навчання у старшій школі як ефективна умова реалізації особистісно-орієнтованої парадигми освіти. Педагогічна освіта: теорія $i$ практика, (25), 59-65.

2. Положення про середній загальноосвітній навчально-виховний заклад. (1993). Освіта, (29), 8-9.

3. Концепція становлення мережі середніх закладів освіти для розвитку творчої обдарованості. (1996). Інформаційний збірник Міністерства освіти, (17-18), 53-64.

\section{ПІДГОТОВКА ВЧИТЕЛЯ АНГЛІЙСЬКОЇ МОВИ ДО НАВЧАННЯ ДІТЕЙ ДОШКІЛЬНОГО ВІКУ}

Педагогічний інститут Кӥвського університету Прочук Віра Андріївна Науковий керівник: Кошарна Наталія Володимирівна канд. пед. наук

Педагогічний інститут Київського університету імені Бориса Грінченка УКРAÏHA

Сучасна освітня парадигма вимагає від підростаючого покоління володіння іноземною мовою на такому рівні, щоб нею можна було не тільки спілкуватися на побутовому та освітньому рівні, а й встановлювати ділові та наукові контакти $з$ представниками інших країн. Незважаючи на те, що сьогодні ми маємо розмаїття методик інтенсивного навчання розмовної та ділової мови, переважна більшість мовців потребують декілька років підготовки задля вільного спілкування іноземною мовою. На основі теоретичного аналізу робіт зарубіжних і вітчизняних вчених доведено, що вивчення іноземних мов у ранньому віці спрямоване на розвиток мовлення дітей дошкільного віку в найбільш сприятливий для них період. Саме тому постає питання у якісній підготовці вчителя англійської мови для навчання дітей дошкільного віку.

Специфічною ланкою іншомовної освіти $€$ дошкільна. Специфріка дошкільної ланки обумовлюється віковими особливостями дітей, найхарактернішими з яких $є$ не сформованість довільної уваги та пам'яті і схильність до гри, та визначається необов'язковим характером навчання дітей іноземної мови, так і [4].

У процесі підготовки до роботи з дітьми дошкільного віку майбутні вчителі англійської мови повинні оволодіти технологіями формування кожного виду іншомовної комунікації у молодших школярів, оскільки вчитель англійської 
мови повинен чітко усвідомлювати перехід від дошкільної до початкової ланки освіти.

Формування методичної компетенції здійснюється в загальній системі формування у студентів професійної компетенції вчителя англійської мови для роботи у закладах дошкільної освіти.

Як визначено у словнику методичних термінів, професійна компетенція вчителя іноземної мови включає мовну компетенцію (дає уявлення про знання системи іноземної мови та про вміння нею користуватися для розуміння мовлення інших людей і для вираження власних думок в усній/письмовій формі, а також для аналізу мовлення учнів з точки зору його відповідності нормам виучуваної мови), мовленнєву і комунікативну компетенцій (здібність до використання іноземної мови як засобу спілкування в різних сферах і ситуаціях) та методичну компетенцію (здібність користуватися іноземною мовою у професійних цілях, навчаючи мови) [1].

У процесі підготовки до навчання дітей іноземної мови студентам необхідно вивчити прийоми проведення спокійних і рухливих ігор на заняттях з англійської мови [3], зокрема, фізкультхвилинок, постановок театральних вистав, розучування віршиків, пісень, малювання коміксів, знання дитячих кінострічок та мультфільмів. Вдалими кроками в цьому напрямку можуть слугувати сценарії до відеокурсів англійської мови для дітей: «Muzzy in Gondoland», «Muzzy comes back» (BBC English), що в значній мірі розвивають комунікативну компетентність дитини на доступному рівні, збірник пісень на англійській мові (відео з музичним супроводом) «Mother Goose» [2].

Майбутні вчителі англійської мови повинні проводити заняття цікаво, доступно, енергійно, вміти «тримати» в полі зору всю групу дітей і кожну дитину окремо, вміти переключати увагу дітей з одного виду діяльності на іншу, чітко планувати хід заняття.

Таким чином, методична компетенція $€$ обов'язковим компонентом професійної компетентності вчителя іноземної мови до роботи в закладах дошкільної освіти. У визначенні поняття «методична компетенція вчителя іноземної мови» мають бути відображенні не лише знання, навички, вміння і здібності студента у володінні ним усіма видами іншомовної комунікативної компетентності, але й методичні знання, навички, вміння і здібності щодо навчання іноземної мови дітей дошкільного віку цих же видів іншомовної комунікативної компетенції. Цільова підготовка вчителів англійської мови для роботи у системі дошкільної освіти - перспективна, оскільки у наш час дошкільна іншомовна освіта вийшла за межі експериментального навчання i стає ознакою сьогодення. Дошкільну іншомовну освіту здобуває все більше дітей. На сьогодні така підготовка здійснюється у різноманітних формах - як індивідуальних (у родинах), так і колективних (у закладах дошкільної освіти, гуртках іноземної мови, різних освітніх закладах тощо).

\section{Список використаних джерел:}

1. Азимов, Э. Г. \& Щукин, А. Н. (1999). Словарь методических терминов. СПб: Златоуст.

2. Казачінер, О. С. (2014). Усі заняття з англійської мови в ДНЗ (за базовим компонентом дошкільної освіти). Харків: Вид. група «Основа».

3. Лобода, О.В.(2013). Методика навчання англійської мови дітей дошкільного віку. К.: Київ ун-т ім. Б. Грінченка.

4. Шкваріна, Т. М. (2005). Науково-методичний комплекс з англійської мови для дошкільної освіти. Іноземні мови. 


\section{ПІДГОТОВКА ВЧИТЕЛЯ ДО РЕАЛІЗАЦІЇ КОМПЕТЕНТНІСНО ОРІЄНТОВАНОГО НАВЧАННЯ: СТАН ТА ПЕРСПЕКТИВИ}

Левченко Фессалоніка Григорівна

канд. пед. наук, доцент, старший науковий співробітник

відділу профільного навчання

Інститут педагогіки НАПН України

УКРАЇНA

В узагальненнях Міжнародних порівняльних досліджень якості освіти TIMSS та PISA йдеться про невідповідність вітчизняної системи освіти світовим стандартам. Це насамперед пов'язано з тим, що в зарубіжних країнах у процесі навчання більше уваги приділяється практичному значенню вивченого, застосуванню набутих знань та вмінь у нестандартних, змінених умовах. Це свідчить про необхідність формування особистості нового типу, здатної розв'язувати проблеми, встановлювати міжпредметні і внутрішньопредметні зв'язки. Отже, компетентнісний підхід, що прийшов на зміну так званій ЗУНівській парадигмі, - це спроба привести у відповідність результати роботи масової школи до потреб ринку праці, стандартів вітчизняної системи освіти і світових вимог.

У Проекті Закону України «Про освіту» зазначено, що метою повної загальної середньої освіти $є$ різнобічний розвиток, виховання і соціалізація особистості, яка усвідомлює себе громадянином України, здатна до життя в суспільстві та цивілізованої взаємодії 3 природою, має прагнення до самовдосконалення і навчання впродовж життя, готова до свідомого життєвого вибору та самореалізації, трудової діяльності та громадянської активності [1].

Щоб виконати ці вимоги, потрібно не тільки оновити зміст і технології освіти, але перш за все, підготувати вчителя, здатного вирішувати ці складні соціально-педагогічні завдання.

Для цього необхідно було з'ясувати чи готовий сьогодні вчитель до реалізації ідей компетентісно орієнтованого навчання і, які фрактори сприяють або не сприяють цій готовності.

3 метою з'ясування чи готові вчителі до реалізації компетентісно орієнтованого навчання було проведене дослідження, що полягало в опитуванні, анкетуванні, аналізі педагогічної діяльності.

Результати дослідження показали, що усвідомленням недостатності досягнутих результатів і бажанням їх поліпшити керуються в своїй інноваційній діяльності - 20\% педагогів; високим рівнем професійних досягнень, сильною потребою в досягненні високих результатів - 20\%; потребою в контактах 3 цікавими, творчими людьми - 53,3\%; бажанням створити нову, ефрективну школу для дітей - 20\%; потребою в новизні, оновленні, зміні обстановки, подоланні рутини - 26,6\%; потребою в лідерстві - 6,6\%; потребою в пошуку, дослідженні, кращому розумінні закономірностей - 20\%; потреба в самовираженні, самовдосконаленні - 20\%; відчуттям власної готовності брати участь в інноваційних процесах, упевненістю в собі - 20\%; бажанням перевірити на практиці отримані знання при нововведеннях - 6,6\%; потреба в ризику - 0\%; матеріальними причинами: підвищенням заробітної плати, можливістю пройти атестацію і т.д. - 46,6\%; прагненням бути поміченим і гідно оціненим $-40 \%$. 
Проведене дослідження дозволило виявити у педагогів наступні антиінноваційні бар'єри: слабка інформованість в колективі про можливі інновації - у 6,6\% педагогів; переконання, що ефективно навчати можна і постарому - у 20\%; погане здоров'я, інші особисті причини - у 33,3\%; велика навчальне навантаження - у 40\%; невеликий досвід роботи - у $20 \%$; відсутність матеріальних стимулів - у 40\%; почуття страху перед негативними результатами - у 20\%; розбіжності, конфрлікти в колективі - у 6,6\%.

Результати дослідження показали, що більшість педагогів сприймають нововведення помірно - 40\%, тобто не прагнуть бути серед перших, але й не хочуть бути серед останніх. Тоді як $26,6 \%$ педагогів відносять себе до тих, що володіють високим рівнем новаторства.

Однією $з$ основних причин подібної ситуації $\epsilon$ відсутність в школах інноваційного середовища - певної морально-психологічної обстановки, підкріпленої комплексом заходів організаційного, методичного, психологічного характеру, що забезпечують введення інновацій в освітній процес загальноосвітнього закладу освіти.

Перехід до нової української школи передбачає запровадження наступних інновацій: новий зміст освіти, заснований на формуванні компетентностей, потрібних для успішної самореалізації в суспільстві; умотивований учитель, який має свободу творчості й розвивається професійно; наскрізний процес виховання, який формує цінності; децентралізація та ефективне управління, що надасть школі реальну автономію; педагогіка, що ґрунтується на партнерстві між учнем, учителем і батьками; орієнтація на потреби учня в освітньому процесі, дитиноцентризм; нова структура школи, яка дає змогу добре засвоїти новий зміст і набути компетентності для життя; справедливий розподіл публічних коштів, який забезпечує рівний доступ усіх дітей до якісної освіти; сучасне освітнє середовище, яке забезпечить необхідні умови, засоби і технології для навчання учнів, освітян, батьків не лише в приміщенні навчального закладу [2].

Ефективним засобом удосконалення професійної діяльності вчителя $€$ розробка відповідного науково-методичного забезпечення. Під науковометодичним забезпеченням розуміємо сукупність форм і методів, що сприяють підвищенню рівня фрахової підготовки вчителя.

У процесі створення науково-методичного забезпечення враховуються наступні критерії:

1) суб'єктність педагога в його професійній діяльності, що виражається в авторському підході до постановки цілей, вироблення змісту занять, розробці засобів створення ситуації розвитку особистості вихованця;

2) адаптованість до індивідуально-стильових особливостей вчителя;

3) співавторство вчителя і учня в розробці всіх компонентів педагогічного процесу - його цілей, засобів, очікуваних результатів, критеріїв їх оцінювання;

4) забезпечення єдності особистісно-смислового та когнітивного розвитку учнів.

Науково-методичне забезпечення підготовки вчителя - це створення умов для формування творчої особистості педагога і підтримки професіональної форми його діяльності. Забезпечення цих умов сприяє розвитку у вчителя педагогічної системи, в якій він виявляє себе помічником дослідницької діяльності учнів, а також виробленню педагогічної техніки як помічника у творчій діяльності учнів, спрямованої на послідовне досягнення її творчої продуктивності. 
Найбільш поширеними формами роботи з вчителями $є$ вправи для самопідготовки, тренінги, творчі індивідуальні і групові завдання, практикуми, семінари та ін.

Використання запропонованого науково-методичного сприяє: підвищенню рівня професійної діяльності вчителів, їх методичної майстерності, що підтверджується при проведенні навчальних занять, в процесі атестації; зростанню творчого рівня методичної роботи 3 елементами експериментальної діяльності; підвищенню рівня педагогічної майстерності вчителя для реалізації ідей компетентісно орієнтованого навчання; укладанню комплексу методичного забезпечення, що відповідає вимогам навчальних стандартів, сприяє формуванню компетентності учнів; розвитку професійної компетентності, творчої індивідуальності вчителя, формування готовності до прийняття нового, розвиток сприйнятливості до педагогічних інновацій.

\section{Список використаних джерел:}

1. Про освіту (Проект Закону Українп). Вилучено із https://zakon.rada.gov.ua/laws/show/214519.

2. Софій, Н. З., Онопрієнко, О. В., Найда, Ю. М., Пристінська, М. С. \& Большакова, І. О. (2017). Нова українська школа: порадник для вчителя. Н. М. Бібік (ред.) Київ: ТОВ «Видавничий дім «Плеяди».

\section{ПІДГОТОВКА МАЙБУТНІХ ВЧИТЕЛІВ ДО СУБ'ЄКТ- СУБ’ЄКТНОї ВЗАєМОДії З ДІТЬМИ МОЛОДШОГО ШКІЛЬНОГО ВІКУ}

Блудова Юлія Олександрівна
кандидат педагогічних наук, викладач кафедри педагогіки, психології,
початкової освіти та освітнього менеджменту
Комунальний заклад «Харківська гуманітарно-педагогічна академія»
Харківської обласної ради
Єдименченко Юлія Миколаївна
Кдобувач вищої освіти психолого-педагогічного факультету
Харківської обласної ради
УКРАїнА

Інтеграція України в європейський освітній простір висуває конкретні вимоги до майбутніх фахівців та їх підготовки. Актуальними стають уміння ставити перед собою цілі та досягати їх, реалізовувати Концепцію Life Long Learning, розвивати критичне мислити, співпрацювати в команді, спілкуватися в багатокультурному середовищі тощо. Однак, як зазначено в Концепції нової української школи, сучасна освіта не готує до цього. Суспільство зацікавлене в тому, щоб на практиці забезпечити плідну співпрацю, вчителів, батьків і дітей 
на засадах взаємної довіри й поваги, досягти балансу прав, обов'язків і відповідальності.

Культурні цінності та соціальне замовлення зумовлюють гуманізацію як основну тенденцію реформування освіти, зокрема професійної. Сучасна ситуація в професійній педагогічній освіті відзначається виникненням нових парадигм та наукових підходів до побудови освітнього процесу. Нові освітні тенденції в Україні вимагають зміни педагогічного мислення, свідомості та рольової позиції педагога. Найважливішим завданням вчителя в контексті сучасних освітніх рефрорм є педагогічна фрасилітація, що полягає у спрямуванні інформаційних потоків, виявленні розмаїття дитячих думок, звернення до особистісного досвіду дітей, підтримка їхньої активності, взаємозбагачення досвіду, полегшення сприйняття та засвоєння, заохочення творчості. Оскільки головною умовою реалізації педагогіки співпраці в освітній практиці $\epsilon$ особистість учителя, а конкретніше - його суб'єктність, на сьогоднішній день надзвичайно актуальною є проблема формування суб'єктної позиції майбутніх педагогів з учнями молодшого шкільного віку.

На законодавчому рівні нові підходи до професійної підготовки майбутніх вчителів знайшли відображення в Національній доктрині розвитку освіти (2002), Законі України «Про освіту» (2017), «Про вищу освіту» (2014), Державній програмі «Вчитель» (2002), Концепції Нової української школи (2016), Державному стандарті початкової загальної освіти (2018). У цих та інших нормативних актах наголошується на необхідності підготовки вчителя як високопрофесійного фахівця, зорієнтованого на особистість дитини, здатного до захисту її інтересів, розвитку і збереження її індивідуальності, спроможного до ефективної професійної діяльності на засадах гуманістичної педагогіки.

Акцентуючи увагу на те, що сучасні завдання професійної підготовки майбутніх учителів мають бути орієнтовані на формування нового стилю педагогічного мислення, свідомості та рольової позиції вчителя, науковці наголошують, що ця проблема ускладнюється тим, що педагогу традиційної школи притаманна інертність, що характерними для неї є певні стереотипи в поведінці, зокрема, роль авторитарного наставника. Особливо це стосується учителя початкових класів, який домінує над учнями в процесі взаємодії, тоді як вікові характеристики молодшого школяра потребують особливих підходів до організації співпраці з ними [3].

Особливої актуальності сьогодні набуває питання суб'єкт-суб'єктної взаємодії вчителя й учня. Тому предметом наукових досліджень Ю. Богданової, Л. Кондрашової, С. Манукової, Р. Ню, О. Проскури, Г. Штельмах та інших стали питання формування готовності майбутніх учителів до певних видів педагогічної діяльності. Вагомими у дослідженні теоретико-методологічних і технологічних основ професійно-педагогічної підготовки майбутніх учителів початкових класів $€$ результати наукових пошуків Ш. Амонашвілі, Н. Бібік, В. Давидова, Д. Ельконіна, Л. Занкова, В. Ковальова, Г. Пономарьової, О.Савченко, В. Ставицького, В. Сухомлинського, Л. Хомич.

Сучасні наукові підходи до висвітлення окремих аспектів проблеми підготовки майбутніх учителів до суб'єкт-суб'єктної взаємодії вчителя та учня знайшли відображення в працях таких українських вчених: І. Бех, І. Зязюн, 
О. Пехота, С. Подмазін, О. Савченко, А. Старєва та ін.). Цю ж проблему досліджували й зарубіжні науковці: Р. Барт, С. Дженсенсон, С. Кульневич, Д. Роббенс, В. Сєріков, І. Якиманська та ін.

У тлумаченні поняття суб'єктної позиції можна виокремити кілька загальних тенденцій: свідома форма буття; системна якість особистості, що поєднує такі якості, як свобода, самостійність, відповідальність, ініціативність, творчість, оригінальність, активність, відповідальність; здатність до саморозвитку; взаємозв'язок різних якостей та процесів.

Незважаючи на значну увагу вчених до цієї проблеми, практика підготовки майбутнього вчителя початкових класів до організації суб'єкт-суб'єктної взаємодії в сучасному ЗВО засвідчує відсутність системного підходу до ії реалізації, що виявляється у фрагментарному впровадженні окремих тем чи спецкурсів на загальнопедагогічному чи методичному рівнях змісту професійної педагогічної підготовки [1].

На підставі теоретичного аналізу літературних джерел і вивчення практичного досвіду визначено, що для сучасної освіти характерно загострення наступних протирічь: між новими ціннісно-цільовими орієнтирами в освіті, спрямованими на партнерство (діалог) дорослого і дитини, і існуючим монологічним типом взаємодії «вчитель-учень» в традиційній системі освіти; між зростанням внутрішньої свободи учня і психологічним, професійним самопочуттям педагога, його рольовою негнучкістю; між темпами зміни соціальних умов сучасного життя і відсутністю нових освітніх технологій, що сприяють підготовці молодшого школяра до адаптації у мінливому світі; між індивідуальною потребою педагога здійснювати свою професійну діяльність у новому освітньому просторі та традиційним укладом освітніх установ [2].

Нині перед сучасною школою стоїть соціальне замовлення - виховання грамотної особистості, здатної взаємодіяти з іншими людьми. То ж важливим завданням сучасного учителя - пошук нових способів інтенсифікації навчання, підвищення його якості. Нині заклади загальної середньої освіти шукають найбільш результативні методи навчання і виховання. I оскільки така взаємодія може розвинутися, і ссормуватися в процесі здобуття освіти, починаючи з самого раннього дитинства, то особлива роль відводиться періоду навчання в початковій школі, де в процесі освітньої діяльності, під керівництвом учителя формується навчальна співпраця. Найважливішим засобом досягнення цієї мети $€$ організація на уроці педагогічного співробітництва, під яким мають на увазі різні види спільної роботи, спрямованої на вирішення навчальних завдань завдань.

\section{Список використаних джерел:}

1. К Карпинский, К. (2002). Человек как субъект жизни. Київ-Гродно: ГрГУ.

2. Левченко, Т. (2002). Розвиток освіти та особистості в різних педагогічних системах. Вінниця: Вид-во «Нова книга».

3. Ліннік, О.О.(2014). Майбутній учитель як суб’єкт педагогічної взаємодії: підготовка до співробітництва з молодшими школярами. Київ: Видавничий Дім «Слово». 


\section{ПІДГОТОВКА МАЙБУТНІХ ВЧИТЕЛІВ ДО ФОРМУВАННЯ ЕКОЛОГІЧНОЇ ГРАМОТНОСТІ МОЛОДШИХ ШКОЛЯРІВ У ПОЗАКЛАСНІЙ РОБОТІ}

Толмачова Ірина Миколаївна

кандидат педагогічних наук, доцент, професор кафедри педагогіки психології, початкової освіти та освітнього менеджменту Комунальний заклад «Харківська гуманітарно-педагогічна академія» Харківської обласної ради

Бєлкіна Інна Володимирівна здобувач вищої освіти психолого-педагогічного факультету Комунальний заклад «Харківська гуманітарно-педагогічна академія» Харківської обласної ради УКРАÏHA

Упродовж останніх десятиріч істотно погіршився екологічний стан довкілля, а проблеми екології досягли планетарного масштабу й утворюють нову соціальну реальність. Розв'язання цих проблем залежить перш за все від рівня екологічної культури населення. Кожен громадянин має володіти певною базою екологічних знань, що дозволить розуміти й оптимально розв'язувати екологічні проблеми на основі наукових знань процесів розвитку біосфери, загальнолюдського досвіду й цінностей. Можна стверджувати, що саме шкільній екологічній освіті сьогодні належить провідне місце серед складових принципів створення фундаменту екологічної безпеки України.

Тому сьогодні перед сучасною школою й учителями постає питання про організацію освітнього процесу, що орієнтований на екологічну освіту формування екологічних компетентностей у підростаючого покоління як запоруки збереження навколишнього середовища [2].

Концепція «Нова українська школа» зазначає, що однією з учнівських ключових компетентностей $є$ екологічна грамотність, тобто «уміння розумно та раціонально користуватися природними ресурсами в рамках сталого розвитку, усвідомлення ролі навколишнього середовища для життя і здоров'я людини» [3].

У Державному стандарті початкової освіти екологічна компетентність визначається як одна 3 ключових компетентностей, що передбачає усвідомлення основи екологічного природокористування, дотримання правил природоохоронної поведінки, ощадного використання природних ресурсів, розуміючи важливість збереження природи для сталого розвитку суспільства.

У формуванні екологічної грамотності провідна роль належить початковій школі, яка є однією з перших ланок становлення людини-громадянина. Основні риси характеру особистості формуються у ранньому дитинстві, і спілкування 3 природою посідає чільне місце у дитини молодшого шкільного віку. Щоб забезпечити ефрективне формування екологічної компетентності в учнів початкових класів вчителям необхідно виокремити екологічний потенціал в кожному навчальному предметі. Провідна роль беззаперечно належить природничій та соціальній і здоров'язбережувальній освітнім галузям та не 
виключенням $€$ мовно-літературна, мистецька, фрізкультурна галузі та інші, під час вивчення яких можливе формування наукової основи природоохоронної діяльності молодших школярів [5].

Мету, зміст, завдання, загальні принципи, форми і методи екологічної освіти, формування екологічної культури в педагогіці досліджувались С. Дерябо, А. Захлєбним, І. Зверьєвим, Г. Пономарьовою, Г. Пустовійтом, І. Суравегіною, В. Ясвіним та іншими вченими. Основою еколого-виховного процесу багато науковців вважають виховання ціннісного ставлення школярів до природи (В. Додь, В. Маршицка, О. Колонькова, М. Левківський, Н. Николенко, О. Пруцакова, Л. Хуртенко, Т. Юркова та інші вчені). Принципи і складники екологічної культури висвітленіо в дослідженнях О. Вознюк, Т. Дементьєва, В. Ковальчук, І. Лушнікова, Є. Ногтєвої, В. Тернопільської, В. Павловіча та інших учених.

Формування екологічної компетентності, як педагогічну проблему, досліджували в своїх роботах педагоги (А. Захлєбної, І. Звєрєва, І. Зязюна, О. Савченко) та психологи (В. Вербицького, С. Дерябо, В. Ясвіна, Е. Гірусов, М. Дробнохода, В. Безрукова, Ф. Войно-Ясенецького, А. Дворкіна, Н. Кисельова) та ін. Дані дослідження свідчать про необхідність внесення коректив в основні структурні компоненти екологічної освіти, які сприятимуть фрормуванню екологічної компетентності учнів початкових класів.

Молодший шкільний вік є найбільш сприятливим періодом для формування основ екологічної культури тому, що в цей період розвитку дитини характерним $€$ перевага емоційно-чуттєвого способу освоєння навколишнього світу, інтенсивно формуються властивості і якості особистості, які визначають їі сутність в майбутньому. У цьому віці у свідомості учнів відбувається формування наочно-образної картини світу і морально-екологічної позиції особистості, яка визначає ставлення дитини до природного і соціального оточення і до самого себе. Яскравість і чистота емоційних реакцій обумовлюють глибину і стійкість вражень, що одержує дитина. Дитина молодшого шкільного віку починає також виявляти цікавість до світу людських відносин і знаходити своє місце в системі цих відносин, його діяльність набуває особистісної природи і починає оцінюватися з позицій законів, визнаних в суспільстві [1].

То ж завданням екологічного виховання в рамках організації освітнього процесу в початковій школі $€$ : формування в учнів наукових уявлень про взаємодію людини з природним середовищем, про закономірності функціонування і розвитку природи як глобальної системи; виховання у молодого покоління ціннісних орієнтацій і моральних ідеалів екологічного характеру; розвиток інтелектуальних здібностей молодших школярів щодо здійснення екологічної оцінки конкретної ситуації; формування в учнів початкових класів умінь і навичок екологічної діяльності та екологічно доцільної поведінки у взаємодії з об'єктами живої і неживої природи.

Формування екологічної грамотності молодших школярів - це складний процес, що вимагає комплексної взаємодії класної та позакласної роботи [4].

Позакласна робота створює умови для набуття досвіду прийняття екологічних рішень на основі отриманих знань і згідно зі сформованими цінностями підходами і орієнтаціями. 
Формування екологічної культури молодших школярів можливо тільки за умови взаємозв'язку різних типів і видів позакласної діяльності. Різноманітна діяльність дає можливість школярам оволодіти глибокими знаннями про зв'язки людини з природою, побачити екологічні проблеми в реальному житті, навчитися найпростішим умінь з охорони природи.

На підставі теоретичного аналізу літературних джерел і вивчення практичного досвіду визначено, що для сучасної освіти характерно загострення наступних протиріч:

- між актуальною потребою у формуванні екологічної грамотності молодого покоління і недостатньою результативністю екологічної освіти в закладах загальної середньої освіти;

- між збільшеною потребою сучасного суспільства у формуванні особистості, яка має високий рівень екологічної культури, і недостатньою розробленістю теорії розвитку і реалізації концепції становлення екологічної культури молодших школярів у процесі позакласної роботи.

Дані протиріччя трансформуються в актуальну наукову проблему: які педагогічні умови, що детермінують формування екологічної грамотності молодших школярів у позанавчальній діяльності.

Таким чином, актуальність, теоретична і практична значущість, недостатня розробленість проблеми стосовно до сучасних умов, протиріччя, що існують в освітній практиці, зумовили звернення до цієї теми.

Тож ключовою фрігурою у формуванні екологічної грамотності молодших школярів $\epsilon$ учитель. Тому фахова підготовка студентів - майбутніх вчителів початкових класів, їх екологічна освіта, культура, готовність до природоохоронної та еколого-натуралістичної роботи з дітьми, громадянська позиція і, зрештою, екологічна компетентність $€$ невід'ємною складовою процесу професійної підготовки у ЗВО.

\section{Список використаних джерел:}

1. Курняк, Л. Д. (2006). Екологічна культура: поняття і реальність. Вища освіта України, (3), 32-37.

2. Пономарьова, Г. Ф. (2005). Формування екологічної культури майбутнього вчителя.

3. Про схвалення Концепції реалізації державної політики у сфері реформування загальної середньої освіти "Нова українська школа" на період до 2029 року. Вилучено 3 http://osvita.ua/legislation/Ser_osv/54258/.

4. Пустовіт, Н. А., Пруцакова, О. Л., Руденко, Л. Д. \& Колонькова, О. О. (2008). Формування екологічної компетентності школярів. Київ.

5. Савченко, О. Я. (2001). Удосконалення професійної підготовки майбутніх учителів початкових класів. Початкова школа, (7), 1-4. 


\title{
ПРОПЕДЕВТИЧЕСКОЕ ИЗУЧЕНИЕ КАТЕГОРИЙ ТЕКСТА
}

\author{
Кон Олена Олександрівна \\ кандидат філологічних наук, доцент, \\ доцент кафедри слов'янського мовознавства \\ Південноукраїнський національний педагогічний університет
}

УKPAÏHA

Современное состояние лингвистической теории в области синтаксиса отмечено обилием систем и концепций, свидетельствующих о глубоком и всестороннем изучении синтаксической системы языка в целом, и ее основных синтаксических единиц [1]. Все это прямо или косвенно отражается на практике обучения русскому языку в школе, на становлении и совершенствовании синтаксических компетенций учащихся младшего школьного возраста.

Начальное обучение языку предполагает пропедевтическую работу по формированию у школьников знаний о единицах различных языковых уровней (текст, предложение, слово в его лексическом и грамматическом значении, звуки речи). При этом главное внимание должно уделяться практическим аспектам: работе над значением слова и количественному росту словарного запаса учащихся, обогащению их речи различными грамматическими формами, развитию умения пользоваться языковыми средствами в соответствии с нормами литературного языка (орфоэпическими, лексическими, грамматическими, орфографическими), умения анализировать, оценивать собственные речевые произведения, совершенствовать их, умения пользоваться алфавитом, учебными словарями и другой справочной литературой [2].

Чтобы информация из разных областей языкознания не имела разрозненный характер, она должна опираться на сведения из лингвистики текста. Это позволит реализовать первостепенную задачу начального обучения языку - формирование у младших школьников речевых навыков, умений строить связные высказывания.

Целостное изучение языковой системы возможно только с опорой на текст как основной дидактической единицы, такой единицы языка, которая выражает законченное высказывание.

Такое построение программы, где в основе курса лежит текст, позволило уже на начальном этапе обучения языку формировать у учащихся пропедевтические знания и умения относительно текста, а позже, в процессе изучения лексико-грамматического и фонетико-орфографрического материала, закреплять эти знания и добиваться осознанного использования их в практической речевой деятельности.

Активно разрабатываемая в последние десятилетия теория текста (лингвистика стилистики, грамматики, семантики, прагматики текста) предоставила возможность выбора теоретических материалов в области текста для изучения в начальной школе и использования этих знаний для выработки у учащихся специальных коммуникативно-речевых умений, 
которые базируются на теории текста.

Для начальной школы, когда формируются первичные, но в то же время основные знания о тексте, оказались необходимыми (важными) знания конституирующих признаков текста (существенные характеристики в плане его), т. е. знания основных текстовых категорий.

Само понятие «категории текста», введенное в лингвистический обиход И.Р.Гальпериным, связано прежде всего с попыткой выделить и описать основные признаки текста в дихотомии текст /не текст [3].

Выявление и описание категорий текста в настоящее время является одной из основных задач лингвистики текста.

Категории текста не совпадают с категориями предложения и возникают вместе с текстом как системой высшего ранга. Это категории особого рода, характеризующие отрезки большие, чем предложения. Само понятие «категория текста» не получило однозначного терминологического определения. Не останавливаясь на дискуссионности данного понятия, ограничимся указанием на то, что категории текста отображают наиболее общие и существенные свойства, признаки текста и номенклатура этих категорий у разных исследователей разная [3].

Например, И.Р.Гальперин выделяет такие важнейшие текстовые категории, как: информативность, членимость, когезия (внутренние связи), континуум (временной и пространственный), ретроспекция и проспекция, модальность, автосемантия, интеграция и завершенность [3]. Все категории текста взаимосвязаны и взаимообусловлены. Все это обеспечивает целостность текста.

Некоторые лингвисты сходятся во мнении, что целесообразно разделить все категории текста на две основные группы. В первую группу войдут категории, которые представляют собой признаки его структуры, во вторую особенности его содержательной стороны. Первые условно назвали структурными, вторые - содержательными, или концептуальными. Эти категории взаимообусловлены. Однако если первые присущи тексту как лингвистическому объекту, то вторые характеризуют процесс отражения в тексте объективной действительности. Первые заложены в самой структуре текста, вторые осуществляют связь между текстом и объективной действительностью, отраженной и преломленной в тексте. В первую группу войдут такие категории, как: сцепление, интеграция, прогрессия, стагнация; во вторую - образ автора, художественное пространство и время, информативность, причинность, подтекст и др. [4; 5]

Общепризнанной в лингвистике текста является также дифференциация текстовых категорий на общетекстовые (характерные для всех текстов) и частные (специфические) [6].

Категории текста носят характер универсалий и обнаруживаются в связном тексте независимо от языка, на котором создан данный текст, и независимо от типа текста [7].

Таким образом, современное состояние лингвистической науки в области теории текста и разработка этой проблемы в методике обучения языку в среднем звене общеобразовательной школы послужили основой для определения основных категориальных характеристик текста, которые стали предметом изучения в начальных классах.

Это прежде всего такие важнейшие текстовые категории, как 
инфрормативность, которая рассматривается в начальной школе посредством определения о ком или о чем говорится в тексте; членимость, интегративность и завершенность, реализуемые соответственно в понятиях структура текста, план, тема и основная мысль. Уделяется внимание и такой важнейшей категории, как связность (когезия /внутренние связи), которая реализуется на разных уровнях организации текста и осознается младшими школьниками на содержательном, композиционносмысловом и лексическом уровнях.

Сегодня не только современные теоретические исследования, но и достаточно широкая практика доказали целесообразность и возможность ознакомления учащихся младших классов с понятием «текст» и некоторыми его признаками уже с первого года изучения курса языка.

Тема „Текст” начинает раздел программы по русскому языку в качестве ее основного языкового компонента. В целом программа предусматривает усвоение определенных лингвистических знаний в области теории текста и формирование на их основе соответствующих умений. Так, учащиеся начальной школы должны знать основные признаки текста и уметь различать текст и не текст, делить текст на структурно-смысловые части и озаглавливать их, составляя, таким образом, план текста, различать функциональносмысловые типы текстов - описание, повествование, рассуждение, знать их особенности и уметь составлять текст определенного типа.

Все перечисленные сведения в области теории текста вводятся в процесс обучения русскому языку через систему упражнений, организующих непосредственные наблюдения за соответствующими языковыми явлениями.

Распределение материала по классам выглядит следующим образом.

Так, во 2 классе объектами изучения становятся само понятие „текст”, тема текста, основная мысль текста, опорные слова, а также композиционная структура текста: зачин, основная часть и концовка.

В результате усвоения этих знаний учащиеся должны уметь выбирать узкую и широкую тему из данного перечня тем, соотносить тему с текстом, определять основную мысль текста, озаглавливать текст, по опорным словам составлять текст.

В 3 классе формируется умение понять и выделить основную мысль текста, определить тему текста; работу над элементарными изобразительновыразительными средствами художественного текста, составление плана к тексту, а также составление текста по плану.

Итак, к концу 3 класса учащиеся получают основные знания теории текста и у них сформированы основные умения по разбору текста.

В 4 классе расширяются знания о тексте, развиваются и совершенствуются умения в построении текстов разных типов, осуществляются наблюдения за особенностями художественных, научных и деловых текстов. У учащихся формируют умения строить и совершенствовать текст, умение анализировать содержание, структуру и языковые особенности текстов.

Такое структурирование учебного материала представляется оправданным, так как к 4 классу знания теории текста младшими школьниками в основном получены, и задача последнего года начального языкового образования заключается в повторении теоретического материала и 
совершенствовании языковых умений и навыков в области текста.

Вынесение раздела «Текст» в основу построения начального курса русского языка дает возможность успешнее решать проблемы межпредметных связей, в частности знания о тексте, полученные на уроках языка успешно используются на уроках литературного чтения при изучении художественных текстов. Усвоение младшими школьниками лингвистических знаний о тексте позволяет реализовать взаимосвязи между усвоенными ими теоретическими знаниями о языке и умениями в области связной речи, развитием речи в целом.

\section{Список використаних джерел:}

1. Валгина, Н. С. (2000). Синтаксис современного русского языка. Москва: АСТ.

2. Данильченко, Н. И. \& Дацюк, О. В. (2014). Содержание изучения синтаксиса в начальной школе в условиях реализации новых государственных стандартов. Актуальні питання слов'янського мовознавства, (9), 146-157.

3. Гальперин, И. Р. (1981). Текст как объект лингвистического исследования. Москва: Наука.

4. Реферовская, Е. А. (1983). Лингвистические исследования структуры текста. Ленинград: Наука.

5. Тураева, 3. Я. (1986). Лингвистика текста (Текст: структура и семантика). Москва: Просвещение.

6. Селиванова, Е. А. (2002). Основы Лингвистической теории текста и коммуникации: Монографическое учебное пособие. Киев: Издательство украинского фитосоциологического центра.

7. Солганик, Г. Я. (2001). Стилистика текста. Москва: Флинта.

\section{ПСИХОЛОГІЧНІ АСПЕКТИ ВИКОРИСТАННЯ ІНФОРМАЦІЙНО-КОМУНІКАЦІЙНИХ ТЕХНОЛОГІЙ В OCВITHЬOMУ ПРОСТОРI}

\section{Тищенко Микола Андрійович \\ викладач \\ Національний технічний університет України «Київський політехнічний інститут імені Ігоря Сікорського» \\ УКРӒ̈НА}

3 розвитком мультимедійних засобів інформаційні технології швидко змінюють усі сфери діяльності людини, від виробництва до повсякденного життя. Ці зміни також стосуються і галузі освіти, але рівень вивчення питання вжитку освітніх інформаційно-комунікаційних технологій у вищих навчальних закладах не є детально дослідженим, що і являє собою актуальність розгляду цього питання.

Вже давно поняття E-learning часто зустрічається в наукових роботах вітчизняних та закордонних дослідників. У своїх роботах вони досліджують психологічну готовність викладачів іноземної мови та студентів до навчання із 
використанням інноваційних засобів навчання, не забуваючи приділяти увагу гендерній та віковій різниці освітян та учнів.

Змінились не лише засоби навчання, а й роль викладача та студента. Розглядаючи класичну методику навчання іноземній мові, викладач виступав у ролі більш авторитарного «джерела» інформації, а студент міг лише пасивно отримувати інформацію, покращуючи свої навички в тому чи іншому питанні. Зараз ситуація кардинально змінилась. Завдяки комунікаційній методиці навчання іноземних мов викладач став свого роду «путівником», який мотивує та спрямовує студентів до взаємодії за навчальним матеріалом. Цей підхід має надзвичайні переваги над традиційною методикою викладання іноземних мов, оскільки дає змогу студенту зануритись у навчальне середовище та проявляти свою креативність, шукати більш зручні методи отримання знань.

Слід відмітити, що в галузі освіти змінились не лише методичні підходи до навчання, а й засоби та інструменти надбання знань. Дякуючи прогресу в галузі інформаційних технологій, сьогодні ми можемо бачити оснащені мультимедійними засобами навчання учбові аудиторії, лінгафонні кабінети тощо.

Чудовим прикладом впровадження інноваційних засобів навчання в освітнє середовище $€$ національний технічний університет України «Київський політехнічний інститут імені Ігоря Сікорського», де на кожному фракультеті $\epsilon$ окремі аудиторії, виділені саме для вивчення іноземної мови. Майже всі вони оснащені персональними комп'ютерами, проекторами та аудіо системами, що підвищує можливість студентів покращувати свої навички англомовного мовлення.

Що стосується психологічної готовності викладачів національного технічного університету України «Київський політехнічний інститут імені Ігоря Сікорського», можна зазначити, що усі викладачі активно застосовують вище зазначені засоби навчання, а, за потреби навчитись використанню нових технологій, вони відвідують безкоштовні семінари або звертаються до Українського інституту інформаційних технологій в освіті, де мають змогу безкоштовно пройти курс підвищення кваліфікації та отримати необхідні знання.

\section{Список використаних джерел:}

1. Тищенко, М. А. Сайт "КПІ ім. І. Сікорського". Вилучено з https://kpi.ua/.

2. Тищенко, М. А. Сайт "УІІТО". Вилучено з http://uiite.kpi.ua/. 


\title{
PЕАЛІЗАЦІЯ ТЕХНОЛОГІЇ ВRING YOUR OWN DEVICE НА ПРАКТИЧНИХ ЗАНЯТТЯХ 3 «ПРАКТИЧНОЇ ГРАМАТИКИ АНГЛІЙСЬКОї МОВИ»
}

\begin{abstract}
Гурський Ігор Юрійович
викладач-стажист кафедри теорії та практики іноземних мов Уманський державний педагогічний університет імені Павла Тичини

УКРАÏHA
\end{abstract}

Чільне місце у професійній підготовці бакалаврів освіти (педагогіки), вчителів англійської мови НУШ за спеціальністю 014 Середня освіта; предметною спеціалізацією 014.02 Середня освіта (Мова і література (англійська)) відводиться дисципліні «Практична граматика англійської мови», яка в комбінації з іншими курсами «Практична фонетика англійської мови» та «Практика усного та писемного мовлення» дозволить майбутньому фахівцеві рухатися індивідуальною траєкторією професійного розвитку в майбутньому. На сьогодні викладачі закладів вищої освіти перебувають у постійному пошуку ефективних способів проектування якісного освітнього середовища на заняттях із «Практичної граматики англійської мови». На наш погляд, одним із таких способів $є$ технологія Bring Your Own Device (BYOD), яка передбачає широке використання ґаджетів студентів в освітньому процесі.

Як видно із рис. 1, використання технології BYOD є способом упровадження IКТ в освітній процес вищої школи в умовах відсутності належної матеріальнотехнічної бази закладу освіти. Крім того, дана технологія $є$ передовим освітній трендом, який $є$ інструментом розбудови ґаджетизованої освіти в епоху трансформаційних змін.

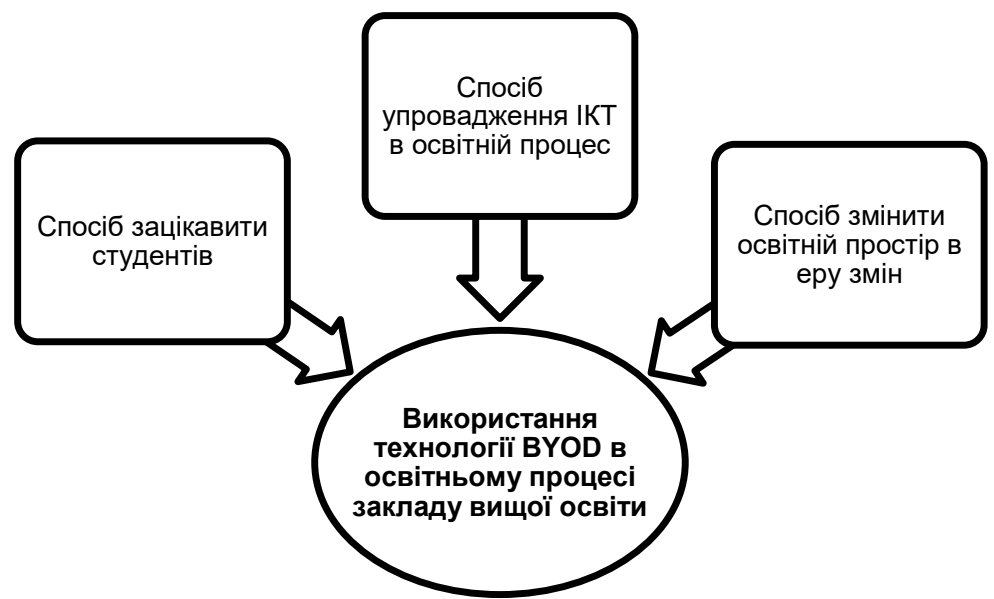

Рис. 1. Використання технології BYOD в освітньому процесі закладу вищої освіти 
Як стверджує К. Плєвако, суттєвою перешкодою у впровадженні технології в закладах загальної середньої освіти є: «недостатній рівень інформаційної компетентності та відсутність методичних рекомендацій для проведення таких уроків» [2]. Погоджуючись із наведеною точкою зору, ми можемо ствержувати, що використання цієї технології може стати «викликом» для педагогів, оскільки технічні характеристики девайсів студентів можуть викликати суттєві труднощі у процесі планування заняття. Існує ймовірність того, що студент може залишити свій ґаджет вдома, або не взяти зарядний пристрій до закладу освіти. Крім того, при великій різноманітності ґаджетів їхній функціональний діапазон суттєвою мірою відрізняється.

У контексті реалізації технології BYOD викладач може запропонувати студентам прослуховування змістовних та захоплюючих граматичних аудіозаписів, які у стислій та лаконічній формі дозволяють опанувати граматичний матеріал. Наприклад, аудіозаписи тематичної рубрики «6 Minute Grammar», запозичені із Інтернет-ресурсу «ВBC. Learning English» сприятимуть знайомству студентів із новими граматичними поняттями, структурами в контексті.

Реалізовуючи концепцію, викладач може створити власні граматичні тести та запропонувати їхнє виконання на практичному занятті у режимі онлайн. Це дасть змогу не лише виявити рівень знань студентів, але й з'ясувати, який граматичний матеріал слід опрацювати на занятті додатково.

Із метою стимулювання інтересу до опанування граматики англійської мови викладач може запропонувати студентам створити власні граматичні блоги, які дадуть змогу студентам показати відеозаписи із власними поясненнями граматичного матеріалу та власні схеми, таблиці, які узагальнюватимуть вивчений граматичний матеріал. Обов'язковою умовою має стати єдина тема для всіх. Студенти повинні проаналізувати блоги один одного та переглянути відеозаписи, аби визначити найкращого граматичного блогера академічної групи.

Узявши до уваги наведені приклади реалізації освітньої технології BYOD, ми маємо підставу стверджувати, що вона, як зазначають В. Андрієвська та Л. Білоусова, сприяє розвитку пізнавальної активності, ініціативності студентів та формує здатність ставити перед собою проблеми та знаходити ефективні шляхи їхнього вирішення [1].

Висновки. На сучасному етапі технологія BYOD $€$ своєрідним «будівельним матеріалом», із якого викладач англійської мови може сконструювати середовище для ефективного оволодіння граматичним матеріалом студентами.

\section{Список використаних джерел:}

1. Андрієвська, В. М. \& Білоусова Л. І. (2017). Концепція BYOD як інструмент реалізації STEAM-освіти. Фізико-математична освіта, 4 (14), $13-17$.

2. Плєвако, К. Способи практичної реалізації концепції BYOD у загальноосвітніх закладах. Інфрормаційні технології - 2015: зб. тез І/ Всеукраїнської молодих науковців (с. 54-56). 2829 травня 2015, Київ, Україна: Київський університет імені Бориса Грінченка. 


\title{
РОЗВИТОК МОВЛЕННЄВИХ КОМПЕТЕНЦІЙ У ПРОЦЕСІ ВИВЧЕННЯ ІНОЗЕМНОÏ МОВИ ЗА ПРОФЕСІЙНИМ СПРЯМУВАННЯМ
}

\author{
Демченко Наталія Сергіївна \\ Білоцерківський національний аграрний університет
}

УКРАЇНА

Нове тисячоліття поклало початок справжнім змінам у багатьох сферах життя, а особливо у сфері економіки. Як результат, сьогодні в умовах зростаючої глобалізації міжнародного бізнесу та економіки, знання англійської мови є вкрай необхідним. Успішна кар'єра у сфері бізнесу напряму залежить від володіння англійською мовою.

Потреба в хороших фахівцях ускладнює вимоги до іноземної мови як навчального предмета, що викликає необхідність активізації іншомовної освіти за рахунок застосування сучасних методів навчання, які наближують навчальний процес до реальності і що імітують ситуації професійної діяльності, тому навчання іноземної мови має носити комунікативноорієнтований і професійно-направленний характер для успішного виконання подальшої професійної діяльності.

Іншомовна комунікативна компетентність $€$ інтегральною характеристикою професійної діяльності фрахівця. Іншомовна компетентність - це комплекс знань, умінь, навичок, які дозволяють успішно використовувати іноземну мову як у професійній діяльності, так і для самоосвіти і саморозвитку особистості [4].

Метою навчання говорінню студента-економіста $€$ вміння виступати як 3 підготовленим, так і непідготовленим повідомленням, вміння вести діалог 3 партнерами (в майбутньому з колегами, клієнтами і т.д.) і адекватно реагувати на репліки свого співрозмовника, приймати участь в дискусіях, обговореннях, вміти описувати графіки і робити презентації [3].

Навик вільного говоріння неможливий без широко словникового запасу,тому нарощування вокабуляра $€$ необхідним завданням. Усне мовлення вимагає значної підготовчої роботи, перш ніж стати дійсно продуктивними вміннями. Наприклад, під час вивчення теми «Entrepreneurship», презентація нової лексики відбувається на основі тексту. Потім студент закріплює дану лексику через виконання низки спеціально розроблених вправ: match the phrases with their meaning, complete the sentences with given phrases/ words, answer the following questions (питання розроблені таким чином, що відповіді будуть включати пройдений матеріал). Після відпрацювання лексики студенту пропонуються більш вільні форми вираження, наприклад, додаткові висловлювання, трансформація або особистісно-орієнтовані висловлювання. Студенти готують повідомлення на запропоновані теми з точки зору їх сприйняття, наприклад: «Why do so many new businesses not survive? What are the risks of buying an existing company? Is seller financing a good idea from the seller's point of view? Would you prefer to buy a company or start your own business/franchise? Why?» 
Також існують і творчі завдання. Досить цікавими видами творчої роботи $€$ різні проектні роботи, що вимагають серйозної і ретельної підготовки. При роботі над проектом студенти виявляють свої творчі та професійні навички [1]. Проекти можуть бути індивідуальними, парними та груповими. Результат роботи може бути представлений - презентацією в Power Point, плакатами, відео чи аудіо записами, web-сайтами тощо, все залежить від поставленого завдання та творчих навиків студента. Прикладом такої роботи може послужити наступна проектна робота, мета якої представити новий продукт компанії. Завдання:

Topic

The launch of your company's new product

Plan

1 The background to the launch

2 The features of the new product

3 The advertising and marketing plans

Aim

To give a clear idea of the sales potential of the product

Основними цілями застосування проектної роботи на заняттях $є$ розвиток творчого потенціалу та критичного мислення, нарощування обсягу лінгвістичних і соціокультурних знань, підвищення мотивації до оволодіння англійською мовою, спонукання до власних роздумів, пошук оригінальних рішень, вміння правильно та логічно подавати інформацію.

В умовах професійно-орієнтованого навчання англійської мови використовуються також діалоги-зразки. Діалог-зразок $є$ опорою і орієнтиром у змістовному плані спілкування. Він також показує соціокультурні особливості носіїв мови, а також особливості їх мовного спілкування. Дані аспекти необхідно знати, тому що студент-економіст повинен вміти вести ділові та телефонні переговори, проводити презентації, виступати на конференціях англійською мовою. Тому так важливо навчити студентів правильного діалогічного мовлення [2]. На заняттях потрібно надавати їм якомога більше діалогів на різноманітні теми, навчити їх фразам на різні теми як: networking, exchanging contact details, updating and delegating tasks, making and changing arrangements, teleconferencing, making suggestions and recomendations, presenting new ideas та інші.

Використання описаних вище методів абсолютно виправдано при навчанні студентів, оскільки дозволяє забезпечити оволодіння професійними i комунікативними компетенціями, здібностями самостійно організовувати свою навчальну діяльність, активно і творчо брати участь в обговоренні та аналізі вивченого матеріалу, а також вміло застосовувати накопичені знання і вміння на практиці. До того ж, такі методи урізноманітнюють заняття, за рахунок чого підвищується зацікавленість предметом, розвивається вміння працювати в команді, аналізувати вивчений матеріал та збільшити активність роботи на заняттях.

\section{Список використаних джерел:}

1. Гаврилова, Е. А. (2016). Использование телекоммуникационных проектов в обучении иностранному языку профессионального общения в экономическом вузе. Языковые и профессиональные компетенции преподавателей и студентов в экономическом вузе, (17), c. 20-26. 
2. Кештова, О .К., Обловацкая, И. Ф. \& Улитко, Е. Н. Практические приемы обучения говорению на английском языке студентов-экономистов. Гуманитарное образование в Экономическом вузе: материалы VI международной интернет-конференции (с. 45-48). 20.10-31.11, 2017 р, Москва, Росія: ФГБОУ ВПО «РЭУ им. Г.В. Плеханова».

3. Циликова, М. С. \& Аввакумова, И. В. (2016). Обучение на английском языке: за и против. Символ науки, (17), 221-225.

4. Чиханцова, Е. (2015). Роль иноязычной профессиональной коммуникативной компетенции во время овладения специальностью. Problemy profesjologii: Polrocznik poswiecony problemom rozwoju zawodowego czlowieka, (1), 173-183.

DOI 10.36074/25.10.2019.v2.23

\title{
РОЛЬ ПЕДАГОГІЧНОЇ ПРАКТИКИ У ПІДГОТОВЦІ МАЙБУТНЬОГО ВЧИТЕЛЯ
}

\author{
Євтух Микола Борисович \\ дійсний член (академік) НАПН України, д-р. пед. наук, професор \\ Інститут педагогіки НАПН України
}

УКРAÏHA

Інтеграція освіти України в європейський освітній та науковий простір вимагає від учителя зміни методологічних засад педагогічної діяльності, професійної активності і мобільності, здатності до сприйняття інноваційного досвіду, рівня його професійної компетентності, загальної культури, педагогічної майстерності та постійного самовдосконалення. Сьогоднішня школа чекає вчителя нової формації, який опанував надбання загальної і професійної культури, з послідовним педагогічним мисленням, вільним від стереотипів минулого і політико-ідеологічного тиску.

У цьому контексті виняткова роль у підготовці такого вчителя належить педагогічній практиці, специфіка якої полягає в самостійному виконанні студентами - практикантами повноцінної профресійної навчально-виховної діяльності. Педагогічна практика - найефективніша форма підготовки вчителя до професійної діяльності, провідна ланка в системі озброєння майбутнього вчителя професійними уміннями та навичками, під час якої студент глибоко і повно осмислює вікові й індивідуально-психологічні особливості дітей та формує власні, особистісні якості, характер; волю, цілеспрямованість, організаторські здібності, витримку, такт, уміння будувати взаємостосунки 3 дітьми та батьками.

Оцінка професійної майстерності на рівні результативних показників вимагає від студентів володіння наступним: оцінювати реальний стан освіченості учнів, їх здатність до навчання, стан вихованості й схильності до виховання; застосовувати індивідуальний і диференційований підхід до них; визначити перспективу їх індивідуального подальшого просування, проникнення у внутрішній світ особистості вихованців, уміння, будувати плани роботи з урахуванням індивідуальних завдань розвитку учнів. 
Важливими прийомами активізації творчого мислення студентів у період проходження педагогічної практики $€$ система завдань, які стимулюють використання педагогічної теорії на практиці, а саме: наукове обгрунтування мети і структури уроку, теоретичне обгрунтування методів навчання, визначення мети виховного заходу, вибір методів для вивчення окремого учня, класного колективу тощо.

Під час проходження педагогічної практики студенти не лише виконують завдання з навчально-виховної роботи, передбачені чинними інструктивними документами, а й проводять певну науково-дослідну роботу згідно із завданням кафредр педагогіки, психології методики викладання дисциплін, узагальнюють передовий педагогічний досвід, здійснюють педагогічні експерименти, психолого-педагогічні спостереження за учнями, готують наукові реферати на актуальні педагогічні теми. Про результати проведеної роботи вони доповідають на методичних семінарах, підсумкових конференціях із педагогічної практики, у студентських наукових гуртках, на щорічних студентських наукових конференціях. На основі матеріалів проведеного дослідження студенти пишуть курсові та дипломні роботи

У процесі педагогічної практики у школі студенти допомагають класному керівникові у навчально-виховній роботі з учнями: перевіряють учнівські роботи, зошити і щоденники, підтримують зв'язки з батьками, беруть участь у репетиціях, пов'язаних із підготовкою до позакласних виховних заходів; готують дітей до участі у предметних та художніх олімпіадах; допомагають в оформленні класних куточків, випуску стіннівок; проводять із дітьми ігри, екскурсії, вечори, диспути на актуальні теми. Тобто все те, що сприяє формуванню найнеобхідніших навичок студентів. Необхідність вступати в контакт із дітьми створює основу для виникнення спектру емоцій. Систематичне ведення педагогічного щоденника, в якому фріксується вся проведена робота, привчає студента-практиканта до самоаналізу. У щоденниках записуються окремі спостереження за учнями, дається аналіз уроків, які вони відвідують, поруч з фрактами формуються певні висновки, узагальнення, ставляться відповідні завдання. Особливу увагу студентів під час практики звертаємо на загальний розвиток дітей (інтелектуальної, вольової, емоційної, мотиваційної сфер особистості, тощо). Тому практику потрібно планувати так, щоб студенти протягом всього періоду її проходження працювали в одній і тій же школі.

3 метою інтелектуального розвитку учнів націлюємо під час практики студентів на інтенсивне формування на уроці педагогічних умінь: порівнювати, узагальнювати, класифікувати, знаходити аналогії, вміти виділяти головне тощо. Формування саме цих умінь, а також навчально-пізнавальних, пошуково-інформаційних студенти повинні проводити цілеспрямовано, послідовно, спираючись на певний досвід учня, включаючи всіх без винятку школярів, закріплюючи та розвиваючи ці уміння на кожному уроці. На основі науково-методичних рекомендацій по формуванню активної навчальної діяльності учнів, які були одержані під час лекційних, семінарських та практичних занять, студенти повинні чітко визначати для себе раціональні напрями роботи по оволодінню кожним умінням.

Спостерігаючи за студентами на уроках, аналізуючи їх, ми особливу увагу звертаємо на те, щоб студенти не тільки відбирали зміст навчального матеріалу, відповідно поставленій меті та дидактичним завданням, але й 
постійно намагалися його актуалізувати, пов'язати з оточуючим життям, зробити його зрозумілим, цікавим для учнів, що в значній мірі сприятиме пізнавальному інтересу дітей не тільки до вивчення окремого предмета, але й до процесу навчання в цілому. Навчаючи студентів, не слід забувати і про такий важливий компонент творчої лабораторії вчителя як наукову організацію навчальної праці. I тут мають значення умови, в яких працюють студенти під час проходження педагогічної практики.

Більшість шкіл, в яких проходять практику студенти, мають досить обладнані кабінети в яких $€$ і дидактичний матеріал, підготовлений вчителем разом з учнями, наочні посібники, аудіовізуальні засоби навчання, стенди підібрана спеціалізована література для вчителя, невелика бібліотека для учнів. I важливо навчити студентів правильно і ефективно використовувати можливості кабінету, увесь його арсенал, відібрати з усього, що має під рукою вчитель саме необхідне, виходячи з вимог доцільності використання того чи іншого матеріалу, засобів навчання саме на цьому уроці.

Становленню особистості вчителя має значення не тільки безпосередній досвід, яким володіє студент при підготовці та проведенні уроків, але й опосередкований, який поступово накопичується в результаті спостережень за роботою вчителів школи, своїх товаришів. Тому дуже важлива активність студентів під час аналізу своїх уроків, уроків, які вони спостерігали в школі (вчителів, студентів), виховних заходів.

Виходячи із цього необхідно розробити основні критерії, за якими кожен студент може охарактеризувати діяльність учителя та учнів: освітня, розвиваюча, виховуюча, контролююча та організуюча роль уроку; відбір змісту навчального матеріалу у відповідності з метою уроку, вимогами навчальної програми, особливостями класу; структура уроку, оптимальний зв'язок його етапів між собою, чіткий розподіл часу на різні види роботи, оптимальне використання, поєднання різних методів, форм і засобів навчання та їх результативність; індивідуальний підхід до учнів в процесі навчання, дотримання гігієнічних вимог; елементи новизни у змісті навчального матеріалу, структурі уроку, організації процесу навчання, методах, формах та засобах навчання, а також в кінці дати певні висновки щодо проведеного уроку, уроку вчителя, своїх товаришів.

Справжнім учителем стане із студентів той, хто поєднує в собі психологопедагогічні і спеціальні знання, педагогічну творчість, імпровізацію. Але при підготовці вчителя ми недостатньо звертаємо на це увагу, хоч кожний урок, виховна година повинні бути цікавими, оригінальними, враховувати особливості учнів класу, їх підготовленість, відношення учнів до теми уроку, виховного заходу, педагогічній ситуації, яка складається на уроці або під час проведення заходу. Важливо, щоб практика не зводилась лише до копіювання роботи тих чи інших вчителів, а грунтувалася на закріпленні і розвитку вмінь вести самостійні пошуки рішень педагогічних завдань на основі знань і умінь, які вони одержали в університеті в процесі вивчення психолого-педагогічних дисциплін.

Значна частина проблем, яких зазнають студенти, пов'язана 3 недостатністю досвіду і професійних умінь та навичок, а не з відсутністю природних здібностей. I все ж таки переважна більшість студентів отримують від практики значну користь щодо набуття педагогічного досвіду та знань 3 предмета. Варто зауважити, що практика допомагає студентам визначити, які 
риси, вміння та навички необхідні педагогу та накреслити шляхи самовдосконалення, переконання, що спеціальність вчителя, вихователя за своєю природою належить до найскладніших творчих професій. Як справедливо зазначається у Концепції національного виховання, педагог, вихователь $є$ довіреною особою суспільства, якій воно передає найдорожче і найцінніше - дітей, свою надію і своє майбутнє. Доля дітей - у руках педагога, його золотому серці, тому він має бути джерелом радісного пізнавального і морального зростання своїх вихованців.

\section{Список використаних джерел:}

1. Державна Національна програма «Освіта» (Україна XXI століття). (1997). Київ: Райдуга.

2. Державна програма «Вчитель». (2002). Освіта України, (27).

3. Бібік, Н. М. (ред.). (2018). Нова Українська школа: порадник для вчителя. Київ: Літера ЛтД.

4. Про вищу освіту (Закон України; втратив чинність). 2984-III. (2002). Вилучено 3 https://zakon.rada.gov.ua/laws/show/2984-14.

5. Про освіту (Закон України). https://zakon.rada.gov.ua/laws/show/2145-19.

2145-VIII.(2017). Вилучено

3

6. Національна доктрина розвитку освіти. (2002). Освіта, (26).

7. Галузинський, В. М. \& Євтух, М. Б. (1995). Основи педагогіки та психології вищої школи в Україні. Київ: ІНТЕЛ.

8. Євтух, М. Б., Лузік, Е. В., Ладогубець, Н. В. \& Ільіна, Т. В. (2014). Педагогічна психологія. Київ: Кондор-Видавництво.

9. Євтух, М. Б., Носко, М. О. \& Волощук, І. С. (2017). Психологія і педагогіка креативного розвитку обдарованої особистості. Київ-Чернігів: Десна Поліграф.

\section{САМОСТІЙНА РОБОТА У ПРОФЕСІЙНОМУ СТАНОВЛЕННІ МАЙБУТНЬОГО ВЧИТЕЛЯ МУЗИЧНОГО МИСТЕЦТВА}

\section{Корчагіна Ганна Сергіївна}

канд. пед. наук, доцент кафедри музично-інструментальної підготовки вчителя Харківський національний педагогічний університет ім. Г.С. Сковороди

УКРАÏHA

Принципово важливою фрормою організації освітнього процесу інструментально-виконавської підготовки $€$ самостійна робота студента. При цьому виді самостійна роботи може бути різною як за формою, так і за змістом: робота над програмними музичними творами з урахуванням поставлених викладачем завдань, вивчення і засвоєння нового навчально-виконавського матеріалу на основі аналізу авторського тексту музичного твору, читання нотного тексту з листа, підбір музики по слуху, транспонування нотного тексту, вивчення теоретичної та науково - методичної літератури з питань виконавства та педагогіки, прослуховування аудіозаписів музичних творів та їх виконавський аналіз.

У цілому, самостійна робота студентів спрямована на поглиблення та закріплення отриманих знань, умінь і навичок, забезпечення взаємозв'язку 
теорії і практики. Вона орієнтована на розвиток професійного потенціалу, становлення особистісної методичної позиції, стимулювання творчих пошуків у галузі методичних знань, виконавської та дослідницької діяльності, розвиток ініціативи, самостійності та готовності до самореалізації. Кожен з учених музикантів ототожнює самостійність з різними сторонами багатогранної профрільної діяльності, а саме: з підвищенням тезауруса (М. Калашник, Г. Падалка); моделюванням діяльності (Н. Тимошенко); виконавською діяльністю (Н. Згурська, Т. Лізньова,); створенням моделі репертуарного блоку (С. Чабаєва) та ін.

Учений И. Кяйс виділяв два поняття «самостійність» і «самостійна робота» [2]. Поняття «самостійність» він розглядав ширше, ніж поняття «самостійна робота», яку він розумів як початкову сходинку. Перша сходинка - студент виконує поставлене викладачем навчальне завдання, але без будь-якої його допомоги. Другою сходинкою самостійної роботи Й. Кяйс уважав таку її організацію, в якій студент має можливість вибору навчального завдання із запропонованих викладачем. Третьою сходинкою $є$ можливість самостійно визначити мету виконання завдання, вибирати саме завдання і організувати власну діяльність, спрямовану на його виконання.

Видатний педагог-музикант Г. Нейгауз у своїй книзі «Об искусстве фортепианной игры» зазначає: «Одна з головних задач педагога - зробити як можна швидше і повніше так, аби бути непотрібним учню, тобто прищепити йому самостійність мислення, методи роботи самопізнання та вміння добиватися цілей, що звуться зрілістю, порогом, за яким починається майстерність» [3].

Л. Баренбойм у своїх працях указує, на те, що тільки в самостійних пошуках, самостійному зіставленні явищ, самостійному відборі та оцінці відбувається розвиток творчого мислення та уяви. До стимулювання самостійності він відносить такі чинники, як читання нот з аркуша, виховання волі та інтересу до музикування, робота над сучасним репертуаром, для виконання якого ще немає установлених норм та сфрормованих традицій, тому молодий виконавець змушений шукати своє трактування, своє тлумачення, свою інтерпретацію. [1].

Г. Ципін до головних ознак самостійності виконавця відносить готовність самостійно відшукувати ефективні шляхи в роботі, знаходити потрібні засоби втілення художнього задуму, уміння без сторонньої допомоги орієнтуватись у незнайомому музичному матеріалі, вірно розкодувати авторський текст, здатність критично оцінювати результати власної музично - виконавської діяльності [4].

Отже, проблема самостійної роботи студентів і сучасній педагогіці i методиці музичного виховання набула великого значення. Вдало організована самостійна робота дозволяє розвинути творчу активність, навчитись самостійно працювати, постійне самовдосконалюватись.

\section{Список використаних джерел:}

1. Barenboym, L. A. (1979). Put k muzitsirovaniyu. L.-M.: Muzyka.

2. Kyveryalg, A. A. (1971). Voprosy metodiki pedagogicheskikh issledovaniy (Ch. I-II). Tallinn.

3. Neygauz, G. G. (1988). Ob iskusstve fortepiannoy igry: zapiski pedagoga (5-e izd.). M.: Muzyka.

4. Tsypin, G. M. (1984). Obuchenie igre na fortepiano. M.: Prosveshchenie. 


\title{
СПЕЦИФІКА ЗАСТОСУВАННЯ ІНФОРМАЦІЙНО- КОМУНІКАЦІЙНИХ ТЕХНОЛОГІЙ ПРИ ОРГАНІЗАЦІЇ ОСВІТНЬОГО ПРОЦЕСУ
}

\author{
Корєхов Артем Олександрович \\ старший викладач кафедри технологічної та \\ професійної освіти і декоративного мистецтва \\ Хмельницький національний університет
}

УКРАÏHA

Підготовка високоякісних фахівців інженерних спеціальностей в даний час набуває особливої актуальності. Висока професійна майстерність, вміння самостійно приймати обґрунтовані та ефективні інженерні рішення нині час неможливо без оволодіння методами роботи з інформаційними ресурсами, прикладним програмним забезпеченням спеціального призначення. Спроби наблизити процес фрахового навчання у відповідності до реальних виробничих процесів в тій чи іншій галузі організовувались неодноразово. Ці спроби надзвичайно корисні, бо формували у викладачів та студентів інтерес до такого навчання. Але впровадження в навчальний процес лише окремих елементів виробничого циклу часом не приносило бажаних результатів, так як не було системної роботи, а відбувалась шаблонна імітація майбутньої діяльності.

Важливою обставиною, що обумовлює необхідність інтенсифікації даного педагогічного дослідження, є прискорений розвиток інформаційних систем і поява відповідних інженерних спеціальностей, обмеженість сировинних, енергетичних, економічних і людських ресурсів. Крім того, реалізація інженерних завдань вимагає спільної участі великої кількості різних фахівців, часто територіально віддалених один від одного. У такій ситуації важливим етапом, упевненого оволодіння роботою 3 спеціальним програмним забезпеченням та організації ефективної взаємодії фахівців, повинні бути поставлені системи комплексної взаємодії людських знань, вмінь та навиків 3 готовністю застосовувати інформаційні ресурси у професійній діяльності [1].

Терміни «обчислювальна машина», «обчислювальна система», «обчислювальна мережа» виросли зі свого дослівного тлумачення і все більше визначають широкий спектр технологій, що застосовуються у різних галузях суспільства. Означена термінологія протягом останнього етапу розвитку виконують не тільки обчислення, а перетворення інформації, накопичення, зберігання, організацію, тлумачення, тобто являють собою фактично інформаційні системи. Не винятком є освітній процес у закладах вищої освіти, адже освіта є тією рушійною силою, що змушує суспільство розвиватись. Для обчислювальної системи існують різні визначення: від набору пристроїв обробки даних (автоматизованих або автоматичних), від одиночного комп'ютера з його програмним забезпеченням, до сукупності кількох взаємозалежних обчислювачів з їх програмним забезпеченням і периферійним обладнанням, призначеним для збору, зберігання, обробки і розподілу інформації. 
Обчислювальна система - сукупність одного або більше комп'ютерів або процесорів, програмного забезпечення i периферійного обладнання, організована для спільного виконання інформаційно-обчислюваних процесів. Традиційно під час навчання приділяється спочатку увагу поняттю інформації, інформаційним, інформаційно-обчислювальним і обчислювальних систем, включаючи складні системи, які використовують майбутні випускники закладів вищої освіти у професійній діяльності.

Сучасна науково-технічна революція характеризується швидкими темпами зростанням соціального і економічного значення інформаційної діяльності, як засобу забезпечення наукової організації, контролю, управління і здійснення суспільного виробництва. Сформувалася і бурхливо розвивається особлива галузь, яка перебуває на самому вістрі науково-технічного прогресу. Інформація з філософрської точки зору - міра організації системи. Підвищення організованості і впорядкованості за рахунок залучення інфоомаційних систем або більш якісної інформації, нерідко стає більш важливим фактором розвитку виробництва, ніж залучення у виробництво додаткових обсягів праці, сировини, енергії. В першому випадку система буде розвиватися інтенсивно, а в другому, при залучені додаткових матеріальних ресурсів - екстенсивно. Використання інформаційних ресурсів у навчальному процесі при підготовці майбутніх бакалаврів автосправи підвищує якість управління навчальним процесом, веде до інтенсифікації його створює позитивну мотивацію для подальшого розвитку і опанування нових знань [2].

Необхідно подолати традиційні уявлення про те, що статистичне значення надається, перш за все, матеріальним ресурсам, і усвідомити, що інформація так само $є$ невід'ємною частиною технологічного процесу виробництва, освітнього процесу. Настав час, коли інформація стала таким же важливим виробничим ресурсом, як матеріал і енергія, таким же основним економічним ресурсом науково-технічного потенціалу, як технічні, трудові та фрінансові ресурси. До інформації повинні бути сформульовані ті ж показники і критерії оцінки, розроблені такі ж прийоми і методи управління, що і до ресурсів і елементів процесу виробництва. Складні мультимедійні комплекси систем забезпечення інформативності освіти - це системи, що містять кілька однакових або різних, відносно самостійних комп'ютерів, пов'язаних між собою через пристрій обміну інформацією, зокрема по каналах зв'язку та комплекс додаткового обладнання, що реалізує наочні елементи навчання. До складу таких систем, як правило, відноситься спеціалізоване програмне забезпечення, що реалізує специфіку навчання до відповідних спеціальностей.

Комбінування різних методів навчання, застосування інформаційнокомунікаційних технологій з вивчення окремих елементів фахових дисциплін, в основні освітнього процесу у закладах вищої освіти, забезпечують якісний розвиток науково-педагогічного складу, студентів, матеріально-технічної оснащеності.

\section{Список використаних джерел:}

1. Husieva, A. I. (2015). Informatsiina kultura yak element informatsiinoho suspilstva. [Information culture as an element of information society]. Science, technology, technology, education, health. 
Kharkiv. [in Ukrainian].

2. Dakhyn, A. N. (2004). Pedahohycheskoe modelyrovanye: sushchnost, affektyvnost y neopredelennost [Pedagogical modeling: essence, effectiveness and uncertainty]. Theory and practice of educational technology. Moscow. [in Russian].

\section{ФОРМУВАННЯ ЛЕКСИКО-НАРОДОЗНАВЧОЇ КОМПЕТЕНТНОСТІ МАЙБУТНЬОГО ВЧИТЕЛЯ ПОЧАТКОВОї ШКОЛИ}

Гуськова Аліна Валеріївна

студентка 42 групи спеціальності «Початкова освіта. Англійська мова» КВНЗ КОР «Богуславський гуманітарно-педагогічний коледж імені І. С. Нечуя - Левицького»

Науковий керівник: Берегеля Лариса Миколаївна спеціаліст вищої кваліфікаційної категорії, викладачметодист КВНЗ КОР «Богуславський гуманітарно-педагогічний коледж імені І. С. Нечуя - Левицького» УКРАÏHA

Формування інтелектуальної культури нації, духовного потенціалу народу, вихід вітчизняної науки, техніки і культури на світовий рівень - першочергове завдання реформування сучасної освіти в Україні.

Народознавча підготовка вчителя початкових класів передбачає формування в нього народознавчої компетентності: уміння використовувати особливості мовленнєвої поведінки у відповідних ситуаціях спілкування, забезпечувати формування культури спілкування, ознайомлення з нормами етикету, сформованість знань та умінь щодо правил ввічливості, вміння визначати акцент та діалектні особливості мовлення, уміння складати й презентувати усні відгуки про побачене, почуте, пережите тощо [4].

Дослідження, присвячені формуванню лексико-народознавчої компетентності майбутнього вчителя, представлені у працях таких науковців, як А. Богуш, М. Вашуленко, Н. Голуб, Р. Дружененко, В. Загороднова, Л. Кожуховська, Т. Левченко, Г. Максимчук та інших. Учені доводять, що з допомогою лексики народознавчого змісту людина прилучається до історії свого народу, його духовності, пізнає генетичний код своєї нації.

У психолого-педагогічній літературі наявні різноманітні трактування поняття «компетенція» та «компетентність». Насамперед звернімося дословникових джерел. Зауважимо, що більшість словників обмежуються дефініцією слова «компетентність» і «компетентний», а саме: «Компетентний - це той, хто має достатні знання у якій-небудь галузі, 3 чимось добре знайомий, кваліфікований; той, що володіє компетенцією [2].

На думку А. Богуш, компетенція є якісним продуктом сукупності знань, досвіду, умінь та здібностей, що сприяють ефективному вирішенню питання у певній 
діяльнісній сфрері. Вчена наголошує, що компетентність охоплює три аспекти: знання, вміння та навички [1].

Під лексико-народознавчою компетентністю майбутнього вчителя початкової школи Н. Ємельянова розуміє сукупність лінгвістичних, лінгводидактичних та народознавчих знань, умінь i навичок, що визначають професійну спрямованість педагогічної діяльності.

Лексична компетенція вчителя - це передусім багатство активного й пасивного словника, а також наявність лексики професійної спрямованості та адекватне ії̈ використання, наявність, влучність і точність уживання образних виразів експресивнозабарвленої лексики, приказок і прислів"їв [3].

На мою думку, народознавча компетентність - це, так зване озброєння педагога знаннями про народні свята, звичаї, обряди, обереги, символи та їх використання як у навчально-мовленнєвій діяльності, так і в повсякденному спілкуванні з дітьми.

\section{Список використаних джерел:}

1. Богуш, А.М. (2010) Українське народознавство в дошкільному закладі та у школі. Київ: Вища школа.

2. Яременко, В. \& Сліпушко, О. (уклад.). (2005). Новий тлумачний словник української мови в чотирьох томах. (Т. 2). Київ: Аконіт.

3. Оліфіренко, В. В., Оліфіренко, Т. В. \& Оліфіренко, Л. В., (авт.-уклад.). (2010). Енциклопедія українознавства для школярів і студентів. Донецьк: Сталкер.

4. Використання елементів народознавства на уроках у початкових класах. (2018). Вилучено 3 https://naurok.com.ual. 
NOTES 


\section{$\Lambda \mathrm{O}$}

COLLECTION OF SCIENTIFIC PAPERS

\section{WITH PROCEEDINGS OF THE INTERNATIONAL SCIENTIFIC AND PRACTICAL CONFERENCE \\ «SCIENTIFIC DISCOVERIES: PROJECTS, STRATEGIES AND DEVELOPMENT»}

October 25, 2019 • Edinburgh, Scotland, UK

\section{VOLUME 2}

English, Ukrainian and Russian

All papers have been reviewed

Organizing committee may not agree with the authors' point of view Authors are responsible for the correctness of the papers' text

Signed for publication 25.10.2019. Format $60 \times 84 / 16$.

Offset Paper. The headset is Arial. Digital printing.

Conventionally printed sheets 8,72 .

Circulation: 100 copies.

Printed from the finished original layout.

Contact details of the organizing committee:

21037, Ukraine, Vinnytsia, Zodchykh str. 18, office 81

NGO European Scientific Platform

Tel.: +380981948380; +380981956755

E-mail: info@ukrlogos.in.ua

URL: www.ukrlogos.in.ua 